\title{
O TABULEIRO DOS JOGOS QUE SE BIFURCAM: AS MANIFESTAÇÕES DO LABIRINTO NOS JOGOS ELETRÔNICOS.
}

Dissertação apresentada ao Programa de Pós-Graduação em Artes Visuais, Área de Concentração Poética Visuais, Linha de Pesquisa Multimeios, da Escola de Comunicação e Artes da Universidade de São Paulo, como exigência parcial para obtenção do Título de Mestre em Artes Visuais, sob a orientação da Profa. Dra. Sílvia Laurentiz. 

Banca Examinadora 



\section{Agradecimentos}

À minha orientadora, Silvia Laurentiz, pela atenção dedicada e pela liberdade proporcionada ao longo do desenvolvimento deste projeto.

À FAPESP, pelo suporte à esta pesquisa, ao Programa de Pós-Graduação em Artes Visuais da ECA/USP e aos meus professores e colegas.

A Gustavo Rinaldi, pela ilustração do site.

A Luis Gustavo, pela ajuda na diagramação da dissertação.

Aos artistas e professores Lucia Koch e Mário Ramiro, pelo apoio e estímulo à vinda para São Paulo.

A todos os meus amigos que me ajudaram, de inúmeras formas, na realização da dissertação, seja com a sugestão de importantes referências bibliográficas, jogos a serem pesquisados e comentários sobre os trabalhos, seja com a sua presença ao longo destes anos de trabalho.

À minha família. 



\section{Resumo}

Esta pesquisa tem como objeto de estudo principal as manifestações do labirinto nos jogos eletrônicos, dando continuidade às nossas pesquisas sobre o labirinto e à nossa produção artística em novas mídias. As investigações realizadas se deram em duas frentes, sendo uma teórica, onde fizemos uma revisão da bibliografia sobre o labirinto, com a finalidade de termos os subsídios necessários para analisar a presença do labirinto nos jogos eletrônicos. Esta análise se deu em termos espaciais e temporais, tomando a forma de dois capítulos da dissertação, tendo o apoio de estudos na área dos jogos eletrônicos e de referências da literatura e do cinema. Já na frente artística, realizamos nove trabalhos, empregando mídias digitais, que se relacionam, de alguma forma, com a temática desta pesquisa. Apresentamos estes trabalhos ao longo da dissertação, dedicando um breve texto a cada um deles, onde apontamos o diálogo entre eles e os jogos eletrônicos, assim como com referências artísticas, literárias, cinematográficas e teóricas.

Palavras-chave: labirinto, jogos eletrônicos, game art, artemídia, arte digital. 



\begin{abstract}
This research is concerned with the ocurrences of labyrinths in electronic games, continuing our studies related to labyrinths and our artistic work in new media. The work done comprises two parts; the first one theoretical, where we revised selected references about the labyrinth, aiming to collect elements to analyse the ocurrences of labyrinths in electronic games. This analysis was performed in spacial and temporal terms, comprising two chapters of this dissertation, with the support of studies related to electronic games and literary and cinematographical references. In the artistic part, we developed nine works, using digital media, that are related, somehow, with the subject of this reasearch. These works are introduced along the dissertation, with a short text about each one, where we evidence the dialog between them and electronic games, as well as with artistic, literary, cinematographical and theoretical references.
\end{abstract}

Keywords: labyrinth, games, game art, new media arts, digital arts. 



\section{Sumário}

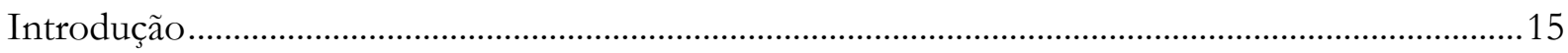

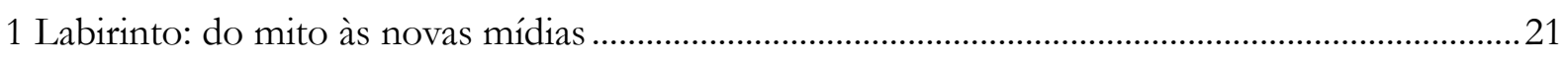

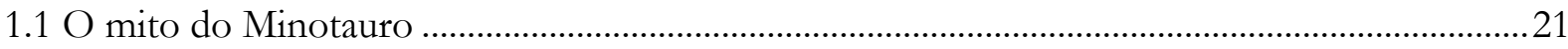

1.2 Aspectos simbólicos e significados atribuídos ao labirinto .............................................................22

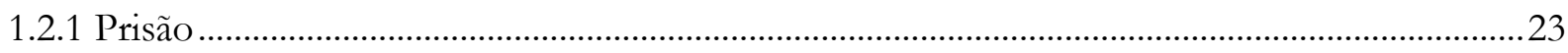

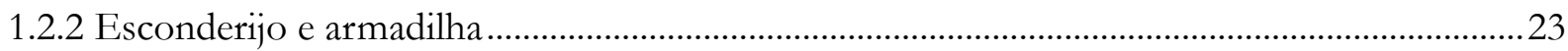

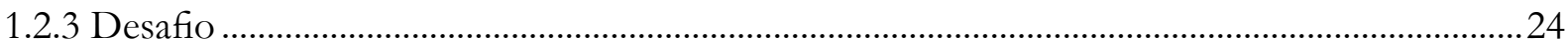

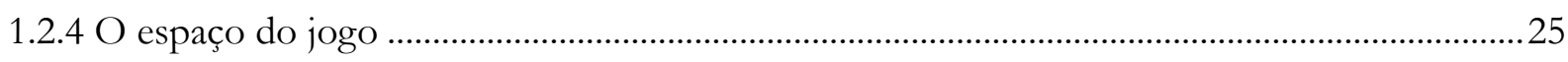

1.2.5 Percurso com obstáculos e o caminho para Jerusalém..................................................................26

1.2.6 Rituais de iniciação, simbolismo do centro e processos de auto-conhecimento .......................2

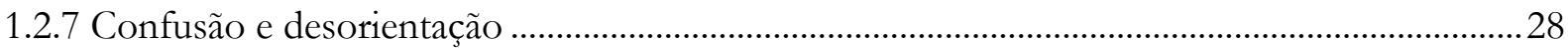

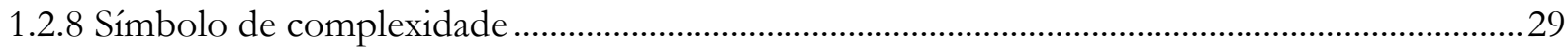

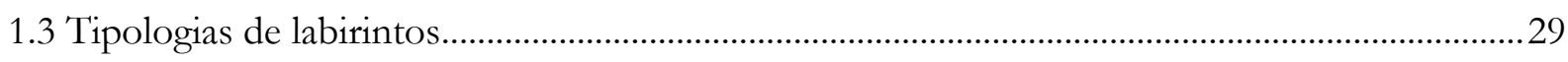

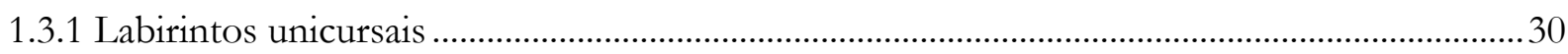

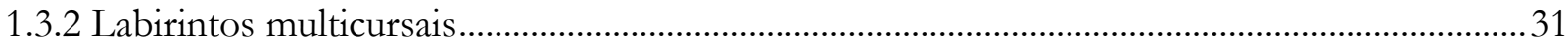

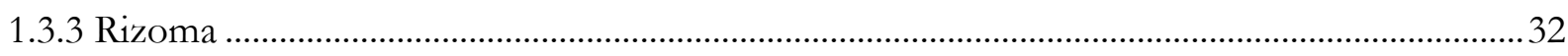

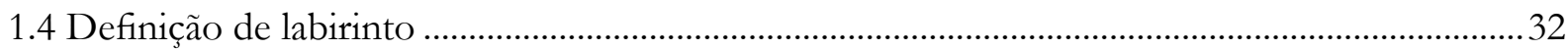

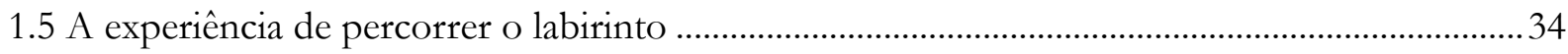

1.6 A associação entre labirintos e novas mídias...................................................................................... 36

A Para desenhar com os olhos / Para percorrer com os olhos.......................................................... 41

2 Manifestações espaciais do labirinto nos jogos eletrônicos ................................................................ 45

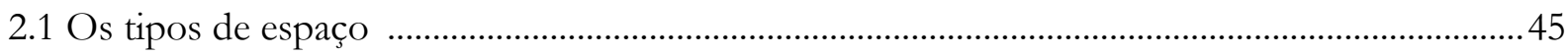

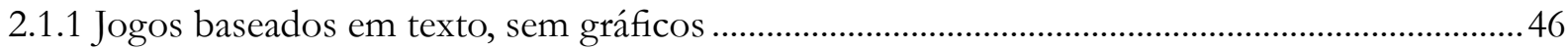

2.1.2 Jogos com espaço restrito às dimensões da tela ............................................................................. 49

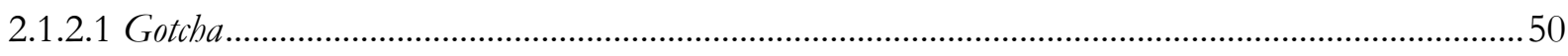

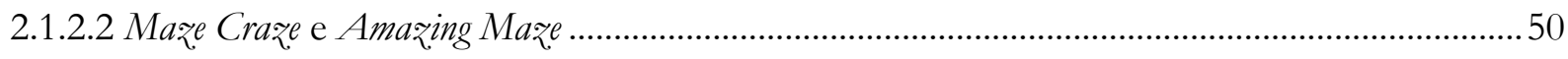

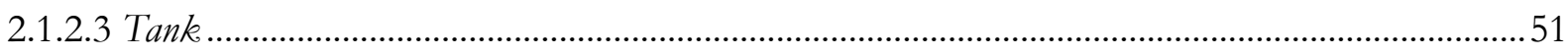

2.1.2.4 Dig D 
2.1.3 Jogos com rolagem em um eixo .............................................................................................5

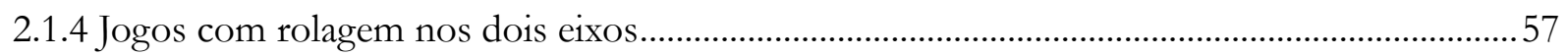

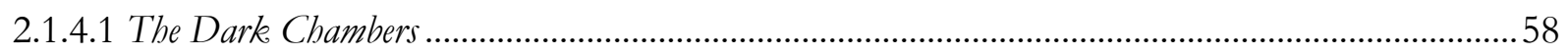

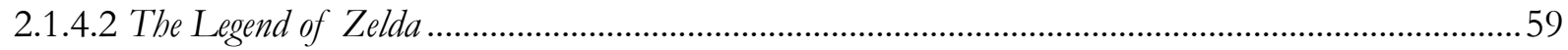

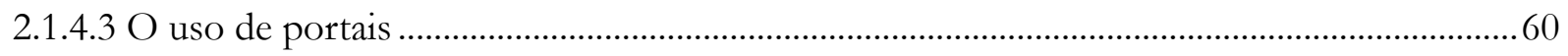

2.1.5 Espaços adjacentes, exibidos um de cada vez ..............................................................................60

2.1.6 Jogos com rolagem horizontal, com múltiplos planos ...........................................................63

2.1.7 Jogos como movimento no eixo Z (para dentro e para fora da tela) ..........................................65

2.1.8 Diversos espaços, não adjacentes, exibidos simultaneamente …………………………….......66

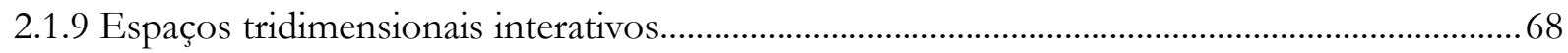

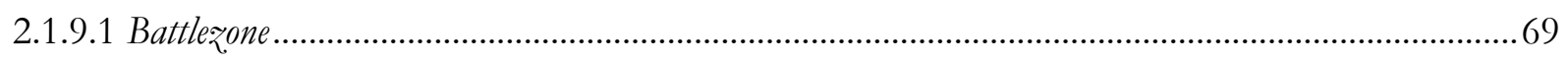

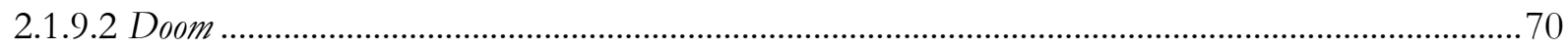

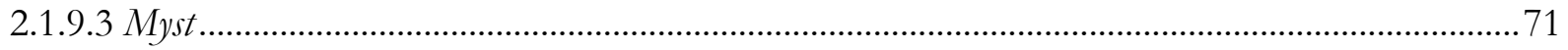

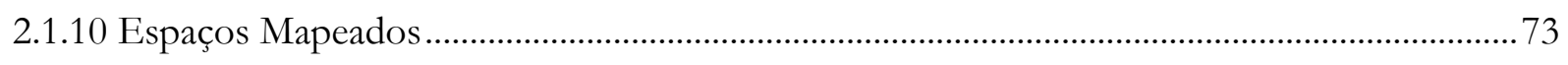

2.1.11 Jogos que utilizam o espaço urbano ........................................................................................... 74

2.1.12 A Internet como espaço do jogo .............................................................................................

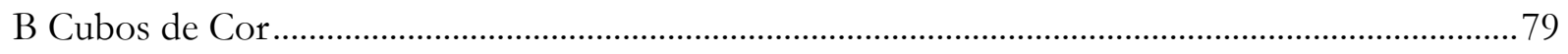

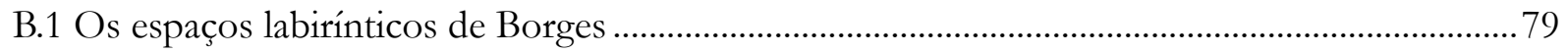

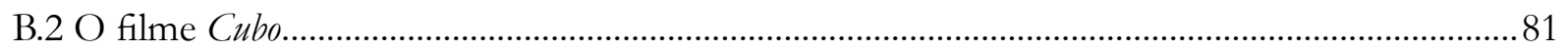

B.3 A série Homenagem ao Quadrado, de Josef Albers.......................................................................... 83

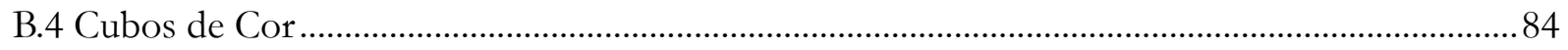

C First Person Movements................................................................................................................. 91

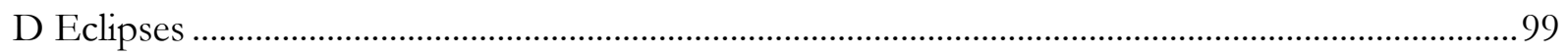

3 Labirintos temporais: o tempo nos jogos eletrônicos e algumas experiências temporais em outras mídias

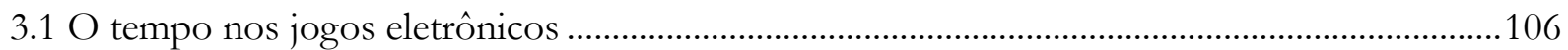

3.2 O tempo das múltiplas sessões de jogo e a possibilidade de salvá-lo............................................109

3.3 Outras possibilidades de formas temporais................................................................................. 109 
3.3.1 Os múltiplos desdobramentos possíveis de uma mesma narrativa.

3.3.2 O tempo das inúmeras tentativas de jogo ................................................................................114

3.3.3 O não conseguir sair do mesmo momento / lugar...................................................................117

E O tabuleiro dos jogos que se bifurcam........................................................................................123

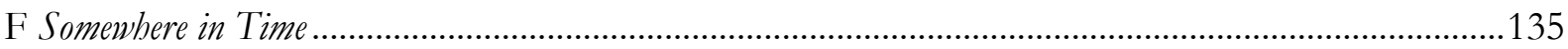

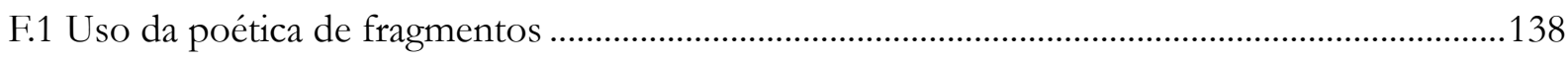

F.2 O filme Somewhere in Time e a espacialização do tempo................................................................140

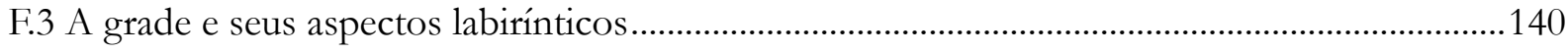

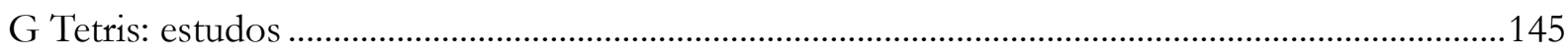

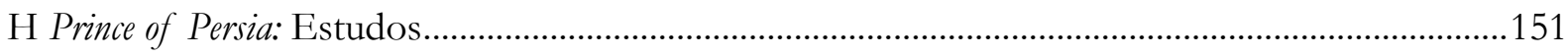

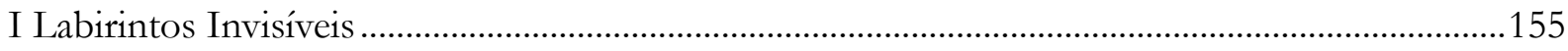

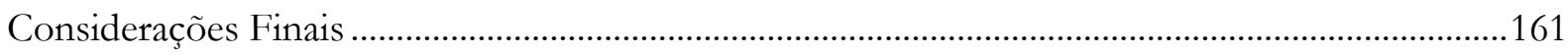

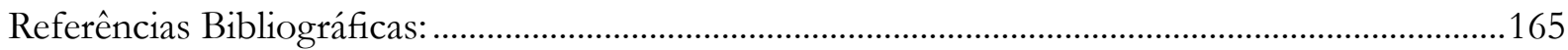

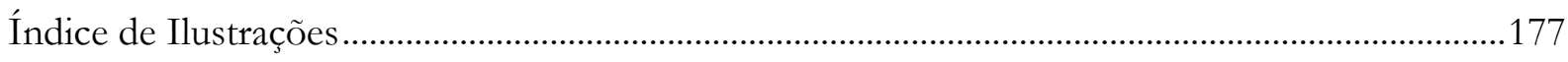

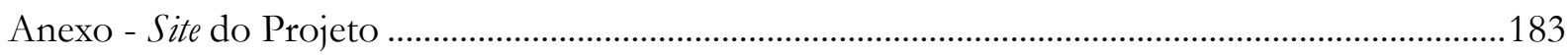





\section{Introdução}

Moedas cretenses, igrejas medievais e jardins ingleses foram alguns dos lugares onde o labirinto se manifestou ao longo da História. Dando continuidade às nossas pesquisas sobre o labirinto e à nossa produção artística em novas mídias, esta dissertação se volta a uma das ocorrências mais recentes do labirinto: os jogos eletrônicos. Antes de apresentar o trabalho realizado, faremos uma breve revisão de nosso percurso, para que o leitor possa compreender as nossas escolhas ao definir o objeto de estudo desta dissertação.

No contexto de nossa formação acadêmica e artística, que se deu principalmente no curso de graduação em Artes Plásticas, no Instituto de Artes da Universidade Federal do Rio Grande do Sul, em Porto Alegre (1998-2004), o interesse pelo labirinto e pelo universo do jogo se manifestou antes do envolvimento com os jogos eletrônicos. Nos dedicamos a estudos sobre o jogo e o labirinto, assim como a exercícios práticos envolvendo os mesmos, antes de realizar as primeiras experiências com as mídias eletrônicas e com as possibilidades de explorações artísticas oferecidas por elas. Tais exercícios foram realizados nas disciplinas que são familiares à grande maioria dos cursos de graduação em artes plásticas: iniciação às principais técnicas artísticas, estudos de teorias da percepção, história e teoria da arte, entre outras.

No terceiro ano de graduação, recebemos uma bolsa de iniciação científica para trabalhar em um projeto de pesquisa relacionado à informática na educação. O nosso contato com o processo de produção em mídias eletrônicas despertou a curiosidade em saber o que estaria sendo feito, no campo artístico, com essas mídias. Isso fez com que estudássemos, num primeiro momento, a produção de net arte ${ }^{1}$ realizada na época, e, depois, num escopo mais amplo, a produção artística envolvendo as novas mídias.

Paralelamente, demos início às nossas primeiras experiências de uso artístico da Internet. Nestes primeiros trabalhos, o labirinto sempre foi um dos elementos principais. Com a descoberta de trabalhos artísticos que exploravam o universo dos jogos eletrônicos, identificamos aquele que, ainda hoje, é um dos principais jogos associados ao labirinto: o jogo PacMan, criado em 1980 pela Namco, empresa japonesa de videogames (KENT, 2001, p. 142). Este jogo motivou a realização de

1 Arte desenvolvida especificamente para a Internet. Para maiores informações sobre a net arte, ver (PRADO, 2003), (GREENE, 2004) e o trabalho desenvolvido pelo grupo de pesquisa net art: perspectivas criativas e críticas, http:// netart. incubadora.fapesp.br/, coordenados pelos professores Giselle Beiguelman e Marcus Bastos. 
uma série de trabalhos, inclusive de nosso projeto de graduação, intitulado PacMan e o Minotauro, (2004) composto por um conjunto de trabalhos envolvendo os dois personagens ${ }^{2}$. A relação proposta entre eles começava pelo fato ambos serem habitantes do labirinto, o que nos permitiu aliar elementos mitológicos a elementos dos jogos eletrônicos.

Abaixo, apresentamos algumas imagens dos trabalhos que compõem o projeto PacMan e o

\section{Minotauro:}

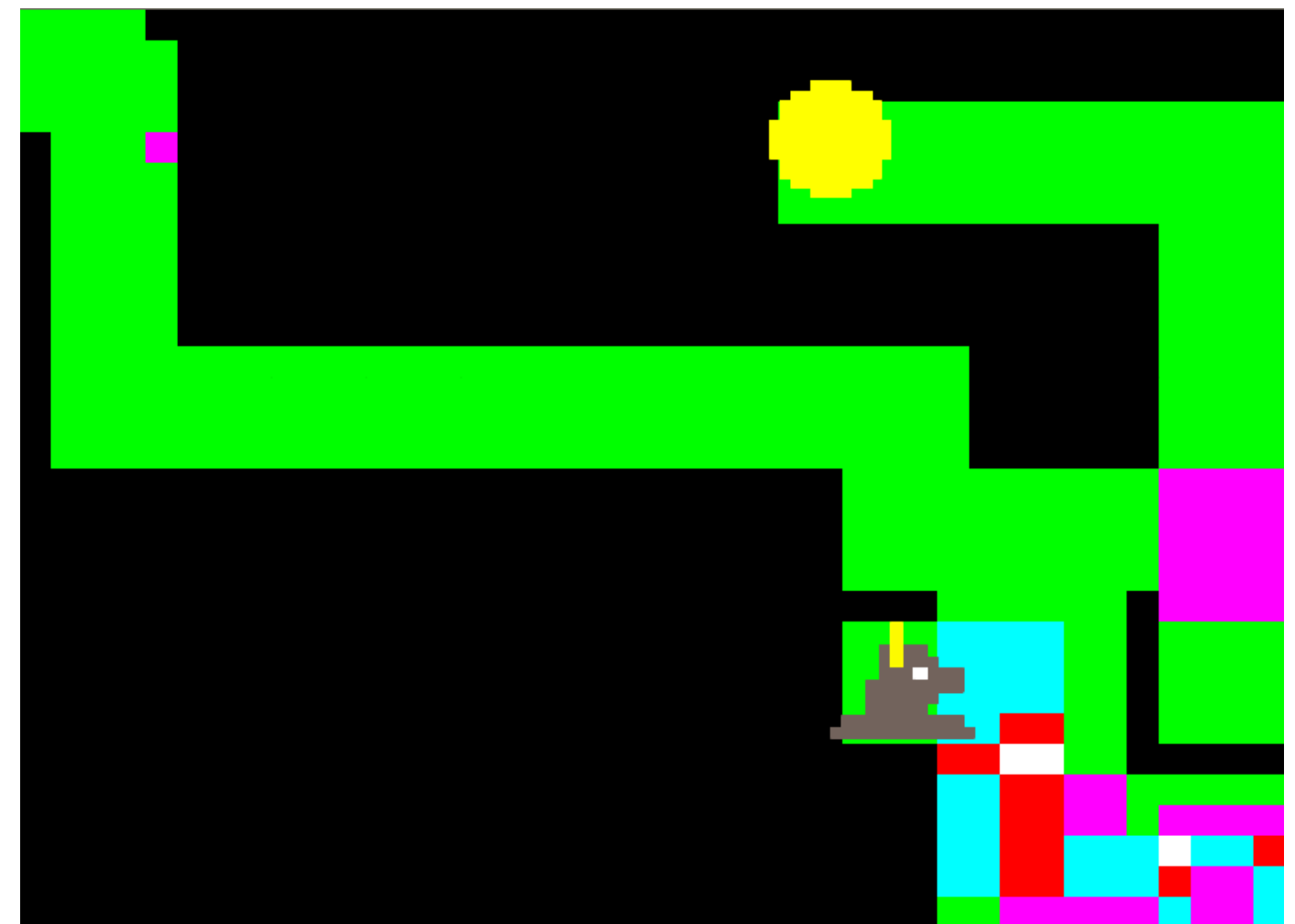

Ilustração 1. PacManDRAW!

2 http://www.andreithomaz.com/arte/pacman_minotauro/ 


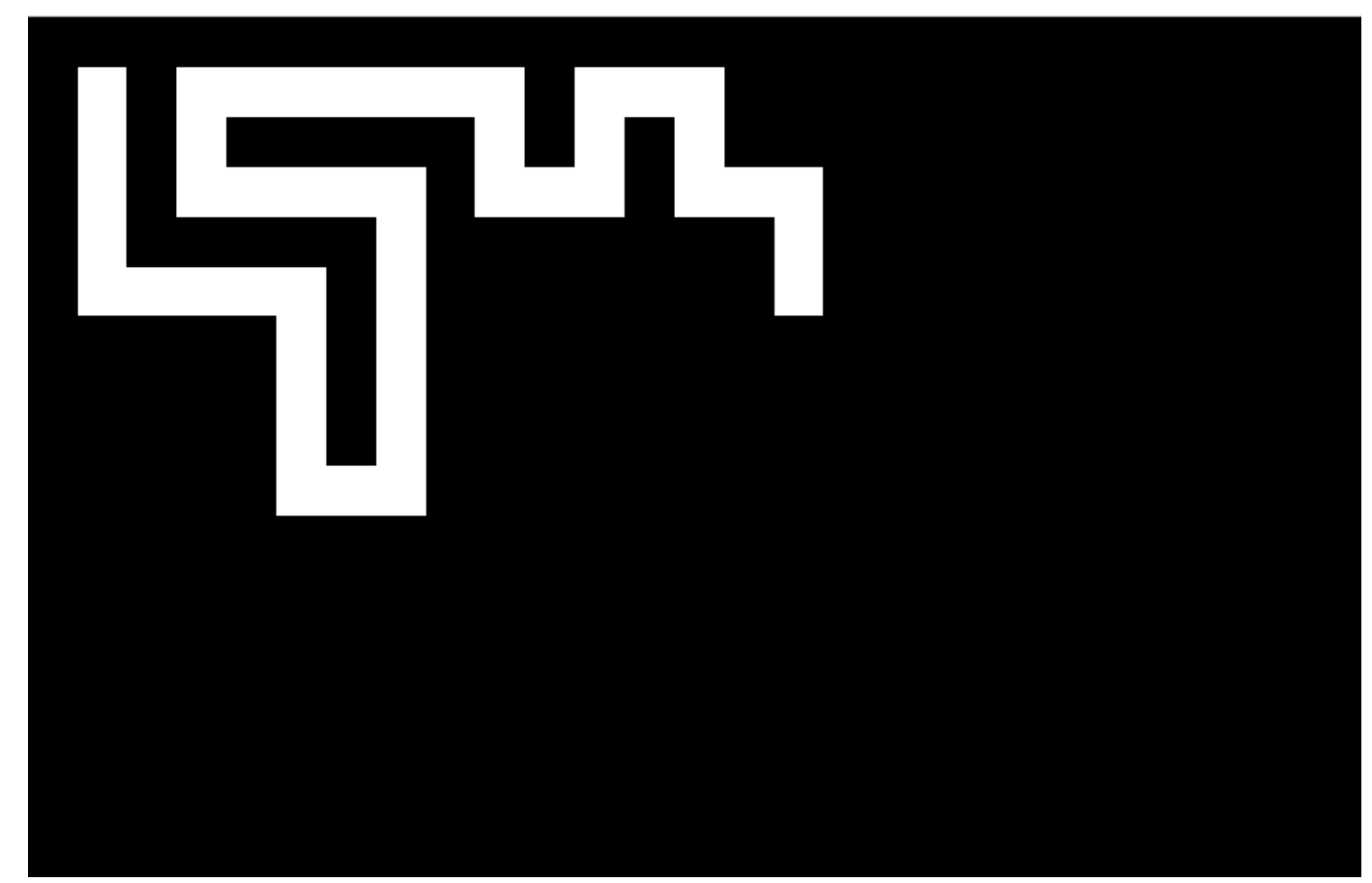

Ilustração 2. Dédalo e Ariadne.

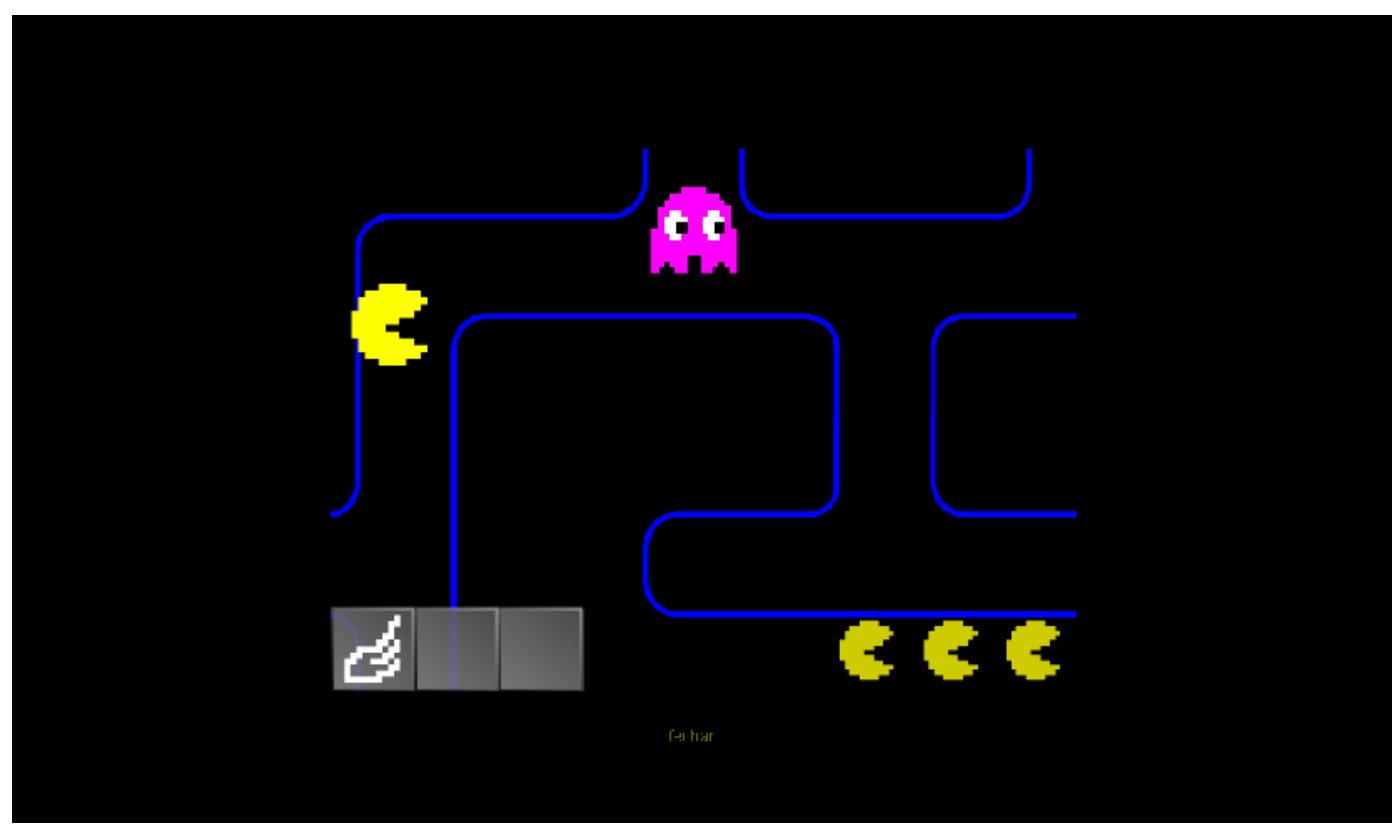

Ilustração 3. Primeira etapa de PacMan e o Minotauro.

Desta forma, o jogo PacMan atuou como importante catalisador, ao nos permitir reunir os nossos principais interesses artísticos e acadêmicos: os jogos, tanto tradicionais quanto eletrônicos, o labirinto e as novas mídias. 


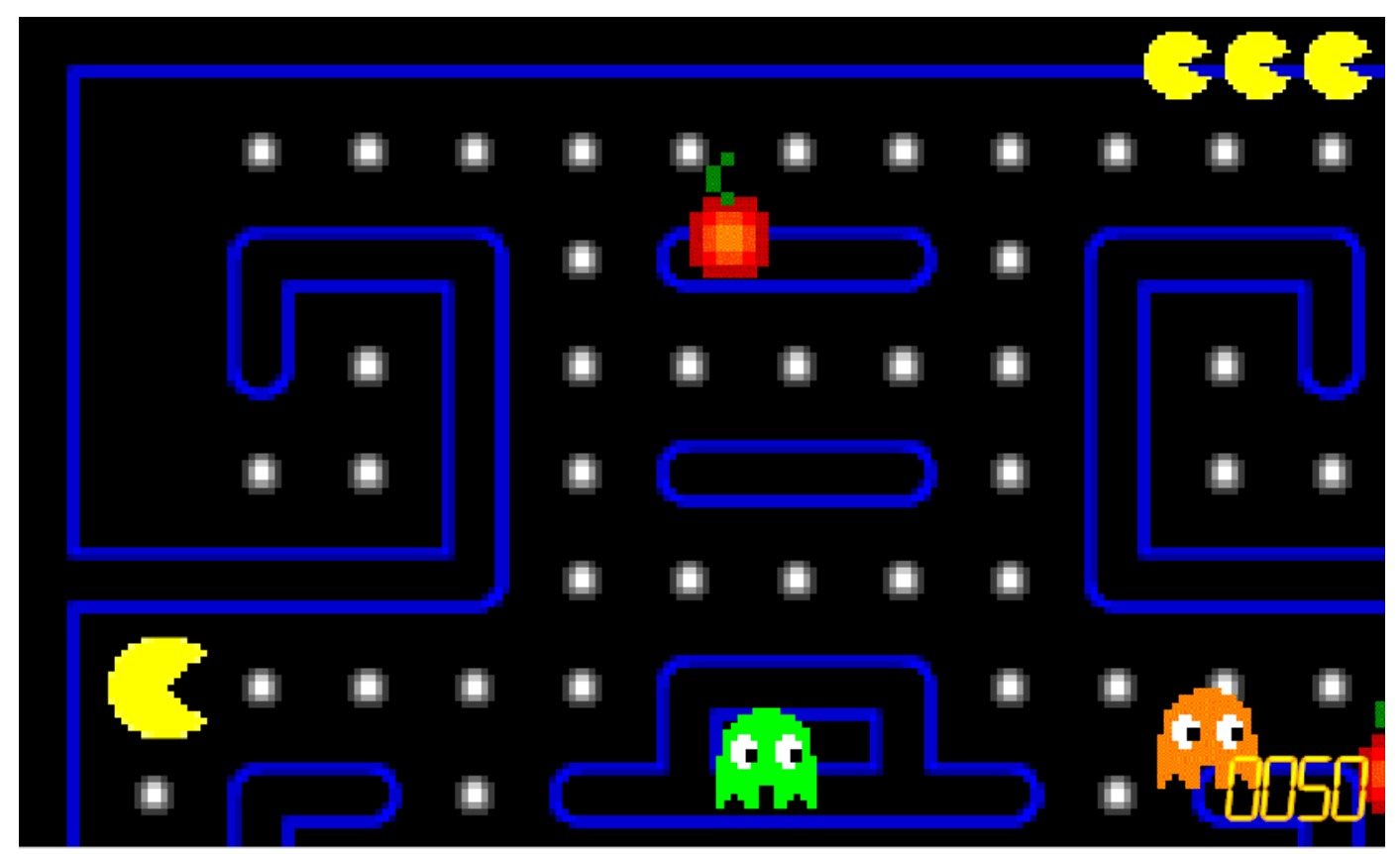

Ilustração 4. PacMan 1.0, trabalho desenvolvido entre 2002 e 2003.

Este processo de pesquisa sobre o labirinto nos jogos eletrônicos, focada num jogo específico, nos fez reunir um volume considerável de estudos teóricos e referências de jogos e trabalhos artísticos, permitindo vislumbrar a possibilidade e a necessidade de realizar um estudo de maior fôlego. Um estudo onde pudéssemos nos debruçar sobre o farto material que estávamos reunindo, e que poderia justificar o ingresso num curso de pós-graduação. Foi este processo que nos motivou a cursar o mestrado em Artes Visuais e a dar forma ao projeto de pesquisa desenvolvido no Programa de Pós-Graduação em Artes Visuais da ECA/USP, sob a orientação da Prof. Dra. Silvia Laurentiz.

O trabalho que realizamos pode ser dividido em duas frentes principais. A primeira, de cunho teórico, foi o estudo e a análise da presença do labirinto nos jogos eletrônicos. Não realizamos tal etapa de forma desinteressada; seu objetivo principal foi o de gerar elementos e subsídios que nos motivassem a produzir trabalhos artísticos envolvendo as manifestações do labirinto que nós pesquisávamos e analisávamos. Estes trabalhos, os quais formam a segunda frente deste mestrado, deram continuidade à nossa produção artística.

Deste modo, o nosso trabalho estabelece relações com três campos - o labirinto, os jogos eletrônicos e a arte - tendo o labirinto como fio condutor. Cada um destes campos possui a sua própria complexidade, com estudos teóricos próprios e demais especificidades. A nosso favor, de- 
vemos observar que, além de se debruçarem sobre os três campos que dão origem a este trabalho, diversos autores estudados também propõem relações entre eles. Citaremos alguns, de modo não exaustivo. Encontramos no trabalho de Matteo Bittanti e Domenico Quaranta (2006) uma reunião de artistas cujas obras lidam, de alguma forma, com os jogos eletrônicos; Arlindo Machado (1997b) e Lucia Leão (2002, p. 29) nos permitiram identificar as primeiras manifestações do labirinto nos jogos eletrônicos; finalmente, Leão (2002) e Gustav Hocke (2005) nos trazem obras de arte e obras literárias onde eles apontam a presença do labirinto. O círculo de relações se fecha.

O labirinto é o tema do primeiro capítulo de nossa dissertação. Realizamos uma revisão da bibliografia existente sobre o assunto, finalizando-a com uma rápida apresentação dos trabalhos de Leão e Machado onde os autores propõem, separadamente, a presença do labirinto no universo das novas mídias, desenvolvendo tal relação em diferentes aspectos. Esta proposição está na gênese deste projeto de pesquisa, pois, em diversos momentos, os autores apontam os jogos eletrônicos como sendo um dos campos das novas mídias onde o labirinto pode ser reconhecido.

A seguir, nos voltamos diretamente para as manifestações do labirinto nos jogos eletrônicos, sem nos deter na história ${ }^{3}$ e na revisão dos estudos dedicados a estes jogos ${ }^{4}$. O estudo destas manifestações exigiu dois capítulos da dissertação. No capítulo dois, realizamos um estudo da presença do labirinto em termos espaciais. Esta etapa nos proporcionou um grande conjunto de jogos a serem analisados, assim como contou com um suporte teórico mais próximo à questão do que o terceiro e último capítulo. Neste, analisamos a relação entre o labirinto e os jogos eletrônicos do ponto de vista temporal. Aqui, os estudos voltados diretamente aos jogos eletrônicos nos foram pouco úteis, ao contrário do que ocorreu quando estudamos o espaço dos jogos. Foi necessário buscar referências, tanto teóricas quanto artísticas, nos campos da literatura e do cinema.

Os três capítulos desta dissertação são permeados com breves apresentações dos trabalhos artísticos desenvolvidos neste projeto. Diversos motivos nos levaram a esta opção. O primeiro foi a preservação da autonomia dos trabalhos artísticos em relação à pesquisa teórica. A pesquisa teórica gerou os estímulos a partir dos quais realizamos os trabalhos, mas estes não são demonstrações nem validações da pesquisa. Devido às especificidades da criação artística, não poderíamos consi-

3 Para um panorama da história dos jogos eletrônicos, recomendamos Kent (2001) e De Maria e Wilson (2003)

4 Para uma introdução a estas questões, ver, entre outros: Wolf (2002), Wolf e Perron (2003), Wardrip-Fruin e Harrigan (2004) e Raessens e Goldstein (2005). 
derar tal ponto de vista adequado. A realização dos mesmos é uma outra forma de pesquisa, que se nutriu e estimulou a pesquisa de cunho teórico, num processo de retro-alimentação; entretanto, cada processo possui as suas necessidades específicas, de modo que não pode estar subordinado ao outro.

O segundo motivo consiste na percepção de que a nossa produção artística não é o objeto de estudo desta pesquisa. Isto é, nós realizamos descrições dos trabalhos e dos respectivos processos de criação, analisando os elementos que foram fundamentais para a produção de cada trabalho, mas entendemos que não nos cabe analisá-los da mesma forma que um crítico, curador ou outro tipo de pesquisador o faria. Podemos analisar um trabalho em andamento para pensar em outras formas de resolvê-lo, ou nos deter sobre trabalhos realizados para refletir sobre futuros projetos, mas não podemos ter a pretensão de interpretá-los ou de legitimá-los. Assim, nos preocupamos em dar os elementos necessários para que o leitor compreenda a gênese dos trabalhos e possa, ele mesmo, avaliar as relações da produção artística desenvolvida com os nossos esforços teóricos. Apontamos algumas destas relações no texto, e sugerimos outras através da maneira como os capítulos foram distribuídos, mas mantivemos o cuidado de não cair no equívoco de tentar esgotar estas relações.

Nas considerações finais, lançamos um olhar global para o projeto, apontando para algumas questões que, do nosso ponto de vista, o atravessam e estão presentes em todas as suas etapas. Foi possível esboçar a forma como concebemos o labirinto e a experiência proporcionada pelas suas manifestações. Também procuramos entender quais as suas origens; isto é, que elementos autores, escritores, artistas e obras - atuaram em nossa formação de modo a influenciar a nossa concepção do labirinto. 


\section{Labirinto: do mito às novas mídias}

O propósito deste capitulo é revisar a bibliografia sobre o labirinto que dá suporte a esta dissertação, desenvolvendo as primeiras relações do labirinto com o universo dos jogos eletrônicos e com os trabalhos artísticos desenvolvidos ao longo deste trabalho de mestrado. Começaremos com aquele que é o mito mais popular relacionado ao labirinto, cujos personagens são o Minotauro, Teseu, Dédalo e Ariadne. Em seguida, relacionaremos as principais significações atribuídas ao mesmo, tendo como guia principal o estudo de Paolo Santarcangeli (1974) sobre o tema, abordando em especial as que consideramos mais pertinentes ao nosso trabalho. Deslocando o foco para os aspectos formais do labirinto, revisaremos alguns pesquisadores, com destaque para W. H. Matthews (1970) e Hermann Kern (2000), que se preocuparam em criar tipologias de labirintos e a mapear as suas características formais. Finalizaremos o capítulo com as pesquisas de Arlindo Machado e Lucia Leão sobre a presença do labirinto nas novas mídias.

\subsection{O mito do Minotauro}

O principal mito envolvendo o labirinto, no sentido de ser o mais conhecido na cultura ocidental, é a história protagonizada por Teseu, Ariadne, Dédalo e o Minotauro. Como todo mito grego, é possível encontrar diversas variantes do mesmo; fiquemos aqui com um resumo da descrição feita por Junito de Souza Brandão (1989). Numa disputa com seus dois irmãos, Minos recebe o apoio de Poseídon, e assim obtém o poder sobre Creta. Entretanto, Minos não cumpre a sua parte no acordo com Poseídon, que seria sacrificar o touro que o deus fizera sair do mar (o aparecimento do touro era a demonstração da predileção dos deuses por Minos). Como parte de sua vingança, Poseídon faz com que a esposa de Minos, Pasífae, apaixone-se pelo touro.

\footnotetext{
Sem saber como entregar-se ao animal, Pasífae recorreu às artes de Dédalo, que fabricou uma novilha de bronze tão perfeita, que conseguiu enganar o animal. Pasífae colocou-se dentro do simulacro e concebeu do touro um ser monstruoso, metade homem, metade touro, o Minotauro. Esse Dédalo era ateniense, da família real de Cécrops, e foi o mais famoso artista universal, arquiteto, escultor e inventor consumado. (...) Mestre de seu sobrinho Talos, começou a invejar-lhe o talento e no dia em que este, inspirando-se na queixada de uma serpente, criou a serra, Dédalo o lançou do alto da Acrópole. A morte do jovem artista provocou o exílio do tio na Ilha de Creta. Acolhido por Minos, tornouse o arquiteto oficial do rei e, a pedido deste, construiu o célebre Labirinto, o grandioso palácio de Cnossos, com um emaranhado tal de quartos, salas e corredores, que somente Dédalo seria capaz, lá entrando, de encontrar o caminho de volta. Pois bem, foi nesse
} 
labirinto que Minos colocou o monstruoso Minotauro, que era, por sinal, alimentado com carne humana.

Ora, se o rei já estava profundamente agastado com seu arquiteto, por haver construído o simulacro da novilha, estratagema através do qual sua mulher fora possuída pelo Touro, ficou colérico ao saber que Dédalo havia também planejado, com Ariadne, a libertação de Teseu, filho de Egeu, rei de Atenas. É que, com a morte de Androgeu, filho de Minos, morte essa atribuída indiretamente a Egeu, que, invejoso das vitórias do jovem cretense nos jogos por aquele mandados celebrar em Atenas, enviara o atleta para combater o Touro de Maratona, onde perecera, eclodiu uma guerra longa e penosa entre Creta e Atenas. Como a luta se prolongasse e uma peste (pedido de Minos a Zeus) assolasse Atenas, Minos concordou em retirar-se, desde que, de nove em nove anos, lhe fossem enviados sete rapazes e sete moças, que seriam lançados no Labirinto, para servirem de pasto ao Minotauro. Teseu se prontificou a seguir para Creta com as outras treze vítimas, porque, sendo já a terceira vez que se ia pagar o terrível tributo ao rei de Creta, os atenienses começavam a irritar-se contra seu rei. Lá chegando, foi instruído por Ariadne, que por ele se apaixonara, como se aproximar do monstro e feri-lo. Deu-lhe ainda a jovem princesa, a conselho de Dédalo, um fio condutor, para que, após a vitória sobre o monstro, pudesse sair da formidável teia de caminhos tortuosos de que era constituído o Labirinto. Livre deste e do Minotauro, Teseu fugiu com seus companheiros, levando consigo Ariadne (...). Louco de ódio pelo acontecido, Minos descarregou sua ira sobre Dédalo e o prendeu no Labirinto com o filho Ícaro, que tivera de uma escrava do palácio, chamada Náucrates. Dédalo, todavia, facilmente encontrou o caminho de saída e, tendo engenhosamente fabricado para si e para o filho dois pares de asas de penas, presas aos ombros com cera, voou pelo vasto céu, em companhia de Ícaro, a quem recomendara que não voasse muito alto, porque o sol derreteria a cera, nem muito baixo, porque a umidade tornaria as penas assaz pesadas. O menino, no entanto, não resistindo ao impulso de se aproximar do céu, subiu demasiadamente. Ao chegar perto do sol, a cera fundiu-se, destacaram-se as penas e Ícaro caiu no mar Egeu, que, daí por diante, passou a chamar-se Mar de Ícaro.

(BRANDÃO, 1989, pp. 61-63)

Dentro deste projeto, desenvolvemos apenas um trabalho artístico relacionado a um mito envolvendo o labirinto, sendo que trata-se de uma narrativa distinta do mito grego, analisada a seguir, ao tratarmos do labirinto enquanto desafio página 24. Por isso, não citaremos os demais mitos e narrativas envolvendo o labirinto; gostaríamos de remeter o leitor interessado ao estudo efetuado por Santarcangeli (1974), O Livro dos Labirintos. Nele, o autor se preocupou principalmente com os aspectos simbólicos e com os significados atribuídos ao labirinto, em diversas narrativas e manifestações do mesmo. Como exemplos da pesquisa de Santarcangeli, colocamos a análise da presença, implícita ou explícita, do labirinto em mitos de povos da Oceania e da Babilônia, assim como em crenças, de diversos povos, sobre o destino da alma após a morte.

\subsection{Aspectos simbólicos e significados atribuídos ao labirinto}

Um dos pontos de convergência entre os autores por nós estudados é a multiplicidade de aspectos simbólicos e significados atribuídos ao labirinto, ao longo das suas inúmeras manifestações. Por ser este um assunto extremamente rico, e que já mereceu diversos estudos, nós apenas 
revisaremos aqui os significados e sentidos mais recorrentes do labirinto, dedicando maior atenção àqueles que, do nosso ponto de vista, estão mais presentes ao longo desta dissertação.

\subsubsection{Prisão}

Se para o Minotauro o labirinto não é apenas uma prisão, pois pode ser visto também como esconderijo e casa - sendo este último aspecto desenvolvido por Jorge Luis Borges no conto $A$ casa de Astérion, em O Aleph (BORGES, 2008b, pp. 60-63) -, temos a prisão de forma mais explícita no momento em que Dédalo é encerrado na sua própria criação, junto com seu filho Ícaro. Poderíamos ver aqui uma relação com alguns jogos eletrônicos, onde encontramos espaços de onde o jogador deve se esforçar para sair o mais rápido possível. Entretanto, optamos por desenvolver esta relação sob o aspecto do desafio porque, na maior parte dos jogos, o espaço de jogo é mais do que uma prisão; é um tabuleiro, onde o jogador deve cumprir inúmeros objetivos, que vão além de sair do labirinto no qual se está.

\subsubsection{Esconderijo e armadilha}

Encontramos o labirinto sendo encarado como um esconderijo e como uma armadilha no conto Aben Hakam, o Bokari, morto em seu labirinto (BORGES, 2008b, pp. 111-121), onde Borges narra a história de Aben Hakam e do vizir que o traiu, chamado Said. Este rouba um tesouro de Aben Hakam mas, sem coragem de o matar, foge e constrói um labirinto, no qual passa a residir. Entretanto, Said se faz passar por Aben Hakam; apresenta-se com este nome na cidade onde se refugia, fazendo com que o labirinto por ele construído seja visto como um refúgio, um esconderijo. E é na troca de nome de Said que nós temos a transformação do esconderijo em armadilha: na verdade, o labirinto não é o refúgio de Aben Hakam, mas sim a armadilha que Said preparou para Aben Hakam. A estranha residência de Said gera rumores que se espalham e acabam por atrair a sua presa (a única pessoa que sabe da existência de Said e de sua verdadeira identidade), que é morta por Said dentro do labirinto. Este foge, levando o tesouro roubado de Aben Hakam.

Talvez pudéssemos ver o esconderijo e a armadilha como sendo casos do labirinto como 
um desafio (já que este é o aspecto que o labirinto assume para aquele que nele penetra em busca de sua presa), mas optamos por destacá-los em função da sua presença nos jogos eletrônicos por nós estudados. Como um dos casos mais evidentes, apresentamos o gênero denominado first person shooters, dos quais são representantes jogos como Quake, Doom e Wolfenstein. As características labirínticas dos espaços utilizados por estes jogos serão analisadas com maior atenção no próximo capítulo desta dissertação; por ora, vamos somente apontar as armadilhas e os esconderijos presentes neles.

O espaço destes jogos é constituído, majoritariamente, por corredores e espaços mais amplos, que denominaremos câmaras, sendo que a passagem de um corredor para uma câmara pode ser livre ou, então, bloqueada por uma porta. É aí que temos a armadilha mais comum nos first person shooters: câmaras repletas de adversários, que atacarão o jogador tão logo ele se aproxime. Usualmente, o jogador precisará "morrer" diversas vezes, até conhecer as principais armadilhas de cada nível de um jogo e conseguir passar incólume por elas.

Em relação ao esconderijo, este se manifesta principalmente quando joga-se no modo multiusuário. Isto ocorre porque a grande maioria dos inimigos do jogador, quando controladas pelo computador, não possui inteligência suficiente para persegui-lo; a sua ação fica restrita a um determinado espaço, só atacando quando o jogador aproxima-se. Já quando o inimigo é outro ser humano, será preciso fugir e esconder-se, a fim de, quem sabe, conseguir realizar uma emboscada.

\subsubsection{Desafio}

Para introduzir a idéia do labirinto como um desafio, vamos fazer referência a um mito oriundo da Ilha de Malekula, Oceania. Nele, os homens falecidos são submetidos, por um personagem feminino, a uma prova que consiste em reproduzir um desenho traçado sobre a areia. Tal desenho possui, de acordo com os pesquisadores nos quais Santarcangeli se baseia, traços labirínticos (SANTARCANGELI, 1974, p. 164-5).

Tanto no mito grego quanto no da ilha de Malekula temos o labirinto associado à idéia de desafio. Para Teseu, não basta enfrentar e vencer o Minotauro; é preciso fazer uso do fio de Ariadne e sair do labirinto. Já para o recém-falecido, segundo os Malekulas, é necessário ser capaz de repro- 
duzir o desenho feito pela guardiã do reino dos mortos na areia (LEÃO, 2005, p. 87).

Saindo dos mitos, encontramos a associação entre labirinto e desafio em Santarcangeli (1974, pp. 361-382), quando ele cita as experiências feitas com ratos em labirintos e com testes psicológicos que também fazem uso de labirintos; em Machado (1997b, p. 145) e em Leão (2002, p. 29), quando ambos apontam a presença de labirintos nos jogos eletrônicos:

Labirinto-maze, Final Fantasy e tantos outros jogos, reatualizam o prazer do enigma, do desafio intelectual. Exigem concentração, paciência, reflexão e muita perseverança. Assim, podemos ver que os bons títulos de videogame vão muito além das questões reducionistas que vêm sendo colocadas. O videogame é, portanto, uma celebração do labirinto, naquilo mais ancestral e mítico que o labirinto nos evoca. Perambular por espaços inusitados, contar com armas poderosíssimas, vencer monstros e dragões, solucionar enigmas obscuros e adivinhas: o videogame é uma brincadeira que simula e reconstrói a jornada mítica do herói.

(LEÃO, 2002, p. 30)

Consideramos que é a idéia de desafio que instaura a relação mais forte não apenas com os jogos eletrônicos, mas com o universo do jogo em geral. Escapar de uma prisão, orientar-se em meio a corredores e espaços dos quais não se possui um mapa, encontrar a saída antes do adversário, evitar as armadilhas colocadas ao longo do caminho, reunir informações esparsas e tentar criar um mapas e imagens globais; todos esses são problemas que precisam ser enfrentados pelo jogador, e que ajudam a estabelecer a relação entre o jogo e o labirinto.

O labirinto enquanto desafio também é um problema de ordem matemática. Em Pierre Rosensthiel (1988b) e em Ian Stewart (2008) encontramos sucintas revisões dos principais métodos de resolução de labirintos, bem como análises sobre a eficácia dos mesmos, do ponto de vista lógico-matemático. Como não chegamos a explorar tais métodos nos trabalhos desenvolvidos neste projeto, gostaríamos de remeter o leitor interessado a estas fontes.

\subsubsection{O espaço do jogo}

Um dos resultados da associação entre jogo e labirinto é a percepção de que, em alguns casos, o labirinto instaura o espaço do jogo, delimitando-o. É o que coloca Santarcangeli (1974, p. 232), referindo-se ao conhecido estudo de Johan Huizinga, Homo Ludens, onde este define as características essencias do jogo. Uma delas é a de que o jogo consiste em uma "evasão da vida real” (HUIZINGA, 2005, p. 11), distinguindo-se da vida "tanto pelo lugar quanto pela duração que 
ocupa" (idem, p. 12). Referindo-se especificamente ao espaço do jogo, ele afirma:

\begin{abstract}
A limitação no espaço é ainda mais flagrante do que a limitação no tempo. Todo jogo se processa e existe no interior de um campo previamente delimitado, de maneira material ou imaginária, deliberada ou espontânea. Tal como não há diferença formal entre o jogo e o culto, do mesmo modo o "lugar sagrado" não pode ser formalmente distinguido do terreno de jogo. A arena, a mesa de jogo, o círculo mágico, o templo, o palco, a tela, o campo de tênis, o tribunal etc., têm todos a forma e a função de terrenos de jogo, isto é, lugares proibidos, isolados, fechados, sagrados, em cujo interior se respeitam determinadas regras. Todos eles são mundos temporários dentro do mundo habitual, dedicados à prática de uma atividade especial.
\end{abstract}

(HUIZINGA, 2005, p. 13)

Muitos jogos eletrônicos utilizam espaços labirínticos como cenário; é o que estudaremos no capítulo seguinte, a partir da página 45. Neste ponto, gostaríamos apenas de indicar uma situação em que o labirinto não instaura um espaço de jogo, propriamente dito, mas de lazer. Estamos nos referindo a alguns dos labirintos construídos em jardins, que tornam-se espaços de entretenimento, à medida que os seus caminhos ganham estátuas, bancos e áreas de descanso. O exemplo mais citado em nossa bibliografia é o labirinto do Palácio de Versalhes, construído na segunda metade do século XVII. Nele,

a idéia não era problematizar, intrigar ou confundir seu visitante. O objetivo propulsor, que levou seu arquiteto a planejar alamedas de jardins, foi o de proporcionar divertimento. Para ressaltar ainda mais essa característica lúdica, seus recantos floridos contam com esculturas que representam cenas de fábulas de Esopo.

(LEÃO, 2002, p. 12)

1.2.5 Percurso com obstáculos e o caminho para Jerusalém

De acordo com Kern, labirintos têm sido construídos dentro de igrejas cristãs desde o século III, mas é a Idade Média o período no qual eles se tornam mais presentes nas igrejas (KERN, 2000, p. 143). Diversas hipóteses para o uso de labirintos em igrejas são apresentadas por Kern, Matthews e Santarcangeli, entre elas a de que os labirintos representariam a peregrinação a Jerusalém, ou, então, o caminho para a redenção. Esta segunda interpretação aproxima-se de um dos sentidos do labirinto aos quais Santarcangeli dedica maior atenção em seu estudo: a idéia de que o labirinto representaria a própria vida humana, na forma de um percurso cheio de obstáculos e de mudanças de direção, a fim de contorná-los (SANTARCANGELI, 1974, pp. 181-190). Retomaremos com maior atenção as interpretações dos labirintos presentes na igrejas no texto dedicado ao 
trabalho Para desenhar com os olhos / Para percorrer com os olhos, a partir da página 41, que utiliza o desenho do labirinto existente na Catedral de Chartres, França.

1.2.6 Rituais de iniciação, simbolismo do centro e processos de auto-conhecimento

Entre as interpretações do labirinto, Kern (2000, p. 30) declara preferir a tese de que ele simboliza ritos de iniciação, onde o centro guarda segredos que só são dignos daqueles que conseguem chegar até ele. $\mathrm{O}$ caminho percorrido no labirinto representaria, assim, as etapas de preparação daquele que protagoniza o processo de iniciação.

Esta hipótese é uma das mais presentes nos estudos do labirinto, e possui alguns desdobramentos. Um deles é a interpretação, seja do labirinto, seja de seu centro, como sendo uma espécie de morada do sagrado (LEÃO, 2002, p. 31). Outra, a qual Santarcangeli dedica certa atenção, é a visão da jornada rumo ao centro do labirinto como um processo de auto-conhecimento. É neste ponto que ele estabelece uma relação entre o espelho e o labirinto:

\begin{abstract}
Resumindo, no centro mesmo do segredo - seja templo ou labirinto - o homem encontra aquilo que quer encontrar. Com muita freqüência... encontra a si mesmo: gnôthi seautón! O conhecimento último é aquele de si mesmo, a compreensão do próprio eu, refletido em minha própria consciência. É essa a razão profunda da freqüente presença de um espelho, no fundo do labirinto; assim, depois de muito tempo percorrendo as curvas entrelaçadas do caminho, o homem descobre, quando atinge o objetivo das suas peregrinações, que o último mistério da sua busca, o deus absconditus - ou o monstro - é ele mesmo.

(SANTARCANGELI, 1974, p. 218. Tradução de Lourenço Dreyer; grifos do autor ${ }^{5}$ )
\end{abstract}

Transpondo a idéia de processo de auto-conhecimento para o universo dos jogos eletrônicos, enxergamos uma proximidade com o processo de conhecimento e domínio das regras do jogo pelo jogador. De acordo com Katie Salen e Eric Zimmerman (2004, p. 88), há uma diferença entre a forma como as regras são aprendidas e vivenciadas entre os jogos tradicionais e os jogos eletrônicos. Na grande maioria dos jogos tradicionais, é necessário que pelo menos um dos participantes conheça as regras do jogo. Já no caso dos jogos eletrônicos, é muito comum que o jogador inicie um jogo desconhecendo as suas regras; ele irá conhecê-las e dominá-las ao longo de inúmeras ses-

5 Texto da tradução francesa: Bref, l'homme trouve au centre des arcanes - temple ou labyrinthe - ce qu'il veut y trouver. Très souvent... il s'y trouve lui-même: gnôthi seautón! L'ultime connaissance est celle de soi-même, la compréhension du propre soi, réfléchi dans sa propre conscience. C'est la raison profonde de la présence fréquente d'un miroir, au fond du labyrinthe; ainsi l'homme qui a longtemps erré dans les enchevêtrements du chemin, découvre, lorsqu'il atteint finalement le but de ses pérégrinations, que l'ultime mystère de sa recherche, le deus absconditus ou le monstre c'est lui-même. 
sões de jogo. Junto com as regras, ele descobrirá e mapeará outros elementos do jogo: seus espaços, suas armadilhas e as estratégias necessárias para vencê-las. Assim, seu conhecimento sobre o jogo se amplia a cada sessão, permitindo que ele se aproxime cada vez mais da vitória.

\subsubsection{Confusão e desorientação}

De acordo com Kern (2000, p. 23), este é o sentido mais comum do termo labirinto: uma metáfora, "uma referência a uma situação confusa, difícil, desorientadora". É, na nossa opinião, a definição mais próxima do uso habitual (tal como o senso-comum o utiliza) do adjetivo labiríntico. Ainda segundo Kern, este uso metafórico pode ter sua origem na palavra maze (empregada por ele para denominar os labirintos de múltiplos caminhos, em oposição aos labirintos unicursais, para os quais ele reserva a palavra labyrinth), que se refere a "uma estrutura tortuosa que oferece ao caminhante inúmeros caminhos, com alguns levando a becos sem saída" (KERN, 2000, p. 23). Por sua vez, Leão (2002, p. 28) também relaciona este sentido do labirinto com a sua denominação em alemão, irrweg, cujo significado é “caminho errado".

Apesar deste ser o aspecto mais comumente associado ao labirinto, devemos observar que, em todas as análises sobre manifestações do labirinto, ou que utilizam o labirinto como chave para o estudo de algum campo ou fenômeno, ele é deixado de lado em prol dos outros sentidos que listamos neste capítulo: símbolo de ritos iniciáticos, signo de complexidade, desafio cognitivo e outros. Também consideramos que a idéia de confusão associada ao labirinto é pouco útil para a área de jogos eletrônicos: se um jogo não se configura como desafio, e sim como algo confuso ao usuário, isto significa que algo está errado, seja na interface do jogo, nas suas regras ou na falta de familiaridade com os jogos, por parte do jogador. Desenvolveremos, no terceiro capítulo, algumas considerações sobre o agenciamento e a indecibilidade nos jogos eletrônicos, com base, respectivamente, no trabalho de Janet Murray e de Aleph Einchemberg, a partir da página 119, mas, por enquanto, podemos adiantar que a confusão trabalha contra o agenciamento nos jogos; por este motivo, não daremos maior atenção a ela nesta dissertação. 


\subsubsection{Símbolo de complexidade}

$\mathrm{Na}$ contramão da idéia de confusão e desordem, temos a visão do labirinto com uma das figuras da complexidade. De acordo com esta visão, nele não há desordem propriamente dita, mas sim uma ordem “complicada ou oculta" (CALABRESE, 1987, p. 145). Este raciocínio pode ser encontrado em $A$ Idade Neobarroca de Omar Calabrese (1987, p. 145), em Leão (2005 e 2002) e em Machado (1997a e 1997b), e também podemos identificá-lo como sendo a base da aplicação do labirinto como chave para estudar as novas mídias, tal como o fazem Arlindo Machado e Lucia Leão em pesquisas que estudaremos com maior atenção a seguir.

Entendemos que nos jogos eletrônicos a idéia de labirinto como figura da complexidade se faz menos presente do que as manifestações do labirinto na forma de desafios cognitivos. Entretanto, a definição do labirinto como sendo a de uma situação onde há uma ordem que é "complicada ou oculta" foi muito importante para o desenvolvimento de alguns dos trabalhos artísticos que fazem parte deste trabalho de mestrado. Voltaremos a esta idéia nos textos que descrevem a concepção e a produção de cada trabalho, e que se encontram ao longo da dissertação.

\subsection{Tipologias de labirintos}

Para tratar deste tópico, nos baseamos em dois grandes estudos sobre o labirinto, executados por Matthews (1970) e Kern (2000). Ambos foram sistematizados, de forma bastante sucinta, por Lucia Leão, em A estética do labirinto (LEÃO, 2002, pp. 46-56), e trazem diversas categorias de labirintos, tais como labirintos encontrados em igrejas, labirintos construídos em jardins (em que as paredes são formadas por plantas podadas para ganhar tal aspecto) e os labirintos romanos, com inúmeros exemplos de cada categoria. Os dois estudos também dedicam grande atenção ao labirinto de Creta, associado ao Minotauro, e ao labirinto egípcio, que se mostram, assim, as construções labirínticas que maior atração exereceram sobre os historiadores, ao mesmo tempo em que estão cercadas por dúvidas sobre a sua real existência, bem como sobre sua localização exata e respectivos processos de destruição.

Neste capítulo, vamos nos limitar a apresentar os três grandes grupos de labirintos, conforme definidos por Leão a partir de Matthews e Kern, apresentando as ocorrências de cada grupo dentre os trabalhos artísticos por nós realizados nesta pesquisa. 


\subsubsection{Labirintos unicursais}

São aqueles onde não há nenhuma encruzilhada ou bifurcação. Isto significa que eles não oferecem a chance de erro para quem o percorre; para chegar o seu centro, basta seguir em frente.

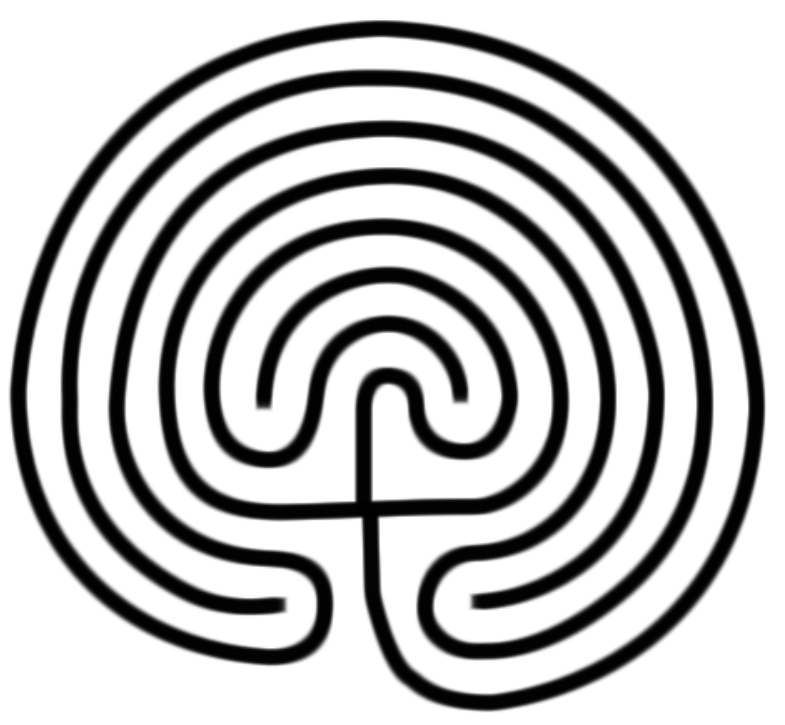

Ilustração 5. Traçado do labirinto unicursal cretense.

A classificação destes traçados unicursais como labirintos é questionada por Rosensthiel (1988b, p. 256), pois eles “negam o fio de Ariadne”, já que não há como perder-se dentro do labirinto. Tal posição é compreensível à medida que Rosensthiel aborda o labirinto a partir de um ponto de vista lógico-matemático, que ressalta o labirinto enquanto desafio. Entretanto, como os labirintos unicursais compartilham outras qualidades com os multicursais (traçado tortuoso, simbolismo do centro, entre outros) e estão fortemente presentes nos estudos sobre o labirinto (como os de Kern e Matthews), nós optamos por seguir a escolha de Leão (2005, p. 93) ao considerá-los como um tipo de labirinto, apesar das ressalvas de Rosensthiel.

Tomando o conjunto de trabalhos por nós realizados ao longo desta pesquisa, encontramos labirintos unicursais em apenas um trabalho, intitulado Para desenhar com os olhos / Para percorrer com os olhos. Ele utiliza o traçado do labirinto de Chartres que, junto com o labirinto cretense, é um dos desenhos mais freqüentes entre as manifestações de labirintos unicursais. Uma descrição mais completa deste trabalho pode ser encontrada na página 41 . 


\title{
1.3.2 Labirintos multicursais
}

O segundo grupo de labirintos é formado pelos traçados multicursais, em que temos bifurcações e encruzilhadas. Quem os percorre pode se deparar com um corredor sem saída (caso em que se é obrigado a voltar atrás) ou, no caso dos labirintos multicursais dotados de $\operatorname{ciclos}^{6}$, retornar a um ponto visitado previamente sem ter, em nenhum momento, dado meia-volta.

\begin{abstract}
Os labirintos multicursais representam a idéia que convencionalmente associamos a labirinto e jogo. Embora mais recentes na história da humanidade, eles acabaram por se tornar o estereótipo que está por trás do sentido de labirinto no senso comum. Os labirintos multicursais nos falam de caminhos que se bifurcam, caminhos que se dividem em acerto e erro, becos sem saída e busca de orientação. Diferente do que ocorre no labirinto unicursal, no qual só é necessário seguir caminhando, pois seus próprio traçado levará ao centro (objetivo), aventurar-se nos labirintos multicursais é desafio. Desafio cognitivo, uma vez que implica várias tentativas e erros e também porque cabe ao viajante propor raciocínios lógicos que o ajudem em sua jornada.
\end{abstract}

(LEÃO, 2002, p. 53. Grifo nosso)

O fato de constituírem um desafio cognitivo, de acordo com a observação de Leão, justifica a sua forte presença nos jogos eletrônicos ("são também temas prediletos dos videogames", conforme a autora). São raras as ocorrências de labirintos unicursais nos jogos que pesquisamos, assim como de configurações espaciais que se aproximem do modelo rizomático, discutido a seguir. Por isso, os labirintos multicursais também são os mais comuns em nossos trabalhos:

- no Estudo \#10, de Prince of Persia: Estudos , podemos ver o traçado dos cenários do jogo, onde cada cenário corresponde a uma fase do jogo. Todos os traçados são multicursais, e a grande maioria possui ciclos;

- os labirintos dos first person shooters, gênero que é tema do trabalho First Person Movements ${ }^{8}$, também são multicursais e dotados de ciclos, em sua grande maioria;

- em O tabuleiros dos jogos que se bifurcam ${ }^{2}$ que faz referência direta ao conto $O$ jardim de veredas que

6 Temos um ciclo quando temos um conjunto de encruzilhadas interconectadas de forma circular. Abaixo, podemos ver um traçado sem ciclos (à esquerda) e um traçado com um ciclo, destacado em vermelho (à esquerda):

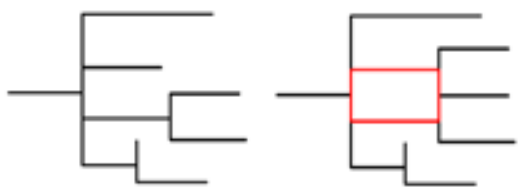

$7 \quad$ Ver texto sobre o trabalho a partir da página página 151

8 Ver texto sobre o trabalho a partir da página página 91.

9 Ver texto sobre o trabalho a partir da página 123. 
se bifurcam, de Borges, temos o jogo que não cessa de se bifurcar, sendo que, em alguns casos, alguns caminhos voltam a se encontrar. Isso ocorre na medida em que, no jogo de xadrez, uma determinada configuração do tabuleiro pode ser alcançada de diferentes maneiras;

- finalmente, temos um algoritmo do tipo profundidade primeiro ${ }^{10}$ gerando labirintos multicursais nos jogos experimentais Labirintos Invisiveis \#1 e \#211 e no trabalho Dédalo e Ariadne, desenvolvido anteriormente à realização desta dissertação.

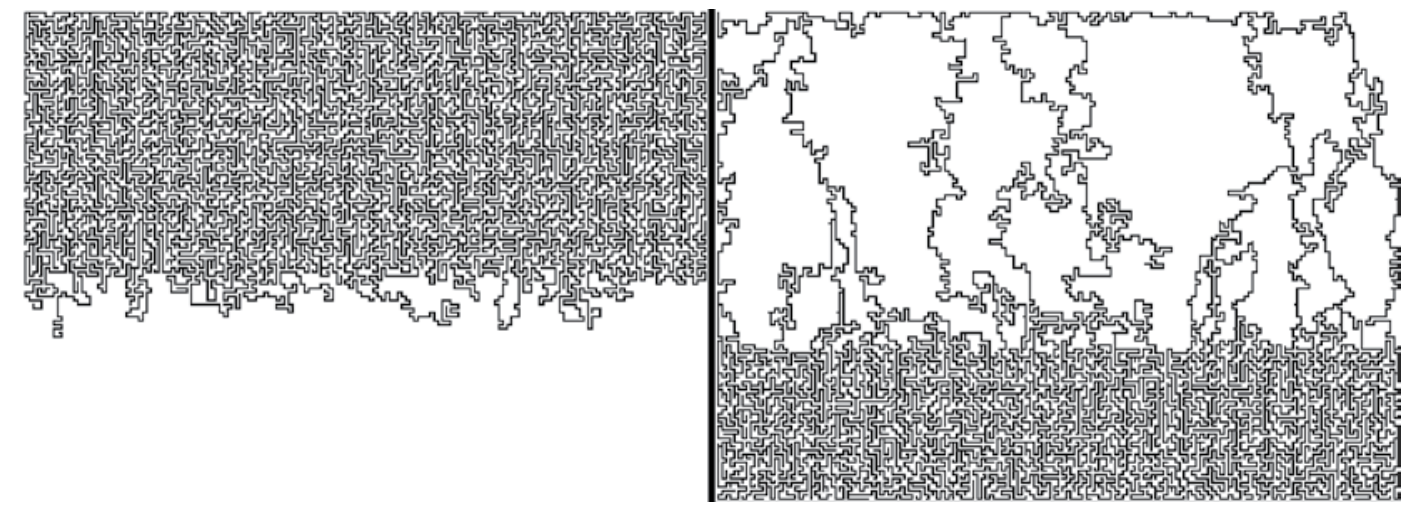

Ilustração 6. Imagem de Dédalo e Ariadne, 2004-2006.

\subsubsection{Rizoma}

Leão propõe o labirinto rizomático como sendo "o labirinto compreendido enquanto rede ou rizoma”, baseando-se nas teorias de Gilles Deleuze e Félix Guattari (LEÃO, 2002, p. 54). Apesar desta abordagem ser desenvolvida, de forma bastante pertinente, em diversas análises sobre as estruturas encontradas na hipermídia e na Internet, o labirinto rizomático não será estudado nesta pesquisa, devido à sua ausência do universo dos jogos eletrônicos. Não queremos, com isso, descartar a hipótese dos princípios do rizoma poderem provocar a criação e proposição de jogos experimentais, mas deixaremos esta possibilidade para futuras pesquisas.

\subsection{Definição de labirinto}

Optamos por revisar as definições de labirinto, em termos formais, após termos recapitulado algumas das tipologias elaboradas pelos autores estudados, por causa da dependência que estas

10 Para maiores informações sobre este algoritmo, consulte http://www.mazeworks.com/mazegen. Visitado em 13/07/2008.

11 Ver texto sobre o trabalho a partir da página página 155. 
definições possuem em relação aos tipos de labirinto sobre os quais seus autores se debruçaram. Esta dependência é particularmente importante no caso de Kern (2000), pois este dedica o seu monumental estudo somente aos labirintos unicursais, conforme assinala no início de seu livro.

Da mesma forma como ocorre em relação aos múltiplos sentidos que o labirinto assume, em suas diversas manifestações, os autores também assinalam a diversidade de formas que são classificadas como labirintos, assumindo posições divergentes em relação a essas classificações. Dentro desta dissertação, assumimos algumas posições que, na nossa compreensão, são mais pertinentes e mais úteis à uma pesquisa dedicada aos labirintos encontrados nos jogos eletrônicos.

A primeira tomada de posição é se formas como a espiral, os nós e emaranhados serão definidos como labirintos ou não. Devido à maneira como o labirinto se manifesta nos jogos eletrônicos (o que será estudado com maior atenção no próximo capítulo), acompanharemos a posição de Santarcangeli e Matthews, que não consideram estas formas - espirais, nós e emaranhados - como sendo labirintos. Se for preciso adiantar as razões que nos levam a ignorar a espiral, os nós e emaranhados, diremos que fazemos isso pela dificuldade de identificar tais formas nos jogos eletrônicos e pelo fato delas não serem percursos, isto é, de não serem espaços pelos quais se pode caminhar.

Entretanto, é preciso observar que ambos reconhecem a proximidade do labirinto com elas - (SANTARCANGELI, 1974, p. 53) e (MATTHEWS, 1970, p. 200) -, e são unânimes em apontar as espirais como antecedentes do labirinto ${ }^{12}$. Também gostaríamos de observar que, se nos afastamos do ponto de vista assumido por Leão em $A$ Estética do Labirinto (2002, p. 31), isto se deve mais por estarmos restringindo o escopo de nossa pesquisa aos jogos eletrônicos. Compreendemos que, dentro do amplo escopo a que ela se dedica neste livro, a consideração destas formas como sendo labirintos mostra-se plenamente justificável.

A segunda tomada de posição é em relação à classificação dos traçados multicursais como sendo labirintos ou não. Dos autores que consultamos, apenas Kern exclui explicitamente os traçados multicursais do conjunto designado pelo termo labirinto. Porém, devemos observar que tanto Matthews quanto Kern podem valer-se de duas palavras diferentes - maze e labyrinth - e usá-las para os labirintos multi e unicursais, respectivamente. Nós não temos esta escolha; em português, há apenas a palavra labirinto. De qualquer modo, entendemos que a exclusão dos labirintos multicursais tornaria esta pesquisa irrelevante, dada a presença, amplamente superior, dos labirintos 12 "A passagem da espiral para um desenho propriamente labiríntico é inegável" (SANTARCANGELI, p. 146). 
multicursais nos jogos eletrônicos. É fácil entender o porquê da grande presença dos labirintos multicursais: um labirinto de caminho único dificilmente chega a se configurar, para o viajante, como um desafio cognitivo.

Após os dois esclarecimentos anteriores, gostaríamos de citar aquela que é, na nossa opinião, a definição mais sucinta do que é um labirinto:

Percurso tortuoso, onde talvez pode-se, sem guia, perder-se facilmente.

(SANTARCANGELI, 1974, p. 47. Tradução nossa, grifo do autor. ${ }^{13}$ )

O uso do advérbio talvez é essencial para que não sejam excluídos os labirintos unicursais. Já o adjetivo tortuoso exclui percursos simples, como uma linha reta. Finalmente, o substantivo percurso obriga o nosso objeto a ter, pelo menos, uma entrada. De acordo com esta definição, ele poderá ter um centro ou não (ponto de divergência entre os autores que estudamos; alguns consideram a presença de um centro, claramente definido, como sendo obrigatória para que um traçado seja considerado um labirinto [SANTARCANGELI, 1974, p. 213] ), e a saída poderá ou não coincidir com a entrada. De qualquer modo, o labirinto deverá configurar-se como um espaço passível de ser percorrido. E é assim que o labirinto se manifesta nos jogos eletrônicos, como veremos no segundo capítulo deste trabalho. Nos labirintos temporais, não é diferente; basta observar que ao escrever o conto que é a nossa principal referência de labirinto temporal, O jardim de veredas que se bifurcam, Borges (2008a) utilizou a imagem de veredas (caminhos a serem percorridos) para definir a estrutura do livro-labirinto escrito pelo personagem Tsui Pên. Este conto será retomado do terceiro capítulo desta dissertação, assim como no texto sobre o trabalho O tabuleiro dos jogos que se bifurcam, página 123 .

\subsection{A experiência de percorrer o labirinto}

Em seu texto sobre o labirinto, citado tanto por Machado (1997b), quanto por Leão (2005) e Calabrese (1987), Rosensthiel (1988b) opõe a experiência do criador do labirinto àquela vivenciada por quem explora o labirinto sem conhecer o seu percurso ("sem mapa").

(O viajante) pode entrar em encruzilhadas já vistas, ou noutras que são reprodução de encruzilhadas já visitadas. Tudo isso lhe provoca surpresa, confusão, espanto (em inglês labyrinth tem como sinônimo maze, objeto de estupefação). Corredores e encruzilhadas alternados são, para o viajante a única certeza que se repete, de vez em quando. Tudo lhe

13 Texto da tradução francesa: Parcours tortueux, où parfois il est facile, sans guide, de perdre son chemin. 
parece infinito, tão desconcertante é a ilusão das similitudes (o viajante tem, de fato, a intuição do poder ilimitado da uniformidade). (...)

Mas, se o viajante errante experimenta uma sensação de infinito no labirinto, o arquiteto conhece-o como finito. A sua engenhosidade doseou o efeito de engano e o efeito de sedução nos emaranhados, ramificações, desvios e regressos. O viajante é absorvido pela procura; e a vertigem que lhe invadiu o espírito irá dissipar-se graças a uma exploração mais profunda. O labirinto é humano.

(ROSENSTHIEL, 1988b, p. 251)

A análise que Rosensthiel faz das duas experiências é bastante pertinente a este estudo, pois criamos trabalhos que, se obtiverem êxito, proporcionarão uma experiência labiríntica ao interator ou, então, lhe farão perceber a presença do labirinto nos jogos eletrônicos. Assim, assumimos tanto a posição de criador de labirintos quanto a de quem estuda as criações de Dédalo, encontradas nos jogos eletrônicos que analisamos.

Entretanto, Rosensthiel conclui a análise afirmando que quem faz o labirinto é o viajante e não o arquiteto. "O labirinto não é uma arquitetura, uma rede no sentido de quem o projeta e concebe, mas o espaço que se desdobra diante do viajante que progride, sem mapa, na própria rede" (ROSENSTHIEL, 1998b, p. 251). Apesar de, na nossa prática artística, termos nos debruçado, incontáveis vezes, sobre o problema da construção de labirintos, e de termos estudado o assunto, nesta pesquisa nos guiaremos pelo ponto de vista de Rosensthiel. Nos concentraremos na experiência do viajante, deixando para futuras ocasiões uma descrição dos métodos de construção de labirintos, bem como um possível estudo sobre a prática de criar trabalhos e ambientes cujo objetivo é serem percebidos como labirínticos ${ }^{14}$.

Ao falarmos sobre aquele que percorre um labirinto, é preciso observar que nem sempre seu objeto é encontrar a saída. Muitas vezes também é, mas só após ter realizado alguma tarefa. Estes são os casos de Teseu e das situações em que o labirinto é associado a rituais de iniciação, onde deve-se alcançar o centro do labirinto (CHEVALIER, 2003, p. 531). Também é, de acordo com Leão, o caso do internauta que realiza uma busca na rede:

O símbolo do centro, conforme nos relata Eliade, está presente em várias culturas e relaciona-se à zona do sagrado, à realidade absoluta, Muitas vezes associa-se à idéia de montanha sagrada, território em que se encontram o céu e a terra. Em quase todas as mitologias primitivas, o centro é um local de difícil acesso e exige do fiel uma peregrinação árdua, cheia de perigos. Assim, o centro, como imagem mítica, pode ser resgatado para um contraponto com as atividades de navegação do internauta. Nesse sentido, não estou me referindo a um centro de poder ou a uma visão hierarquizante, mas sim a um objetivo que o pesquisador lutou para alcançar. A partir de uma metodologia simultaneamente

14 Sobre os aspectos labirínticos da criação em hipermídia, consultar (LEÃO, 2006), com especial atenção para o quinto capítulo, Os três labirintos. 
acentrada e policêntrica, o viajante do ciberespaço traça seu mapa de domínio de uma forma mais fluida e dinâmica sem se fixar em um centro único, como faria um pesquisador de postura centrada. Mesmo assim, o nosso herói precisa passar por vários ritos de passagem. Após cada conquista, diversos centros simbólicos, pontos de consagração resultantes de um longo trabalho, cintilam na constelação. Vemos então que, para o pesquisador da era nômade digital, não basta uma única expedição do Velocino de Ouro. Para o nômade, são necessárias diversas jornadas.

(LEÃO, 2005, p. 70)

Outros casos envolverão situações em que o viajante deve explorar o labirinto ao máximo, percorrendo todos os seus caminhos. Tal idéia é encontrada em Machado (1997b) e será analisada, com maiores detalhes, a seguir.

\subsection{A associação entre labirintos e novas mídias}

Abordaremos a associação entre o labirinto e as novas mídias a partir das pesquisas de Arlindo Machado e Lucia Leão sobre este tópico. Machado publicou os primeiros textos sobre o assunto nos anos 90, enquanto que Leão se dedicou ao tema a partir de suas pesquisas de mestrado (defendida em 1997) e doutorado (2001), ambas desenvolvidas com a orientação de Machado.

No artigo Hipermídia: o labirinto como metáfora, publicado em 1997, Machado aponta a complexidade presente na hipermídia - "(ela) permite justamente exprimir tais situações complexas, polissêmicas e paradoxais que uma escritura seqüencial e linear, plena de módulos de ordem, jamais poderia representar" (MACHADO, 1997b, p. 148) - e elege o labirinto como "a melhor metáfora para a hipemídia", "pois a hipermídia reproduz com perfeição a estrutura intricada e descentrada deste último” (idem, p. 149).

O desenvolvimento deste raciocínio, tal como feito por Machado, apresenta diversos pontos pertinentes à nossa pesquisa. O primeiro é a observação de que

\footnotetext{
o labirinto cretense não era uma prisão ou uma máquina de guerra, mas exatamente uma arquitetura representativa da complexidade máxima que a imaginação do homem da Antigüidade podia conceber e servia também de espaço para festas e jogos. A saída não era propriamente um problema para o visitante. Na mitologia grega, Dédalo escapa de seu próprio labirinto voando por cima dele com suas asas de cera, mas os cretenses podiam simplesmente pular os muros, como o moderno navegante da hipermídia pode "clicar" o botão Quit e desistir do percurso. O problema, na verdade, era como avançar sem perder-se: o labirinto funcionava, portanto, como um desafio para medir a astúcia do visitante.

(MACHADO, 1997b, p. 149. Grifos nossos)
}

A seguir, encontramos o segundo ponto de grande importância para o nosso trabalho. Ci- 
tando Rosensthiel (1988b), Machado lembra que "o labirinto convida à exploração" e nos mostra que o objetivo daquele que está dentro de um labirinto não é, necessariamente, encontrar a saída. "O melhor percurso não era aquele que permitia chegar mais depressa ao fim, mas o que possibilitava visitar o maior número possível de lugares, sem ficar repetindo infinitamente o mesmo caminho". A tarefa de encontrar tal percurso "funcionava, portanto, como um desafio para medir a astúcia do visitante" (Machadob, 1997, p. 149, grifo do autor). Esta observação é essencial para a análise dos jogos eletrônicos que realizamos, pois eles muitas vezes apresentam labirintos que precisam ser percorridos em sua totalidade. Um dos casos mais evidentes é o jogo de PacMan, analisado com maiores detalhes na página 53, onde o jogador precisa percorrer todos os caminhos de um labirinto para passar de fase. Neste jogo, passar novamente por um caminho constitui mera perda de tempo para o jogador.

A seguir, o autor se refere ao conto O jardim de veredas que se bifurcam, de Borges, e faz diversas relações entre a "escritura paradoxal" imaginada por Borges e a hipermídia, finalizando o texto abordando o filme Smoking / No Smoking, de Alain Resnais. Retomaremos estas últimas referências no capítulo dedicado aos labirintos temporais e ao comentar o trabalho O tabuleiro dos jogos que se bifurcam, a partir da página 123 .

Finalizando os comentários sobre este artigo, é importante observar que Machado aponta, também, para os aspectos labirínticos do jogo Myst, onde "é difícil resistir à tentação de explorar todas as suas veredas, na tentativa de descobrir os mistérios que se escondem nos seus detalhes mais discretos”. Este jogo será retomado no próximo capítulo desta dissertação, a partir da página página 71 .

Por sua vez, Leão, em O Labirinto da Hipermídia, utiliza o labirinto como uma chave para abordar a hipermídia e mapear as suas características, utilizando como referência estudos sobre o hipertexto e mitos envolvendo o labirinto, não se restringindo ao caso cretense. Como objetos hipermidiáticos, a autora aborda desde experiências pioneiras, como o projeto Memex, de Vannevar Bush, e Xanadu, de Ted Nelson, até sites e CD-ROMs produzidos na época de realização da pesquisa. Ela também olha para a própria Internet como sendo uma manifestação do labirinto na hipermídia (LEÃO, 2005, pp. 22-26). Outros tópicos abordados por Leão no desenvolvimento do livro são a interatividade, o leitor-ativo e novas relações de autoria, teorias da complexidade, a 
não linearidade, a autoria em hipermídia e a metáfora da navegação, sempre tendo o labirinto e a manifestação de características labirínticas na hipermídia como fio condutor de seu texto.

Já em Estética do Labirinto, livro resultante de sua pesquisa de doutorado, Leão inicia elaborando um mapeamento dos sentidos que o labirinto adquire, nas mais diversas manifestações, abarcando desde os mitos da Antigüidade até a presença do labirinto nas novas mídias (baseando-se em seu trabalho anterior). Este mapeamento será utilizado como base para a leitura de inúmeras obras de arte, onde a autora identifica uma "estética do labirinto", sendo que as leituras são realizadas ao longo de todo o livro. O mapeamento de sentidos do labirinto é seguido por duas etapas. Primeiro, Leão aponta os mapas do ciberespaço (mapeamentos diversos, utilizados por profissionais ligados à Internet, como os gráficos que apresentam o tráfego de dados para administradores de redes) como uma manifestação do labirinto, e, em seguida, estuda a multiplicidade de sentidos do espelho. Espelho e labirinto são, por fim, articulados numa instalação multimídia, intitulada Labirinto, apresentada em 2001 e descrita no último capítulo do livro.

Finalmente, devemos observar que a autora organizou diversas coletâneas de textos sobre novas mídias, além de se voltar para o que ela chamou de "mapas do ciberespaço" - gráficos de visualização de dados sobre a Internet que, de certa forma, efetuam um mapeamento da rede ${ }^{15}$. Nestes mapas, Leão identifica traços labirínticos que ela analisa, dando continuidade à pesquisa sobre o labirinto nas novas mídias. 

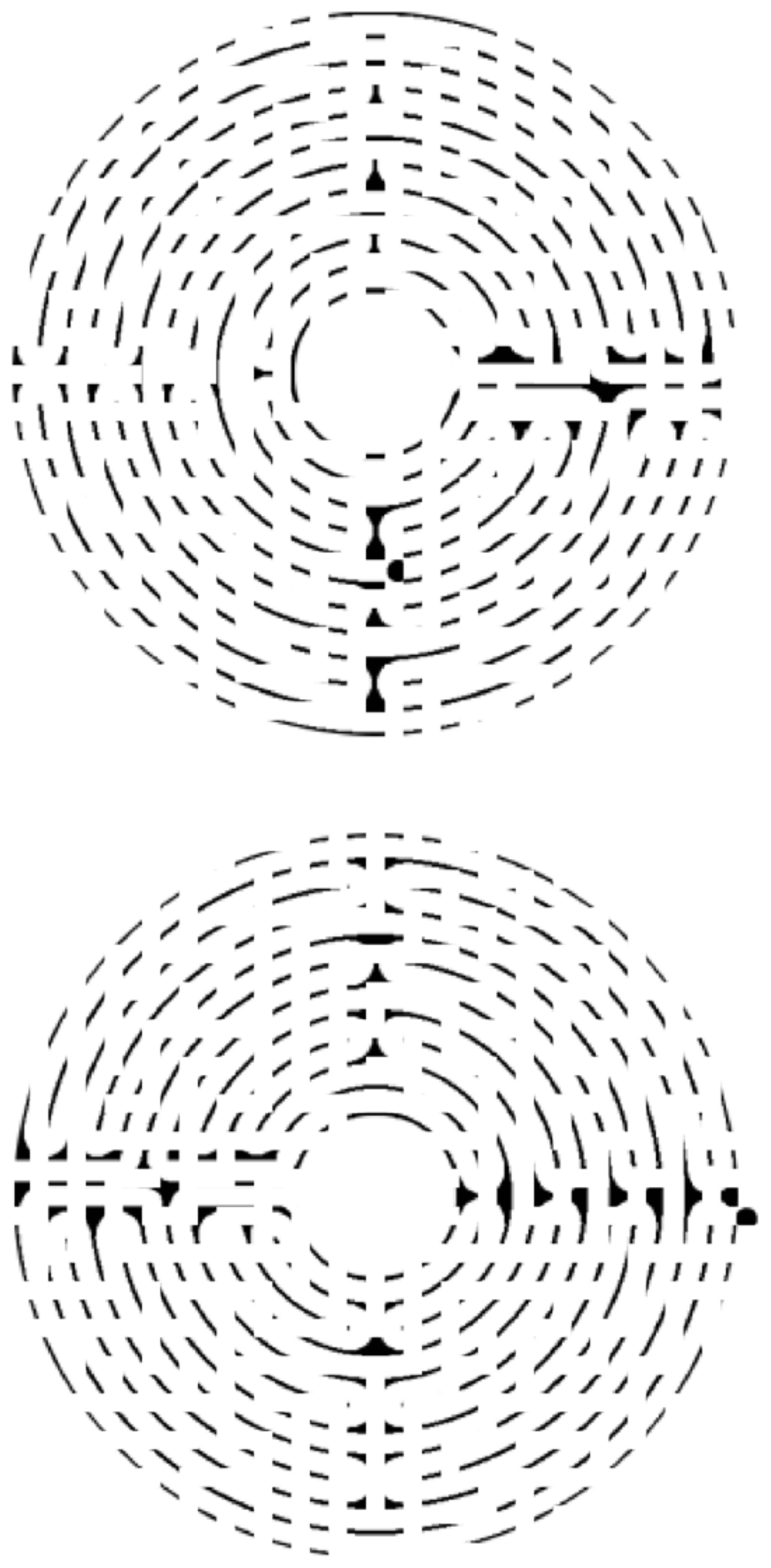



\section{A Para desenhar com os olhos / Para percorrer com os olhos}

No primeiro capítulo desta dissertação, fizemos menção aos labirintos encontrados em igrejas cristãs, principalmente em igrejas medievais, e às diversas hipóteses apresentadas pelos estudiosos de labirintos para a sua realização página 26. Entre elas, estava a possibilidade do labirinto representar a peregrinação até a cidade de Jerusalém; percorrer os labirintos construídos em igrejas seria uma forma daqueles que não tinham como visitar a Cidade Sagrada fazê-lo ${ }^{16}$. Também é citada a hipótese de que o deslocamento pelo labirinto fosse uma forma de penitência (MATTHEWS, 1970, p. 67).

Os labirintos das igrejas medievais, tais como o da Catedral de Chartres, seriam percorridos a pé ou de joelhos pelos fiéis, mas Matthews também se refere aos labirintos desenhados em paredes, comentando que o percurso "seria efetuado pelo dedo indicador" (idem). Tal colocação nos levou ao desafio de percorrer o desenho de um labirinto apenas com o olhar, sem fazer uso de qualquer forma de apoio (como o dedo indicador ou um lápis). E é este desafio a origem de nosso trabalho Para desenhar com os olhos / Para percorrer com os olhos.

O trabalho consiste numa animação, disponível para visualização em http://www.andreithomaz.com/arte/chartres . A animação apresenta, na metade direita, o desenho do labirinto existente na Catedral de Chartres. $\mathrm{Na}$ metade esquerda, temos um pequeno círculo preto, que percorre um caminho semelhante ao do labirinto, mas sobre um fundo branco.
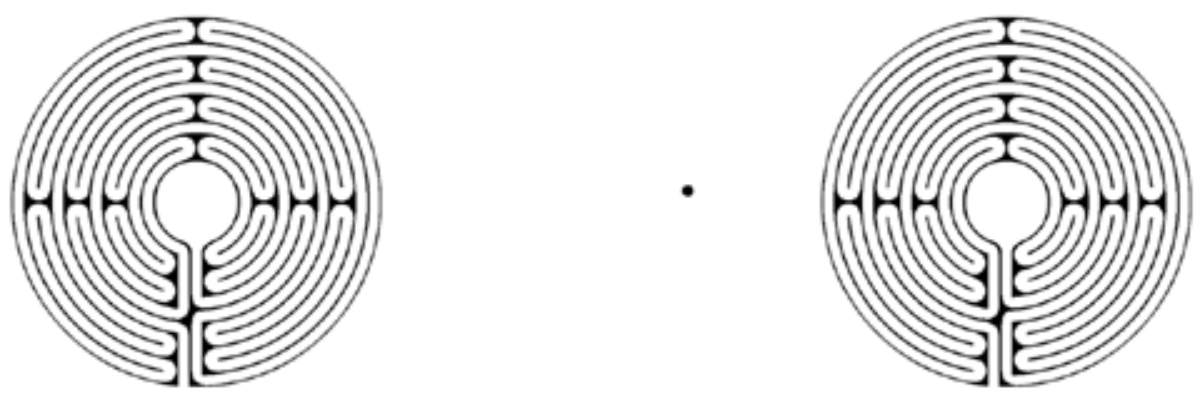

Ilustração 7. Imagens de Para desenhar com os olhos / Para percorrer com os olhos.

16 Tais hipóteses são citadas por Matthews (1970, pp. 54-70), Kern (2000, pp. 143-165) e Santarcangeli (1974, pp. 282-3). 
Percebemos três desafios diferentes sendo apresentados ao espectador em Para desenhar com os olhos / Para percorrer com os olhos. O primeiro é, evidentemente, conseguir percorrer o labirinto com os olhos, sem o uso de nenhum recurso auxiliar. O segundo é detectar a semelhança entre o percurso do círculo preto com o desenho do labirinto. Finalmente, o terceiro desafio é projetar o labirinto sobre o círculo, fazendo uso do fenômeno da pós-imagem. Isto porque, se olharmos para o labirinto por um determinado período de tempo e deslocarmos o nosso olhar para o ponto preto, o desenho do labirinto ficará "gravado" em nossa visão por alguns segundos, nos permitindo ver o pequeno círculo deslocando-se dentro do labirinto. 

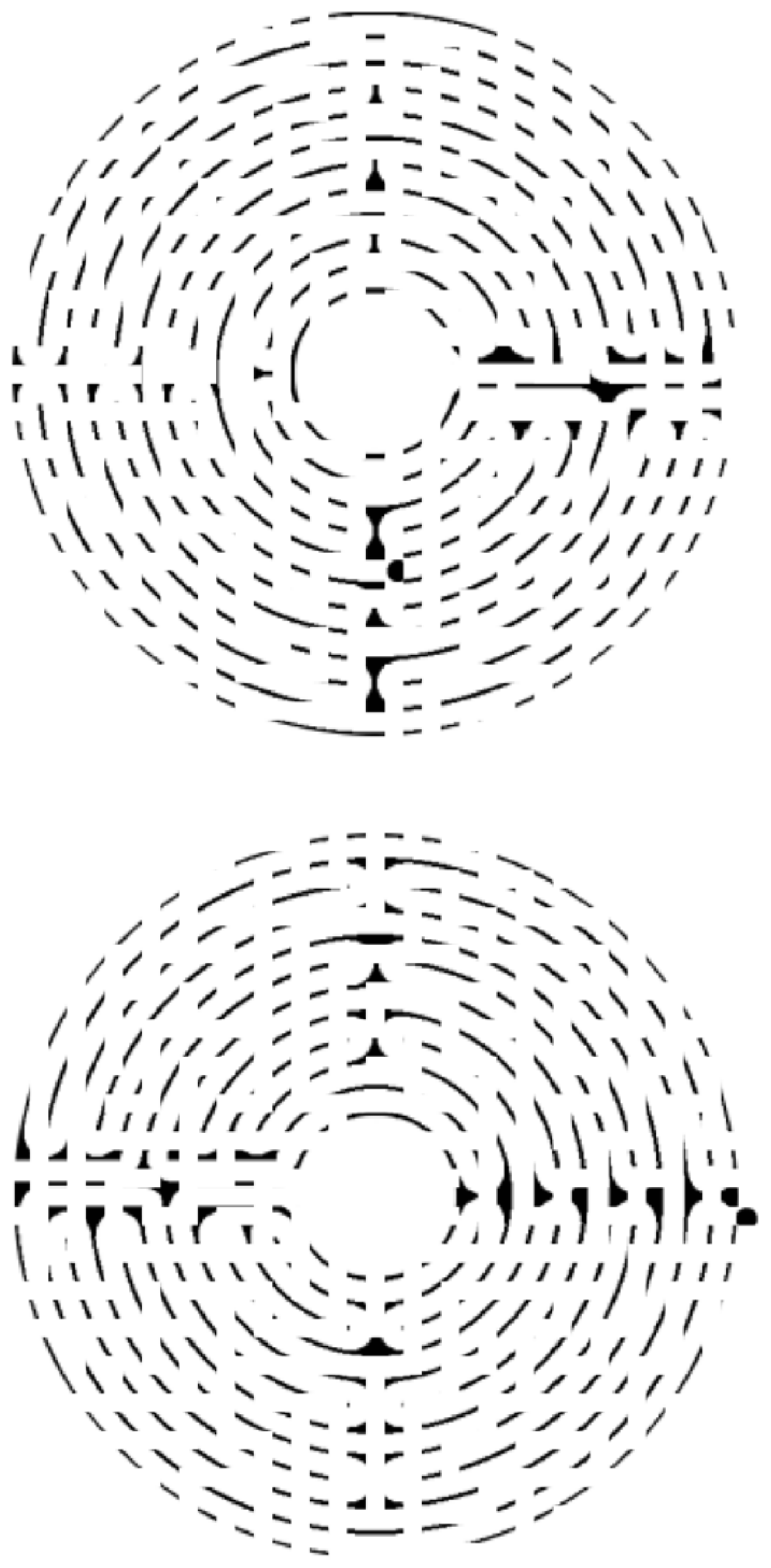



\section{Manifestações espaciais do labirinto nos jogos eletrônicos}

Entre os diversos caminhos possíveis para o mapeamento das manifestações espaciais do labirinto nos jogos eletrônicos, optamos por seguir a categorização dos tipos de espaço empregados nos jogos, tal como elaborada por Mark J. P. Wolf em The Medium of the Videogame ${ }^{17}$, com o acréscimo de duas categorias ${ }^{18}$ para contemplar alguns jogos e projetos de pesquisa desenvolvidos recentemente. Optamos por não utilizar outras categorizações, como a classificação em gêneros, que é bem mais presente nos estudos sobre os jogos eletrônicos, pois o nosso objetivo neste capítulo consiste em nos concentrarmos na maneira como os jogos estruturam o espaço lúdico, e em como este espaço pode ter características labirínticas.

Com base na taxonomia elaborada por Wolf, buscamos, para cada tipo de espaço, jogos onde o labirinto estivesse presente de alguma forma, não definida previamente. Isto é, não buscamos por um tipo de manifestação específica do labirinto, mas sim procuramos estabelecer relações entre os jogos analisados e a bibliografia sobre o labirinto que nós utilizamos como parte de nosso referencial teórico, apresentada no capítulo anterior.

É preciso observar que, neste momento, vamos analisar a presença do labirinto em termos espaciais. Em relação à experiência do tempo nos jogos eletrônicos, são poucos os casos em que não temos uma experiência linear. Por isso, esses casos excepcionais serão analisados no capítulo seguinte, junto com referências da literatura e do cinema ${ }^{19}$.

\subsection{Os tipos de espaço}

Wolf define onze tipos de espaço principais, também indicando diversas formas adicionais de representação espacial. É importante observar que esta taxonomia se relaciona com o desenvolvimento dos jogos e da tecnologia que lhe dá suporte, assim como com a busca do realismo por parte da indústria dos jogos, que privilegia, nos dias de hoje, a representação do espaço de acordo

17 WOLF, Mark J. P. Space in the Video Game. In: University of Texas Press, 2002. pp. 51-75.

18 Jogos que utilizam Internet de outra forma que não para tornar os jogos multiusuários e jogos que utilizam o espaço urbano.

19 Recorremos à literatura e ao cinema para termos um repertório mais amplo de possibilidades de trabalho com a percepção e experiência do tempo nos jogos eletrônicos. 
com as regras da perspectiva renascentista. ${ }^{20}$

2.1.1 Jogos baseados em texto, sem gráficos

São jogos de computador que

são completamente baseados em texto ${ }^{21}$; o cenário, personagens e objetos ao redor do jogador são apresentados na forma de descrições verbais apresentadas como texto na tela do computador, e as respostas e ações do jogador são comandos digitados, tais como 'norte' ou 'abrir porta'. Neste sentido, não há nenhum espaço na tela sobre o qual falar; tudo deve ser imaginado a partir das descrições.

(WOLF, 2002, p. 54. Tradução nossa) ${ }^{22}$

Estes jogos só existiram enquanto jogos de computador, e não como jogos para consoles $^{23}$, pois eles exigem o uso do teclado e de uma forma de interação (uso de comandos textuais, digitados) que é familiar aos usuários de computadores (estamos falando dos computadores pré-interfaces gráficas), mas não aos usuários dos consoles domésticos.

Para refletir sobre a presença do labirinto neste tipo de jogo, recorremos ao estudo de Nick Monfort sobre ficção interativa ${ }^{24}$, intitulado Twisty Little Passages (MONTFORT, 2004), em que o autor aborda diversos jogos baseados em texto e peças de ficção interativas ${ }^{25}$. Apesar dele não abordar todos os tipos de jogos baseados em texto (estão fora de seu estudo os mundos virtuais multiusuários baseados em texto - MUDs, nos quais a interação entre os usuários se mistura à construção/leitura de uma narrativa), ele nos oferece os elementos necessários para identificar como o

20 No artigo Abstraction in the Video Game, Wolf analisa o uso da abstração nos primeiros jogos eletrônicos em função do baixo poder de processamento da tecnologia da época, e aponta o seu declínio em prol do realismo, acompanhando o desenvolvimento tecnológico. (WOLF, Mark J. P. Abstraction in the Video Game. In: ; PERRON, Bernard (ed.). The Video Game Theory Reader. New York : Routledge, 2003. pp. 47-65.

21 Wolf não menciona, mas, a partir do lançamento de Mystery House por Ken e Roberta Williams em 1980, este gênero de jogo passou a utilizar cada vez mais imagens e desenhos, que atuavam como mapas ou ilustrações do que estava sendo descrito verbalmente. Mystery House era um jogo baseado em texto, mas que também exibia desenhos construídos apenas com caracteres de texto. (MONTFORT, 2004, p. 149)

22 Texto original em inglês: are completely text based; the scenery, other characters, and the player's surroundings are presented as verbal descriptions delivered as text on-screen, and the player's replies and requests are typed commands, such as "north" or "open door". In this sense, there is no on-screen space to speak of; everything has to be imagined on the basis of the descriptions.

23 Aparelhos de videogame, para uso doméstico. Não possuíam uma tela própria, de modo que precisavam ser acoplados à televisão, para que esta fosse utilizada como a tela do jogo.

24 Termo utilizado por Montfort.

25 Apesar dos dois gêneros utilizarem os mesmos recursos técnicos, é importante citar ambos para ressaltar que, além dos jogos que eram comercializados e distribuídos como entretenimento, sem apresentar maiores pretensões artísticas, há uma produção de trabalhos que possui um cunho mais experimental e artístico, e que é analisada por Montfort neste livro, sob o rótulo de fição interativa. 
labirinto se manifesta neste formato de jogo.

A partir do estudo de Montfort e de nossa interação com os jogos baseados em texto $A d$ venture (Crowther \& Woods, 1976) e Zork (Anderson, Blank, Daniels e Lebring, 1977), percebemos que o que aproxima a experiência de jogar tais jogos do labirinto é o modo como se dá a nossa percepção e a construção do espaço do jogo, na medida em que esta construção ocorre a partir de informações locais ${ }^{26}$, apresentadas de forma fragmentada, de modo semelhante à análise mediante fragmentos, descrita por Calabrese no texto Pormenor e Fragmento ${ }^{27}$. Neste texto, uma das diferenciações entre detalhe ${ }^{28}$ e fragmento estabelecidas por Calabrese é a de que, quando temos um detalhe, nós temos, de antemão, a visão do todo a partir do qual o detalhe será examinado; já o fragmento implica uma situação em que a parte remete para um todo "suposto como ausente", que precisa ser reconstituído. No caso dos jogos baseados em texto, nós, enquanto jogadores, temos que reunir as informações locais (descrições de cenários e das possibilidades de movimentação) para esboçar uma visão global do espaço, tentando mapeá-lo, já que ele não nos é dado previamente. É o que ocorre no labirinto, onde podemos ver apenas as opções imediatas de deslocamento, sem ter clareza sobre onde podemos chegar se seguirmos cada uma delas ${ }^{29}$. O espaço do jogo não inclui apenas os caminhos possíveis, mas também os elementos presentes nos diversos pontos (nós) do jogo; mais do que "espaço do jogo", devemos falar em percepção do "modelo de mundo" empregado em cada um dos jogos baseados em texto, tal como é definido por Monfort:

O modelo de mundo normalmente é implementado num programa de ficção interativa na forma de um grafo ou árvore de estruturas de algum tipo (por exemplo, registros, objetos, lista) com procedimentos, métodos ou funções associados (Graves, 1987) ${ }^{30}$. Ele representa o ambiente físico da ficção interativa e as coisas neste ambiente, incluindo personagens, quaisquer objetos físicos no cenário que possam ser manipulados ou examinados de diversas maneiras, e o personagem do jogador. Ele também representa e simula as leis físicas daquele "cenário" - razão por que o modelo do mundo é mais apropriadamente chamado de mundo ficcional interativo. A passagem do tempo, as formas possíveis com que o jogador pode avançar através das tarefas e objetivos que lhe são colocados, o nível de consciência dos diversos personagens e fatores como a presença ou

26 Para uma discussão dos termos local/global, ver Petitot (1988).

27 CALABRESE, Omar. Pormenor e Fragmento. In: —, A Idade Neobarroca. Lisboa: Edições 70, 1987. p. 83105.

28 Utilizamos detalhe ao invés de pormenor por este termo ser mais usual no português brasileiro, tendo em vista que a tradução lida por nós do texto de Calabrese foi editada em Portugal.

29 Nas palavras de Calabrese, “a reconstrução procede de resto por inferências locais". CALABRESE, Omar. Nó e Labirinto. In: A Idade Neobarroca. Lisboa : Edições 70, 1987. p. 145-158.

30 A referência do texto citado por Montfort é

GRAVES, David. "Second Generation Adventure Games." The Journal of Computer Game Design. 1(2) (August 1987): 4-7. Disponível via WWW url http://www.tela.bc.ca/tads/authoring/articles/graves1.htm/endereco válido quando Montfort o consultou; atualmente, o texto está disponível em http://teladesign.com/tads/authoring/ articles/graves1.htm. Consultado em 26/11/2006). 
ausência de luz em diferentes áreas são, todas elas, controladas pelo modelo de mundo. (MONTFORT, 2004, p. ix. Tradução nossa) ${ }^{31}$

Para ilustrar a forma como o jogador de um destes jogos baseados em texto conhece o cenário do jogo, transcrevemos parte de uma sessão de jogo de Zork I $^{32}$ :

\begin{tabular}{|c|c|}
\hline Transcrição & Tradução ${ }^{33}$ \\
\hline West of House & Lado oeste da casa \\
\hline $\begin{array}{l}\text { You are standing in an open field west } \\
\text { of a white house, with a boarded front door. } \\
\text { There is a small mailbox here. }\end{array}$ & $\begin{array}{l}\text { Você está no lado oeste de uma casa branca, } \\
\text { sem muros, com uma porta emoldurada. Há uma } \\
\text { pequena caixa de correio aqui. }\end{array}$ \\
\hline$>$ look at mailbox $x^{34}$ & > olhe na caixa de correio \\
\hline The small mailbox is closed. & A caixa de correio está fechada. \\
\hline > open mailbox & > abra a caixa de correio \\
\hline Opening the small mailbox reveals a leaflet. & $\begin{array}{l}\text { Ao abrir a pequena caixa de correio, } \\
\text { você encontra um folheto. }\end{array}$ \\
\hline$>$ read leaflet & > leia o folheto \\
\hline (Taken) & (Pegando o folheto) \\
\hline "WELCOME TO ZORK! & "BEM-VINDO A ZORK! \\
\hline $\begin{array}{l}\text { ZORK is a game of adventure, danger, and low } \\
\text { cunning. In it you will explore some of the most } \\
\text { amazing territory ever seen by mortals. No computer } \\
\text { should be without one!" }\end{array}$ & $\begin{array}{l}\text { ZORK é um jogo de aventura, perigo e com um pouco } \\
\text { de estratégia. Nele você explorará alguns dos terrenos } \\
\text { mais fantásticos já vistos pelos mortais. } \\
\text { Todo computador deveria possuir Zork instalado!" }\end{array}$ \\
\hline$>$ open door & $>$ abra a porta \\
\hline The door cannot be opened. & A porta não pode ser aberta \\
\hline$>w^{35}$ & $>0$ \\
\hline Forest & Floresta \\
\hline There is a forest, with trees in all directions. & Há uma floresta, com árvores em todas as direções. \\
\hline To the east, there appears to be sunlight. & Parece haver luz do sol seguindo em direção oeste. \\
\hline$>w$ & $>0$ \\
\hline You would need a machete to go further west. & Você precisaria de um facão para seguir a oeste. \\
\hline
\end{tabular}

Podemos perceber que, apenas após algum tempo de jogo, o jogador consegue criar uma imagem mental, um mapa, do cenário em que se encontra, e das suas possibilidades de movimento

31 Texto orignal em inglês: The world model is typically implemented in the interactive fiction program as some type of graph of three of structures of some sort (e.g., record, object, list) with associated procedures, methods, or functions (GRAVES, 1987). It represents the physical environment of the interactive fiction and the things in that environment, including characters, any physical object in the setting that can be manipulated or further examined in any way, and the player character. It also represents, and stimulates, the physical laws of that "setting" - one reason this elements is more appropriately called the interactive fiction world. The passage of time, the player character's possible ways of progressing through the required tasks, the levels of awareness of different characters, and such things as the presence or absence of light in different areas are all modeled by this component.

32 Utilizamos a versão de Zork I disponível para download em http://www.infocom-if.org/downloads/downloads. htm Esta versão permite que Zork I seja jogado em um PC atual.

33 A tradução é de nossa autoria.

34 O texto após o sinal de maior que, > , é o comando digitado pelo jogador.

35 Forma abreviada do comando west. 
e de ação. Serão necessárias diversas voltas ao ponto de partida e até mesmo anotações e desenhos em papel, até que se atinja um grau razoável de orientação espacial dentro do jogo.

2.1.2 Jogos com espaço restrito às dimensões da tela

São aqueles em que todo o espaço do jogo pode ser visualizado na tela, de uma vez só, sem o uso de qualquer tipo de rolagem ${ }^{36}$ ou deslocamento da tela. Os primeiros jogos eletrônicos, sejam de computador, para consoles ou do tipo arcade $^{37}$, eram deste tipo.

Se os jogos baseados em texto privilegiam as informações locais, em detrimento da visão geral do espaço do jogo, estes jogos oferecem, de imediato, a visão global do espaço lúdico, de forma que o jogador percebe, rapidamente, quais as suas possibilidades de ação e deslocamento, afastando a possibilidade de desorientação ou de perda de referências espaciais.

Wolf faz uma diferenciação entre os jogos em que os limites da tela são limites também do espaço do jogo e aqueles em que, ao se deslocar além do limite da tela, o jogador (ou outro elemento do jogo) reaparece do lado inverso.

Tanto nos tipos de espaço 2 (uma tela, espaço totalmente visível) e 3 (uma tela, espaço totalmente visível, com "espaço contínuo/emendado" 38 ), o jogador pode ver tudo o que há para ser visto no jogo na tela e provavelmente se concentrará mais no personagem controlado por ele. Entretanto, as reações aos dois tipos de espaço apresentam algumas diferenças: no tipo 2 os cantos da tela são paredes, e assim é possível virar as costas para elas, de forma segura, com o foco de atenção sendo o centro da tela, de onde os inimigos e outros elementos do jogo costumam vir. No tipo 3, alvos ou perseguidores podem desaparecer num lado da tela e reaparecer no lado oposto, de forma que deve-se prestar mais atenção aos cantos, uma vez que é mais difícil acompanhar estes movimentos de desaparecimento e aparição repentina. Apesar de que, em ambos os casos a ação fica totalmente contida na tela, partes diferentes da tela ganham importância e requerem atenção dependendo da forma como o espaço é configurado.

(WOLF, 2002, pp. 56-57. Tradução nossa) $)^{39}$

36 Ver próximo tipo de espaço.

37 Jogados em cabines, conhecidos no Brasil como fliperamas. Ao contrário dos consoles, destinados a uso doméstico, os arcades exigiam que os jogadores fossem até os locais onde as cabines estivessem instaladas.

38 Traduzimos "wraparound" para "espaço contínuo/emendado" por falta de termo mais adequado.

39 Texto original em inglês: In both type 2 and type 3 (one screen, contained, with wraparound) spaces, the player can see everything there is to see on-screen and will probably concentrate most on the character represented there which will he or she is controlling. However, the reactions to the two spaces differ somewhat; in type 2 the edges of the screen are walls, and thus it is safe to turn one's back to them; the focus then, becomes mainly the center of the screen, where threats are more likely to come from. In type 3, targets or attackers can disappear off one side of the screen and reappear on the far side, and so edges must be paid more attention, since it is often harder to keep track of these off-and-on movements. Although in both cases the action is wholly contained on-screen, different parts of the screen become important and require attention depending on how the space is configured. 
Apesar da influência que isto tem sobre o comportamento do jogador, optamos por agrupar os jogos nas duas categorias de Wolf dentro desta pesquisa, por entendermos que, para os nossos objetivos, a sua característica principal é o fato deles oferecerem uma visão global do jogo. Assim, dentro dessa categoria, encontramos alguns jogos que utilizam labirintos ou espaços que guardam certas características próximas ao mesmo. O mais conhecido é, sem dúvida, o jogo PacMan, que é, até hoje, um dos jogos mais fortemente associados ao labirinto, como será visto na página 53. Também devemos mencionar os jogos: Tank (Kee Games, 1974), Gotcha (Atari, 1973), Dig Dug (Namco, 1982), Amažing Maze (Midway, 1976) e Maze Craze (Atari, 1978).

\subsubsection{Gotcha}

Gotcha foi o quarto jogo desenvolvido pela Atari, após Pong, Space Race e Pong Doubles (DE MARIA e WILSON, 2003, p. 24), e consiste num jogo para duas pessoas em que o objetivo de uma delas (representada por um quadrado) é perseguir a outra (representada por um sinal de menos) pelos corredores de um labirinto (GOTCHA, 2006).

Não conseguimos obter imagens do jogo (apenas de anúncios publicitários do mesmo) mas a importância de Gotcha está no fato de ser considerado o jogo que inaugura o gênero dos jogos de labirinto (DE MARIA e WILSON, 2003, p. 24 e BURNHAM, 2001, p. 93). Por exemplo, Russel DeMaria e Johnny L. Wilson o definem como o "primeiro jogo de perseguição em labirintos" e "um precursor para jogos como Pac-Man”.

\subsubsection{Maze Craze e Amazing Maze}

Amazing Maže foi lançado em 1976 pela Midway, e Maž Craže, em 1978 pela Atari. Ambos possuem a mesma dinâmica: "um jogo de labirinto onde um jogador tenta chegar à saída do labirinto antes que o adversário, seja o computador ou outro jogador, o faça” (AMAZING, 2006).

Utilizando o emulador ${ }^{40}$ Stella ${ }^{41}$, tivemos a chance de jogar Maz̧e Craze, como podemos ver na imagem a seguir. Cada nível do jogo consiste num labirinto diferente e, assim como em Amazing Maže, os labirintos criados pelo jogo são do tamanho da tela, de modo que os jogadores possuem

40 Emuladores são softwares que simulam um tipo de computador ou de equipamentos como celulares e calculadores, permitindo que softwares feitos para esses equipamentos rodem em outro tipo de computador. Exemplo: com o emulador Stella, é possível rodar jogos feitos para os consoles da Atari num computador PC.

41 Disponível para download em http://stella.sourceforge.net. 
visão total do mesmo.

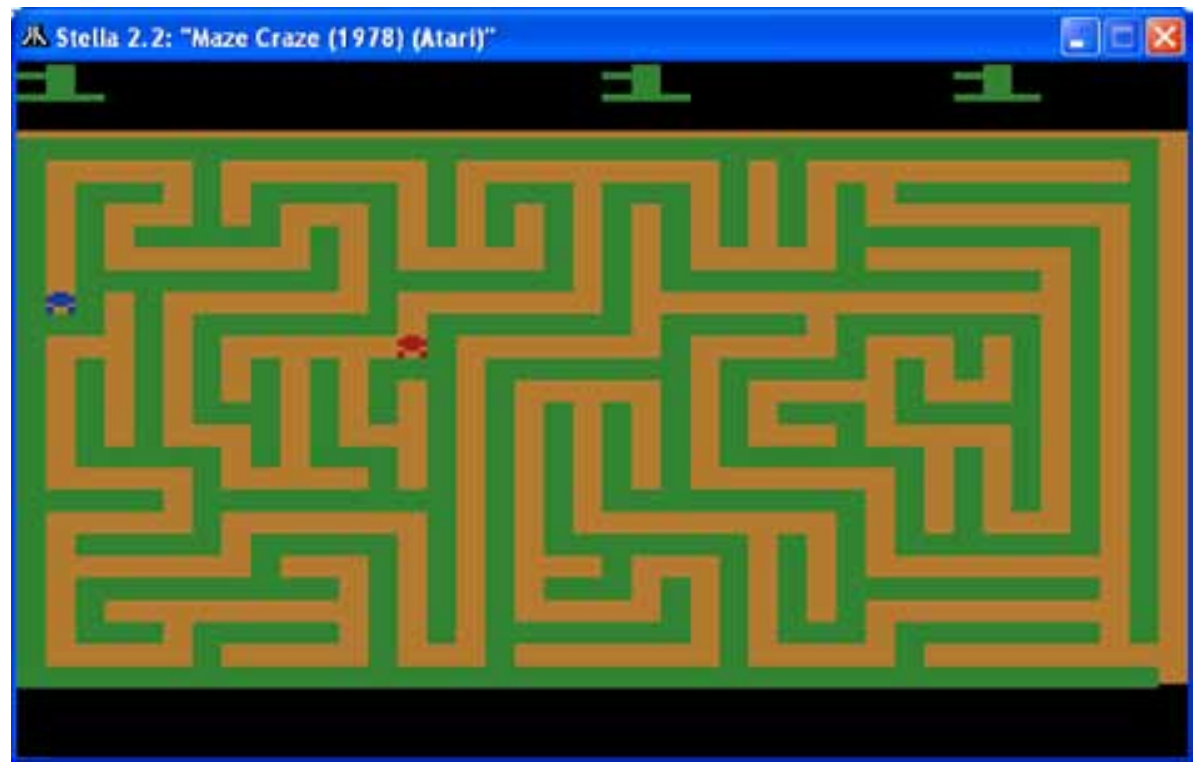

Ilustração 8. Um dos labirintos de Maz̧e Craz̧e. Jogo sendo executado pelo emulador Stella, em um computador atual.

\subsubsection{Tank}

Tank foi lançado em pela Kee Games em 1974. Nele, dois tanques de guerra se enfrentam em meio a diversos blocos que atuam como obstáculos ao deslocamento dos tanques e aos seus disparos (TANK, 2006). Apesar do cenário do jogo ser descrito, por diversos autores, como um labirinto, o seu desenho não é o de um labirinto tradicional. Em compensação, a dificuldade de deslocamento pelo espaço e a possibilidade de esconder-se do adversário aproximam o jogo da experiência do labirinto.

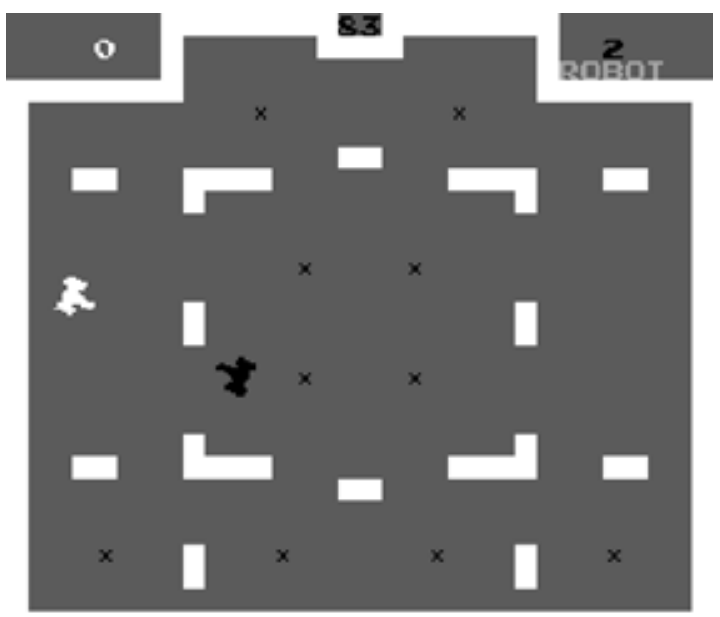

Ilustração 9. Imagem de Ultratank $k^{42,}$ rodando sob emulação.

42 Não conseguimos obter o jogo Tank original, apenas de versões lançadas posteriormente. 


\subsubsection{Dig Dug}

Dig Dug foi desenvolvido pela empresa japonesa Namco e lançado em 1982. De acordo com a descrição de De Maria e Wilson,

Dig Dug era um rapaz que gostava de cavar túneis e erradicar pragas usando a sua bomba portátil. A bomba literalmente explodiria os inimigos de Dig Dug como se eles fossem balões até que eles explodissem. Obviamente, para obter pontos extras por sua esperteza, você poderia atrair alguns de seus inimigos até que eles estivessem embaixo de uma pedra, cuja queda você provocaria no momento adequado. $O$ verdadeiro truque consistia no fato de que os seus inimigos possuíam um modo de movimentação fora dos túneis, que geralmente consistiam em obstáculos ao desavisado Dig Dug.

(DE MARIA; WILSON, 2003, p. 83. Tradução nossa) ${ }^{43}$

Como, no desenrolar do jogo, túneis são cavados pelo jogador, e estes se cruzam, os dois autores relacionam os desenhos formados pelos túneis com labirintos, chegando a dizer que Dig Dug "era um jogo do tipo faça-o-seu-próprio-labirinto".
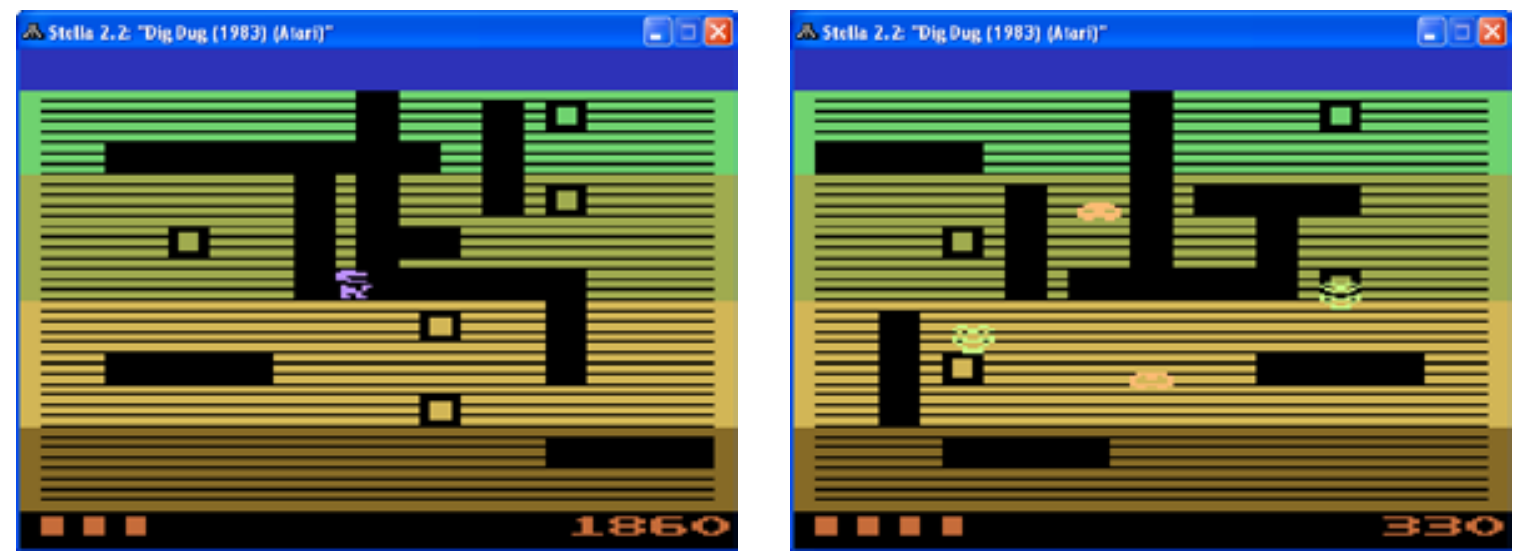

Ilustração 10. Duas imagens de Dig-Dug, versão para console Atari, rodando em emulador. À esquerda, o final de um dos primeiros níveis do jogo, onde resta apenas o personagem do jogador na tela, com os túneis cavados para perseguir seus inimigos, que podem ser vistos na imagem à direita.

Para nós, este jogo é especialmente importante, na medida em que o procedimento que ele pede do jogador é muito próximo do que é solicitado ao interator de um dos trabalhos que compõe o projeto PacMan e o Minotauro ${ }^{44}$, chamado PacManDRAW, por nós desenvolvido entre 2003 e 2004, anteriormente à realização desta dissertação.

43 Texto original em inglês: Dig Dug himself was a little guy who liked to tunnel underground and do some vermin eradication by means of his handy-dandy pump weapon. The pump would literally blow Dig Dug's enemies up like balloons until they popped. Of course, for extra cleverness points, you could lure a few pursuing Pookas and Fygars under a rock, which you conveniently caused to fall at just the right time. The real trick was that your enemies had a way of moving around without tunnels, which often means curtains for the unwary Dig Dug.. 

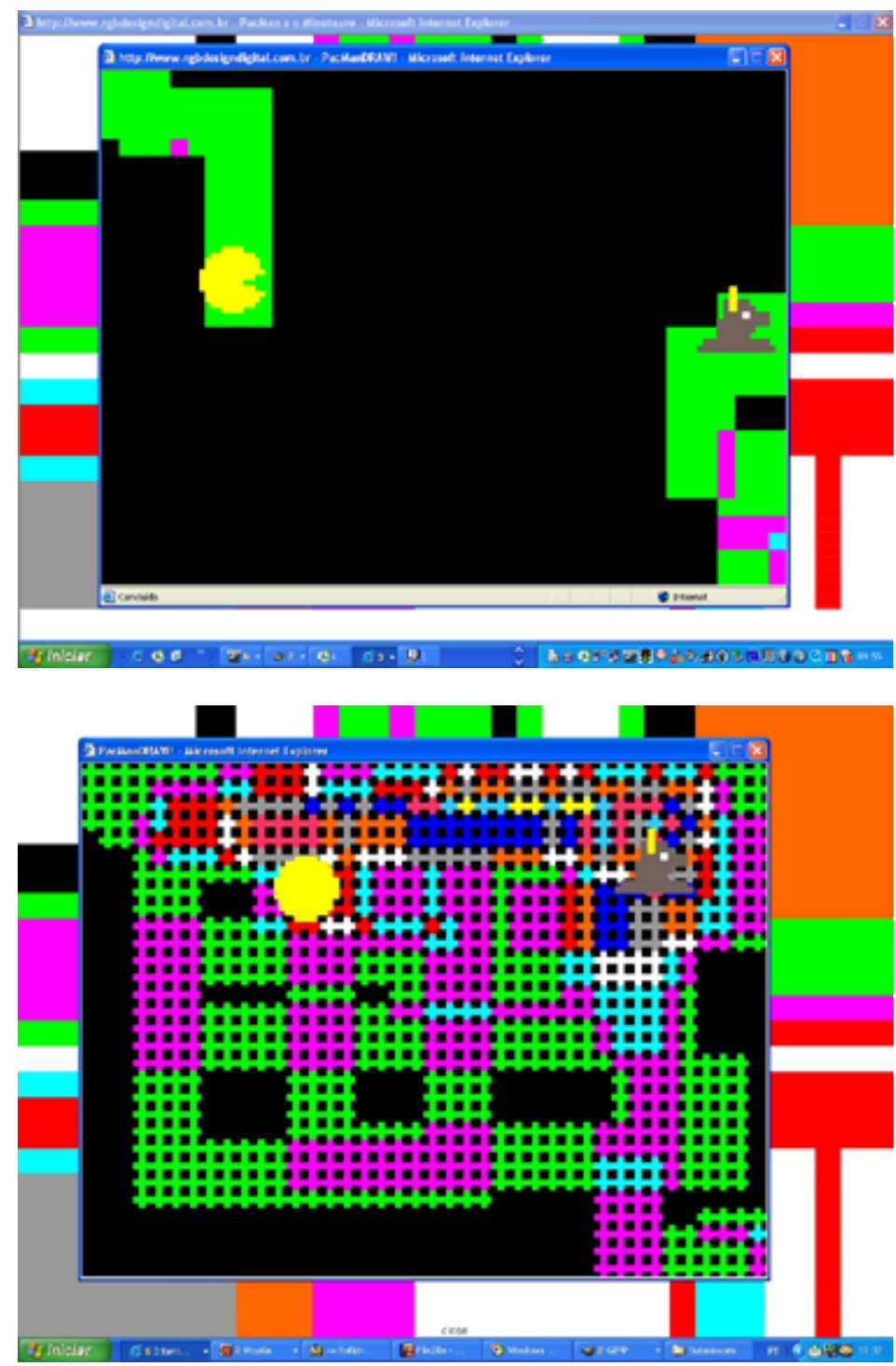

Ilustração 11. Imagens de PacManDRAW!

Neste trabalho, o jogador controla um dos personagens (o PacMan ou o Minotauro) e move-o pela tela. Cada personagem tem a propriedade de alterar a cor do espaço que percorre, de forma que, após alguns minutos de interação com o trabalho, temos a formação de uma imagem multicolorida na tela.

\subsubsection{PacMan}

PacMan foi desenvolvido pela empresa japonesa Namco, sendo que o personagem foi criado pelo designer Toru Iwatani, funcionário da Namco. Lançado em 1980, tornou-se o jogo do tipo arcade mais vendido da história, com mais de 100.000 máquinas vendidas (KENT, 2001, p. 143). Até então, o jogo mais vendido era Atari Asteroids, com 70.000 cópias. Parte do seu sucesso explica-se 

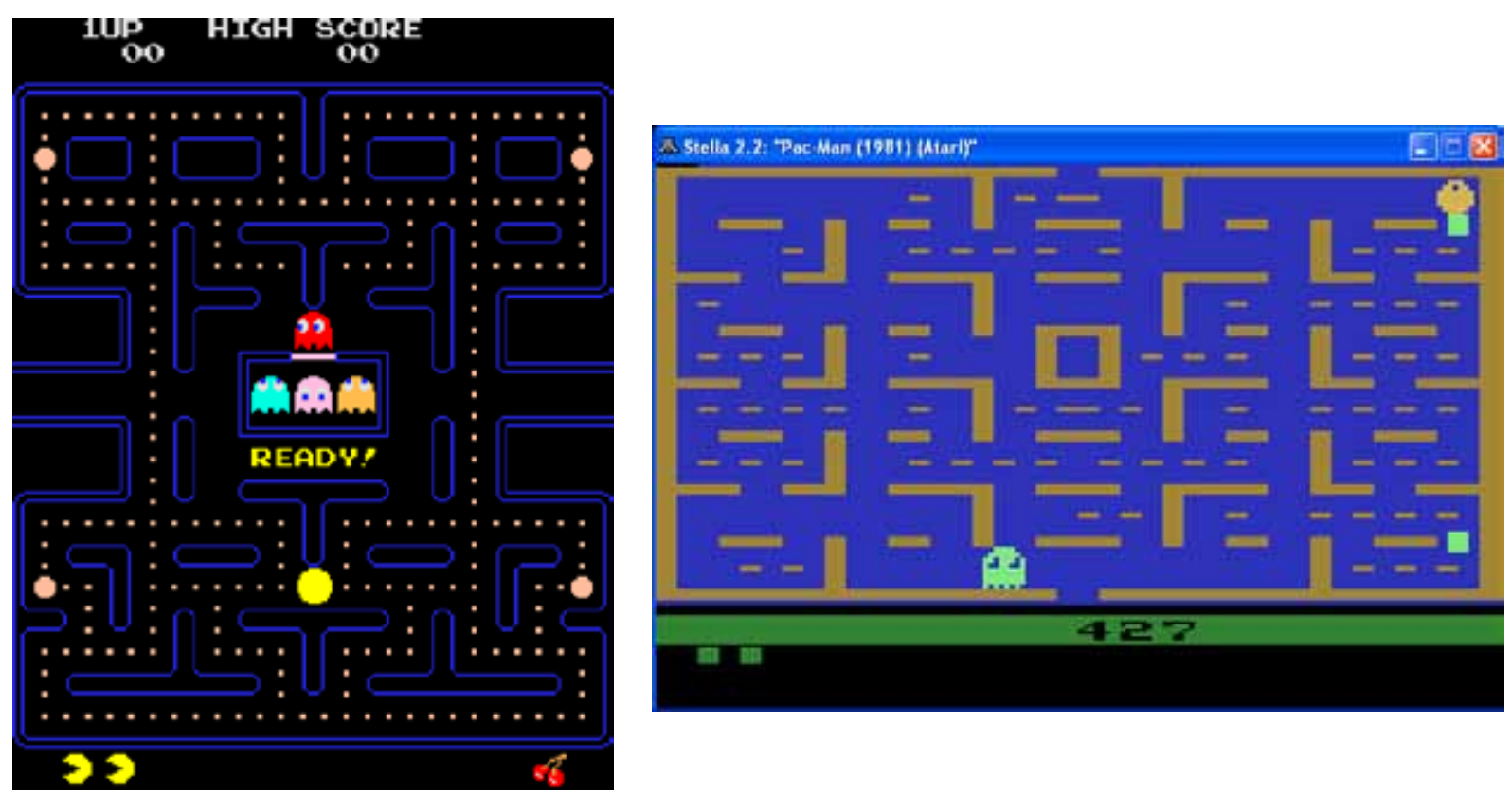

Ilustração 12. Imagens de PacMan. À esquerda, tela da versão original, em arcade, de PacMan. ${ }^{45}$ À direita, versão para console Atari, rodando sob emulação.

O mecanismo do jogo é descrito a seguir:

Após escutarem a música do jogo, os jogadores passam a guiar o PacMan num labirinto, comendo pontos, enquanto precisam tomar cuidado para não se aproximarem demais dos quatro fantasmas Blinky, Pinky, Inky e Clyde (cada um com diferentes graus de fome), que saem de uma gaiola no meio da tela e que eliminarão a vida do nosso pequeno amigo amarelo caso consigam tocá-lo. Em cada canto do tabuleiro retangular, há um ponto muito grande que, quando comido, deixará os monstros azuis por alguns instantes, durante os quais a situação se inverte e o PacMan pode comer os fantasmas, deixando apenas os aparentemente indigeríveis olhos, que voltam para a gaiola para reencarnarem como novos fantasmas. Em cada tela, um brinde aparece para o jogador embaixo da gaiola dos fantasmas, na forma de uma fruta ou sino ou algum outro símbolo esperando a sua vez de ser devorado. O jogo é enganosamente simples, sendo necessário apenas um joystick de quatro posições para guiar o PacMan pelo labirinto, mas, a cada nível, os fantasmas tornam-se mais rápidos e o tempo de vulnerabilidade, em que eles estão azuis, menor. A tensão cresce com um efeito sonoro constante, que se torna mais agudo conforme o jogador joga. (HUNTER, 2003. Tradução nossa) ${ }^{46}$

45 Fonte: Wikipedia, http://en.wikipedia.org/wiki/Image:Pac-man.png.

46 Texto original em inglês: After the distinctive theme music plays, players find themselves guiding 'puckman' around a single maze eating dots, while avoiding the four ghosts 'Blinky', 'Pinky', 'Inky' and 'Clyde' (each with varying levels of hunting skills), who escape from a cage in the middle of the screen and will end our little yellow friend's life if they touch him. In each corner of the square playfield is a large dot that when eaten will turn the ghosts blue for a brief period, during which time the tables turn and 'puck' can eat the ghosts, leaving only the apparently indigestible eyes which make their way back to the cage for reincarnation into another ghost. During every screen a treat appears for the player under the ghost-cage, in the form of fruit or a bell or some other symbol waiting to be devoured. The game is deceptively simple, with only a four-position joystick needed to guide 'pac-man' around the maze, but with each successive screen the ghosts get faster and their time of blue-invulnerability less. Tension is added with a steady whining sound effect that increases in pitch as the game is played. 
Diversas variantes podem ser encontradas na Internet, tendo sido desenvolvidas pela $\mathrm{Na}$ mco, por empresas licenciadas, ou por desenvolvedores independentes, sem autorização. As mais comuns são a versão feminina do PacMan, Ms. PacMan, e as versões que apresentam labirintos tridimensionais.

Apesar de sua importância histórica (poucos jogos eletrônicos são tão associados ao labirinto), o jogo PacMan terá uma presença discreta nesta pesquisa, em decorrência de já termos desenvolvido diversos trabalhos a partir do mesmo (PacMan $1.0^{47}$ e os trabalhos que compõem o projeto PacMan e o Minotauro). Devemos observar que foi o desejo de ampliar o estudo da presença do labirinto para outros jogos e de trabalhar com outras formas de representação espacial que motivaram a elaboração do projeto de pesquisa ao qual nos dedicamos aqui.

\subsubsection{Jogos com rolagem em um eixo}

Na maioria dos jogos, o espaço de ação não é representado totalmente na tela; apenas parte dele é visível, e os jogos oferecem mecanismos para que o jogador navegue pelo espaço, fazendo com que algumas áreas e elementos se tornem visíveis, enquanto outros somem do campo de visão. A rolagem foi um dos primeiros destes mecnismos. Foi utilizada pela primeira vez num jogo eletrônico em 1978, em Football, jogo arcade criado pela Atari (WOLF, 2002, p. 58).

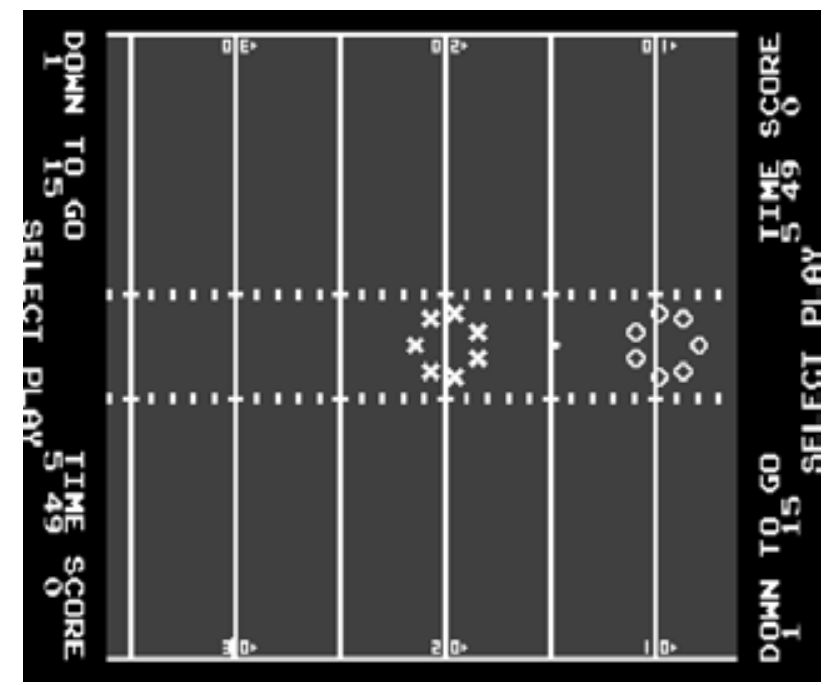

Ilustração 13. Imagem de Football, jogo da Atari, rodando sob emulação. Os Xs e Os representam os jogadores dos dois times adversários.

Jogos de rolagem dão uma ênfase variável ao espaço fora da tela. Em alguns casos, a

47 http://www.andreithomaz.com/pacman 
disposição dos objetos encontrados neste espaço é sempre a mesma, permitindo que o jogador saiba o que o aguarda, ainda que não possa vê-los. Esses jogos fazem um uso ativo do espaço não-visível, utilizando-o para construir uma previsão por parte do jogador e, às vezes, criando a ilusão de uma faixa de espaço infinita, onde o jogador poderia se deslocar de forma contínua, desde que ele fosse bom o suficiente para não perder o jogo. Poder conhecer cada vez mais o espaço do jogo pode ser, por si só, uma forma de recompensa, assim como passar para níveis mais altos é em outros jogos.

(WOLF, 2002, p. 57. Tradução nossa) $)^{48}$

Analisando alguns dos jogos que empregam este tipo de espaço (Defender, Super Mario), podemos perceber dois tipos de uso da rolagem: no primeiro, o jogo privilegia o movimento em um determinado sentido (isto é, se o jogo possui rolagem vertical, o jogador se movimenta prioritariamente para cima ou para baixo, sem que voltar faça sentido); já no segundo, o jogador deve ir e voltar até completar um determinado objetivo.

Por exemplo, na primeira versão de Super Mario, lançado pela Nintendo em 1983 (DE MARIA, WILSON, 2003, p. 89), o movimento do personagem principal é sempre para a direita e o jogador não pode rolar a tela para a esquerda. O objetivo do jogo consiste em completar cada nível no menor tempo possível, coletando a maior quantidade de itens e evitando obstáculos e inimigos. A posição dos itens não varia, o que permite que, aos poucos, o espaço de cada nível seja conhecido pelo jogador e que ele melhore o seu desempenho.
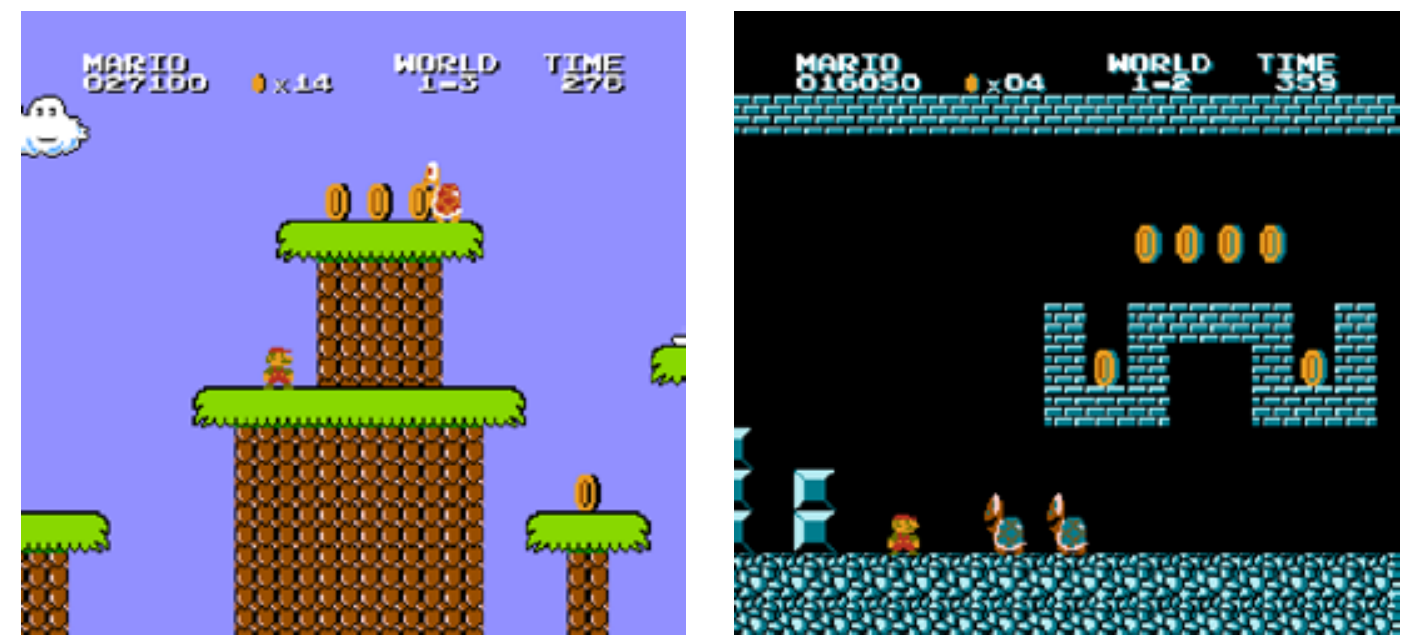

Ilustração 14. Imagens de Super Mario, onde o jogador se movimenta, prioritariamente, para a direita. Jogo rodando sob emulação.

48 Texto original em inglês: Scrolling games vary in their emphasis on the importance of off-screen space. In some games, the configurations of objects found in this space are always the same, allowing a player to anticipate what lies ahead in the game, off-screen but approaching. The games make active use of off-screen space, using it to build a player's anticipation and sometimes creating the illusion of an endless track of space which players could continue moving through, provided they were good enough at the game to keep going. Seeing more and more of this "track" can itself be a kind of reward, just as moving to higher levels is in other games. 
Já em Defender, lançado pela Atari em 1980 (DE MARIA, WILSON, 2003, p. 61), a nave controlada pelo jogador deve mover-se horizontalmente, em ambas as direções, para aniquilar as naves alienígenas que invadem a cidade onde se desenrola o jogo. Um elemento importante é a tela de radar que mostra a localização das naves alienígenas e que cumpre a função de mapa, apresentando uma visão geral do espaço do jogo.
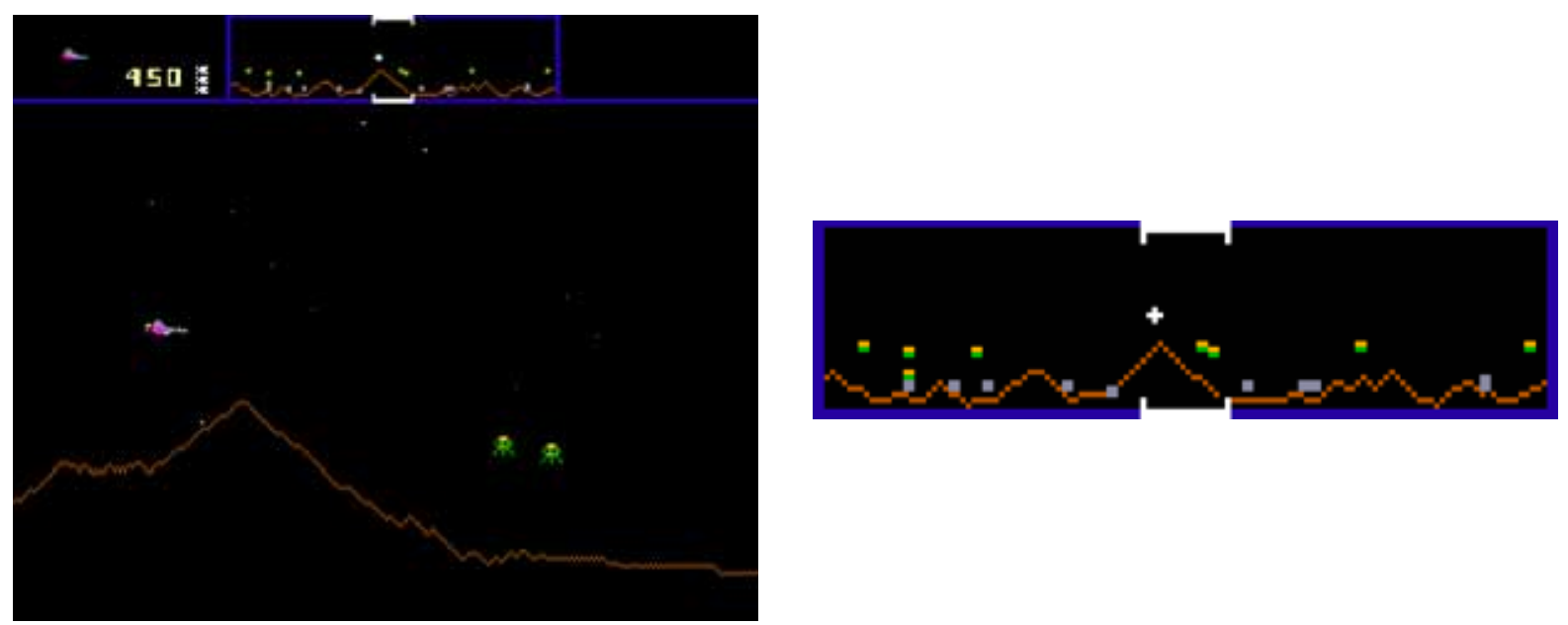

Ilustração 15. À esquerda, tela de Defender, versão para Atari 2600, rodando sob emulação, onde podemos perceber a tela de radar, ampliada à direita.

Pelo fato dos movimentos do jogador serem muito restritos neste tipo de construção do espaço, a presença de labirintos, ou de elementos que possamos chamar de labirínticos, é muito tímida; não encontramos nenhum jogo que pudéssemos incluir aqui. Dentro de cada nível, os percursos são lineares na maior parte do tempo, os espaços são contínuos e há poucas chances do jogador se desorientar ou ter a sensação de estar num espaço complexo, sem ter uma noção de como ele é, globalmente. Só teremos uma experiência mais labiríntica se considerarmos o conjunto de percursos ao longo de todos os níveis do jogo. Neste caso, encontraremos configurações espaciais menos lineares e de apreensão mais difícil.

\subsubsection{Jogos com rolagem nos dois eixos}

Alguns anos após o lançamento de Football e de outros jogos com rolagem em um eixo, a indústria de jogos começou a criar jogos com rolagem nos dois eixos da tela, horizontal e vertical, podendo representar a visão de topo ou, então, a visão frontal do cenário do jogo. Analisaremos aqui um caso citado por Wolf, The Dark Chambers, lançado pela Atari em 1988 (WOLF, 2002, p. 
58), e o primeiro jogo da série Zelda, The Legend of Zelda, criada por Shigeru Myiamoto, o principal designer de jogos da Nintendo (DE MARIA e WILSON, 2003, p. 238).

\subsubsection{The Dark Chambers}

Em The Dark Chambers, o personagem controlado pelo usuário move-se por um cenário escuro, lembrando uma masmorra, povoado por fantasmas e prisioneiros que devem ser mortos pelo jogador, sob pena deles o ferirem, caso consigam encostar nele. Ao mesmo tempo, o jogador deve coletar diversos itens que estão dispostos ao longo do caminho, como chaves e bombas.

Apesar de Wolf citar este jogo como sendo um exemplo de rolagem dos dois eixos, preferimos vê-lo como um meio termo entre os jogos com rolagem em apenas um eixo e os jogos com rolagem nos dois eixos. Isso porque o jogo possui rolagem no eixo vertical, mas, no eixo horizontal, temos uma passagem descontínua entre um cenário e outro. Ou seja, é mais adequado dizer que, horizontalmente, temos cenários adjacentes, e não um cenário contínuo.
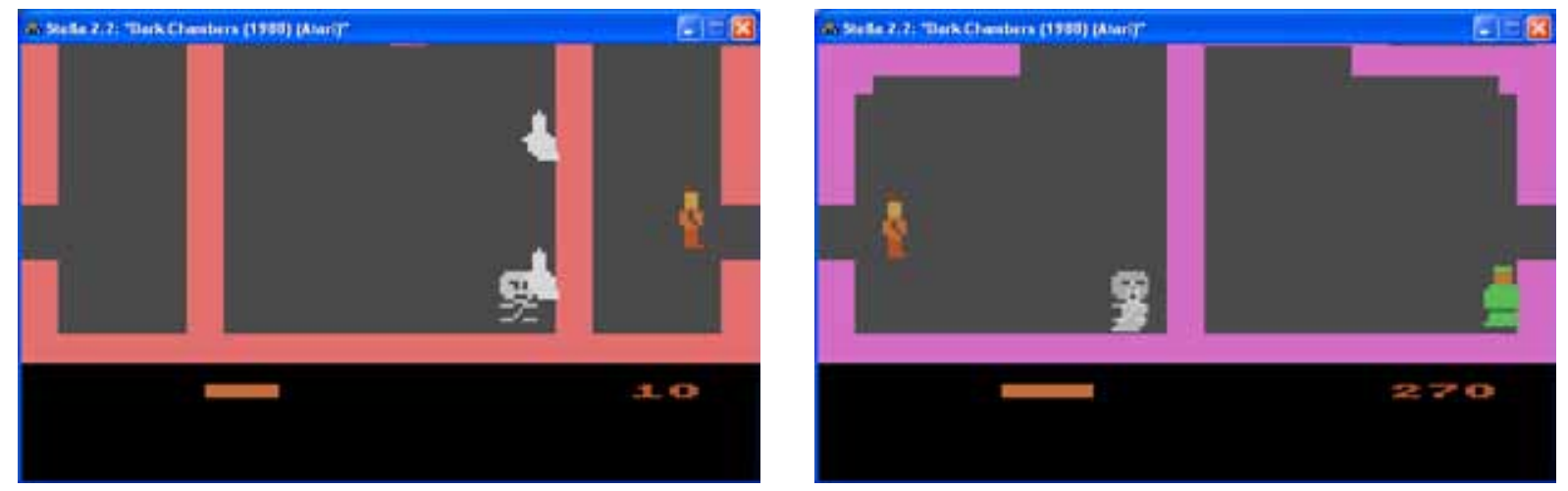

Ilustração 16. Movimento do usuário entre dois espaços, no sentido horizontal: ao deslocar-se um pouco para a esquerda, o usuário (personagem marrom) move-se para outra sala, sem que o jogo "role", de forma contínua, o cenário, de forma a acompanhar o movimento do jogador. É interessante observar que o jogo utiliza a cor das paredes para marcar a mudança de espaço.

Como é possível ver nas figuras acima, as salas pelas quais o jogador se move são limitadas por paredes, e nem sempre há portas comunicando duas salas adjacentes. Assim, em muitos casos, o jogador não consegue perceber, imediatamente, como chegar à sala ao lado. Ele pode ver uma chave, ou outro objeto que lhe parecerá importante para o prosseguimento do jogo, e não ter como chegar a ele. Isto faz com que o espaço do jogo ganhe aspectos labirínticos, à medida em que o percurso torna-se mais e mais difícil, sem que o caminho entre duas salas seja imediatamente perceptível ao jogador. 


\subsubsection{The Legend of Zelda}

Este jogo foi lançado em 1986 pela Nintendo. Nele, o jogador comanda o personagem Link por um vasto território, com o objetivo de resgatar a princesa Zelda. The Legend of Zelda foi o primeiro de uma série de jogos com esses personagens principais. Esta série possui alguns dos jogos mais vendidos pela Nintendo, e permanece em desenvolvimento.

No primeiro jogo da série, que é o que será analisado aqui, nós temos representada na tela a visão de topo do espaço do jogo, com os personagens sendo representados de forma um pouco inclinada. A rolagem da tela é contínua em todas as direções. Apesar do percurso de Link (personagem controlado pelo jogador) ser cheio de obstáculos, não é apenas isto que faz com que o jogo tenha características labirínticas. O que mais aproxima o jogo do labirinto são as portas que dão acessos a outros mundos, chamados dungeons, e o fato do jogador poder ir e voltar entre o mundo principal e os dungeons (entretanto, não entre um dungeon e outro). Isto é, o percurso do jogador não se dá de forma linear, como ocorre com os níveis, normalmente encontrados em jogos eletrônicos, nos quais o jogador só pode percorrê-los numa determinada ordem. Ao contrário, em Zelda, é possível completar o jogo percorrendo os dungeons em diversas ordens diferentes.

Como o espaço do mundo principal é vasto, o jogador de Zelda percorre longas distâncias até identificar os portais que dão acesso a cada um dos dungeons, e ainda precisa reunir as informações e objetos encontrados em cada um dos dungeons para poder descobrir quais devem ser os seus próximos passos. Por exemplo: para conseguir abrir uma porta em um dungeon específico, é preciso ter consigo um objeto obtido em outro dungeon. Como o jogo não obriga o jogador a seguir uma determinada ordem em sua caminhada, isto faz com que o esforço de orientação, por parte do jogador, tenha que ser consideravelmente maior do que num jogo dividido em níveis que são percorridos de forma seqüencial e obrigatória.
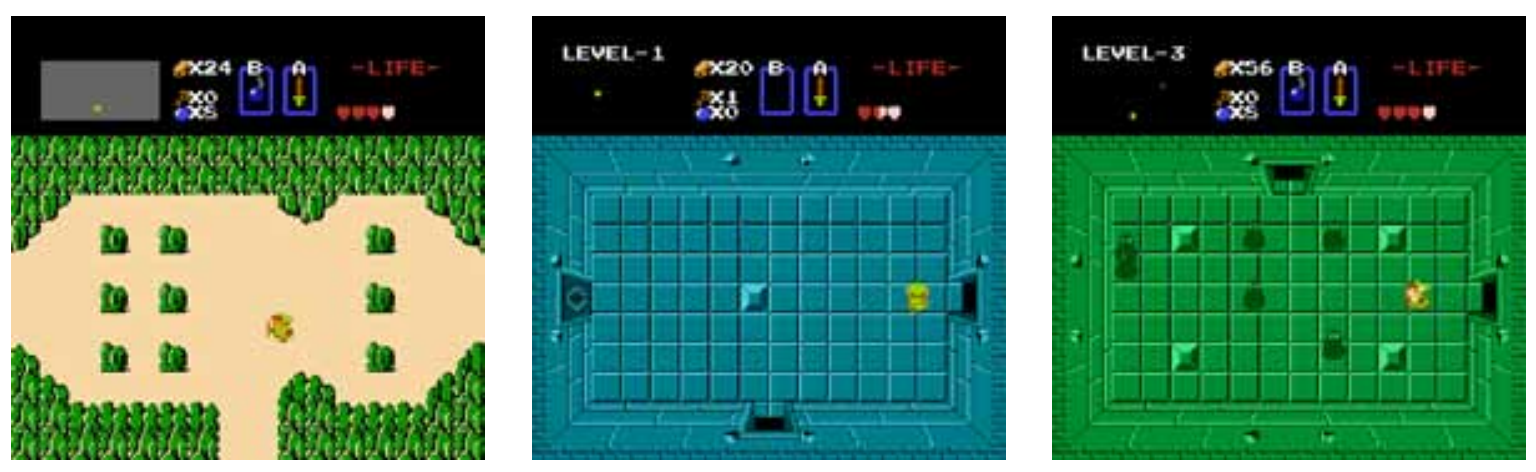

Ilustração 17. O mundo principal (à esquerda) e dois dos dungeons do primeiro jogo da série de Zelda 
2.1.4.3 O uso de portais

Tanto The Dark Chambers quanto The Legend of Zelda fazem uso de portais que ligam diferentes níveis / seções (no caso de Zelda, chamadas de dungeons) do jogo entre si. E nestes dois jogos o percurso pelos diferentes níveis não precisa ser cumprido numa seqüência fixa, tal como ocorre na maioria dos jogos eletrônicos, de modo que, não raramente, o jogador precisará avançar até um determinado nível/mundo, executar algum tipo de ação, e voltar para algum nível/mundo visitado anteriormente, para continuar ali a sua missão. Assim, além de um espaço que pode ser mapeado pelo jogador (isto é, um espaço que possui uma planta, com área continua), também temos uma série de caminhos que também pode ser mapeada, mas não mais como uma planta, mas sim como um grafo, uma estrutura de nós, que não pode mais ser representada por uma "vista de topo", já que o uso de portais implica na alteração das distâncias (eles funcionam como uma espécie de teletransporte).

2.1.5 Espaços adjacentes, exibidos um de cada vez

Aqui se classificam os jogos em que

espaços ou cômodos adjacentes são exibidos como uma série de telas que não se sobrepõem, que levam de uma a outra diretamente, sem qualquer forma de rolagem (...) Se o personagem controlado pelo jogador se move para fora da tela numa direção, a tela muda e o personagem reaparece no lado oposto da tela; a direção do movimento é preservada, e as telas são vistas como sendo imediatamente adjacentes.

(WOLF, 2002, p. 59. Tradução nossa) ${ }^{49}$

Ainda de acordo com Wolf, o primeiro jogo a utilizar espaços adjacentes, exibidos um por vez, foi o jogo Adventure, lançado em 1978 pela Atari, que utilizava doze espaços adjacentes uns aos outros. Além disso, também havia telas que representavam espaços dentro de outros espaços, como o interior dos castelos. Ao entrar num deles, o jogador era transportado para outra tela, representando o interior do castelo, numa mudança de escala (isto é, o espaço do castelo, que upava alguns pixels de largura e de altura, passava a ter as dimensões da tela inteira) que pode ser vista como próxima à realizada pelo efeito de zoom no cinema.

49 Texto original em inglês: adjacent spaces or rooms are displayed as a series of nonoverlapping static screens which cut directly one to the next without scrolling (...) As the player's on-screen character moves off-screen in one direction, the screen changes instantly and the character reenters on the opposite side of the screen; the direction of screen movement is conserved, and the screens are seen as being immediately adjacent to one another. 

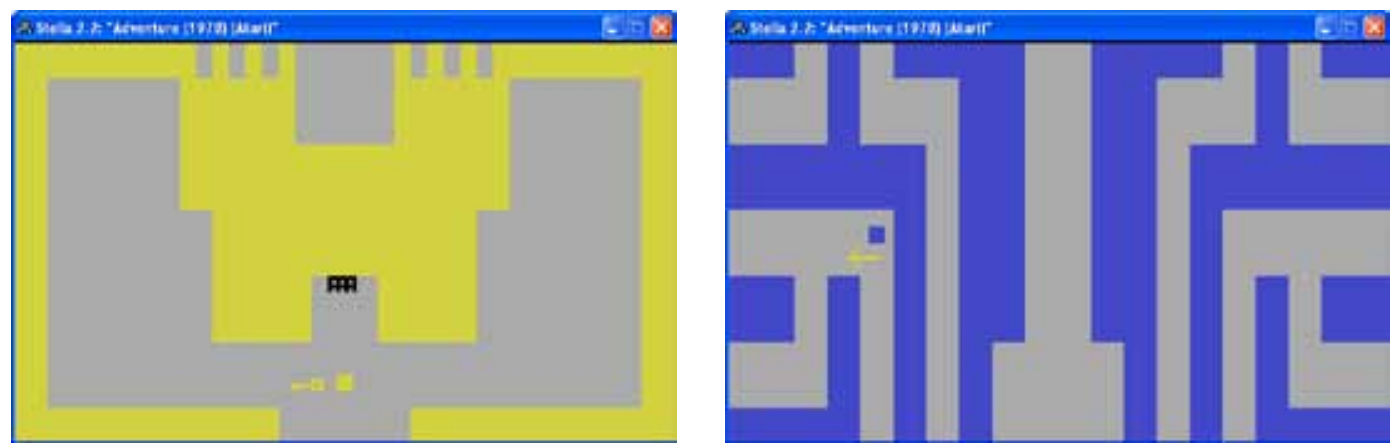

Ilustração 18. Imagens de Adventure
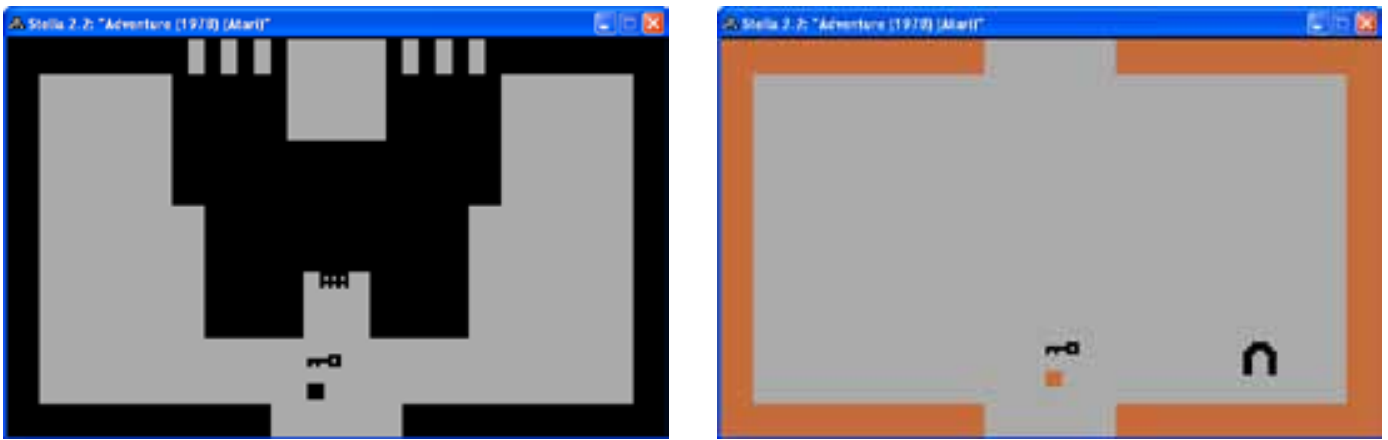

Ilustração 19. Jogador entrando num castelo (à esquerda) e no interior do mesmo (à direita)

Além de termos um labirinto presente na tela de forma explícita, nas seções com paredes azuis do jogo, a experiência do jogador de Adventure também é labiríntica pelos mesmos motivos dos jogos baseados em texto: o jogador recebe informações locais (no caso de Adventure, ele vê apenas uma seção por vez) e, a partir delas, precisa montar o mapa, global, do espaço do jogo. Diversos jogadores de Adventure realizaram esta tarefa, literalmente, e disponibilizaram mapas do jogo da Internet: 


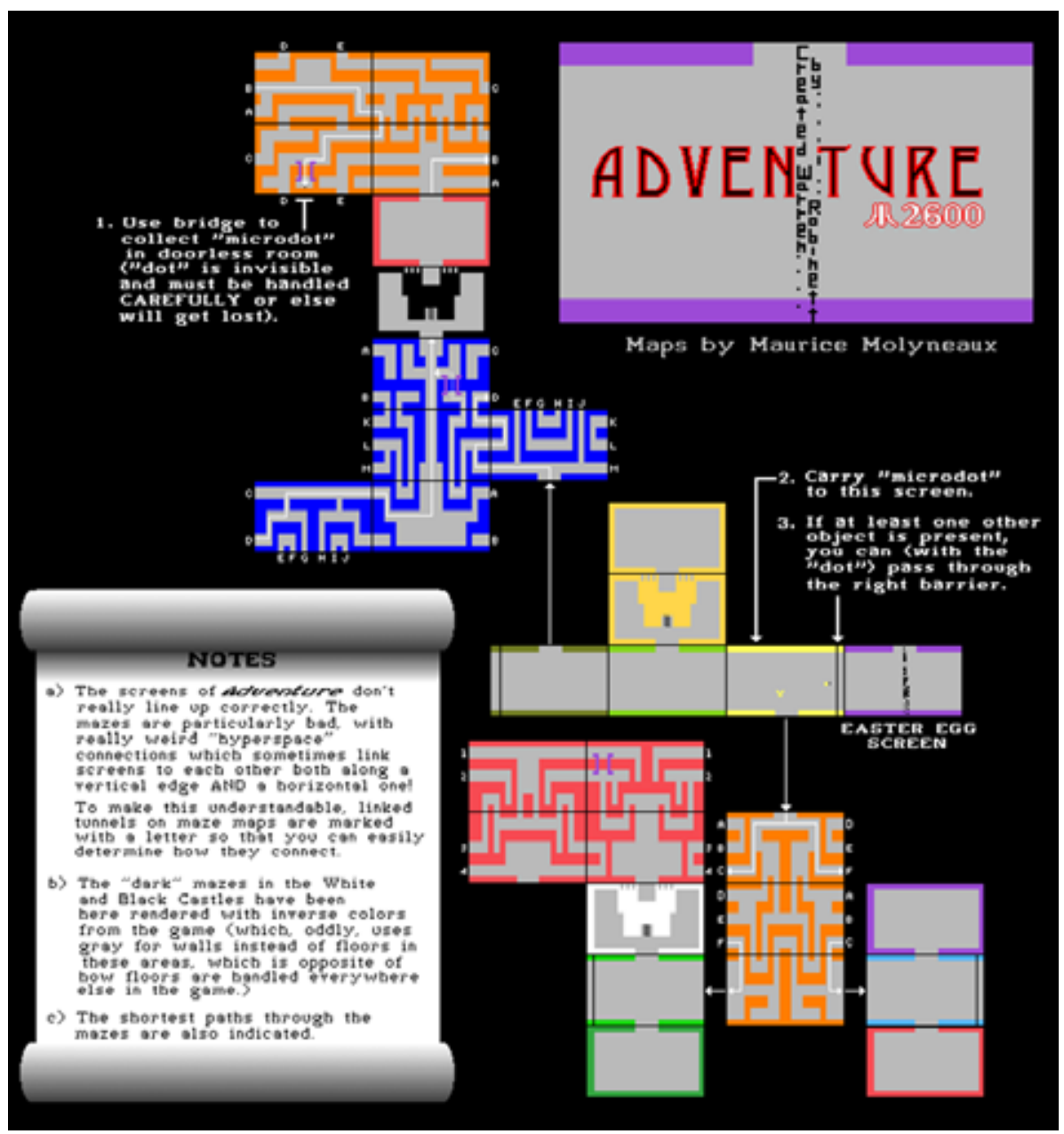

Ilustração 20. Um dos mapeamento dos espaços de Adventure

Além de Adventure, outro jogo que devemos mencionar aqui é Prince of Persia, finalizado em 1998 por Jordan Mechner e distribuído pela Broderbund (DE MARIA, WILSON, 2003, p. 292). Prince of Persia também divide o espaço em telas adjacentes, sem rolagem entre uma e outra tela, mas, ao contrário de Adventure, os cenários são exibidos frontalmente, sem o uso de vistas de topo. A narrativa do jogo se passa dentro do palácio do Sultão da Pérsia, que deixou o mesmo para participar numa guerra em território estrangeiro (PRINCE, 2006). Aproveitando-se da ocasião, o vizir Jaffar aprisiona a princesa, filha do Sultão e herdeira do trono, e lhe dá um ultimato: ou ela aceita se casar com ele, ou morrerá em uma hora. Este é o tempo de que dispõe o príncipe, controlado pelo jogador, para resgatar a princesa. 

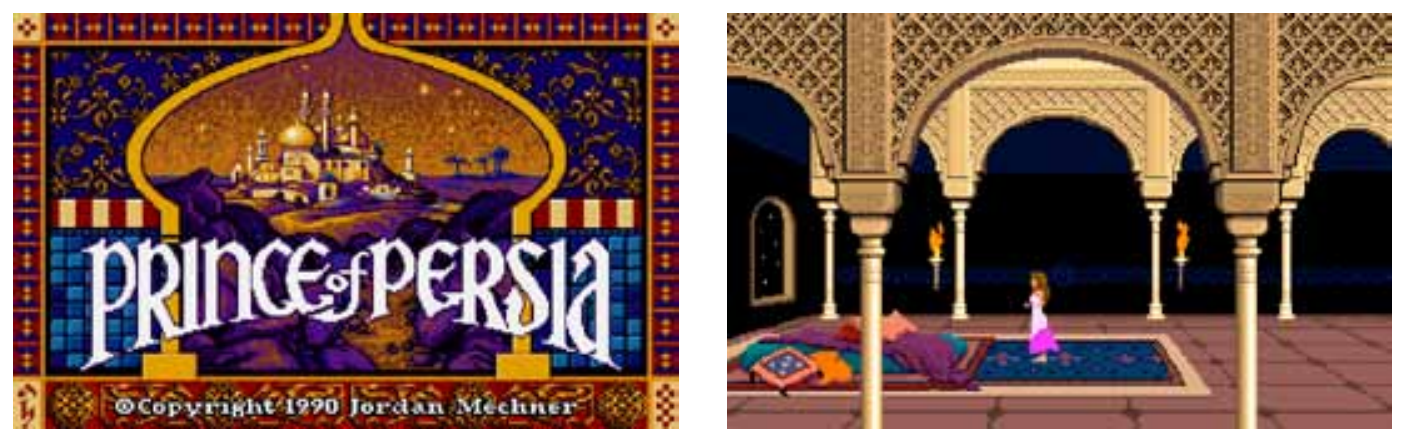

Ilustração 21. Imagens da abertura de Prince of Persia, no qual a narrativa do jogo é apresentada ao jogador

Os cenários do jogo são basicamente de dois tipos: masmorras (caracterizados por paredes azuladas) e o interior do castelo (que possui cor de areia).
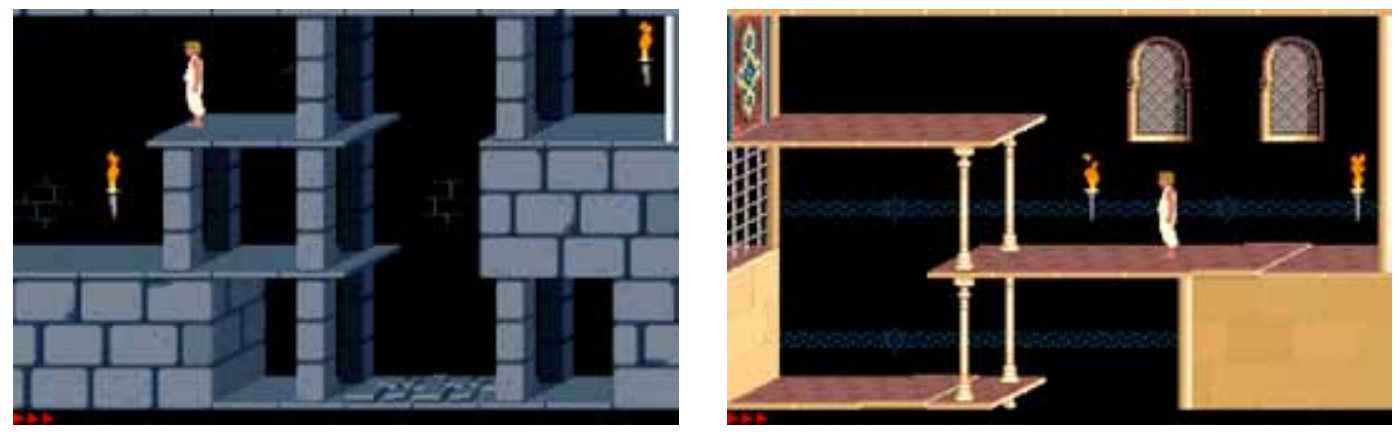

Ilustração 22. Os dois tipos de cenário de Prince of Persia

Não só o desenho dos caminhos dentro de cada nível lembra os labirintos, como também a série de obstáculos e inimigos que o príncipe deve enfrentar torna o caminho difícil e cria a sensação de se estar "andando em círculos", típica dos labirintos de múltiplos caminhos. Estas características fizeram deste jogo a base de um dos trabalhos por nós desenvolvidos no escopo desta dissertação, Prince of Persia: Estudos, que será descrito a partir da página 151.

2.1.6 Jogos com rolagem horizontal, com múltiplos planos

O espaço nestes jogos é criado através do uso de um conjunto de "planos sobrepostos, que se movimentam de forma independente, com o plano frontal contendo o personagem do jogador (e, geralmente, os elementos do cenário com os quais o personagem interage), enquanto os planos posteriores contém o fundo e são rolados numa velocidade menor que o plano frontal, criando a ilusão de profundidade”. (WOLF, 2002, p. 63). Este tipo de recurso também é conhecido como 
animação paralaxe (PARALLAX, 2007).

Como exemplos de jogos que utilizam rolagem horizontal com o uso de diversos planos, apresentamos os primeiros jogos da série Sonic e o jogo R-Type. Em Sonic The Hedgehog, primeiro jogo com o principal personagem da Sega, o jogador pode se deslocar nas duas direções, coletando objetos e encontrando inimigos no mesmo plano em que o jogador está. A direção principal do jogo ainda é para a direita, com o início de cada nível sempre à esquerda, e o final, sempre à direita. O fundo contém apenas um plano, que se movimenta de forma mais lenta que o plano frontal.
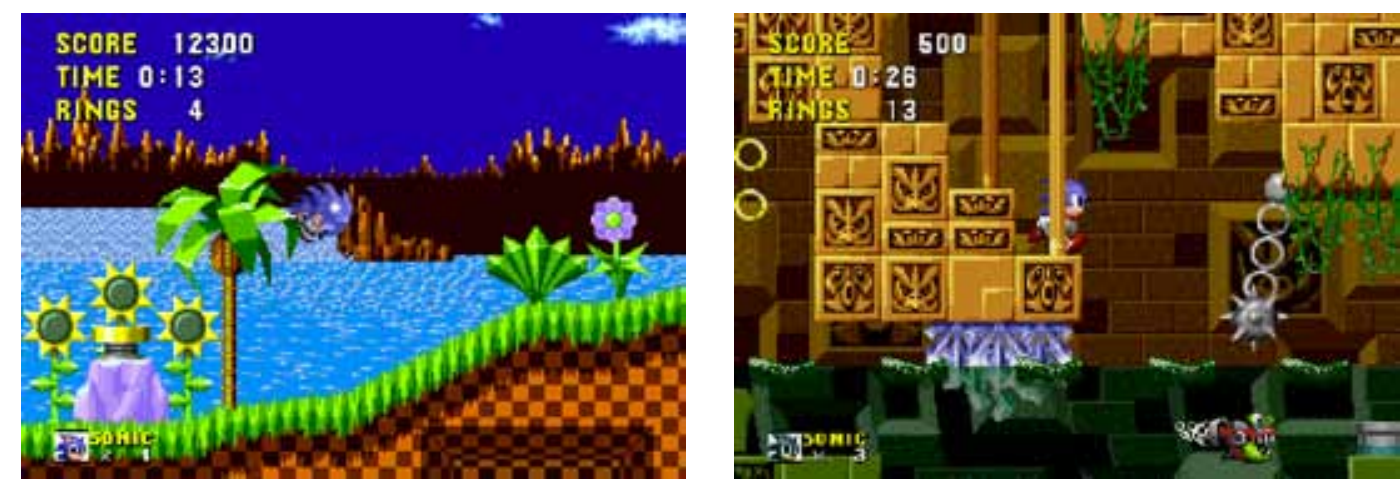

Ilustração 23. Imagens de Sonic the Hedgehog, rodando sob emulação

Já R-Type, lançado em 1987 pela empresa japonesa Irem (R-TYPE, 2006), utiliza o efeito de múltiplos planos de forma mais tímida. Neste jogo, a tarefa do jogador é controlar uma nave e atacar as naves inimigas. O cenário é composto por "camadas" de estrelas que movem-se em velocidades diferentes, criando a ilusão de profundidade.

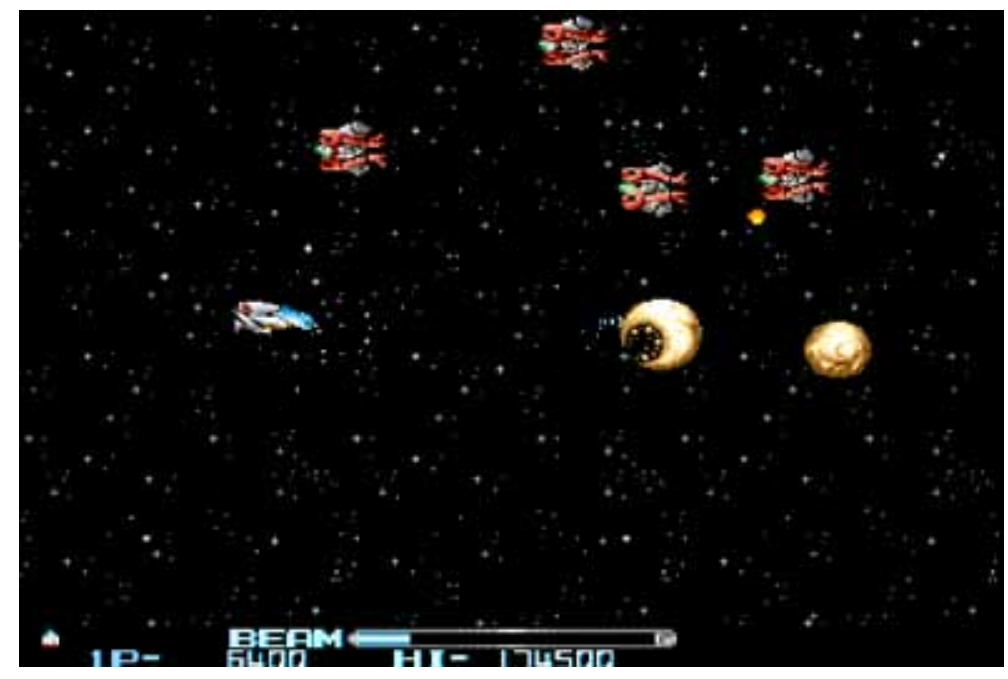

Ilustração 24. Imagem de R-Type II, rodando sob emulação

Assim como ocorre nos jogos com rolagem num único eixo, que não utilizam múltiplos 
planos, também neste caso o labirinto está pouco presente, principalmente pela simplicidade da movimentação do jogador no cenário do jogo.

2.1.7 Jogos como movimento no eixo $Z$ (para dentro e para fora da tela)

São os jogos em que o movimento se dá para “dentro” da tela e onde o cenário se movimenta bem mais que o personagem do jogador. Na maioria dos jogos deste tipo, o jogador controla um veículo em movimento (seja carro, nave espacial ou avião), que possui poucas possibilidades de movimento (ele pode virar à esquerda ou à direita mas, na realidade, é a movimentação do cenário que irá representar, visualmente, o deslocamento do jogador).
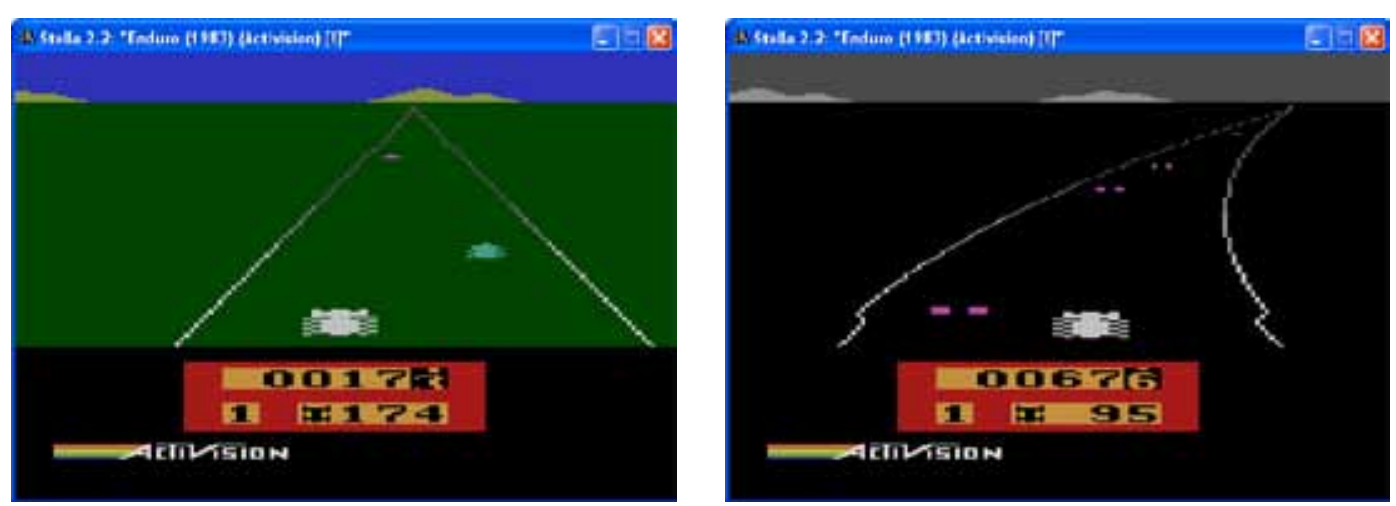

Ilustração 25. Imagens de Enduro, lançado em 1983 pela Activision para a plataforma Atari (ENDURO, 2006). O carro branco é o veículo controlado pelo jogador. Jogo rodando sob emulação.

Segundo Wolf, este tipo de representação do espaço foi "a que mais demorou para aparecer nos video games devido à dificuldade de representar o movimento dimensional que ele exigia objetos tornando-se maiores até que eles saiam do campo de visão" (WOLF, 2002, p. 63). Em jogos como S. T. U. N. Runner (S.T.U.N., 2006) e Enduro, nós temos o recurso do aumento de tamanho dos objetos à medida que o jogador avança.
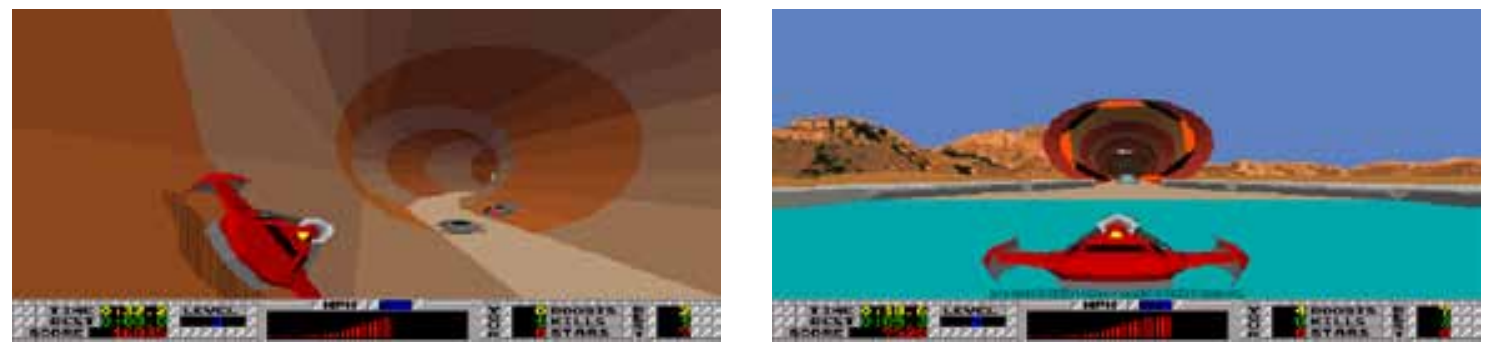

Ilustração 26. Imagens de S.T.U.N. Runner. Jogo sendo executado sob emulação.

Já em outros, como After Burner, lançado pela Sega em 1987 (AFTER Burner, 2006), o 
movimento é representado de forma mais primitiva, já que são poucos os objetos que aumentam de tamanho; pode-se dizer que temos uma sucessão de planos, com o objetivo de dar a sensação de profundidade, mas com menos resultado do que nos jogos em que os objetos também mudam de tamanho.
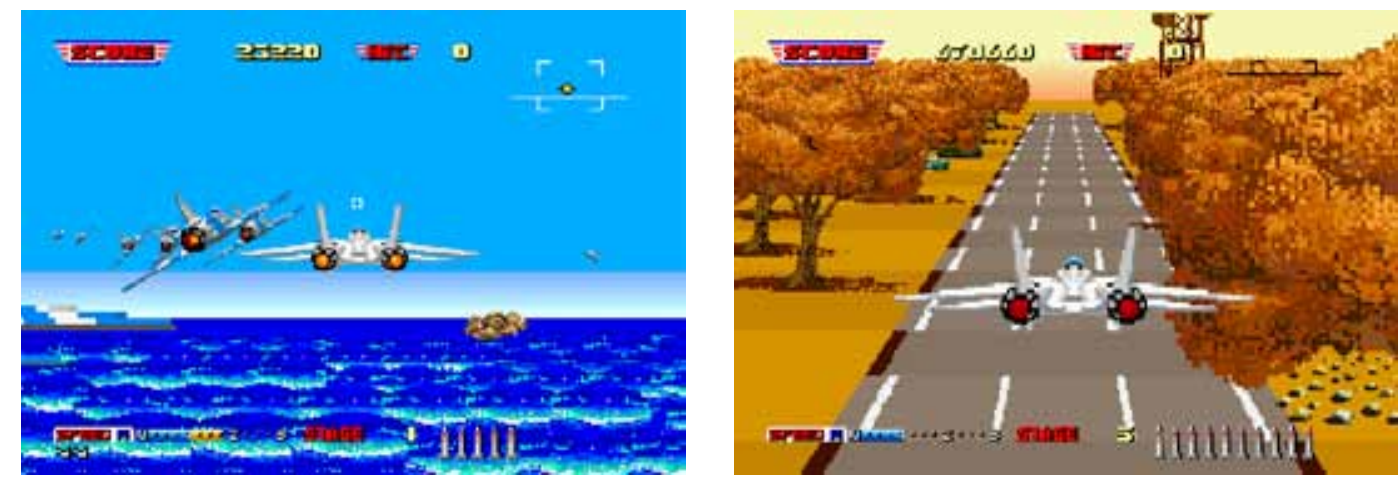

Ilustração 27. Imagens de After Burner II, rodando sob emulação.

Independentemente da forma como a movimentação do cenário é realizada (redimensionamento dos objetos ou sucessão de planos), a simplicidade da movimentação do usuário torna o espaço do jogo fácil de ser entendido (uma linha reta em que sempre se avança, na maioria dos casos), muito distante do labirinto.

2.1.8 Diversos espaços, não adjacentes, exibidos simultaneamente

Aqui, Wolf apresenta o caso de alguns jogos que apresentam dois pontos de vista diferentes, ao mesmo tempo, na tela. São jogos em que temos dois jogadores (sendo que o papel de um deles pode ser desempenhado pelo computador ou por uma pessoa) e em que os seus respectivos pontos de vista são exibidos na tela. Nas palavras de Wolf:

Enquanto cada um dos pontos de vista pode exibir qualquer um dos tipos de espaço citados neste texto, a combinação de múltiplos pontos de vista pode modificar o jogo de forma drástica, uma vez que a atenção do jogador se alterna entre dois pontos de vista. (WOLF, 2002, p. 64. Tradução nossa) ${ }^{50}$

Entre os exemplos citados por Wolf, está o jogo $S p y$ vs $S p y$, que também é pertinente aos

50 Texto original em inglês: While each of the viewpoints can contain any of the types spaces mentioned here, the combination of multiples viewpoints can make a very different game, since attention can be split between two points of view. 
nossos estudos ${ }^{51}$. A ação do jogo ocorre dentro dos muitos cômodos de uma embaixada, onde dois espiões (um controlado por cada jogador) procuram os objetos necessários para que eles possam fugir antes que o adversário consiga atingir o mesmo objetivo. Cada jogador pode preparar armadilhas para o outro espião, a fim de fazê-lo perder tempo.
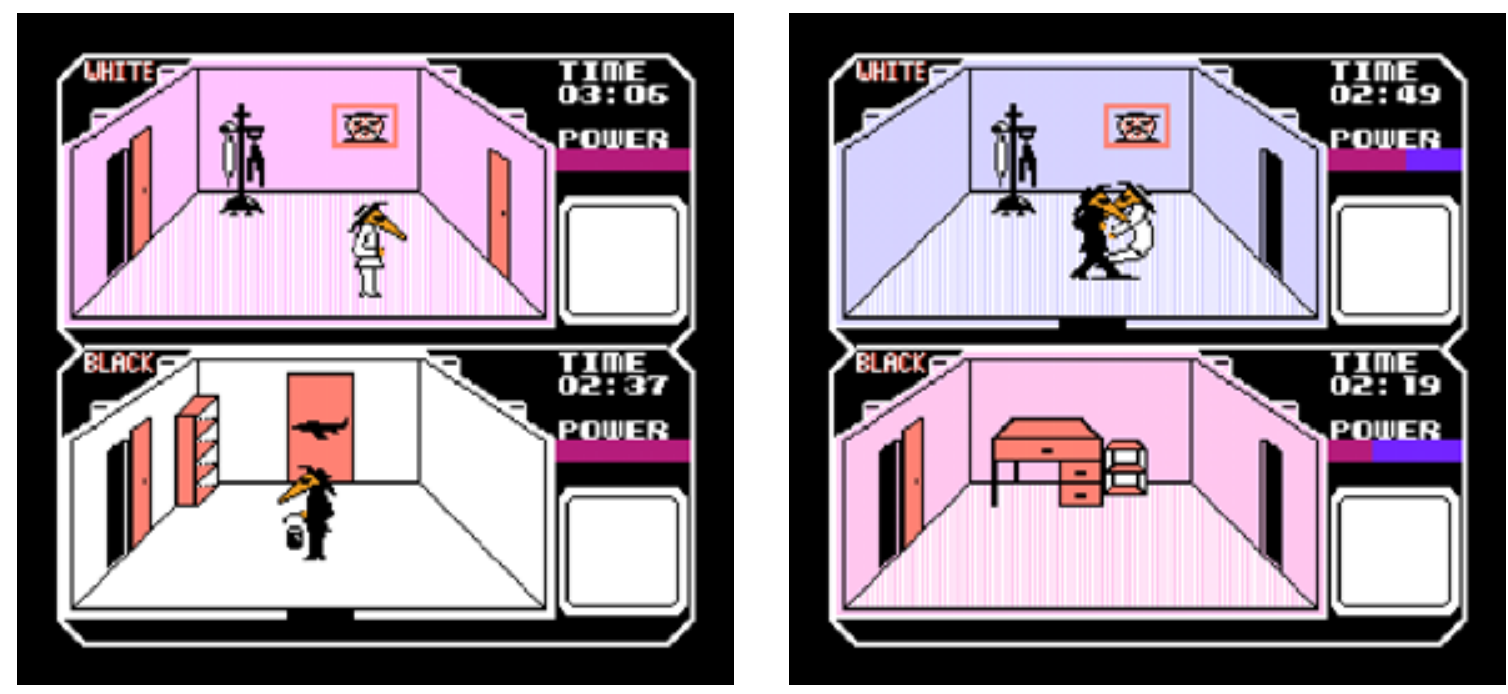

Ilustração 28. Telas de Spy vs Spy, versão para NES, rodando sob emulação

Visualmente, o jogo divide a tela em duas partes. Em cada uma, é exibido o cômodo onde o respectivo espião se encontra: na de cima, temos o cômodo com o espião branco e, na de baixo, o cômodo com o espião preto. Quando os dois espiões se encontram (veja a figura acima), eles são exibidos, juntos, em apenas uma das telas, e a outra fica vazia.

O fato do jogo permitir que os espiões preparem armadilhas um para o outro faz com que ver a ação do outro espião seja importante para a vitória. O bom jogador de Spy vs Spy será aquele que, além de agir rapidamente, também conseguir prestar atenção aos passos do adversário, a fim de evitar as armadilhas preparadas por ele.

Finalmente, apresentamos duas razões para considerar Spy vs Spy pertinente à nossa pesquisa. A primeira delas é o fato de termos uma duplicação das informações locais que são dadas ao jogador, que precisa organizá-las para formar, mentalmente, o mapa do jogo. Consideramos que este é um procedimento que poderá ser desenvolvido, futuramente, em nossos trabalhos artísticos, na medida em que temos um grau maior de complexidade criado pela existência de dois pontos de vista. A outra razão é o próprio espaço da embaixada, cujo número de cômodos aumenta conforme

51 Informações sobre o jogo obtidas em Spy vs. Spy (2006) e Mariner (2006). 
o jogador passa de nível, tornando-se cada vez mais labiríntico, o que é reforçado pela busca de objetos e perseguição/fuga em relação ao outro espião.

2.1.9 Espaços tridimensionais interativos

Como penúltimo tipo de espaço encontrado nos jogos eletrônicos, tais como analisados por Wolf, temos os jogos com representações tridimensionais do espaço. Wolf inicia a análise estabelecendo uma relação entre esses jogos e o desenvolvimento do uso de cenários e locações de filmagem ao longo da história do cinema. Assim como, no início do cinema, nós tínhamos espaços que eram representados através de "múltiplos ângulos e pontos de vista que são reunidos de tal forma que o espaço diegético parece ter uma configuração espacial consistente" (WOLF, 2002, p. 66) ${ }^{52}$, nós também vamos ter jogos onde o espaço tridimensional é representado a partir de um ou mais pontos de vista, sem que o jogador tenha liberdade total de movimento (esta liberdade de movimentação varia entre os diversos jogos citados por Wolf). Wolf apresenta como exemplo disso o já citado Spy vs Spy: nele, temos um espaço tridimensional representado na tela, por onde os personagens se movem. O cenário é fixo, e, além dos personagens, só alguns objetos podem ser movimentados. Mas, independente do movimento que os personagens fazem, eles sempre são representados do mesmo ângulo (isto é, não podemos ver mais de uma vista dos seus corpos).

Apesar das limitações técnicas desses jogos, para nós, eles já possuem um elemento que, para Lev Manovich, será uma das formas principais das novas mídias: o espaço navegável. Manovich desenvolve a idéia de espaço navegável a partir de dois jogos que, para ele, "exemplificam o potencial das novas mídias para dar origem a formas estéticas genuinamente originais e historicamente sem precedentes" (MANOVICH, 2001, p. 244): Doom e Myst.

\footnotetext{
Apesar de todas as diferenças em relação à cosmogonia, mecânica de jogo e modo de comercialização, os dois jogos possuem uma semelhança importante, a saber: ambos são jornadas espaciais. A navegação por um espaço tridimensional é um componente essencial, se não a chave, da mecânica do jogo. Doom e Myst apresentam ao jogador um espaço a ser atravessado, a ser mapeado através do deslocamento no seu interior. Ambos começam colocando o jogador em algum ponto deste espaço. Antes de chegar ao final do jogo, o participante precisa percorrê-lo quase que por inteiro, desvelando a sua geometria e a sua topologia, compreendendo a sua lógica e seus segredos. Em Doom e em Myst - e
}

52 Texto original em inglês: (...) multiple angles and viewpoints which are all linked together in such a way as to make the diegetic world appear to have at lease enough spatial consistency. 
em muitos jogos de computador - narrativa e tempo são sinônimos de deslocamento por um espaço tridimensional, avanços através de espaços fechados, níveis ou mundos. (MANOVICH, 2001, p. 245. Tradução nossa) ${ }^{53}$

À medida que as técnicas de computação gráfica e a tecnologia utilizada para executar os jogos (processadores, circuitos, e, na última década, placas gráficas) evoluíram, diversas formas de representação do espaço tridimensional passaram a ser utilizadas. Atualmente, a forma predominante de representação de espaços tridimensionais se dá pelo uso de sistemas gráficos que permitem ao jogador total liberdade de movimentação pelo cenário do jogo ${ }^{54}$, utilizando, como suporte, bibliotecas de código chamadas de 3D Engines. Um 3D Engine nada mais é do que uma peça de software que é utilizada por softwares que fazem uso de gráficos tridimensionais, como jogos e aplicações de visualização científica, e que se encarrega de realizar o desenho (processo chamado rendering) dos gráficos tridimensionais.

\subsubsection{Battlezone}

Diversos autores, como Steve Kent (2001, p. 148), DeMaria e Wilson(2003, p. 59) e Wolf (2002, p. 64) apontam o jogo Battlez̧one como sendo o primeiro jogo eletrônico a utilizar gráficos tridimensionais calculados em tempo real. Ele foi lançado pela Atari em 1980 (DE MARIA e WILSON, 2003, p. 59), e apresenta uma batalha de tanques cujo objetivo é destruir os tanques adversários e evitar ser atingido pelo inimigo. É importante observar que o jogo faz uso de linhas que indicam o periscópio do tanque do jogador (KENT, 2001, p. 148); temos, assim, um gráfico que indica não só a presença do jogador, mas também a principal possibilidade de ação do jogador no jogo: atirar.

53 Texto original em inglês: Despite all these differences in cosmogony, gameplay, and underlying economic models, the two games are similar in one key aspect. Both are spatial journeys. Navigation through 3-D spaces is an essential, if not the key, component of the gameplay. Doom and Myst present the user with a space to be traversed, to be mapped out by moving through it. Both begin by dropping the player somewhere in this space. Before reaching the end of the game narrative, the player must visit most of it, uncovering its geometry and topology, learning its logic and its secrets. In Doom and Myst - and in a great many other computer games - narrative and time itself are equated with movement through 3-D space, progression through rooms, levels, or words.

54 Isto é, ele pode mover-se para cima, para baixo, para a esquerda, para direita, para frente e para trás. 

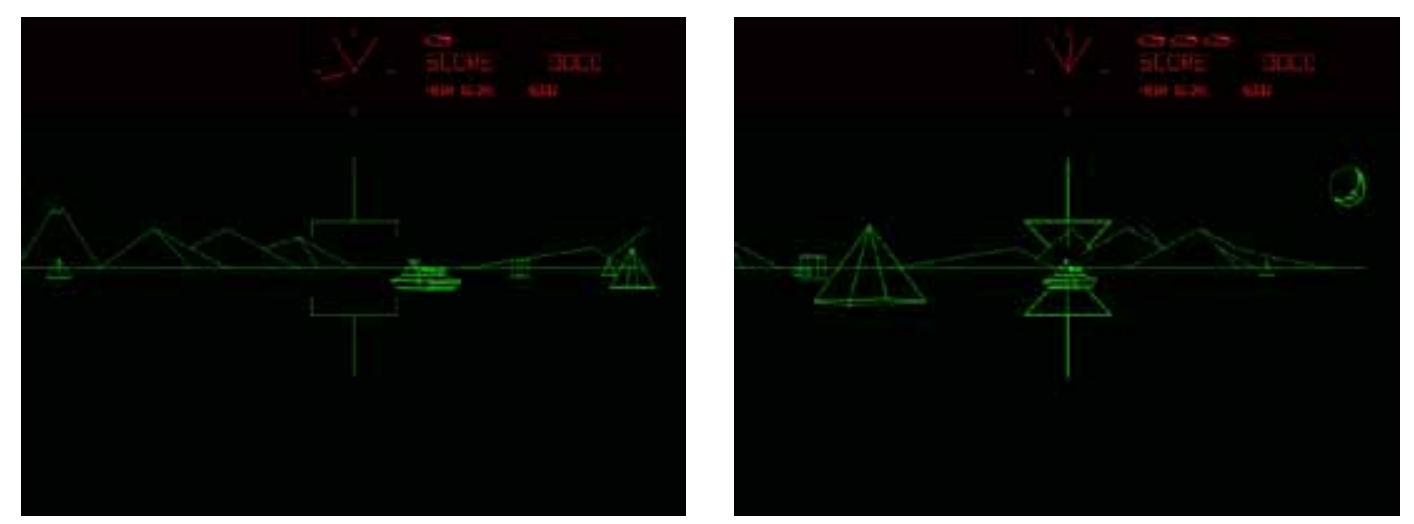

Ilustração 29. Duas imagens de Battlezone, onde a mira do tanque indica a presença do jogador no cenário. A seguir, o dano ao tanque do jogador é representado pelas rachaduras no vidro do periscópio. Imagens obtidas através da emulação do jogo original num computador atual.

Outros jogos deram continuidade ao uso de gráficos tridimensionais calculados em tempo real. Os objetos passaram a ter os seus polígonos preenchidos, e não mais representados apenas com linhas. Algoritmos foram criados para calcular a variação da cor do objeto, de acordo com o ângulo do mesmo em relação às fontes de luz do cenário; aos poucos, os $3 d$ engines foram se tornando cada vez mais sofisticados, sempre em busca do maior grau de realismo possível ${ }^{55}$, e, em sua grande maioria, utilizando as regras da perspectiva renascentista para criar este realismo ${ }^{56}$.

\subsubsection{Doom}

Depois de Battlez̧one, outro marco no desenvolvimento da representação do espaço tridimensional nos jogos eletrônicos, tal como colocado por diversos autores - Manovich (2001, p. 244), De Maria e Wilson (2003, p. 274), Kent (2001, p. 459) - é o lançamento do jogo Doom pela id Software em 1992. Doom tornou-se o principal representante do gênero conhecido por first person shooters (KENT, 2001, p. 459), em que o jogador deve atirar em praticamente tudo que se move e coletar munição e curativos ao longo do caminho.

Doom também é pertinente à nossa pesquisa, porque ele, assim como seu antecessor $W o l-$ fenstein 3D e boa parte dos jogos do tipo first person shooters, utiliza cenários que são constituídos por salas interligadas por inúmeros corredores. De acordo com Jesus de Paula Assis (1999, pp. 101-2),

55 Para uma história da evolução dos 3 d engines até o final dos anos 90, ver Shahrani (2007)

56 Aqui, é importante fazer referência à observação de Manovich (2001, p. 257) sobre a ocorrência do espaço "nãohomogêneo" nos ambientes tridimensionais. Para ele, apesar da tecnologia empregar as regras da perspectiva renascentista, os espaços ainda estão longe de apresentar a homogeneidade obtida na pintura renascentista; ainda teríamos, segundo Manovich, os espaços "fragmentados”, tal como Erwin Panofsky definiu o espaço na arte grega: "o espaço não era percebido como algo susceptível de englobar e dissipar o contraste entre corpos e não-corpos, mas apenas como aquilo que subsiste, se quisermos, entre os corpos. $\mathrm{O}$ espaço foi, assim, mostrado artisticamente, em parte pela mera sobreposição, em parte por uma justaposição ainda não sistemática” (PANOFSKY, 1999, p. 42). 
esta configuração espacial apresenta a vantagem de limitar as possibilidades de deslocamento do usuário, obrigando-o a seguir uma determinada seqüência de movimentos, o que facilitaria a programação do jogo e a sua roteirização, além de tornar o jogo compatível com o poder de processamento das máquinas da época. Assis descreve a configuração espacial desses jogos como sendo um labirinto, sendo que neles podemos encontrar as seguintes características do labirinto:

a) o jogador desloca-se sem ter uma visão global do espaço em que se encontra (em alguns jogos, mapas são itens preciosos, que podem ser obtidos pelo jogador ao longo da partida, mas, geralmente, não de modo fácil);

b) o jogador tem objetivos a cumprir na sua caminhada (temos aqui uma proximidade com o centro do labirinto, que deve ser alcançado por aquele que se aventura em seus corredores).

c) e, talvez a semelhança mais óbvia, a planta dos cenários (mesmo que ela possa ser apenas inferida, como no caso dos jogos em que nunca se tem acesso a algum tipo de mapa) possui, em quase todos os jogos do gênero, semelhanças com a planta dos labirintos tradicionais.
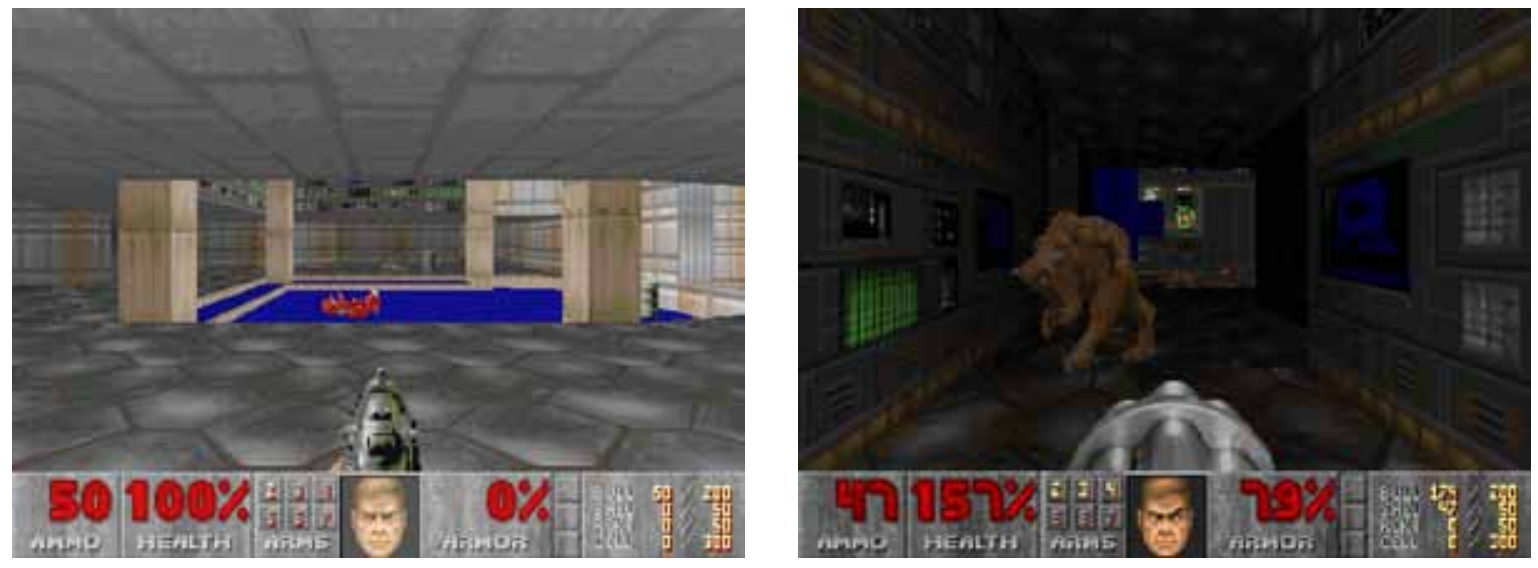

Ilustração 30. Imagens de Doom

\subsubsection{Myst}

Assim como Doom, Myst ${ }^{7}$ é apontado por Manovich (2001, p. 244) como um dos jogos que marcam o uso do espaço navegável pelas novas mídias. Myst também é um marco na história dos jogos por diversos motivos: a) apresentou cenários com um grau de qualidade e elaboração inéditos para a época; b) ao contrário da grande maioria dos jogos eletrônicos, o jogador não morre; c) o

57 Lançado pela Cyan em 1993 (DEMARIA, WILSON, p. 258). 
que torna o jogo difícil é a falta de pistas sobre o que se deve fazer; o jogador inicia sua jornada num cenário vazio, com traços de presença humana, mas sem encontrar outros personagens. Tem-se um quebra-cabeça cujas peças estão espalhadas por diversos mundos interligados, chamados de idades. Para que se possa avançar no jogo, é preciso resolver uma série de enigmas, a partir de indícios que estão espalhados pelo cenário.
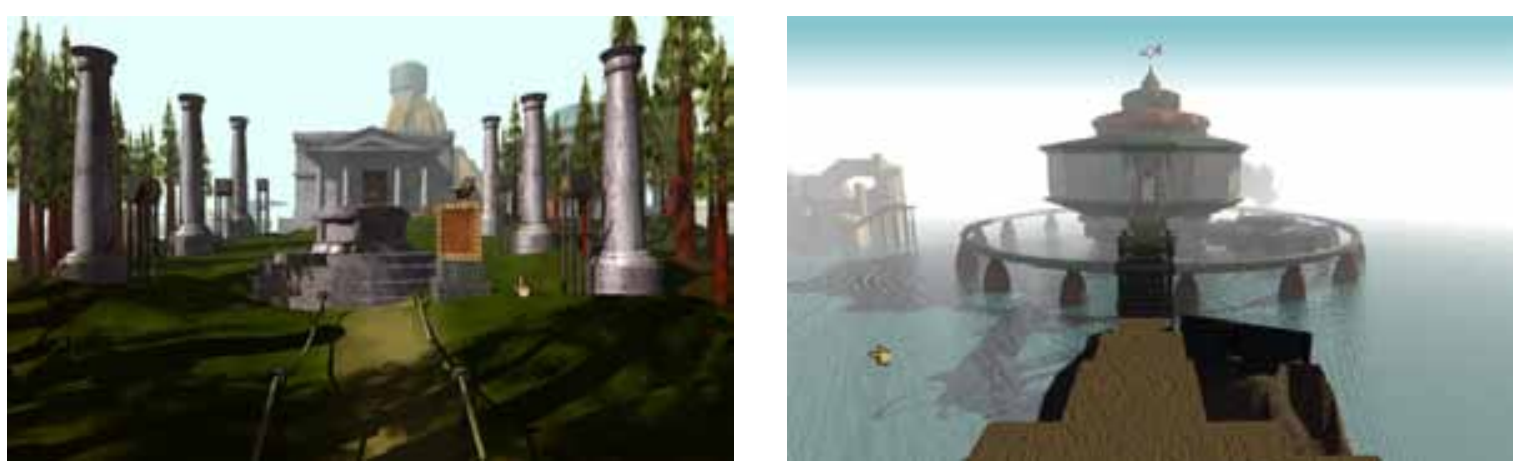

Ilustração 31. Dois cenários de Myst

Se em Doom temos uma série quase infinita de corredores e espaços fechados, que remetem ao labirinto, em Myst são os enigmas que aproximam a experiência do jogo da experiência do labirinto, pois são eles que impedem o jogador de avançar. Em seus cenários, o jogador sempre conserva a sua liberdade de movimentação, mas não consegue passar para os outros mundos sem resolver os diversos enigmas que lhe são colocados. Isto é, em muitos momentos, as possibilidades de ação e de movimento são numerosas, mas não se sabe para onde ir ou o que fazer.
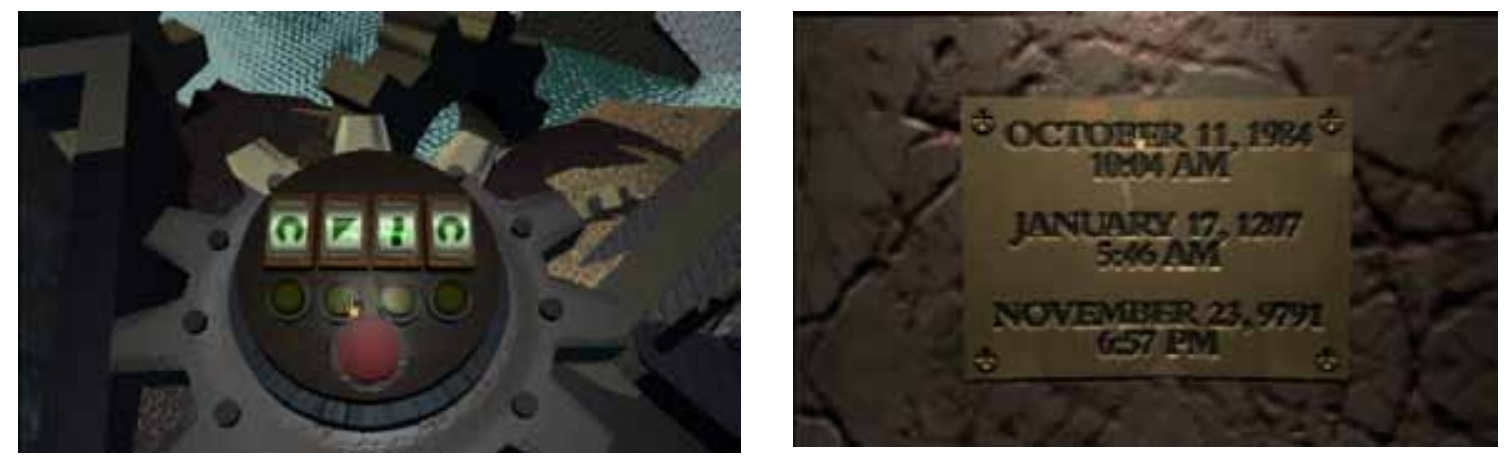

Ilustração 32. Enigmas de Myst. à esquerda, temos uma série de botões, cuja configuração exata precisa ser encontrada ao longo do cenário. Já à direita, temos as datas que precisarão ser utilizadas no planetário do cenário principal do jogo, para termos acesso a uma das idades de Myst.

Podemos, então, identificar na experiência do jogador de Myst diversas das características associadas por Calabrese ao labirinto: a "complexidade, cuja ordem existe, mas é complicada ou 
oculta” (CALABRESE, 1987, p. 145), “o prazer da obnubilação perante a sua inextricabilidade (acompanhado do medo eventual) e o gosto de a vencer com as astúcias da razão" (idem), e "a reconstrução (que) procede de resto por inferências locais" (ibidem, p. 147).

\subsubsection{Espaços Mapeados}

Como espaços mapeados, Wolf aponta os mapas que diversos jogos apresentam para que o jogador possa se orientar em um espaço que é muito mais vasto que a fração exibida na tela (entre os jogos já analisados aqui, podemos citar Defender). Alguns jogos, entretanto, vão utilizar mapas como o seu espaço principal (SimCity, Civilization). São jogos em que o jogador assume um ponto de vista chamado de "Deus", que pode atuar em diversos (ou em todos os) pontos do cenário, olhando-o de cima, sem precisar deslocar um personagem de um ponto a outro (basta rolar a tela).
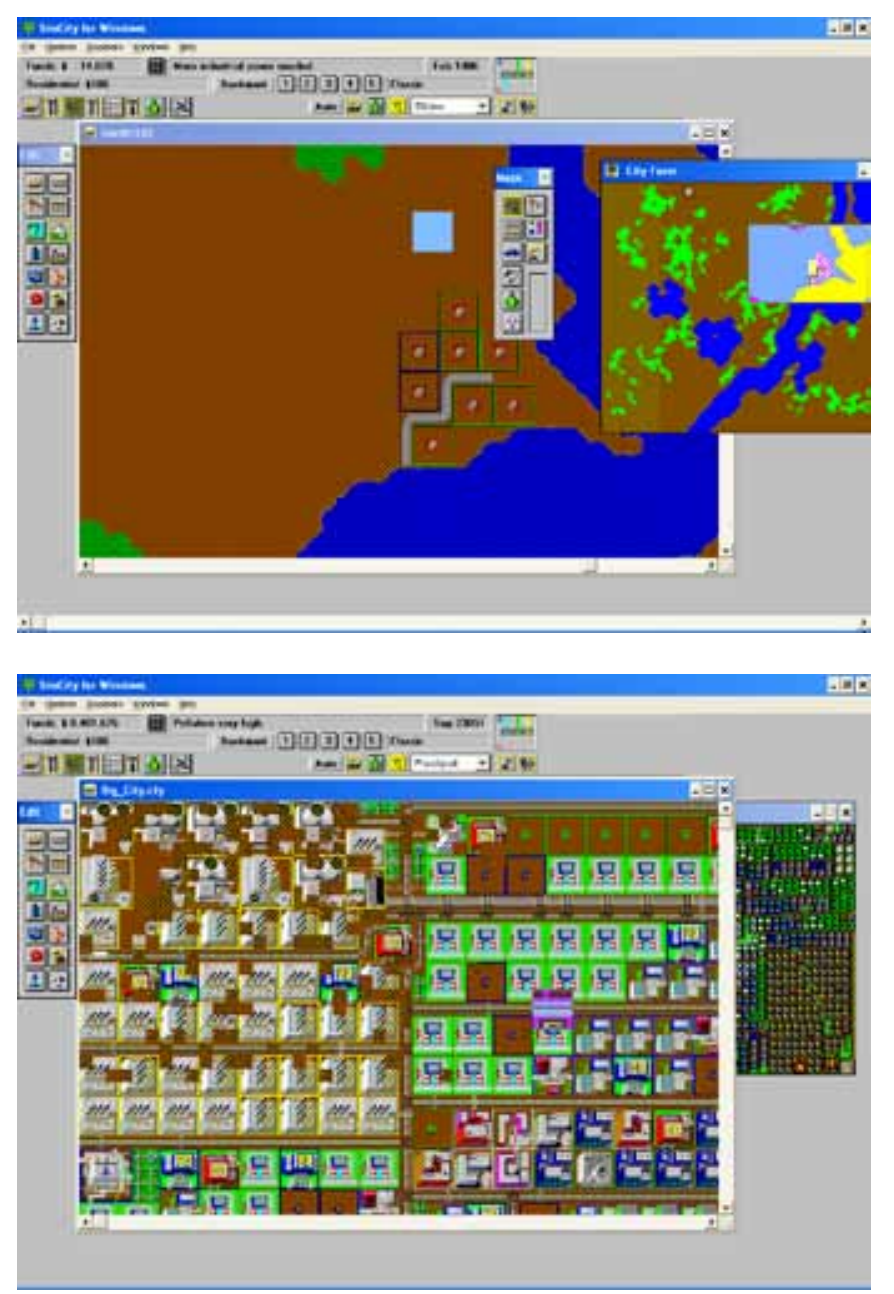

Ilustração 33. Duas imagens de SimCity 2000. Acima, uma cidade no seu início, basicamente vazia; abaixo, uma cidade superpovoada. Imagens capturadas diretamente do jogo. 
Em relação à presença do labirinto, temos uma situação próxima aos jogos com espaço restrito às dimensões da tela: temos labirintos apenas em jogos nos quais o desenho do território do jogo, do mapa, se aproxima do desenho de um labirinto. Nesse sentido, podemos citar novamente SimCity, o conhecido simulador de cidades lançado pela Maxis em 1989, pois ele remete à associação entre a cidade e o labirinto, que podemos encontrar em Cristina Grau (1997, p. 125) e Borges (2008b, p. 118 ).

2.1.11 Jogos que utilizam o espaço urbano

Adicionamos esta categoria à lista de espaços criada por Wolf para agrupar alguns jogos desenvolvidos comercialmente - BotFighters, citado por (HALL, 2005) ${ }^{58}$ - e experimentos realizados em universidades - PacManhattan ${ }^{59}$ e Human PacMan ${ }^{60}$ - que possuem em comum o uso do espaço urbano como sendo o espaço do jogo, através da utilização de dispositivos de computação móvel, celulares e localizadores GPS. Com estes dispositivos, o espaço real é "mapeado", constituindo o território do jogo, e o deslocamento dos jogadores pela cidade afeta a localização dos mesmos dentro do espaço do jogo, assim como as possibilidades de ação de cada jogador.

Em PacManhattan, por exemplo, a ilha de Manhattan é utilizada como o labirinto do jogo PacMan:

Um jogador vestido de Pac-man correrá pela praça Washington de Manhattan enquanto tenta coletar toda a "comida" virtual que está espalhada ao longo das ruas. Quatro jogadores vestidos como os fantasmas Inky, Blinky, Pinky e Clyde tentarão capturar o Pacman antes que toda a comida seja coletada.

Com o uso de celulares, conexões Wi-Fi e software desenvolvido pela equipe de PacManhattan, Pac-Man e os fantasmas serão rastreados a partir de uma central, e os seus movimentos serão transmitidos pela Internet para espectadores de todo o mundo.

(PACMANHATTAN, 2007. Tradução nossa) ${ }^{61}$

58 HALL, Justin. Future of Games: Mobile Gaming. In: RAESSENS, Joost, GOLDSTEIN, Jeffrey. Handbook of Computer Game Studies. Cambridge, Massachussets; London : The MIT Press, 2005.

59 Projeto sendo desenvolvido na New York University, http://www.pacmanhattan.com/.

60 Projeto sendo desenvolvido na National University of Singapore, http://www.mixedreality.nus.edu.sg/index. php?option $=$ com content\&task $=$ view\&id $=42 \&$ Itemid $=74$.

61 Texto original em inglês: A player dressed as Pac-man will run around the Washington square park area of Manhattan while attempting to collect all of the virtual "dots" that run the length of the streets. Four players dressed as the ghosts Inky, Blinky, Pinky and Clyde will attempt to catch Pac-man before all of the dots are collected.

Using cell-phone contact, Wi-Fi internet connections, and custom software designed by the Pac-Manhattan team, Pac-man and the ghosts will be tracked from a central location and their progress will be broadcast over the internet for viewers from around the world. 
Estes jogos e experiências são pertinentes à nossa pesquisa por relacionarem o espaço do jogo com o espaço da cidade, que, como já colocamos, é relacionado com o labirinto por diversos autores (é importante observar que a principal referência para os projetos analisados aqui também é o jogo mais fortemente associado ao labirinto, PacMan). Além disso, eles também constituem os primeiros jogos eletrônicos a utilizarem o espaço aumentado, como se refere Manovich no artigo The Poetics of Augmented Space: Learning from Prada (MANOVICH, 2005). Ao contrário do espaço virtual, em que temos a construção de um espaço paralelo ao espaço real (poderíamos citar como exemplo mais atual a comunidade virtual Second Life $e^{62}$, o espaço aumentado é constituído pelo “acréscimo de camadas de informação sobre o espaço físico", através do uso crescente de dispositivos de computação móvel e de telefones celulares com capacidade de processamento cada vez maior, que conectam os espaços reais às redes de informação, fazendo com que estar conectado à Internet não implique, necessariamente, em estar sentado em frente a um computador de mesa, como era necessário há alguns anos atrás.

\subsubsection{A Internet como espaço do jogo}

Finalmente, para encerrar a lista de tipos de espaço dos jogos eletrônicos e de jogos onde o labirinto está presente, gostaríamos de mencionar o jogo Evidence (2006), produzido pela Dreamcatcher Interactive ${ }^{63}$. Em Evidence, a missão do jogador é seguir os passos do serial killer Phoenix, resolvendo uma série de enigmas e quebra-cabeças. Para resolvê-los (e é aqui que este jogo é pertinente à nossa pesquisa), o jogador precisa buscar uma série de informações na Internet, saindo do jogo e abrindo o seu navegador (TODD, 2007). Assim, o espaço do jogo torna-se, em diversos momentos, o espaço da Internet, cujos aspectos labirínticos já foram apontados por inúmeros autores, entre eles, Leão (2005, p. 22) e Machado (1997b).

$\begin{array}{ll}62 & \text { http://www.secondlife.com/ } \\ 63 \text { http://www.dreamcatchergames.com }\end{array}$ 




\section{B Cubos de Cor}

O trabalho Cubos de Cor ${ }^{64}$ foi criado a partir de quatro referências principais: os jogos de computador baseados em texto, o filme Cubo (1997), o estudo de Cristina Grau (1997) sobre os espaços encontrados nos textos de Borges e a série Homenagem ao Quadrado, de Josef Albers. Vamos revisar, de forma breve, cada uma dessas referências, com exceção dos jogos baseados em texto, cujos aspectos labirínticos foram discutidos no segundo capítulo desta dissertação.

\section{B.1 Os espaços labirínticos de Borges}

No prefácio de Borges Y La Arquitectura, Grau esclarece que o livro consiste em uma abordagem realizada a partir do campo da Arquitetura, cujo tema é o "espaço arquitetônico que marca grande parte de sua obra; os espaços nos quais Borges se inspira e os espaços sugeridos pela leitura de seus textos”"65 (GRAU, 1997, p. 11, tradução nossa). Após analisar a presença da cidade e do espaço urbano nos primeiros poemas de Borges, Grau elege os espaços labirínticos como sendo os espaços característicos de Borges, observando que a presença do labirinto dificilmente é explícita e que a referência ao mesmo

\footnotetext{
Em alguns casos é uma imagem que faz parte do conteúdo da narrativa, em outros, a estrutura da narrativa é labiríntica; enredos que contém outros enredos, histórias que se entrelaçam, que voltam a si mesmas de forma recorrente, a fragmentação do texto e o ritmo insistente sugerem a imagem do labirinto.

Em outros momentos, o labirinto é um símbolo que encontramos a cada passo; Borges nos oferece, obsessivamente - através do símbolo do labirinto - a imagem caótica do universo e do indivíduo, indefeso, perdido nele. Em outros casos o labirinto é traçado sem ser nomeado, deixa de constituir-se em imagem espacial para integrar o texto, é uma estrutura que organiza toda a matéria literária e que só se descobre à medida em que se avança na leitura ou na releitura.

(GRAU, 1997, p. 61-2, tradução nossa) ${ }^{66}$
}

Grau define e analisa quatro tipos, quatro maneiras pelas quais o labirinto se manifesta e é construído nos textos de Borges. A primeira forma é o "labirinto criado por adições infinitas", 64 http://www.andreithomaz.com/arte/color cubes

65 Texto original em espanhol: (...) espacio arquitectónico que enmarca una gran parte de su obra; el que sirvió de sugerencia a Borges y el que nos sugiere la lectura.

66 Texto original em espanhol: En unos casos es uma figura que forma parte del conenido de la narración, en otros, la estructura del relato es laberíntica; argumentos que contienen otros argumentos, historias que se entrelazan, que se repliegan sobre sí mismas en donde el orden recurrente, la fragmentación de texto y el insistente ritmo sugieren la imagem del laberinto.

Otras veces el laberinto es un símbolo que encontramos a cada paso; obsesivamente, Borges nos ofrece - a través del símbolo del laberinto - la imagen caótica del universo y del individuo indefenso perdido en él. En otros casos el laberinto se dibuja sin ser nombrado, deja de constituirse en imagem espacial para integrar el texto, es uma estructura que organiza toda la materia literaria y que sólo se va descubriendo a medida que avanza en la lectura o en la relectura. 
construído "a partir de uma figura simples” e pela "justaposição de tal figura nas diferentes dimensões do espaço euclidiano". Este é o labirinto de um dos contos mais conhecidos de Borges, $A$ Biblioteca de Babel, onde o hexágono é a figura que se repete, em número "indefinido, e talvez infinito”. A repetição de uma unidade espacial constituirá um espaço labiríntico, de acordo com a análise realizada por Grau, principalmente porque a uniformidade espacial impede a orientação (GRAU, 1997, p. 66), já que quem percorre tal espaço não consegue estabelecer referências espaciais.

Também é importante citar a relação entre o labirinto e o fato da Biblioteca de Babel ser um espaço infinito, colocada por Grau, pois esta figura do infinito estará presente em Cubos de Cor:

É portanto a infinidade da Biblioteca que serve para caracterizá-la como um labirinto, como um espaço destinado ao equívoco e à desorientação. Numa estrutura complexa, mas finita, é possível descobrir as suas leis de composição. Na Biblioteca, o que causa espanto é que a justaposição de prismas hexagonais e quadrados se estenda infinitamente, no sentido do comprimento de da profundidade, para cima e para baixo, preenchendo todo o espaço. Isto porque o conceito de infinito é estranho ao homem, vai além do que os sentidos podem perceber, não é mais que um artifício que tem sentido apenas no raciocínio abstrato ou no cálculo matemático.

(GRAU, 1997, p. 75, tradução e grifo nossos) $)^{67}$

O segundo e quarto tipos de manifestação do labirinto definidos por Grau não são pertinentes a Cubos de Cor, e por isso serão apenas citados aqui: os labirintos das duplicações e simetrias (obtidas principalmente com o uso de espelhos, em que não se sabe mais o que é real e o que é reflexo) e a cidade como labirinto. Mas a terceira forma de manifestação do labirinto identificada por Grau nos interessa por trazer novamente a idéia de infinito e por ter sido uma de nossas referências para a realização de Cubos de Cor: são os labirintos com um único percurso mas que não possuem fim.

\footnotetext{
Este tipo de labirinto é criado, em sua materialidade espacial, por adições sucessivas ao longo de uma única linha original, seja reta, em ziguezague, curva ou helicoidal. Seguindo este esquema, Borges, através da escrita - na descrição dos edifícios ou do percurso de seus heróis pela arquitetura de ficção - cria dois tipos de labirintos infinitos, um pela contínua adição de unidades arquitetônicas ao espaço, outra, pela sucessiva e constante subdivisão do espaço em unidades cada vez menores.

(GRAU, 1997, p. 107, tradução nossa) ${ }^{68}$
}

67 Texto original em espanhol: Es pues la infinitud de la Biblioteca la que sirve para caracterizarla como laberinto, como espacio destinado al engaño y a la desorientación. En uma estructura compleja, pero finita, podemos acabar descubriendo sus leyes de composición. En la Biblioteca, lo que causa espanto es que la yuxtaposición de prismas hexagonales y cuadrados se extienda infinitamente, a lo largo y a lo ancho, hacia arriba y hacia abajo, rellenando todo el espacio. La razón es que el concepto de infinito es extraño al hombre, va más allá de lo que los sentidos pueden percibir, no es más que un recurso que sólo tiene sentido en el razonamiento abstracto o en el cálculo matemático.

68 Texto original em espanho: Este tipo de laberinto se genera en su materialidad espacial por adiciones sucesivas a lo largo de una sola generatriz recta, zigzagueante, curvada o helicoidal. Siguiendo este esquema, Borges, a través de la escritura - en la descripción de los edificios o del recorrido de sus héroes por la arquitectura de la ficción - crea dos tipos de laberintos infinitos, uno, por la continua adición de piezas arquitectónicas en el espacio, otro, por la sucesiva y constante subdivisión del especaio en piezas cada vez menores. 
Nos labirintos de contínua adição de elementos, "a arquitetura, que inicialmente apresenta um caminho, acaba por se transformar num cárcere do qual não se pode sair": por mais que se caminhe, não se chega ao final do caminho, a cada instante este parece ser mais comprido do que no instante anterior; Grau faz um paralelo com uma escada em espiral, que causa "a impressão de que os degraus nascem embaixo de nossos pés à medida que subimos” (GRAU, 1997, p. 111).

Já os labirintos gerados por subdivisão infinita seguem o modelo do paradoxo de Zenão, "Aquiles e a tartaruga", citado de forma mais direta por Borges no conto A morte e a bússola (GRAU, 1997, p. 115):

- No seu labirinto sobram três linhas - disse por fim. - Eu sei de um labirinto grego que é uma linha única, reta. Nessa linha tantos filósofos se perderam que bem pode nela se perder um mero detetive. Scharlach, quando noutro avatar o senhor me caçar, finja (ou cometa) um crime em $\mathrm{A}$, logo um segundo crime em $\mathrm{B}$, a oito quilômetros de $A$, em seguida um crime em $C$, a quatro quilômetros de $A$ e de $B$, na metade do caminho entre os dois. Aguarde-me depois em D, a dois quilômetros de A e de C, de novo na metade do caminho. Mate-me em D, como agora vai me matar em Triste-le-Roy.

- Para a outra vez que o matar - replicou Scharlach - prometo-lhe esse labirinto, que consta de uma única linha reta e que é invisível, incessante.

(BORGES, 2008a, p. 135)

Neste tipo de labirinto, Grau inclui os casos de recursão infinita que podemos encontrar em diversos textos de Borges, como o sonho dentro do sonho, de A Escrita do Deus, publicado em $O$ Aleph, e o homem que escreve um poema sobre outro homem (GRAU, 1994, pp. 116-7):

En un desierto lugar del Irán hay una no muy alta torre de piedra, sin puerta ni ventana. En la única habitación (cuyo piso es de tierra y tiene forma de círculo) hay una mesa de madera y un banco. En esa celda circular, un hombre que se parece a mí escribe, en caracteres que no comprendo, un largo poema sobre un hombre que en otra celca circular escribe un poema sobre un hombre que en otra celda circular... El proceso no tiene fin y nadie podrá leer lo que los prisioneros escriben.

(BORGES apud GRAU, 1994, p. 117)

\section{B.2 O filme Cubo}

O filme Cubo, dirigido por Vincenzo Natali e lançado em 1997, apresenta seis personagens que "acordam" presos dentro de uma estrutura formada por cubos, conectados entre si. Eles não sabem porque foram colocados ali, e começam a se deslocar pelos cubos, à procura de uma saída. O filme acompanha as discussões e conflitos que surgem no grupo, bem como as estratégias que seus integrantes criam, à medida que eles se movimentam. 


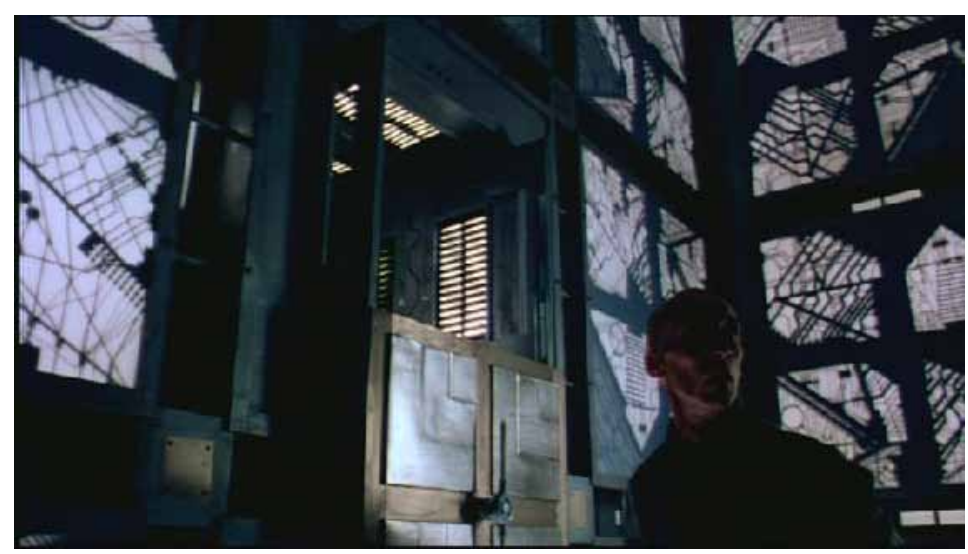

Ilustração 34. Uma das cenas iniciais de Cubo.

Nossa primeira observação sobre as características labirínticas do espaço de Cubo é a de que temos um caso de "labirinto criado por adições infinitas", tal como a Biblioteca de Babel. No caso de Cubo, nós temos cubos sendo distribuídos, de maneira uniforme, nas três direções do espaço, mas em número finito; após a passagem por vários cubos, um dos personagens declara que trabalhou no desenvolvimento do projeto da estrutura. Assim, eles ficam sabendo que estão dentro de um grande cubo, e podem inclusive deduzir as suas dimensões (o grande cubo teria 14 cubos de aresta, nos seus cálculos).

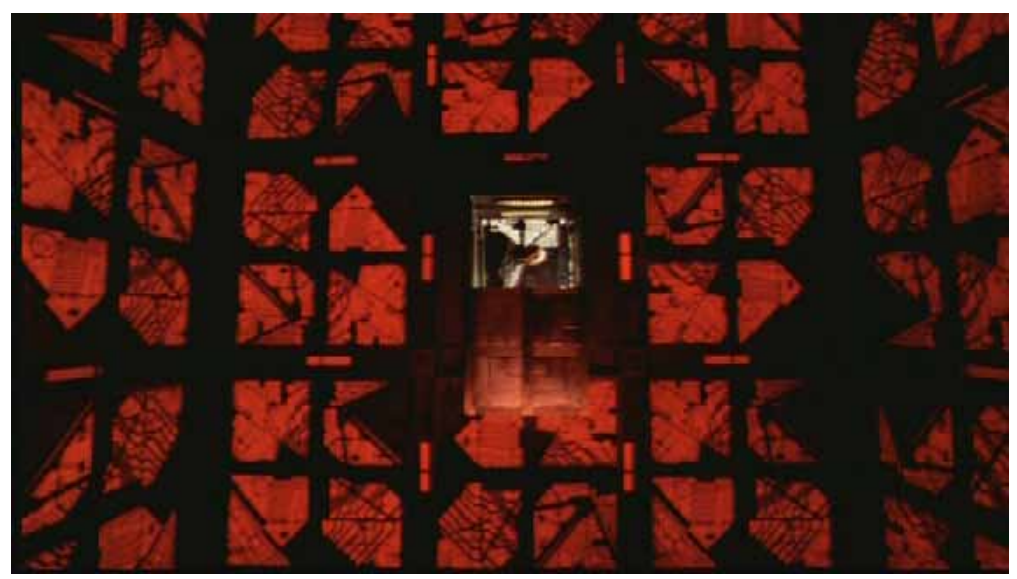

Ilustração 35. Outra cena de Cubo, onde podemos ver um dos personagens abrindo a passagem de um cubo para outro.

Duas características dos cubos permitem aos personagens estabelecer alguma forma de referência (ao contrário dos hexágonos que formam a Biblioteca de Babel): eles possuem cores diferentes, e alguns contém armadilhas, outros não. Mas é o corpo de um dos integrantes do grupo que funciona como a principal referência associada a um cubo, pois é ele que vai permitir aos membros remanescentes perceberem que retornaram a um cubo previamente visitado. 
Se as armadilhas podem funcionar como um marco, como referência espacial, elas também tornam o percurso pela estrutura de cubos mais complicado, pois não é possível simplesmente andar em linha reta. As armadilhas desempenham, assim, o mesmo papel das paredes num labirinto tradicional: são obstáculos que devem ser contornados.

Outro aspecto importante para explicar as características labirínticas de Cubo pode ser encontrado no texto Nó e Labirinto, de Calabrese, quando ele define o labirinto como "uma das muitas figuras do caos, entendido como complexidade, cuja ordem existe, mas é complicada e oculta" (CALABRESE, 1987, p. 145). A existência ou não de uma ordem (e de uma razão) que justifique a sua presença naquele espaço é uma das causas de conflito e angústia entre os personagens do filme. Esta tentativa de decifrar a ordem e a lógica do espaço também pode ser percebida nas três leituras diferentes dos números que estão presentes nas passagens entre os cubos, realizadas ao longo do filme:

\begin{abstract}
Leaven, a estudante de matemática, percebe que para atravessar a máquina o grupo precisa decifrar o código do Cubo, os números impressos no marco da entrada de cada cubo. No início, Leaven acredita que os cubos com armadilhas podem ser identificados através da presença de números primos no seu código, mas depois ela percebe que o código também se refere a referências num mapa tridimensional, coordenadas cartesianas, antes de finalmente chegar à conclusão de que o código se refere ao movimento do Cubo.

(FEATHERSTONE, 2007, tradução nossa) ${ }^{69}$
\end{abstract}

A descoberta de que os cubos movem-se dentro da estrutura é particularmente crucial para os personagens do filme, pois eles percebem que o tempo disponível para chegar à saída é pequeno e que, caso não consigam escapar, terão que esperar que a estrutura complete mais um ciclo de movimentos para terem a oportunidade de sair do cubo. Ela ocorre a partir do reencontro com o corpo do primeiro personagem morto durante a sua jornada: se eles não deram meia-volta, e se voltaram a um cubo já visitado, é porque os cubos se movem. É neste momento que Leaven finalmente decifra o real significado dos números impressos nas entradas de cada cubo.

\title{
B.3 A série Homenagem ao Quadrado, de Josef Albers
}

Além de artista visual, Josef Albers também teve uma importante atuação como professor, sendo um dos principais membros do corpo docente da Bauhaus. Seu trabalho mais conhecido é a

69 Texto original em inglês: Leaven, the Maths student, realises that in order to transgress the machine the group must crack the Cube's code, the numbers printed on the frame of each room's entrance. Initially, Leaven believes that trapped rooms can be identified by prime numbers contained within the code, later she realises that the code also refers to three-dimensional map references, Cartesian co-ordinates, before finally reaching the conclusion that the code relates to the motion of the Cube. 
série Homenagem ao Quadrado, onde fica explícito o interesse do artista por aspectos fisiológicos da visão, que afetam a nossa percepção das cores e criam a sensação de profundidade ${ }^{70}$, sem que seja preciso fazer uso da perspectiva e de outros códigos de representação.

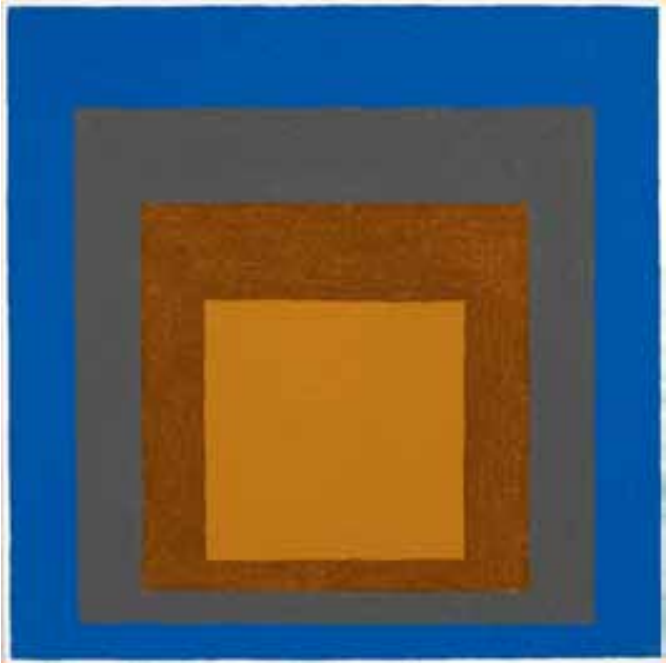

Ilustração 36. Josef Albers. Homenagem ao Quadrado, 1961.

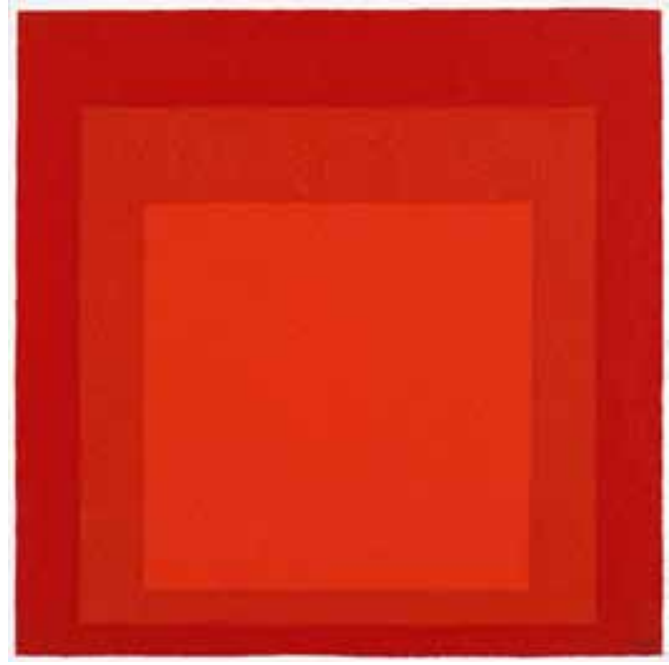

Ilustração 37. Josef Albers. Homenagem ao Quadrado, 1968. Fonte das imagens: site da The Josef e AnniAlbers Foundation, http://www.albersfoundation.org- Acesso em 10/05/2008.

Este trabalho de Albers, e a referência à algumas das características da pintura moderna, nos interessa porque em Cubos de Cor propomos um jogo com a representação visual. Explicaremos este aspecto, com mais detalhes, na página 88, ao descrevermos a animação que encerra o trabalho.

\section{B.4 Cubos de Cor}

Cubos de Cor apresenta-se como sendo um jogo baseado em texto; inicialmente, o visitante recebe instruções de como se movimentar, utilizando comandos como para frente, direita, esquerda, etc., que ele precisa digitar no campo localizado no centro do trabalho. 


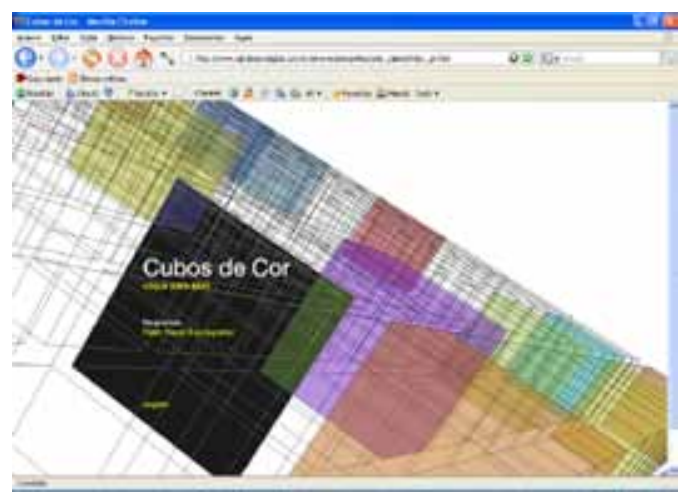

Ilustração 38. Capa do trabalho.

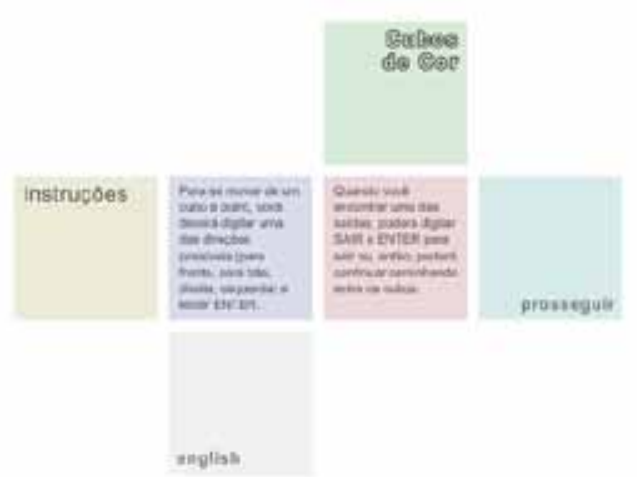

Ilustração 39. Tela com as instruções.

Logo na entrada, o espaço onde o jogador se encontra é descrito como sendo "um cubo completamente branco". E a cada movimento do espectador, o espaço onde ele se encontra sempre será descrito como um cubo. Entretanto, as descrições dos cubo atual seguintes sempre é relativa ao cubo anterior, especificando diferenças de cor. Nosso objetivo ao criar as descrições dos espaços em termos relativos, foi a de dificultar o estabelecimento de referências espaciais, já que não há textos similares a "você está diante de uma casa" ou "aqui há uma fonte d'água", como ocorre usualmente nos jogos baseados em texto.

E, também ao contrário do que ocorre nos primeiros jogos desse tipo, em que não é dado nenhum elemento visual a partir do texto, a cor do cenário é apresentada ao espectador, na tela do computador, como um plano de cor.

Ilustração 40. Descrição do cubo inicial. 


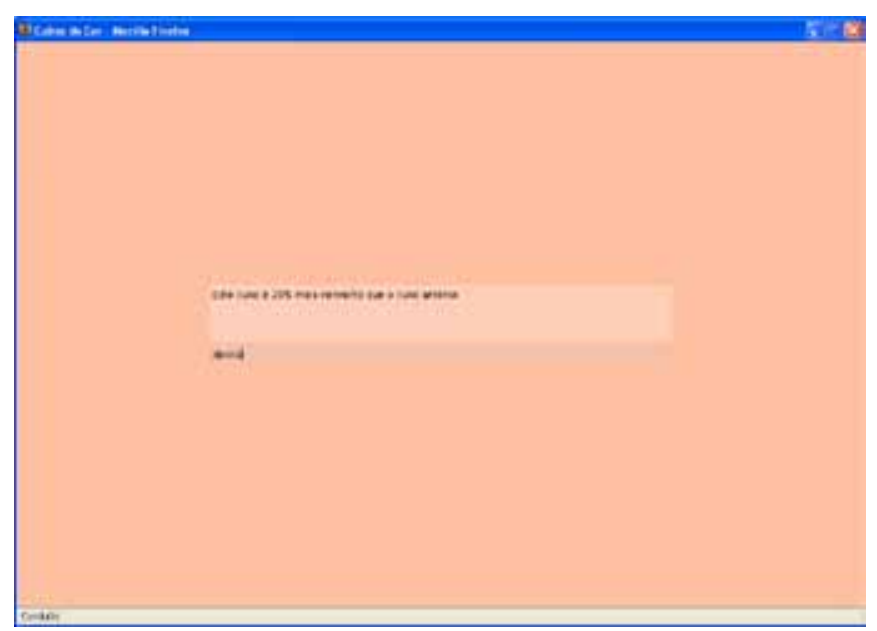

Ilustração 41. Imagem do trabalho após alguns movimentos do espectador.

É importante observar que não utilizamos nenhum recurso para representar, visualmente, a profundidade dos cenários ou o desenho dos cubos. A construção do espaço, que é realizada mentalmente por parte do espectador, se dá, no nosso ponto de vista, por três fatores principais:

1) ao acessar o endereço do trabalho, o espectador vê uma tela com o título Cubos de Cor e com a informação dos requisitos para poder ver o trabalho. Para esta tela, criamos uma ilustração que mostra alguns cubos coloridos, dentro de uma malha de cubos wireframe (isto é, que possuem apenas os contornos desenhados). Fizemos isto para criar uma sugestão visual do espaço que virá a seguir;

2) as descrições textuais, que descrevem sempre o espaço no qual o espectador se encontra como sendo o interior de um cubo;

3) o próprio título do trabalho.

Para poder escrever as descrições dos espaços, organizando-as de forma coerente com o espaço que queríamos sugerir, foi necessário criar uma grade de quadrados, com a descrição de cada cubo, para termos uma representação espacial, a partir da qual escrevemos as descrições utilizadas pelo trabalho. Entretanto, este 'mapa' não é disponibilizado ao espectador do trabalho. 


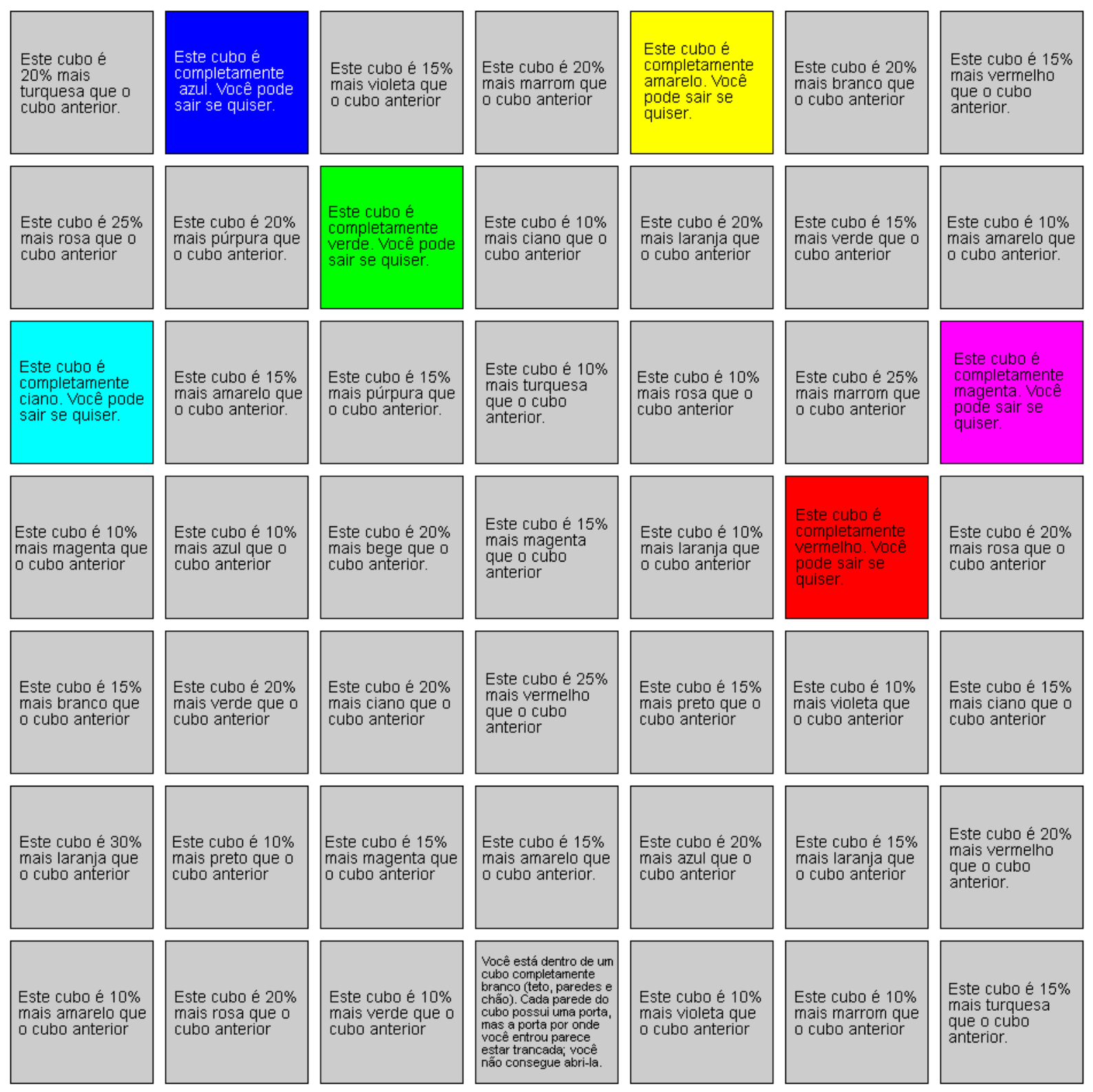

Ilustração 42. Mapa criado durante a realização do trabalho.

Para a definição da estrutura espacial utilizada pelo trabalho, utilizamos a mesma estrutura de Cubo, mantendo a lógica da adição de unidade especiais, mas criando apenas um andar de cubos, não repetindo-os ao longo do eixo vertical.

Seis cubos possuem cores absolutas (como aparecem no mapa acima), e constituem as saídas do labirinto. Ao chegar a um deles, o jogador sempre vê a cor daquele cubo, independentemente da cor anterior e, se digitar o comando sair, ele verá uma animação com todas as cores geradas ao longo de seu percurso. 

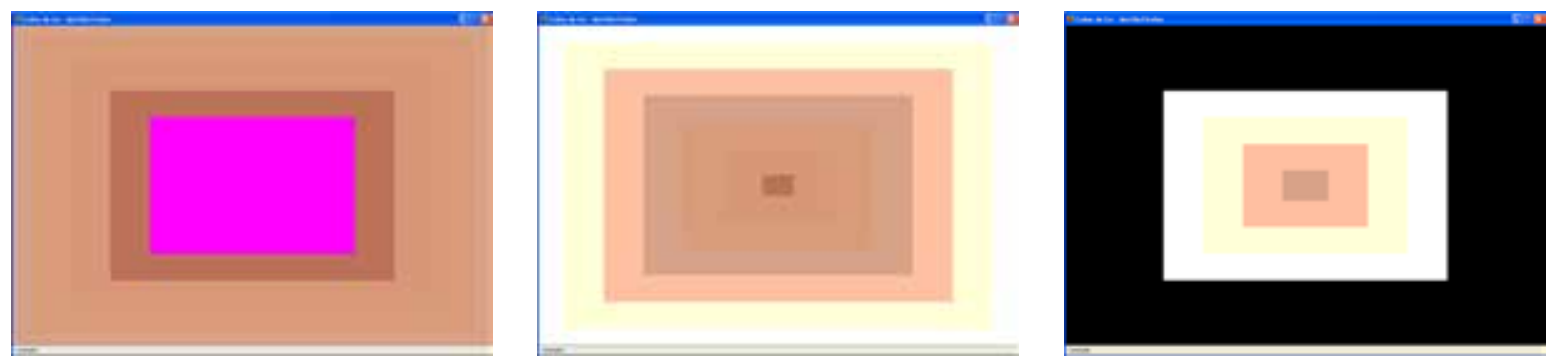

Ilustração 43. Quadros da animação que finaliza Cubos de Cor.

Para criar a animação final, recorremos à idéia de recursão infinita, à qual nos referimos anteriormente, ao discutir o estudo de Grau (1997): são apresentados retângulos em movimento, com a seqüência de cores que representa o seu percurso, que encolhem até sumir da tela. Como as mudanças de cor são relativas, a passagem de uma cor a outra acaba sendo suave (isto é, a única transição brusca representa a entrada na saída), e o resultado termina por remeter à já citada série Homenagem ao Quadrado, de Albers. A seqüência de cores é repetida algumas vezes, para que o jogador tenha a impressão de "uma coisa dentro da outra", de forma quase infinita. Entretanto, optamos por, ao invés de repetir indefinidamente a animação, finalizá-la após 50 retângulos terem sido exibidos na tela; quando o último retângulo some, temos apenas um plano preto, e o jogador não pode executar nenhuma outra ação além de fechar a janela.

Entendemos que a referência a este trabalho de Albers é pertinente pelo fato dele estar interessado em formas de criar a sensação de profundidade sem fazer uso do código da perspectiva. De certo modo, é o que realizamos em Cubos de Cor: provocamos a criação de um espaço, na mente do observador, dando-lhe apenas descrições verbais e planos de cor. Se tomarmos a série Homenagem ao Quadrado como representante de algumas das preocupações e características da pintura modernista (como apontado num dos textos mais conhecidos de Clement Greenberg ${ }^{71}$ ), num sentido mais amplo, a referência a ela se justifica mais uma vez. Afinal, esta pintura rejeitou a representação tridimensional do espaço baseada na perspectiva. E é uma de suas manifestações que nos ajuda a finalizar um trabalho que propõe, o tempo todo, a construção de um espaço (mental), sem oferecer nenhuma representação visual dos cubos. Não há nenhuma imagem que faça uso da perspectiva, com exceção da imagem de abertura. Oferecemos uma oportunidade, sutil, ao espectador: ao ver um dos ícones da pintura modernista, ele pode vir a perceber que tudo o que viu foram apenas planos de cor, sem nenhuma representação visual do espaço que ele criou na sua mente. 




\section{First Person Movements}

O título deste trabalho, composto por um conjunto de animações, faz referência ao gênero de jogos conhecidos como first person shooters, que apresentam a seguinte dinâmica: o jogador deve atirar em tudo que se move enquanto recolhe munição, medicamentos e objetos que lhe permitirão abrir portas e avançar para as etapas seguintes. Os jogos pioneiros deste gênero foram o Wolfenstein $3 D$ e Doom, este último, o seu principal representante. Ambos foram criados pela empresa id Softwa$r e^{72}$

First Person Movements apresenta uma espécide de catálogo dos movimentos que são realizados pelo jogador dentro dos corredores labirínticos ${ }^{73}$ de um first person shooter. Cada movimento é exibido em seis velocidades diferentes, de modo que o observador possa realizar uma análise cuidadosa do mesmo. Antes do conjunto de animações, é exibida uma descrição verbal de cada movimento, como podemos ver nas imagens abaixo.
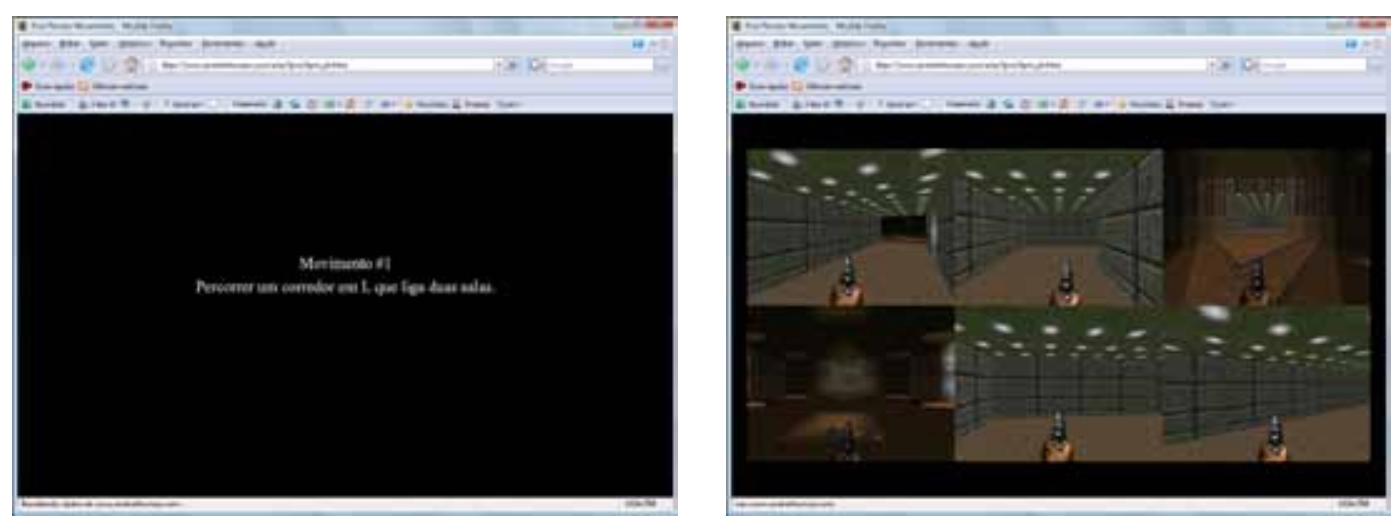

Ilustração 44. À esquerda, descrição do movimento \#1: Percorrer um corredor em L que liga duas salas. À direita, o vídeo com o movimento, em seis velocidades diferentes.

Para a realização deste trabalho, nós utilizamos dois módulos de software distribuídos na modalidade open source. O primeiro é o GZDoom ${ }^{74}$, que é um clone do sistema que roda o jogo Doom. Aqui é preciso abrir um parênteses e explicar que muitos jogos de computador são compostos por duas partes principais: uma é a responsável pelo processamento do jogo em si (ações do usuário, eventos do mundo do jogo, exibição dos gráficos) e a outra consiste no mundo do jogo (cenários,

\section{2 http://www.idsoftware.com/}

73 Maiores informações sobre a presença dos labirintos nos first person shooters podem ser encontradas no segundo capítulo desta dissertação, página 68 .

74 http://grafzahl.drdteam.org 
sons e outros elementos). O mundo do jogo é lido e processado pelo sistema que roda o jogo, conhecido como game engine. Um mesmo game engine pode rodar mundos muito diferentes entre si, e é comum que diversos jogos, comercialmente lançados como produtos independentes, utilizem o mesmo game engine. Game engines são, eles mesmos, softwares complexos, que muitas vezes fazem uso de outros módulos de software.

O segundo módulo utilizado em First Person Movements é o Freedoom ${ }^{75}$, cuja proposta é ser o mundo de um first person shooter completamente open source. Isto é, todos os elementos (imagens, sons e objetos tridimensionais) são distribuídos sob uma licença que permite a sua reutilização e modificação em outros projetos. O Freedoom necessita de uma game engine similar à do Doom para que possa ser jogado; para isso, recorremos ao GZDoom.
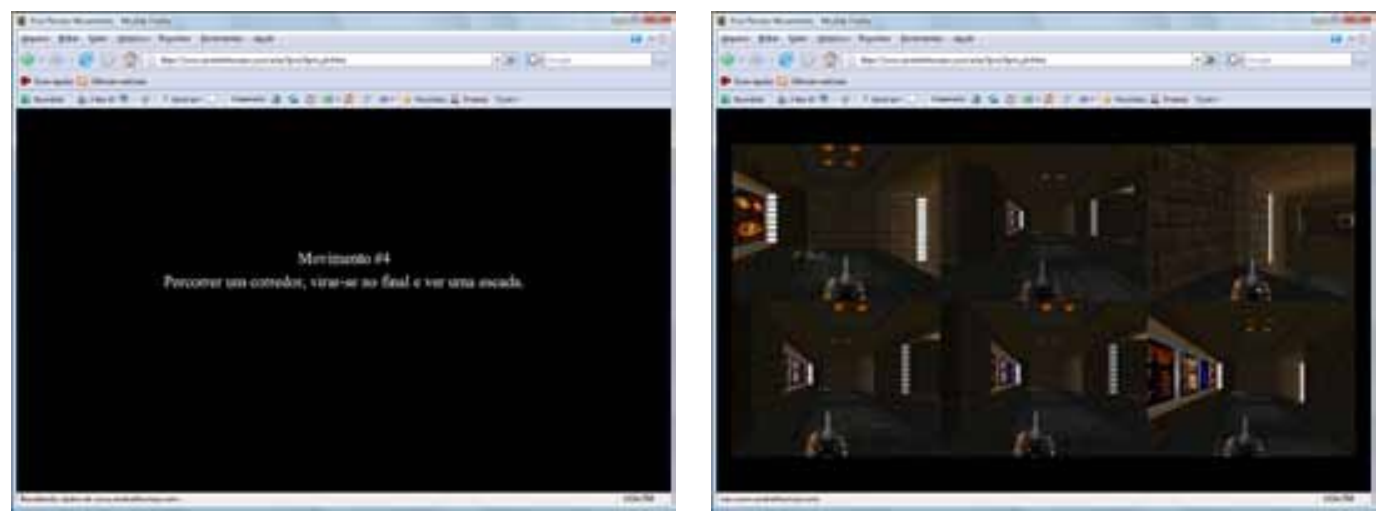

Ilustração 45. À esquerda, descrição do movimento \#4: Percorrer um corredor, virar-se no final e ver uma escada. À direita, os vídeos com o movimento.

Dois conjuntos de trabalhos envolvendo a fotografia constituem as principais referências artísticas de First Person Movements: a cronofotografia, desenvolvida por Etienne-Jules Marey e Eadweard Muybridge, e o trabalho Stop Motion Studies ${ }^{76}$, realizado por David Crawford.

A preocupação com a análise do movimento de seres vivos (onde encontramos a célebre discussão a respeito do galope do cavalo - haveria algum momento em que ele mantém as quatro patas afastadas do solo?) é o ponto comum ${ }^{77}$ entre os trabalhos desenvolvidos por Marey e Muybridge, desenvolvidos na segunda metade do século XIX. Se Muybridge produziu trabalhos em que diferentes fotografias, realizadas em seqüência, são colocados lado a lado, tal como se estivéssemos

$\begin{array}{ll}75 & \text { http://freedoom.sourceforge.net } \\ 76 & \text { http://www.stopmotionstudies.net }\end{array}$

77 Algumas observações sobre as diferenças entre os trabalhos de Marey e Muybridge pode ser encontradas em Godoy-de-Souza (2001, p. 8) e Machado (1997a, p. 67). 
vendo os frames de um filme, a maior parte dos trabalhos de Marey envolve a combinação de diferentes momentos de um movimento na mesma imagem.

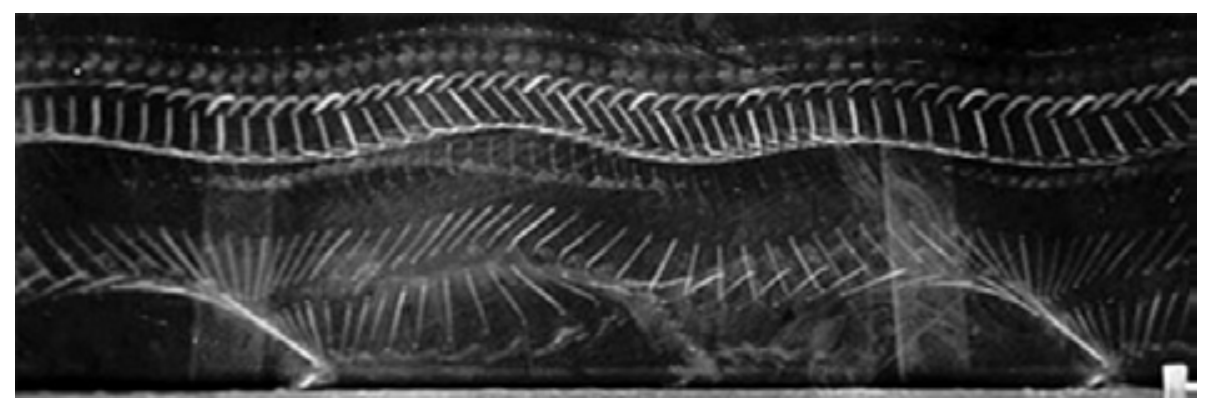

Ilustração 46. Homem correndo, vestido de preto e com linhas brancas, Étienne-Jules Marey.78

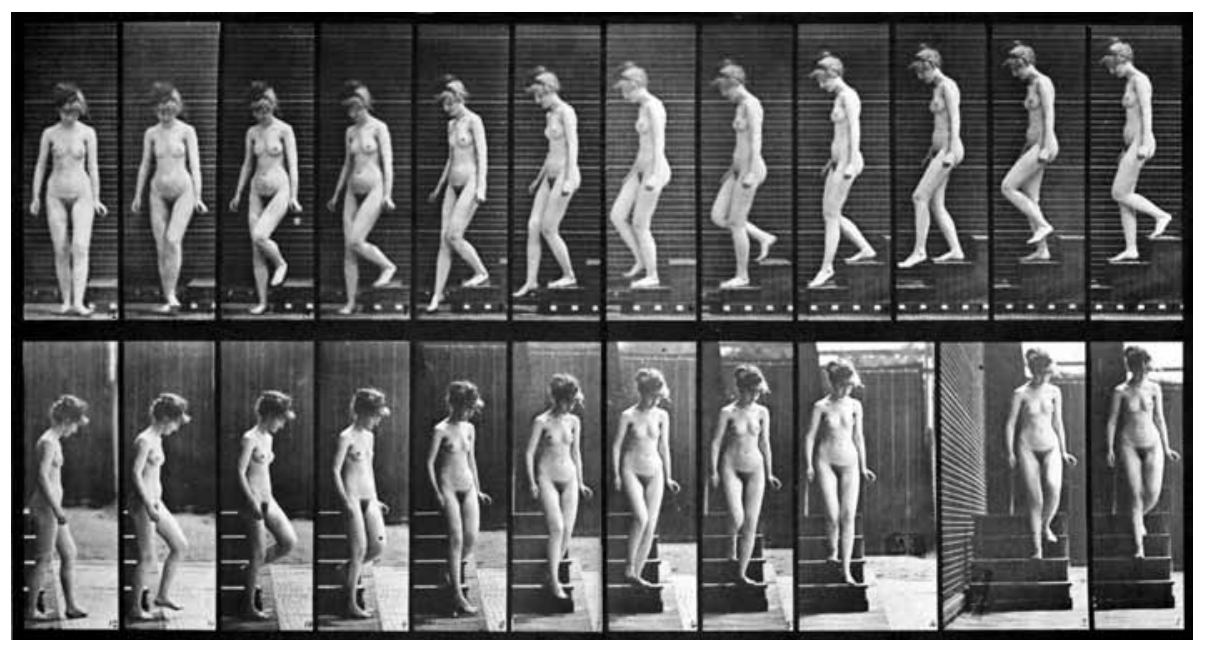

Ilustração 47. Woman walking downstairs, Eadweard Muybridge.79

Para Machado, os procedimentos utilizados por Marey provocam a dissolução das imagens, privilegiando o movimento:

A principal diferença das fotos de Marey em relação àquelas obtidas por seus antecessores está, portanto, no fato de as distintas fases do movimento aparecerem fundidas no mesmo suporte, dando como resultado uma espécie de gráfico do deslocamento do corpo no espaço-tempo. Superpostas as imagens, elas se dissolvem umas nas outras, apagando os próprios contornos e desmaterializando as figuras numa trajetória estilizada. Ademais, Muybridge e Janssen utilizavam intervalos relativamente longos para separar as imagens, de modo a permitir visualizar melhor o que muda de um quadro a outro, ao passo que Marey dedicou todos os seus esforços para estreitar ao máximo esses intervalos e assim poder restituir o movimento em sua continuidade. (...) O que ele buscava era a fusão, a continuidade, enfim, o registro do tempo no espaço.

(MACHADO, 1997a, p. 67)

78 Fonte: site da Cinémathèque Francaise, http://www.cinematheque.fr/marey/center-font-color-8c7853/centerfont-color-8c78531/1160403297.htm. Acesso em 9/05/2008.

79 Fonte: Wikimedia Commons, http://commons.wikimedia.org/wiki/Image:Muybridge-1.jpg. Acesso em $09 / 05 / 2008$. 
Esta observação sobre o trabalho de Marey e o estudo dos trabalhos de Muybridge foram importantes para a opção de utilizarmos pequenos trechos de vídeo, capturados das nossas sessões de jogo com o Freedoom / GZDoom, sem realizar a decomposição em frames (tal como realizamos em alguns estudos de Prince of Persia: Estudos ${ }^{80}$, que será descrito a partir da página 151, nem a sobreposição de imagens, como foi feito em nosso trabalho Another $3 d$ Engine ${ }^{81}$, cuja produção é anterior à realização deste projeto de mestrado.

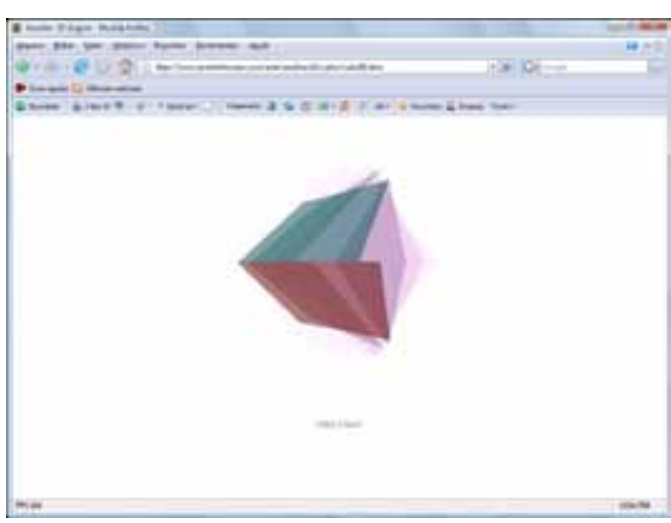

Ilustração 48. Imagem de Another $3 d$ Engine.

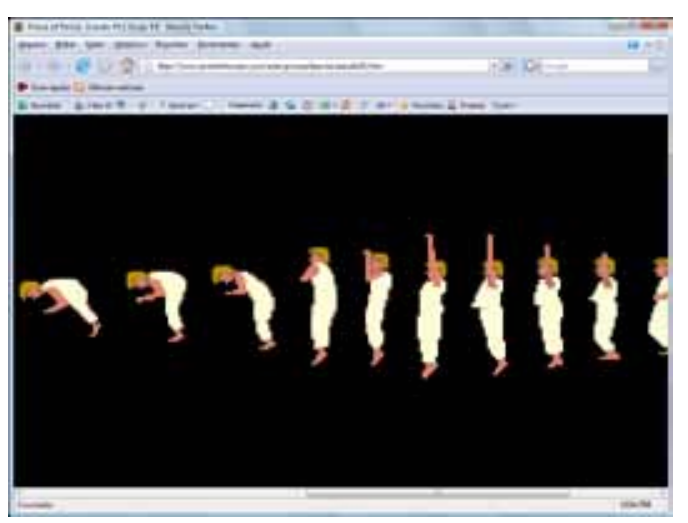

Ilustração 49. Imagem de Prince of Persia: Estudo \#3.

Essa opção é justificada pelo nosso interesse estar na análise do movimento realizado, pelo jogador, dentro dos corredores labirínticos que compõem o cenário do jogo. Assim, não nos interessa dissolver o cenário (tal como ocorreria caso utilizássemos a sobreposição de frames) nem congelar o movimento para analisar alguns de seus momentos. Acreditamos que este seria o resultado da colocação, lado a lado, de imagens estáticas de um movimento, do modo como vemos nos trabalhos de Muybridge.

Por sua vez, David Crawford utiliza, em Stop Motion Studies, fotografias realizadas dentro de metrôs como o seu material de trabalho. Para cada estudo, Crawford seleciona seqüências de 20 imagens, que são exibidas de forma aleatória, quebrando a continuidade das ações registradas por elas. Nas palavras de Curt Cloninger (2005):

Imagine um projetor de slides (...). O projetor exibe os mesmos slides, sem parar, mas sempre numa ordem randômica. O projeto também randomiza a duração de cada slide, oscilando entre .03 segundos a .3 segundos (..). Finalmente, todos os slides na bandeja do projetor contém o mesmo motivo, todos foram fotografados dentro de um determinado intervalo de tempo (menor que dois minutos).(CLONINGER, 2005. Tradução nossa) ${ }^{82}$

80 http://www.andreithomaz.com/arte/princeofpersial

81 http://www.andreithomaz.com/arte/another3d

82 Texto original em inglês: Imagine a slide projector (...). The projector displays these same slides infinitely, but 
De acordo com o depoimento do artista, disponível no site do projeto,

Nestas fotografias, a linguagem corporal das pessoas torna-se a sintaxe básica para uma série de animações que exploram movimento, gestos e montagem algorítmica. Muitas seqüências documentam a reação de uma pessoa ao ser fotografada por um estranho. Algumas sorriem, outras demonstram desagrado, e outras atuam. Algumas fingem não perceber. Por trás de tudo isso, estão suposições e elementos desconhecidos, únicos em cada situação ${ }^{83}$.

(CRAWFORD, 2008. Tradução nossa)

Stop Motion Studies faz uso de recursos de programação em Flash para exibir as imagens em ordem aleatória. De acordo com Cloninger, a não-utilização da ordem inicial das imagens retira a ênfase do movimento para colocá-la nas pessoas e nas suas expressões, o que está de acordo com as intenções, declaradas, do artista.
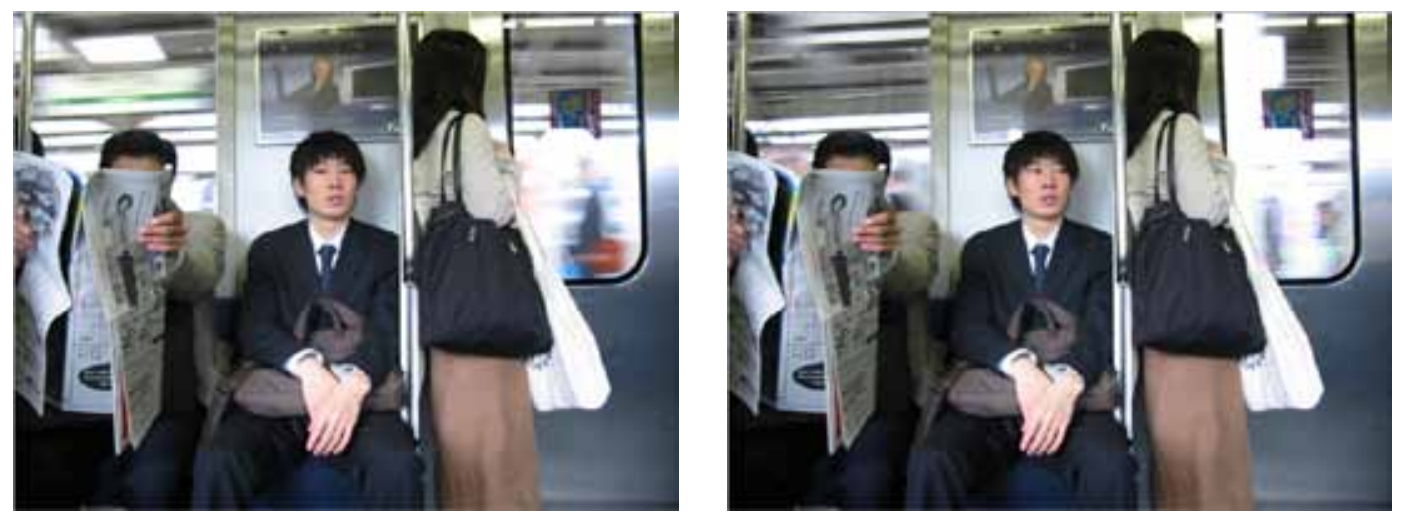

Ilustração 50. Imagens de Stop Motion Studies - Tokyo - Series 8, disponíveis no site do projeto.

A principal contribuição de Stop Motion Studies para a produção de First Person Movements foi a idéia de utilizarmos velocidades diferentes ao apresentar os vídeos capturados nas nossas sessões de jogo. Não pretendíamos interromper o movimento ao longo dos corredores, o que nos fez manter a seqüência das imagens. Porém, ao mesmo tempo, desejávamos incorporar o estranhamento que a alteração na ordem das fotografias, realizadas pela programação de Stop Motion Studies, provoca no espectador. Encontramos na manipulação da velocidade do movimento a maneira de interrogar o espectador, que fica sem saber qual das seis possibilidades corresponde à velocidade

always in random order. The projector also randomizes the duration each slide is displayed, anywhere from .03 seconds to .3 seconds (...). Finally, all the slides in the tray are of the same subject, all photographed within a limited time frame (less than two minutes).

83 Texto original em inglês: In these photographs, the body language of the subjects becomes the basic syntax for a series of animations exploring movement, gesture, and algorithmic montage. Many sequences document a person's reaction to being photographed by a stranger. Some smile, others snarl, still others perform. Some pretend not to notice. Underneath all of this are assumptions and unknowns unique to each situation. 
original dos movimentos executados pelo jogador / câmera. Esta variação também permite que, nas alternativas mais rápidas, o enfoque caia no deslocamento em si, enquanto que nas mais lentas o espectador possa prestar mais atenção ao cenário e aos seus elementos. 



\section{Eclipses}

O interesse comum por mapas urbanos foi o que motivou a produção deste trabalho ${ }^{84} \mathrm{em}$ parceria com a artista Marina Camargo ${ }^{85}$. Eclipses consiste num software que utiliza mapas originários do Google Maps, para criar imagens a partir da combinação dos mesmos.

Inicialmente, uma lista de nomes de ruas é apresentada ao interator. Quando este seleciona um nome, o software busca a lista de cidades que possuem uma rua com o nome selecionado; a partir dessa lista, o mapa de cada ocorrência da rua é exibido, com os mapas sendo centralizados na rua selecionada. Após a apresentação dos mapas, o software gera uma imagem, sobrepondo as malhas de ruas de cada mapa, desenhadas em preto. O nome Eclipses surge, então, a partir do alinhamento entre os mapas em função da rua selecionada, e do apagamento que é realizado quando os mapas são combinados.

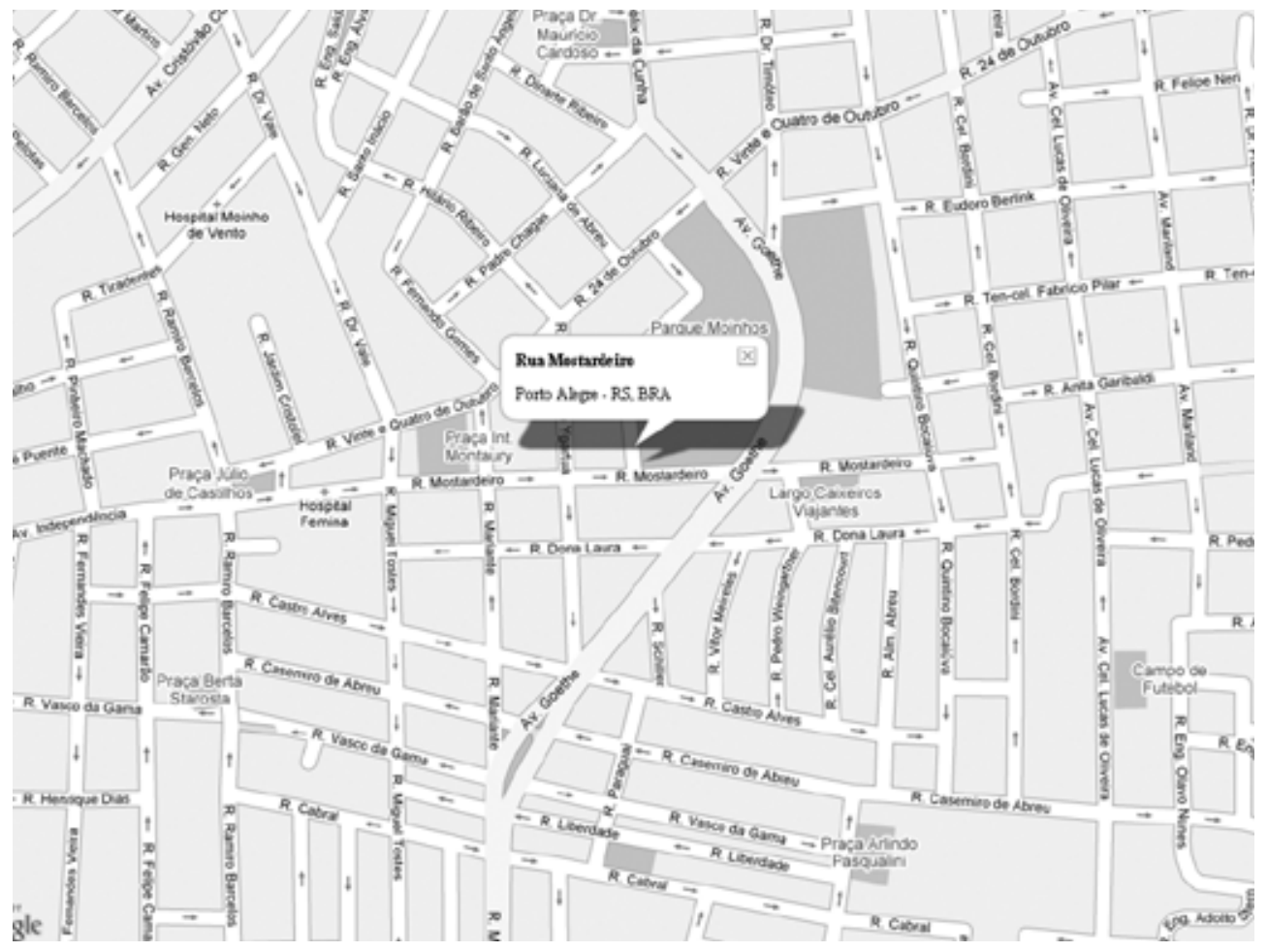

Ilustração 51. Mapa que mostra a Rua Mostardeiro na cidade de Porto Alegre, RS.

84 Disponível para download em http://www.percursos.com.br/

85 Maiores informações sobre a produção artística de Marina Camargo podem ser encontradas em http://www. marinacamargo.com/ 


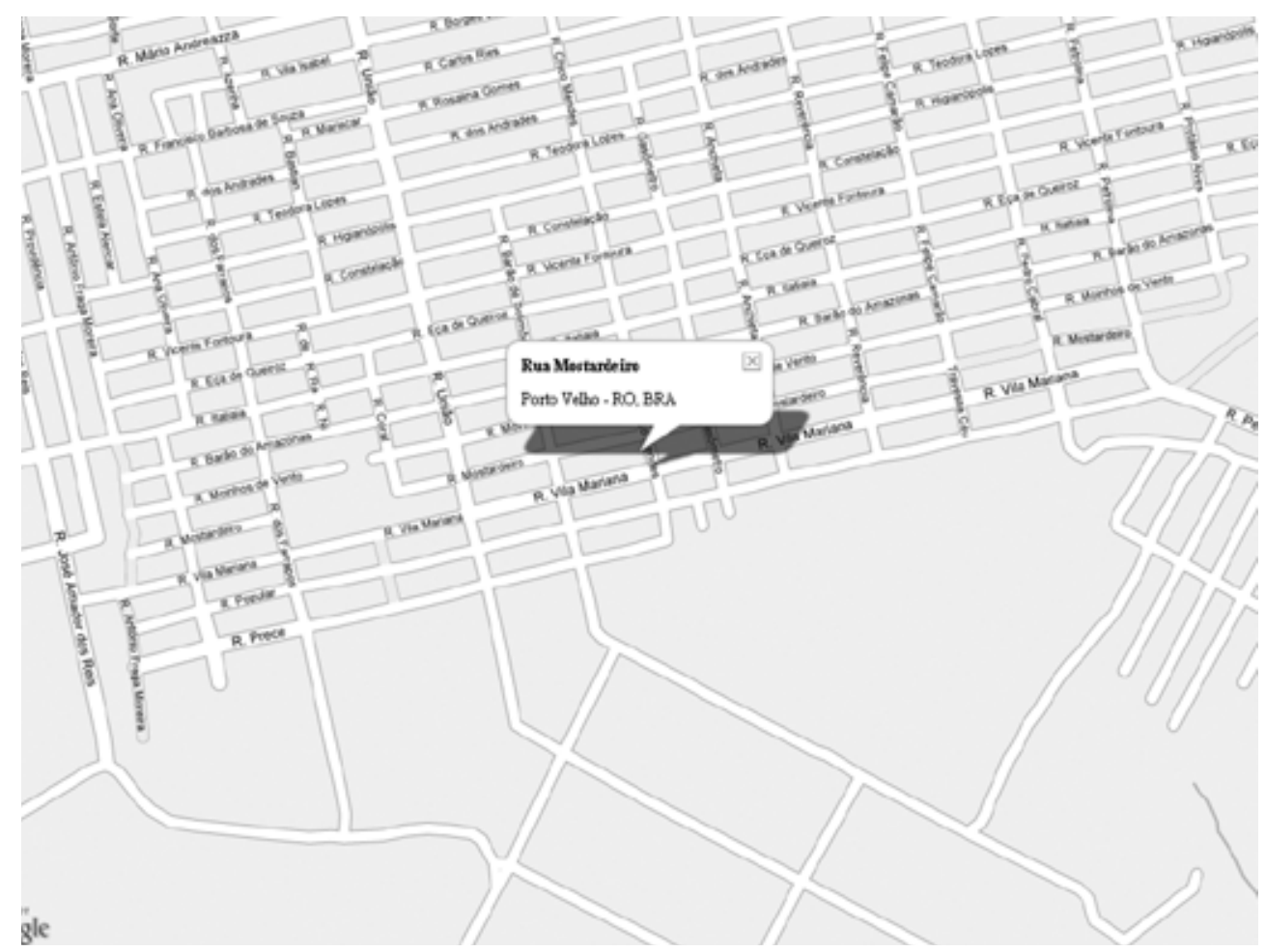

Ilustração 52. Mapa que mostra a Rua Mostardeiro na cidade de Porto Velho, RO.

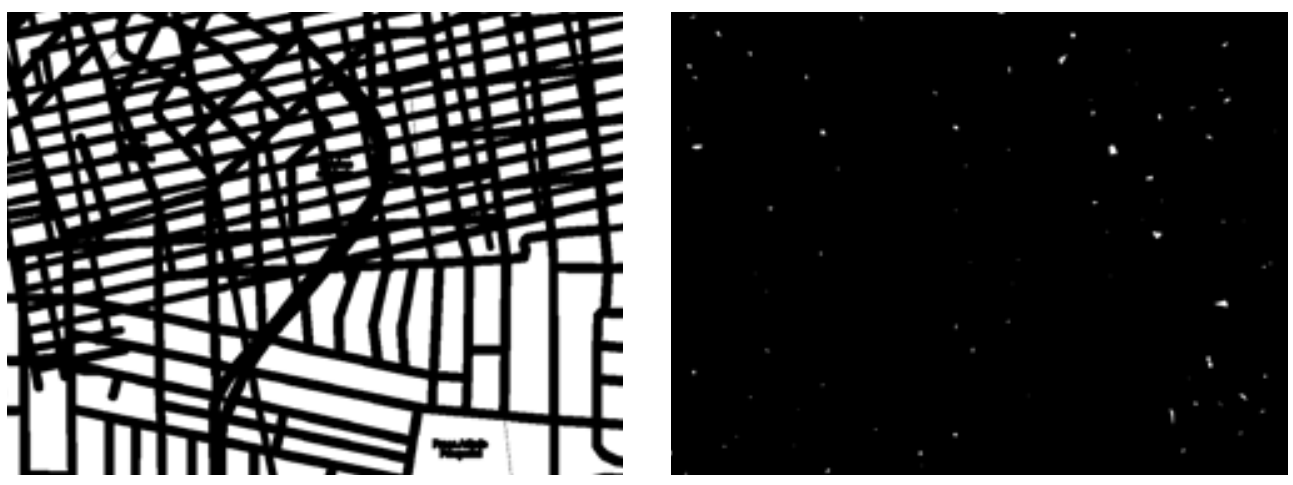

Ilustração 53. Combinação do mapa com a Rua Mostardeiro em Porto Alegre e em Porto Velho (à esq.). Combinação dos mapas com as ocorrências da Rua Ramiro Barcelos (onze ruas com este nome foram encontradas nas cidades brasileiras, à dir.).

No seu estudo sobre a arquitetura dos espaços criados por Borges, Cristina Grau dedica um capítulo à idéia da cidade como um labirinto, e é esta associação que está por trás do nosso interesse pelos mapas urbanos. Eles nos permitem perceber as características labirínticas do espaço da cidade, a sua complexidade e a resistência que as metrópoles oferecem à criação de uma magem global delas mesmas. Grau inicia esta seção do seu estudo citando um trecho de Aben Hakam, o Bokari, morto em seu labirinto, no qual Borges assinala os aspectos labirínticos da cidade de Londres e do próprio universo:

Um fugitivo não se esconde num labirinto. (...) Não precisa construir um labirinto, quando o universo já é um. Para quem verdadeiramente quer se esconder, Londres é um labirinto 
melhor que um mirante onde vão dar todos os corredores de um edifício.

(BORGES, 2008b, p. 118. Grifos nossos.)

Antes de propor algumas relações entre as cidades de Borges, principalmente entre a Cidade dos Imortais e os espaços labirínticos criados por Piranesi (que culminam na série Os Cárceres), Grau faz uma observação importante sobre quais seriam as cidades com um caráter labiríntico mais pronunciado:

\begin{abstract}
Não há dúvidas que não se poderá aplicar este adjetivo à cidade clássica, à cidade renascentista ou à cidade neoclássica, ou às cidades norte-americanas cujas ruas formam uma trama quadricular; tampouco às cidades utópicas de Hilbersheimer ou de Le Corbusier, resultados de uma idéia anterior ou de um planejamento. Ele só poderá ser aplicado à cidade que é resultado da justaposição de fragmentos distintos, de crescimentos sucessivos, de repetições equivocadas. Aquela cidade da qual, apesar de conhecê-la, somos incapazes de criar um mapa; não é possível desenhá-la em sua totalidade. (GRAU, 1997, p. 126) ${ }^{86}$
\end{abstract}

Gostaríamos, entretanto, de introduzir uma diferenciação que está ausente do texto de Grau sobre a cidade como labirinto mas que é recorrente na nossa bibliografia sobre o mesmo. É a idéia de que o labirinto, mais do que um signo da desordem, é um símbolo da complexidade, como já foi dito no primeiro capítulo desta dissertação. Esta diferenciação é importante, porque ela pode orientar uma aproximação mais produtiva de análises do espaço e da paisagem urbana, tais como a efetuada por Kevin Lynch em A Imagem da Cidade (1988).

Nesse livro, o autor propõe uma maior preocupação com a "imaginabilidade" e a "legibilidade" das cidades, realizando estudos, em três cidades norte-americanas, sobre a forma como os seus habitantes as percebem e criam imagens das cidades em que eles vivem. Trazendo tais termos para a nossa discussão sobre o labirinto, podemos dizer que Lynch se preocupa com a possibilidade dos habitantes de uma cidade elaborarem imagens globais do local onde vivem. Para nós, uma das características mais interessantes do estudo de Lynch é o fato dele não ignorar, nem pretender acabar com, a complexidade intrínseca ao espaço urbano. Para ele, "a complexidade da cidade moderna (...) também fornece prazer". Em relação ao labirinto, afirma:

Temos de admitir que há algum valor na mistificação, no labirinto ou surpresa no meio ambiente: muitos de nós divertimo-nos na sala dos espelhos e há um certo encanto nas ruas sinuosas de Boston. Contudo, estes fatos verificam-se sob duas condições. Primeiramente, não deve existir o perigo de se perder a forma básica, a orientação, ou de não encontrar uma saída. A surpresa deve ocorrer num trabalho de organização absoluta; as confusões devem traduzir-se em pequenas áreas num todo visível. Para além disto, o labi-

86 Texto original em espanhol: Sin embargo no es a la ciudade clásica, renacentista o neoclásica a la que se podrá aplica esta denominación, o a las ciudades americanas de trama em cuadrícula; tampoco a las ciudades utópicas de Hilbersheimer o de Le Corbusier, productos de uma imagen previa o de uma planificación, sino a la ciudade generada por yuxtaposición de distintos fragmentos, de adiciones sucesivas, de repeticiones equívocas. La ciudad que aunque conocemos, somos sin embargo incapaces de hacer un esquema de ella; no es posible dibujarla en su totalidade. 
rinto ou mistério deve encerrar em si alguma forma que pode ser analisada e, a seu tempo, apreendida. $\mathrm{O}$ caos completo sem insinuações de relações nunca pode ser agradável.

(LYNCH, 1988, pp. 15-6. Grifo nosso)

Deste modo, acreditamos que a pesquisa sobre a complexidade do espaço urbano e dos seus mecanismos de orientação consiste na melhor forma de aproximação dos aspectos labirínticos da cidade, mais do que o foco na desordem e nos aspectos caóticos da urbe, que são, para Lynch, agentes desintegradores da vivência urbana. 
(1) 1 位 (1)

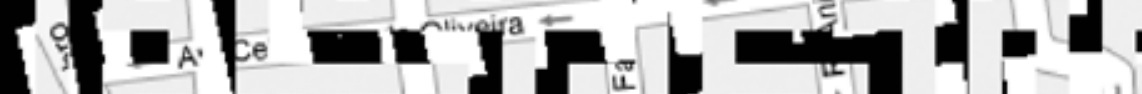

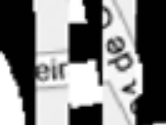
$\prod_{1}$ $1+5$ thenth Tin

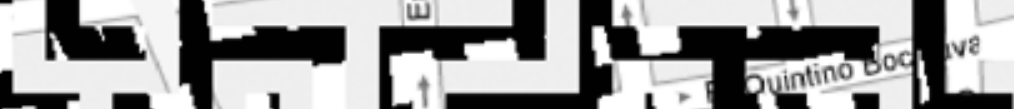

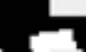
rind L

$1-241$ t alii tivint (ii) 1 - 1 os $11:=1$

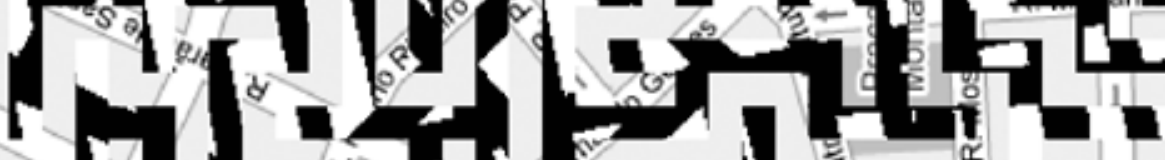

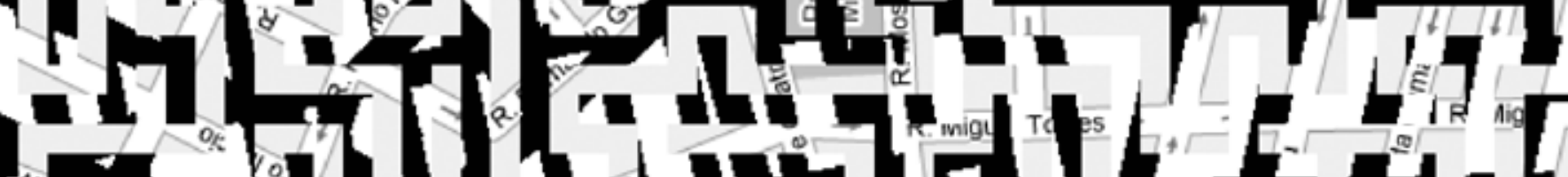
-

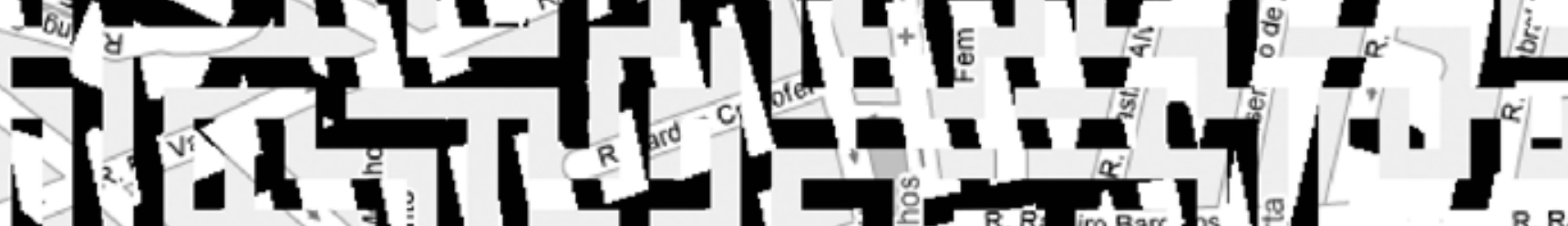

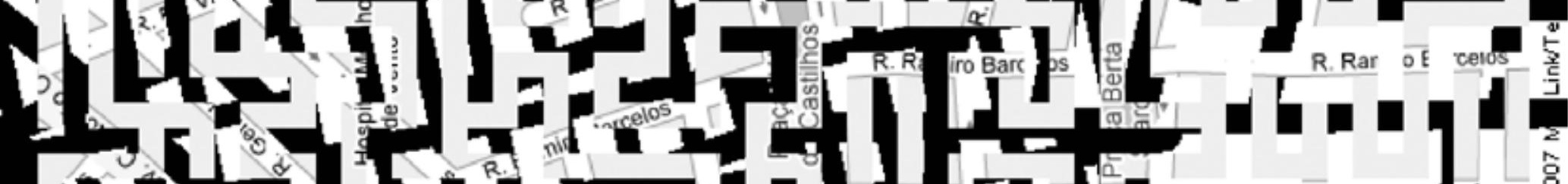

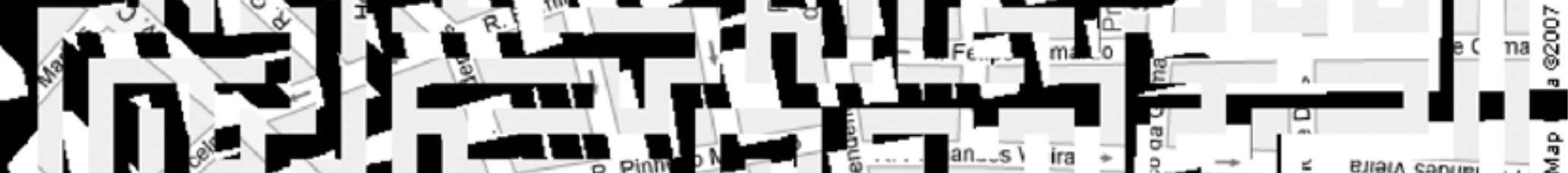

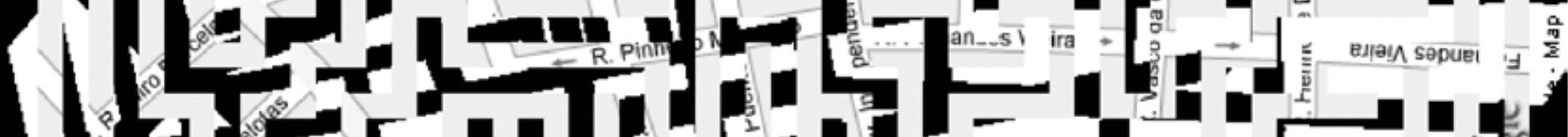

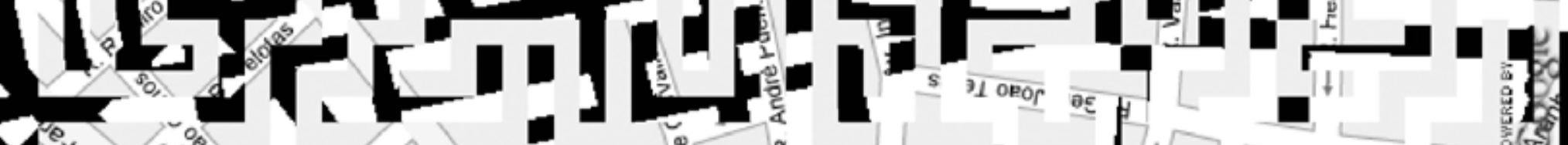





\section{Labirintos temporais: o tempo nos jogos eletrônicos e algumas experiências temporais em outras mídias}

Para estudar a experiência do tempo nos jogos eletrônicos, tomamos como ponto de partida os textos da nossa bibliografia que abordam, em algum momento, esta questão ${ }^{87}$. Ao contrário do cinema e da literatura, que possuem uma vasta fortuna crítica dedicada ao assunto, os jogos eletrônicos possuem poucos estudos dedicados seja ao tempo, seja a outros aspectos. Um dos temas que recebeu a atenção dos pesquisadores, de forma mais intensa, é a relação entre jogo e narrativa, que gerou todo um debate entre teóricos que defendiam a abordagem dos jogos eletrônicos a partir das teorias da narrativa e aqueles que defendiam que a narrativa teria uma importância secundária para o estudo dos mesmos jogos ${ }^{88}$. E é desse debate que a maioria dos textos utilizados neste capítulo é originária.

Antes de prosseguir, gostaríamos de observar que não é objetivo desta pesquisa, nem deste capítulo, analisar o mérito dessa discussão. Além disso, o próprio debate vem se transformando.

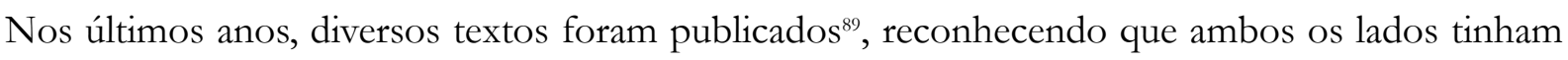
a sua parcela de razão: há elementos narrativos nos jogos, em graus variáveis, ao mesmo tempo em que os estudos sobre a narrativa não são suficientes para abordar as especificidades dos jogos eletrônicos. Para exemplificar, tomemos como exemplo o caso de Jesper Juul, teórico dinamarquês que, num artigo publicado em $2005^{90}$, comenta o assunto da seguinte forma:

(...) Uma narrativa pode ser utilizada para dizer ao jogador o que ele deve fazer, ou pode ser dada como uma recompensa por avançar no jogo. Jogos eletrônicos podem conter elementos narrativos que um jogador pode utilizar para contar a outros jogadores o que ocorreu numa sessão de jogo. Pode-se dizer que jogos eletrônicos e narrativas possuem alguns pontos em comum. Isso realmente significa que a posição extrema de alegar que jogos eletrônicos e narrativas não podem ser, de forma alguma, relacionados (um

87 Tais como artigos dos livros organizados por Noah Wardrip-Fruin e Pat Harrigan (2003), Mark Wolf e Bernard Berron (2003), Mark Wolf (2002), Katie Salen e Eric Zimmerman (2006), Joost Raessens e Jeffrey Goldstein (2005), assim como textos de Espen Aarseth (1999), Alexander Galloway (2006), Arlindo Machado (1997b) e Jesper Juul (1999).

88 Este debate pode ser encontrado nos livros citados acima.

89 JENKINS, Henry. Game Design as Narrative Architecture. In: SALEN, Katie; ZIMMERMAN, Eric (ed). The Game Design Reader - A Rules of Play Anthology. Massachussets; London: The MIT Press, 2006. pp. 670-689. MATEAS, Michael; STERN, Andrew. Interaction and Narrative. In: SALEN, Katie; ZIMMERMAN, Eric (ed).

The Game Design Reader - A Rules of Play Anthology. Massachussets; London: The MIT Press, 2006. pp. 642669.

JUUL, Jesper. Games Telling Stories? In: RAESSENS, Joost, GOLDSTEIN, Jeffrey. Handbook of Computer Game Studies. Cambridge, Massachussets; London: The MIT Press, 2005. pp. 219-226.

$90 \quad$ Ver nota anterior para referência completa do artigo. 
texto de mim mesmo, Juul, 1999, é um bom exemplo) é insustentável.

(JUUL, 2005, p. 220. Tradução e grifos em negrito são nossos ${ }^{91}$; grifos em itálico são do autor. Ver nota 89 para referência completa do artigo.)

No final do artigo, ele conclui:

Utilizando outros meios como ponto de partida, nós podemos aprender muitas coisas sobre a construção de mundos ficcionais, personagens... Mas concentrar-se excessivamente em teorias já existentes nos fará esquecer o que faz de um jogo um jogo: elementos como regras, objetivos, ações do jogador, a representação destas ações no espaço do jogo, a forma como o jogo define as ações possíveis do jogador. São estas especificidades que nós precisamos estudar agora.

(JUUL, 2005, p. 225, tradução e grifo nossos ${ }^{92}$. Ver nota 89 para referência completa do artigo.)

\subsection{O tempo nos jogos eletrônicos}

Na bibliografia consultada, encontramos duas posições principais em relação ao tempo nos jogos eletrônicos. A primeira defende a idéia de que o tempo nos jogos é uma espécie de presente contínuo, um tempo que sempre corre em direção ao futuro; seu representante principal é Juul. Já a segunda posição surge como uma crítica às análises de Juul, com o argumento de que há jogos eletrônicos que envolvem idas e vindas no tempo. Encontramos esta crítica em Henry Jenkins (2005) ${ }^{93}$ e Michael Mateas e Andrew Stern (2006) ${ }^{94}$.

Em Juul (2005, p. 223), o autor afirma que no jogo é sempre agora. Um jogo pode fazer referência a ações passadas ou futuras, utilizar alguma forma de mapeamento do tempo ${ }^{95}$ (como o que ocorre em The Sims ${ }^{96}$, em que o tempo pode ter a sua velocidade alterada pelo jogador) ou possuir elipses ${ }^{97}$, mas a ação do usuário se dá no momento atual. Tomemos como exemplo o jogo Prince of Persia, já citado no capítulo anterior. O personagem principal, controlado pelo jogador,

91 Texto original em inglês: (...) A narrative may be used for telling the player what to do or as rewards for playing. Games may spawn narratives that a player can use to tell others of what went on in a game session. Games and narratives can on some points be said to have similar traits. This does mean that the strong position of claimin games and narratives do be completely unrelated (my own text, Juul, 1999, is a good example) is untenable.

92 Texto original em inglês: Using other media as starting points, we may learn many things about the construction of fictive worlds, characters... but relying too heavily on existing theories will make us forget what makes games games, such as rules, goals, player activity, the projection of the player's actions into the game world, the way the game defines the possible actions of the player. It is the unique parts that we need to study now.

93 Ver nota 89 para referência do artigo.

94 Idem.

95 Juul desenvolve a noção de mapeamento do tempo em JUUL, Jesper. Introduction to Game Time / Time to Play. In: WARDRIP-FRUIN, Noah; HARRIGAN, Pat (ed.). First Person. New Media as Story, Performance, and Game. Cambridge, Massachussets - London: The MIT Press, 2004. p. 134.

96 Para uma descrição da manipulação do tempo em The Sims, ver (ROLLING; ADAMS. 2003, pp. 66-67).

97 Para uma observação sobre a elipse nos jogos eletrônicos, ver Gosciola (2003, pp. 125-126). 
deve salvar a princesa das garras do vizir Jafar, com quem ela será obrigada a se casar. Ao iniciar o jogo, uma seqüência de telas é exibida, narrando a história da princesa. Ficamos sabendo que o vizir prendeu o nosso herói nas masmorras do castelo onde vive a princesa, e que ele possui uma hora para salvá-la. Não é possível saber como o nosso herói foi preso, nem voltar no tempo para evitar a sua captura; a narrativa serve apenas para contextualizar as nossas ações (passado) e para estabelecer os nossos objetivos (futuro). Essa estrutura é encontrada em quase todos os jogos eletrônicos, com diferentes graus de elaboração; isto é, em alguns temos o contexto e os objetivos descritos de forma mínima, enquanto que, em outros, a origem do personagem do jogador e os seus possíveis futuros (em caso de vitória ou de derrota) são apresentados de formas bem mais elaboradas, com vídeos de alta qualidade (se comparados aos gráficos dos jogos) e narrações (áudio).

É a possibilidade do usuário agir (na verdade, obrigatoriedade), que faz com que Juul analise o tempo do jogo como sendo sempre o presente:

Se nós jogamos um jogo de ação como Doom II (ID Software, 1994), dificilmente encontraremos uma separação entre tempo de história, tempo da narrativa, e tempo de leitura/visualização. Nós podemos encontrar uma representação, e como jogador você tenta reconstruir alguns eventos desta representação. (...)

É evidente que os eventos representados não podem ser anteriores ou posteriores, já que, como jogadores, nós podemos alterá-los. Ao pressionar a tecla CTRL, nós disparamos com a arma selecionada, o que altera o mundo do jogo. Neste sentido, o jogo constrói o tempo da história de forma síncrona com o tempo da narrativa e com o tempo de leitura/visualização: o tempo da história é agora. Agora, não apenas no sentido de que o observador assiste aos eventos agora, mas no sentido de que os eventos estão acontecendo agora, e que o que virá depois ainda não está determinado.

Num jogo do tipo "história interativa", onde o usuário assiste a clipes de vídeo e, ocasionalmente, faz alguma escolha, o tempo da história, o tempo da narrativa e o tempo da leitura/visualização correm de forma independente, mas, quando o usuário pode agir, eles necessariamente precisam implodir: é impossível mudar o curso de algo que já ocorreu. Isso significa que você não pode ter interatividade e narração ao mesmo tempo. $\mathrm{E}$ isso significa que, na prática, os jogos quase nunca realizam operações narrativas básicas como flashback e flashforward. Os jogos são quase sempre cronológicos.

(JUUL, 2005, p. 223. Tradução nossa ${ }^{98}$. Grifos em itálico são do autor, grifos em negrito são nossos. Ver nota 89 para referência completa do artigo.)

98 Texto original em inglês: If we then play an action-based game such as Doom II (ID Software, 1994), it is hard to find a distance between story time, narrative time, and reading/viewing time. We may find a representation, and as a player you try to reconstruct some events from this representation. (...)

It is clear that the events represented cannot be past or prior, because we as players can influence them. By pressing the CTRL key, we fire the current weapon, which influences the game world. In this way, the game constructs the story time as synchronous with narrative time and reading/viewing time: the story time is now. Now, not just in the sense that the viewer witnesses events now, but in the sense that the events are happening now, and that what comes next is not yet determined.

In an "interactive story" game where the user watches video clips and occasionally makes choices, story time, narrative time, and reading/viewing time will move apart, but when the user can act, they must necessarily implode: it is impossible to influence something that has already happened. This means that you cannot have interactivity and narration at the same time. And this means in practive that games almost never perform basic narrative operations such flashback and flashfoward. Games are almost always chronological. 
Uma das poucas objeções que encontramos a essa visão do tempo do jogo como sendo um presente contínuo é encontrada no artigo de Jenkins, Game Design as Narrative Architecture:

\begin{abstract}
Tomando Quake como exemplo, Jesper Juul argumenta que flashbacks são impossíveis nos jogos, porque os jogos sempre ocorrem em tempo real. Mais uma vez, isto é confundir estória e enredo. Os jogos eletrônicos não estão mais presos a um presente eterno do que os filmes estão condenados a serem sempre lineares. Muitos jogos possuem momentos de revelação, ou elementos que esclarecem ações e eventos anteriores. (JENKINS, 2006, p. 682. Tradução e grifo nossos ${ }^{99}$. Ver nota 89 para referência completa do artigo.)
\end{abstract}

Histórias de detetive, como nos lembra Jenkins, possuem duas narrativas: a narrativa da investigação, e a história sendo reconstituída (JENKINS, 2006, p. 681). Podemos encontrar este modelo em diversos jogos eletrônicos em que a tarefa principal do jogador é procurar informações e concatená-las, como se estivesse montando um quebra-cabeça. Um dos exemplos mais conhecidos é o já citado Myst. ao longo do seu percurso, que não será rápido, pela ilha, o jogador poderá entender os acontecimentos passados do lugar, e que fizeram dele uma ilha desabitada.

Além das histórias de detetive, outro exemplo em que o jogo retoma acontecimentos passados são os momentos nos quais o jogador pode rever algumas de suas ações e/ou momentos anteriores do jogo. É o caso do álbum de fotografias de The Sims e de seqüências similares aos replays das transmissões televisivas de jogos esportivos. Tais seqüências constituem, em muitos casos, o que Mateas e Stern (2006, p. 644) chamam de narrativas emergentes ${ }^{100}$ : o jogador pode rever a narrativa da qual ele participou ao longo das horas de jogo e que "emergiu" a partir desta experiência. As imagens da partida são, muitas vezes, combinadas com imagens e vídeos pré-existentes, que ajudam a relacionar as ações do jogador com a narrativa principal do jogo.

99 Texto original em inglês: Using Quake as an example, Jesper Juul argues that flashbacks are impossible within games, because the game play always occurs in real time. Yet, this is to confuse story and plot. Games are no more locked into an eternal present than films are always linear. Many games contain moments of revelation or artifacts that shed light on past actions.

100 Ao contrário de abordar as narrativas como experiências cuidadosamente elaboradas por um autor, para o consumo de uma audiência, as narrativas emergentes preocupam-se em oferecer um contexto rico, onde cada jogador, individualmente, possa construir as suas próprias narrativas, ou onde grupos de jogadores possam envolver-se na construção social e coletiva de narrativas.

(MATEAS e STERN, 2006, p. 644. Tradução nossa. Ver nota 85 para referência completa do artigo.) 


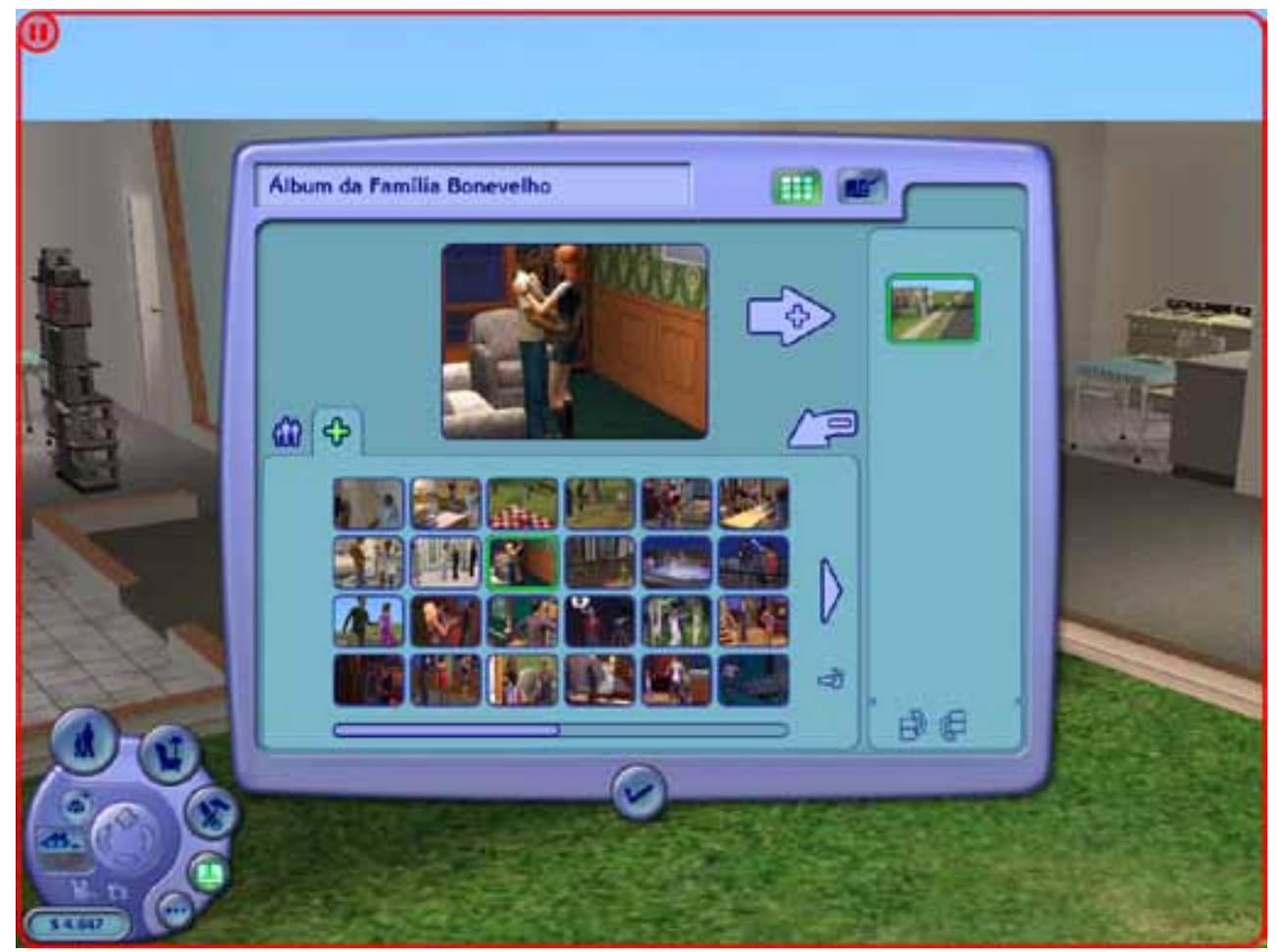

Ilustração 54. Álbum de fotografias dos personagens de The Sims 2

\subsection{O tempo das múltiplas sessões de jogo e a possibilidade de salvá-lo}

Saindo das fronteiras do jogo em si, podemos encontrar outra forma de manipulação do tempo. É a possibilidade de voltar atrás para testar outras possibilidades de ação dentro do jogo. Volta que é, normalmente, motivada pela derrota; o jogador reinicia o jogo para agir de forma diferente, a fim de atingir a vitória ou de, pelo menos, conseguir avançar um pouco mais no jogo. Jogos mais complexos costumam permitir que o jogo seja salvo a qualquer momento, de modo que, se o jogador "morre" no jogo, ele não precisa reiniciar do zero.

Esta forma de manipulação do tempo será melhor analisada a partir de algumas formas temporais que buscamos nos campos da literatura e do cinema, que nos fornecem exemplos mais radicais de uso do tempo.

\subsection{Outras possibilidades de formas temporais}

Um dos raros desenvolvimentos de uma estruturação menos convencional do tempo dentro dos jogos eletrônicos pode ser encontrado no projeto O Cožinheiro das Almas ${ }^{101}$, jogo experimen-

101 http://www.cap.eca.usp.br/poeticas/?page_id=28 
tal desenvolvido por integrantes ${ }^{102}$ do Grupo de Pesquisa Poéticas Digitais ${ }^{103}$, sob a coordenação de Gilbertto Prado. O jogo utiliza como narrativa inicial o livro "O Perfeito Coz̧inheiro das Almas deste Mundo, diário da garçonnière mantida por Oswald de Andrade entre 1918 e 1919”'104, e propõe ao interator a navegação por diversos cenários, cada um num período de tempo diferente, sendo que alguns cenários podem ser visitados em mais de um tempo. Isto é, o jogador tem como ir e voltar no tempo na medida que ele "é arremessado de lugar para lugar independentemente de sua vontade" ${ }^{\prime 105}$. Infelizmente, por questões de limites dos recursos de produção, apenas dois módulos do jogo foram desenvolvidos até o momento.
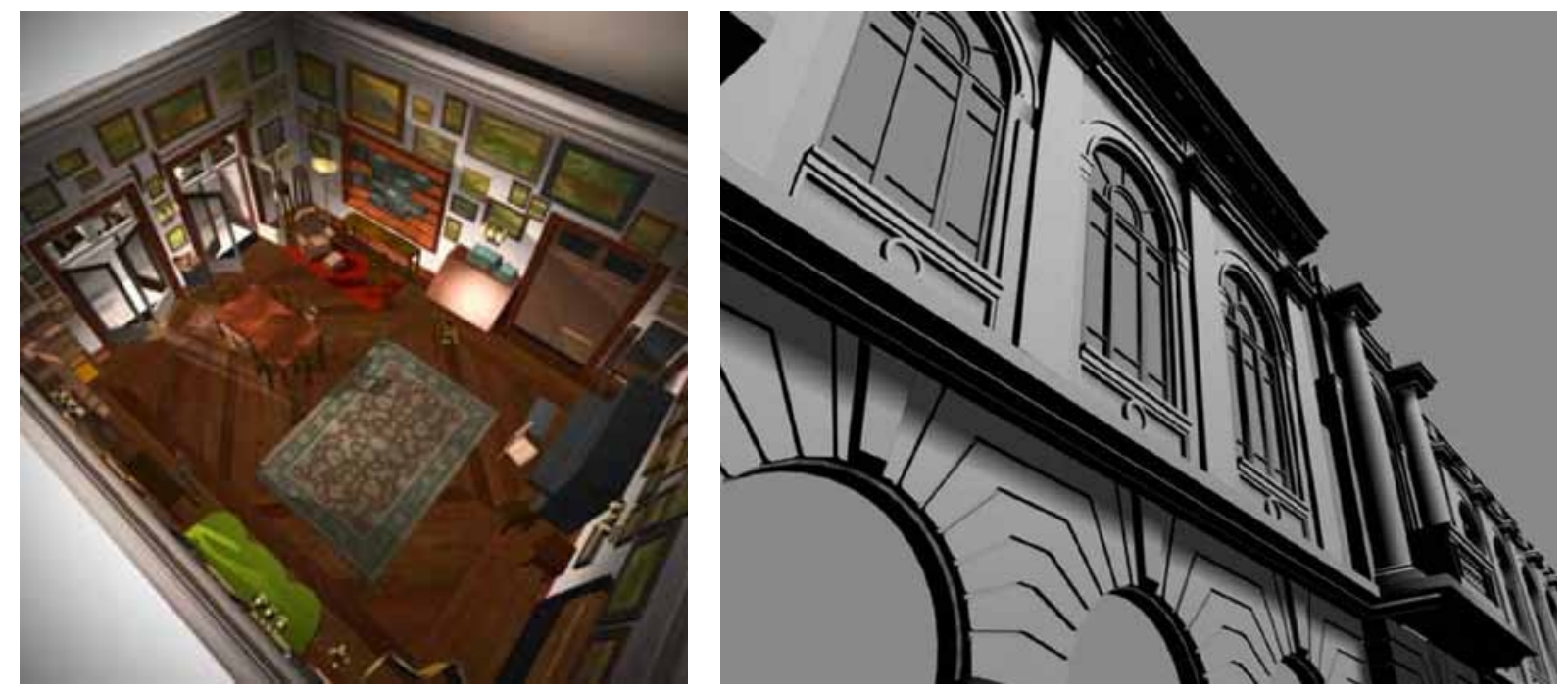

Ilustração 55. Os dois ambientes de $O$ Cozinheiro das Almas, já implementados: à esquerda, a garçonnière; à direita, a Escola Normal (atualmente, prédio da Secretaria da Educação, Praça da República, São Paulo).

Desta forma, devido à escassa experimentação com o uso do tempo nos jogos eletrônicos, procuramos em filmes, textos literários e estudos sobre as novas mídias formas de utilizar o tempo onde pudéssemos encontrar traços labirínticos. Esta pesquisa não foi exaustiva; nosso objetivo foi o de ter elementos que nos permitissem desenvolver uma investigação sobre a presença e/ou criação de labirintos temporais no universo dos jogos eletrônicos, investigação que se torna parte do universo de elementos a partir dos quais nossos trabalhos artísticos são desenvolvidos.

102 Coordenação: Gilbertto Prado; Argumento: Jesus de Paula Assis; Roteiro: Jesus de Paula Assis, Paula Janovitch e Gilbertto Prado; Design: Lívia Gabbai, Luciano Gosuen e Tomas Sniker; Vídeo: Maurício Taveira, Luciano Gosuen e Fábio Oliveira Nunes; Programação: Marcos Cuzziol, John-Philip Johansson, André Furlan, Gaspar Arguello e Eliane Oliveira.

103 O grupo de pesquisa Poéticas Digitais desenvolve suas atividades na Escola de Comunicação e Artes da USP, com a coordenação de Gilbertto Prado e Silvia Laurentiz. Site: http://www.cap.eca.usp.br/poeticasdigitais/.

104 Conforme descrição disponível no site do projeto. Acesso em 17/05/2008.

105 Idem. 
A partir desta pesquisa, foi possível definir três formas possíveis de temporalidade, que serão descritas a seguir: 1) os múltiplos desdobramentos possíveis de uma mesma narrativa; 2) o tempo das inúmeras tentativas de jogo, realizadas por um jogador em busca da vitória; 3) o não conseguir sair do mesmo lugar (que não se dá apenas na sua forma espacial mas que também ocorre, como veremos, em termos temporais). Discutiremos também a existência ou não de traços labirínticos em cada uma dessas formas.

3.3.1 Os múltiplos desdobramentos possíveis de uma mesma narrativa.

Sob este título, está o que Janet Murray classificou como "histórias multiformes": "uma narrativa escrita ou dramatizada que apresenta uma única situação ou enredo em múltiplas versões" (MURRAY, 2003, p. 43). Murray nos dá alguns exemplos de histórias multiformes em textos literários e filmes. Devido à sua forte presença em estudos sobre o assunto, e à associação do seu autor com o tema do labirinto, escolhemos o conto O jardim de veredas que se bifurcam, de Borges (2008a, pp. 80-93), também citado por Murray, como o caso literário de história multiforme a ser estudado neste trabalho.

O narrador do conto, Hsi P’êng, é um espião a serviço do exército alemão, durante a Segunda Guerra Mundial. Com a finalidade de enviar uma informação aos alemães ("o nome do lugar de uma nova base da artilharia britânica"), ele decide matar um habitante da cidade onde se encontra; o sobrenome da vítima é o nome do lugar, Albert. Ao visitá-lo, o espião fica sabendo que Stephen Albert se dedicou ao estudo do livro escrito por um dos seus antepassados, Ts'ui Pên. Este se enclausurou durante treze anos para construir um labirinto e para escrever um labirinto. Quando morreu, apenas o livro foi encontrado. Stephen Albert conta ao espião que finalmente decifrou o livro e as suas contradições ("no terceiro capítulo o herói morre, no capítulo seguinte ele está vivo"). Ele descreve o livro como sendo um "invisível labirinto de tempo" e afirma que o labirinto e o livro elaborados por Ts'ui Pên são "um só objeto”:

Detive-me, como é natural, na frase: "Deixo aos vários futuros (não a todos) meu jardim de veredas que se bifurcam". Compreendi quase imediatamente; "o jardim de veredas que se bifurcam" era o romance caótico; a frase "vários futuros (não a todos)" me sugeriu a imagem da bifurcação no tempo, não no espaço. A releitura geral da obra confirmou essa teoria. Em todas as ficções, cada vez que um homem se defronta com diversas 
alternativas, opta por uma e elimina as demais; na do quase inextricável Ts'ui Pên, opta - simultaneamente - por todas. Cria, assim, diversos futuros, diversos tempos, que também proliferam e se bifurcam. Daí as contradições do romance. Fang, digamos, tem um segredo; um desconhecido chama à sua porta; Fang resolve matá-lo. Naturalmente, há vários desenlaces possíveis: Fang pode matar o intruso, o intruso pode matar Fang, ambos podem se salvar, ambos podem morrer, etc. Na obra de Ts'ui Pên, todos os desenlaces acontecem; cada um é o ponto de partida de outras bifurcações. De vez em quando, as veredas desse labirinto convergem: por exemplo, o senhor chega a esta casa, mas num dos passados possíveis o senhor é meu inimigo, noutro é meu amigo.

(BORGES, 2008a, pp. 89-90)

O tema das histórias multiformes também interessou a diversos cineastas, resultando em alguns filmes que apresentam múltiplos desdobramentos possíveis de uma mesma história. Murray (2003) analisa os casos de De volta para o futuro, Feitiço do Tempo e Rashomon; Egle Spinelli (2005), além de também estudar Rashomon, analisa Corra Lola, Corra e Boca de Ouro; e, por sua vez, Machado (1997a e 1997b) nos traz Smoking / No Smoking. Temos, assim, cerca de uma dezena de filmes onde, de alguma forma, histórias multiformes se fazem presentes.

$\mathrm{Na}$ sua tese de doutorado, Estudos cronotópicos em narrativas audiovisuais, Spinelli analisa três filmes (Rashomon, Corra Lola Corra e Boca de Ouro), utilizando como referenciais teóricos principais a) os estudos de Bakhtin e a sua definição de cronotopo, e b) o trabalho desenvolvido por Barthes sobre os códigos de fragmentação e níveis de sentido. Entretanto, por estarmos olhando para estes filmes a partir dos jogos eletrônicos, nós os classificamos dentro das outras formas de temporalidade que estamos desenvolvendo neste capítulo. Por conta desta classificação, selecionamos, para analisar aqui, o filme Smoking / No Smoking, de Alain Resnais.

Mas a obra até agora mais avançada concebida numa estrutura labiríntica, à maneira da escritura paradoxal de Ts'ui Pen, não pode ser enquadrada como hipermídia e nem mesmo foi realizada com recursos da informática: trata-se do filme (na verdade dois filmes) de Alain Resnais, Smoking/No Smoking (1994), narrativa permutativa e combinatória que se multiplica em 24 possibilidades de ocorrência, com base em uma situação simples inicial. Celia Teasdale, após fazer a limpeza da casa, sai para tomar um ar no jardim. Fumará ou não fumará? Se fumar, as coisas correrão de uma maneira; se não fumar, as coisas correrão de outra. Ao longo de todo o filme, as situações se bifurcam, as ações retrocedem para um novo recomeço e a narrativa, em vez de progredir, vai se multiplicando em novas e mais novas possibilidades de resolução das mesmas situações. Assim, com base em uma situação dada, que comporta seis personagens principais, diversas combinações narrativas vão sendo experimentadas, fazendo com que a história evolua no sentido horizontal, no sentido da multiplicação das possibilidades de ocorrência da mesma situação, em vez de na direção de um fio narrativo linear. O mais interessante nesse(s) filme(s) é que nele(s) o caráter dos personagens jamais pode ser fixado: em cada bifurcação, em cada possibilidade, os mesmos personagens são tipos distintos, com diferentes características psicológicas e diferentes motivações uns em relação aos outros, tornando praticamente impossível enquadrá-los em modelos monológicos. $\mathrm{O}(\mathrm{s})$ filme(s) de Alain Resnais aparece $(\mathrm{m})$ assim como uma das obras mais bem-sucedidas na representação da complexidade da vida. (MACHADO, 1997a, p. 259) 
Após vermos os dois filmes que compõem esta obra de Resnais, é muito difícil ter uma visão exata de todas as possibilidades apresentadas por ela. É como se o cineasta conseguisse nos fazer ver a própria multiplicidade das possibilidades, mais do que um conjunto finito das mesmas. Seguindo o raciocínio de Machado, consideramos que Smoking / No Smoking é o que mais se aproxima de O jardim de veredas que se bifurcam, entre o conjunto de filmes analisado neste capítulo - apesar destes serem associados, pelos autores já citados, com a noção de história multiforme - pelos seguintes motivos:

- $\quad$ o que é destacado pelos autores (Resnais e Borges) é a própria multiplicidade de possibilidades; ela é exposta de maneira que a atenção do leitor/espectador seja atraída para a mesma. Já nos outros filmes, há elementos tão ou mais importantes que essa multiplicidade;

- no caso dos filmes Corra, Lola, Corra e O Feitiço do Tempo, consideramos que a multiplicidade de narrativas está subordinada a outras formas de temporalidade. No caso de Corra, Lola, Corra, a forma principal é a do jogador que joga o mesmo jogo até vencê-lo; já em O Feitiço do Tempo, temos uma combinação das três formas, com ênfase para o não conseguir sair do mesmo lugar. Ambos os filmes serão analisados com mais detalhes a seguir;

- $\quad$ já nos casos de Rashomon e Boca de Ouro, de acordo com a análise feita por Spinelli, a multiplicação da narrativa em diversas possibilidades dá-se por uma variação do ponto de vista; cada novo ponto de vista gera uma versão diferente para a mesma narrativa. Em Rashomon, Akira Kurosawa obtém um ponto de vista para cada personagem que narra os mesmos fatos; já em Boca de Ouro, temos um ponto de vista que varia em função da flutuação dos sentimentos da personagem que narra o filme, Guigui, em relação ao personagem Boca de Ouro. Devido à importância que o conceito de ponto de vista tem para este trabalho, consideramos estes dois filmes como casos de uma multiplicidade que é espacial e temporal.

Em relação à presença de "labirintos de caminhos que se bifurcam" nos jogos eletrônicos, encontramos razões para afirmar que eles estão presentes em todos os jogos, não apenas nos eletrônicos. Afinal, todos os jogadores precisam, a todo momento, analisar a partida e refletir sobre quais são as melhores jogadas e as melhores ações a executar. O que os jogos eletrônicos trazem 
de novo é a facilidade de voltar atrás e continuar uma partida a partir de um ponto anterior, a fim de tentar alternativas. Dizemos que é a facilidade de voltar atrás, e não a possibilidade, porque os adeptos de alguns jogos tradicionais praticam, há muito tempo, o exercício de retomar uma partida a partir de um ponto anterior. Colocamos, como exemplo, o jogo de xadrez ${ }^{106}$ : é possível encontrar livros de partidas, assim como sites com partidas completas, e reconstituí-las com o uso de um tabuleiro. Desta forma, um enxadrista pode testar variações, verificar qual a melhor forma de se defender de um ataque do adversário; pode refazer uma partida que perdeu e procurar quais foram as jogadas que causaram a sua derrota.

3.3.2 O tempo das inúmeras tentativas de jogo

Apesar do primeiro jogo eletrônico, Spacewar, ter sido desenvolvido num computador por Steve Russel em 1962 $2^{107}$, foi nos arcades que os jogos eletrônicos se disseminaram ao longo da década de 70. Para jogar numa máquina do tipo arcade, o jogador comprava uma ficha para ter direito a uma partida. Isto afetou diretamente o desenvolvimento dos jogos arcade pois estes não poderiam tomar muito tempo do jogador, o que reduziria o lucro dos donos das cabines. Assim,

(...) jogos do tipo arcade, em que os jogadores pagam por cada rodada separadamente, tendem a ser jogos de curta duração, normalmente acabando em alguns minutos, permitindo mais rodadas e, portanto, um lucro maior. Os melhores jogadores são aqueles que permanecem mais tempo nas máquinas e os que obtêm mais tempo de jogo pelo seu dinheiro; entretanto, tornar-se bom jogador requer prática e muitas rodadas de jogo (e, portanto, fichas compradas). Por sua vez, videogames domésticos e jogos de computador, que são comprados ao invés de serem "alugados" por rodada de jogo, podem se dar ao luxo de terem jogos baseados na solução de desafios e outros gêneros que requerem várias horas de ação, assim como jogos de natureza mais envolvente e contemplativa. Não é à toa que "adventures" baseados em texto e jogos como Myst nunca foram lançados para cabines. (WOLF, 2002, p. 87, tradução nossa ${ }^{108}$ )

106 Realizaremos mais comentários sobre o jogo de xadrez no capítulo dedicado ao trabalho O tabuleiro dos jogos que se bifurcam, a partir página 123 .

107 Alguns autores consideram que um experimento do físico Willy Higinbotham, desenvolvido em 1958, pode ser considerado como um jogo eletrônico, tendo sido, assim, o primeiro jogo eletrônico da história (KENT, 2002, p. 18). Entretanto, ao contrário de Spacewars, ele não foi distribuído nem licenciado para produção industrial, o que impediu a sua popularização.

108 Texto original em inglês: (...) arcade games, in which players pay for each game play individually, tend to have games with very fast action that are tipically over in a few minutes, allowing for more play and thus more income. The better players are, the longer they last, and the more value they get for their money; however, getting better may require practice and many games (and many quarters) to begin with. In contrast, home games systems and computer games, which are purchased rather than paid for game by game, can afford to have slower puzzle-based or adventure games lasting hours on end, and games more involving and contemplative in nature. It is no surprise that text adventures and games like Myst never appeared in the arcade. 
Quando, a partir dos anos 70, a Atari e outras empresas lançaram os primeiros videogames domésticos, os jogos começaram a sofrer alterações importantes. Wolf (2002, p. 87) aponta que a possibilidade de salvar um jogo, bem como o fato do consumidor pagar pelo jogo, e não pelas partidas, fez com que os novos jogos eletrônicos se tornassem mais complexos, exigindo diversas sessões de jogo para serem completados. Ao longo dessas sessões, o jogador precisa ampliar o seu conhecimento das regras e do funcionamento do jogo, assim como dos seus cenários, para que ele possa avançar no jogo.

É na repetição de um mesmo jogo, seja a partir do início, seja a partir do ponto em que o jogo foi salvo, que encontramos uma forma de temporalidade que é uma característica importante dos jogos, não apenas dos jogos eletrônicos. Baseando-nos na análise realizada por Spinelli (2005), gostaríamos de apresentar o filme Corra Lola, Corra como uma manifestação exemplar desta forma de experimentar o tempo, em que o jogador joga o mesmo jogo até alcançar os seus objetivos.

O filme Corra Lola, Corra (...) mostra três possibilidades de enredo geradas a partir de um mesmo núcleo inicial. O filme começa com a representação deste início em comum que fornece informações a respeito dos personagens principais, Lola e o namorado Manni, e já estabelece os seus objetivos fundamentais da história. Manni esquece uma sacola com cem mil marcos dentro do metrô referente a uma transação de drogas que tinha acabado de fazer. Por telefone, avisa Lola que se em vinte minutos não entregar o dinheiro ao seu chefe, vai assaltar o supermercado localizado na frente da cabine telefônica para tentar conseguir o dinheiro. Caso contrário não teria escapatória e seria morto pelo chefe. Lola pede que ele a espere e não faça nada, pois em vinte minutos conseguirá o dinheiro para o namorado. A partir daí, são mostradas três histórias diferentes organizadas uma após a outra. Quando uma acaba, outra começa do mesmo ponto em que se iniciou a anterior.

(SPINELLI, 2005, p. 134. Grifo em negrito nosso)

As três possibilidades de enredo, citadas por Spinelli, consistem nas três tentativas, executadas por Lola, de obter o dinheiro necessário para salvar seu namorado. Spinelli desenvolve diversas relações entre o filme e o universo dos jogos eletrônicos, o que nos permite ver Lola como uma jogadora. Primeiro, em termos visuais: “(...) Lola parece um herói de videogame, com suas tatuagens e cabelos vermelhos, o mesmo figurino em todo o filme e um certo poder de comando da história narrada." (SPINELLI, 2005, p. 153). A segunda relação apontada por Spinelli é a que justifica a inclusão de Corra Lola, Corra nesta pesquisa: a realização de diversas "tentativas rumo à realização do objetivo final" (SPINELLI, 2005, p. 154), com o desenvolvimento de um aprendizado a partir das experiências anteriores: 
O filme apresenta três versões distintas que fazem uma alusão ao jogar três vezes o mesmo jogo. A cada nova partida a personagem-jogadora Lola enfrenta obstáculos e adquire experiências para seguir adiante e atingir o seu objetivo. Qualquer incidente, como um tropeço, uma colisão ou um desencontro, podem alterar o futuro de todos os personagens que cruzam o caminho de Lola. E esta parece ser a idéia central do filme: a mudança de um detalhe mínimo pode ser responsável por uma alteração em todos o destino da história. Cada versão se diferencia por acasos diferentes que conduzem às mudanças de conduta de Lola e demonstram como pequenas coincidências ou grandes tragédias podem influenciar no futuro particular de cada um.

(SPINELLI, 2005, p. 154. Grifos em negrito são nossos)

Este último trecho da análise de Spinelli, junto com as observações de Murray ${ }^{109}$ sobre o “jogar novamente" $" 110$, nos ajudam a observar que esta temporalidade não está isolada do jardim de veredas que se bifurcam. A seqüência de tentativas nos leva a perceber outros modos possíveis de atuar no jogo, distinguindo diversas possibilidades que o mesmo jogo contém. Entretanto, assim como ocorre em Corra Lola, Corra, a multiplicidade não é o centro da atenção do jogador: este continua preocupado, antes de mais nada, com a vitória. Assim, o jogador olha para o labirinto de veredas que se bifurcam para ver qual deles o conduzirá à vitória. Neste ponto reside, para nós, uma diferença importante entre Corra Lola, Corra, e Smoking/No Smoking: no primeiro, três desenvolvimentos da mesma história são suficientes, pois ela consegue vencer no terceiro; já no segundo, a multiplicidade é o mais importante. Se Tom Tykwer privilegia o ponto de vista do jogador, Resnais privilegia os pontos de vista de Ts'ui Pên (que observa o mesmo labirinto para apreciar a multiplicidade de caminhos).

No filme, há um conjunto de seqüências que opera uma passagem, temporária, da preocupação com a vitória para a contemplação das diversas possibilidades de desenvolvimento de uma narrativa, causadas pela "mudança de um detalhe mínimo". São as seqüências de fotografias que resumem o destino de diversos personagens com os quais Lola cruza no seu percurso, destino este que é diferente em cada uma das três tentativas (possibilidades de enredo). Porém, assim que cada

109 MURRAY, Janet. From Game-Story to Cyberdrama. In: WARDRIP-FRUIN, Noah; HARRIGAN, Pat (ed.). First-Person. New Media as Story, Performance, and Game. Cambridge, Massachussets - London: The MIT Press, 2004. pp. 2-11.

110 O jogar novamente é um dos aspectos da atividade lúdica, uma das estruturas mais prazerosas e características dos jogos de computador em particular, que é geralmente viabilizado pela possibilidade de salvar o jogo a intervalos regulares (...). Num jogo, o objetivo pode ser dominar o roteiro, de modo a executar as ações corretas na ordem certa. (...) Mas isso também pode refletir a nossa consciência das múltiplas possibilidades de um momento, o momento pululante, como Borges o chamou (...). Um mundo de histórias que podem ser jogadas novamente permite ao interator vivenciar todas as possibilidades de um momento, sem privilegiar nenhuma delas como sendo a escolhida. (MURRAY, 2004, pp. 6-7. Tradução nossa) 
seqüência de fotografias termina de ser exibida, o espectador volta para a corrida de Lola e a perseguição dos seus objetivos.

Podemos encontrar passagens parecidas nos jogos, que ocorrem quando o jogador deixa de lado, por alguns instantes, a busca da vitória e torna-se mais especulativo: "o que acontecerá se eu fizer tal coisa?". É como se a perseguição dos objetivos fosse interrompida por um "Ou então", frase que caracteriza a exibição de uma nova alternativa para o destino dos personagens de Smoking / No Smoking. Tais passagens se dão no já citado exemplo das horas de estudo de um enxadrista, em que ele pode analisar uma partida de forma mais especulativa do que quando está jogando contra um adversário.

Para finalizar, devemos observar que o ato de continuar tentando obter sucesso num jogo, ao longo de diversas sessões de jogo, possui poucas características labirínticas. Entretanto, ele pode ajudar o jogador a perceber o jardim de veredas que se bifurcam presente em cada jogo. Isto é, perceber que a diversidade de ações possíveis faz com que as possibilidades de desenvolvimento do jogo sejam inúmeras. Por outro lado, as tentativas podem degenerar para uma situação em que o jogador fica "preso", sem conseguir avançar. Aqui, teríamos uma situação que remete ao momento em que alguém, no interior de um labirinto, se desloca sem dar meia-volta e, mesmo assim, volta a um lugar pelo qual já passou. É a situação que estudaremos a seguir.

\subsubsection{O não conseguir sair do mesmo momento / lugar}

No filme O Feitiço do Tempo, Bill Murray vive Phil Connors, meteorologista e apresentador de TV. Ao visitar uma cidade do interior, ele é surpreendido por uma tempestade (sua previsão do tempo estava errada), de modo que precisa voltar para o hotel. Seu drama começa quando Phil acorda: o rádio transmite as mesmas notícias e as pessoas no hotel repetem os mesmos atos do dia anterior. Após uma certa perplexidade, ele percebe que "acordou" no dia anterior. E isso se repete por dias a fio, provocando diferentes atitudes por parte de Phil.

As diferentes formas com que Phil encara a sua condição, assim como alguns comentários sobre o filme - (MURRAY, 2003, p. 48) e (NEITZEL, 2006, p. 236) 111 - nos permitem perceber 
manifestações das três formas temporais discutidas neste capítulo:

- Inicialmente, o humor do filme é baseado na perplexidade de Phil. Depois, ele começa a aproveitar todo o conhecimento que consegue reunir sobre os acontecimentos do dia mas, em seguida, ele se deixa tomar pelo desespero. Phil chega a tentar o suicídio diversas vezes, sem sucesso: mesmo após se matar, ele sempre acorda no dia 2 de fevereiro. Como são inúmeras as vezes em que ele acorda nesse dia (uma comparação: Lola só precisa de três tentativas para alcançar seus objetivos), vemos aqui um caso similar ao do jogador que, apesar de todos os seus esforços, não consegue avançar num jogo: ele sempre morre lutando contra o mesmo inimigo, ou é parado por um enigma que não consegue solucionar;

- se observarmos as tentativas, por parte de Phil, de seduzir a sua colega Rita, veremos um caso de jogador que repete o mesmo jogo até alcançar os seus objetivos. Entretanto, o seu progresso é muito mais lento que o de Lola:

O prazer da audiência está em saborear as variações, imaginando o que Phil fará na próxima vez. (...) Quando decide seduzir sua produtora, Rita, ele repete seu encontro com ela interminavelmente, revisando cada aspecto para ajustar-se às preferências e fantasias dela, apenas para terminar recebendo um tapa na cara e rejeitado várias vezes consecutivas. Até que Phil aprende a viver seu único dia como uma pessoa melhor: ele estuda piano, evita os acidentes que sabe que irão acontecer e abre seu coração para as pessoas que antes desprezava. Assim que ele consegue fazer tudo certo, conquista o amor de Rita e, finalmente, acorda no dia 3 de fevereiro.

(MURRAY, 2003, p. 48)

- finalmente, como observa Murray, o filme apresenta as infinitas possibilidades de vivenciar o mesmo dia. Assim, também temos uma manifestação do labirinto, temporal, dos caminhos que se bifurcam.

Escolhemos este filme como caso exemplar para a situação de não conseguir avançar num jogo por entendermos que esta é a situação predominante do filme. Todo o seu enredo, e inclusive as manifestações das outras formas temporais, deriva do fato de que Phil está preso no mesmo dia. E ele também consegue ilustrar, muito bem, as atitudes de um jogador que fica "preso" num jogo: deixar-se vencer pela frustração e abandonar o jogo (tentativas de suicídio); repetir, meticulosamente, tudo o que deu certo até o ponto em que o jogo foi perdido e só aí tentar uma ação diferente (seqüências em que ele tenta seduzir Rita); e, finalmente, tentar uma reformulação geral de seu modo de agir (como coloca Murray na citação anterior). 
Há outra possibilidade para um jogador não conseguir avançar num jogo, que é a indecibilidade, tal como definida por Aleph Einchemberg na sua dissertação de mestrado, $A$ experiência do tempo morto no cinema e nos "games" (2005):

Certos games têm tamanho poder de agenciamento que suas múltiplas possibilidades de escolha causam em nós uma certa indecibilidade, uma impossibilidade de decidir qual ação é a melhor, a mais adequada. Em Black and White (2001), por exemplo, não sabemos se em determinado momento do jogo procuramos por objetos sagrados, se a aldeia está superlotada, se tem algum pescador que está se afogando, se construímos um barco, se soltamos nossa criatura, se a aldeia precisa de comida, se castigamos o povoado por perderem a fé, etc. São muitas decisões que surgem e que vão se acumulando e dissolvendo, conforme o desenrolar do jogo, e, apesar de se esforçar ao máximo, o interator sabe que poderia ter feito mais e que muita coisa vai escapar do alcance de sua visão.

(EINCHEMBERG, 2005, pp. 48-9)

Se os sucessivos fracassos em avançar num jogo remetem à situação em que alguém, que esteja dentro de um labirinto, retorna a um ponto previamente visitado, sem nunca ter dado meiavolta, a indecibilidade remete à indecisão frente a uma encruzilhada ou a uma bifurcação. Para lidar com tal situação, foram criados diversos métodos para se percorrer um labirinto, tal como descritos por Rosensthiel (1988b) e Stewart (2008). Já no caso dos jogos eletrônicos, consideramos, a partir da nossa experiência pessoal como jogador, que a grande maioria dos jogadores enfrenta a indecibilidade com o método de tentativa e erro, num primeiro momento, e com a criação de estratégias próprias, a partir dos resultados alcançados. Porém, devemos observar que um grau muito alto de indecibilidade diminui o agenciamento do jogador, de acordo com a definição de Murray (2003, p. 127). A autora coloca o agenciamento como algo que ocorre em função das nossas ações num ambiente eletrônico e das respostas deste ambiente:

Quanto mais bem resolvido o ambiente de imersão, mais ativos desejamos ser dentro dele. Quando as coisas que fazemos trazem resultados tangíveis, experimentamos o segundo prazer característico dos ambientes eletrônicos - o sentido de agência. Agência é a capacidade gratificante de realizar ações significativas e ver os resultados de nossas decisões e escolhas. Esperamos sentir agência no computador quando damos um duplo clique sobre um arquivo e ele se abre diante de nós, ou quando inserimos números numa planilha eletrônica e observamos os totais sendo reajustados. (...)

(MURRAY, 2003, p. 127)

Assim, a indecibilidade deve ocorrer como um desafio, como um catalisador para a elaboração de estratégias por parte do jogador. Se este apela para a mera tentativa e erro, significa que há uma escassez de informações, insuficientes para que o jogador tenha uma idéia do que fazer. É 
como se, de certa forma, o jogo falhasse no seu convite à exploração ${ }^{112}$ e o labirinto se dissolvesse num amontoado de elementos sem sentido. Isto também explica o alto grau de agenciamento experimentado por jogadores de um jogo como Myst. por mais difícil que ele possa ser, é a certeza de que há algum nexo oculto que inspira o jogador a continuar explorando o mundo do jogo e a elaborar conexões entre os elementos que obtém ao longo do seu percurso.

112 Jogos como Myst e Doom, tal como analisados por Manovich (2002, pp. 244-285), realizam um convite à exploração espacial, assim como o labirinto (MACHADO, 1997b, pp. 254-5) e (ROSENSTHIEL, 1988, p. 252). 


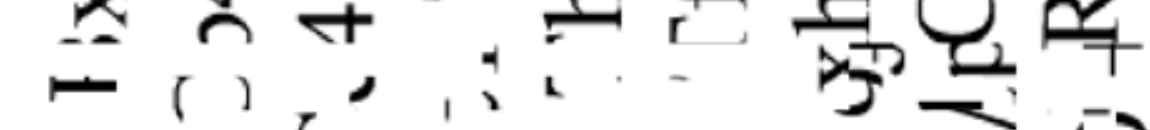

פ

य -

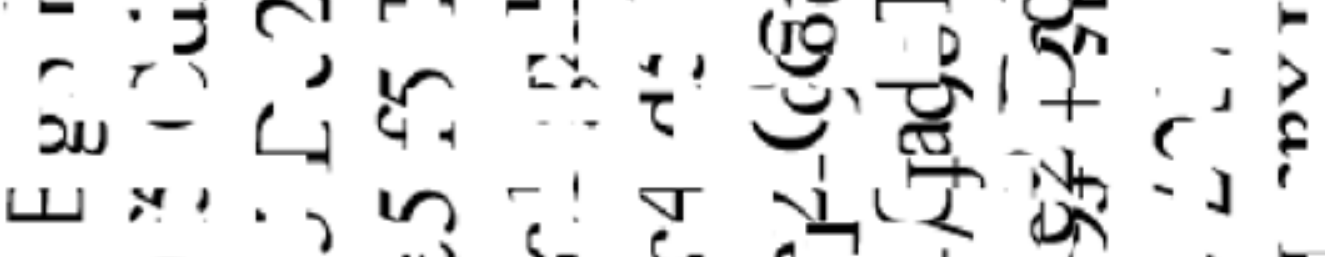

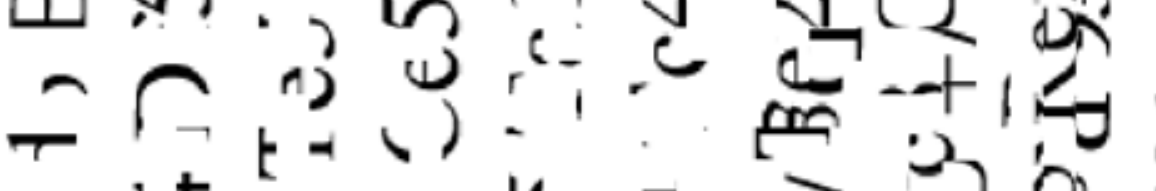

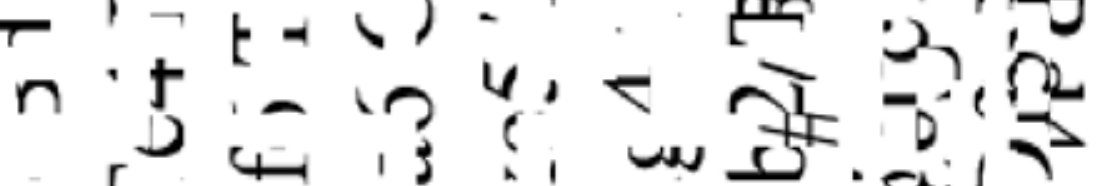

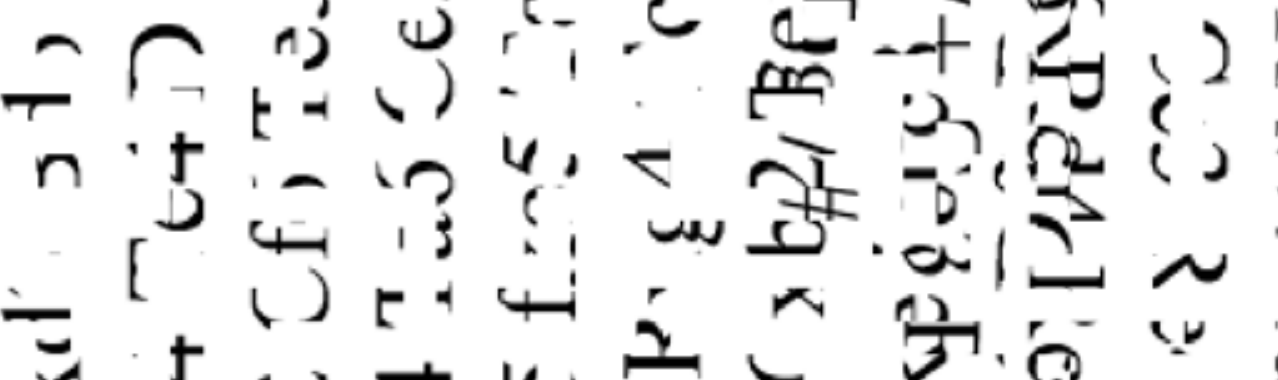

4. 7 ?

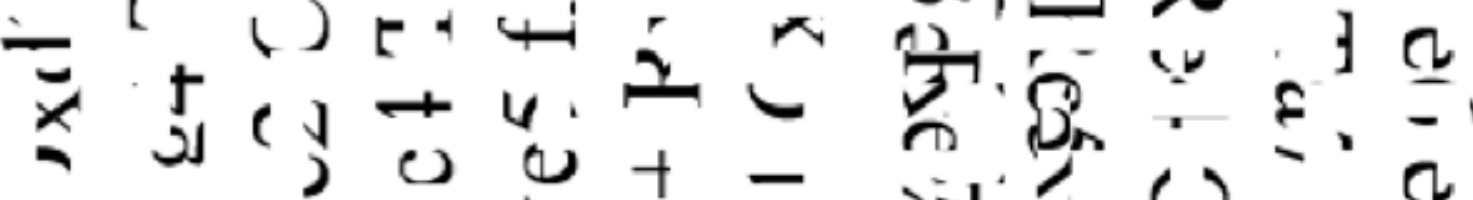

m\&dis:

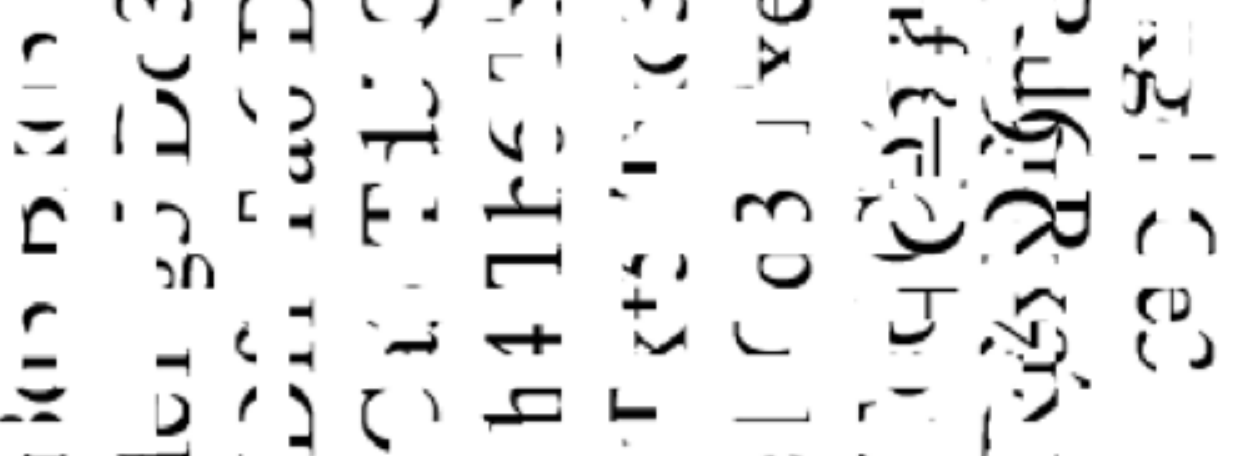

$=1$

.

N ט

כ

J向 $\Pi 12$

- $\cos ;$

-

-

$=-N$

$\therefore-10$ ×

$\therefore T$ T 2

-1

a

- 1

(a)

a

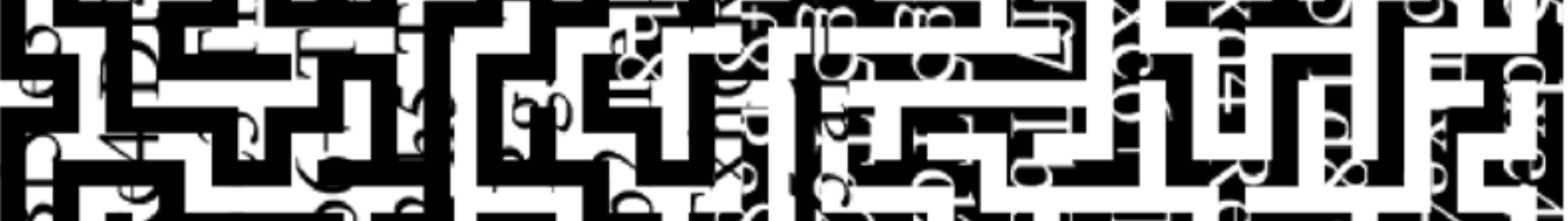

$6 x^{2}=$

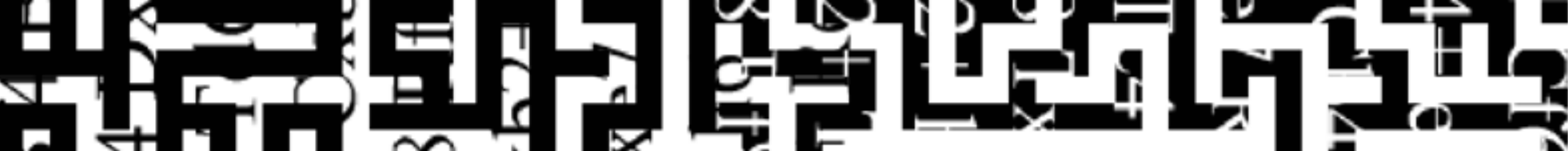

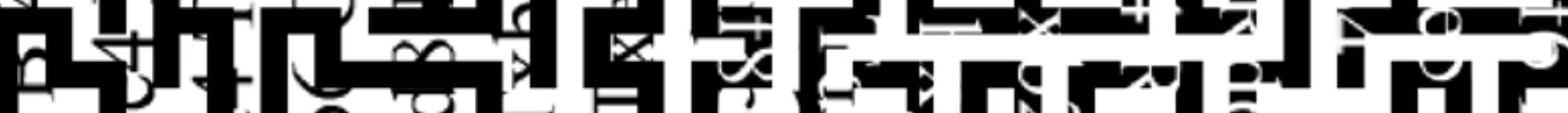

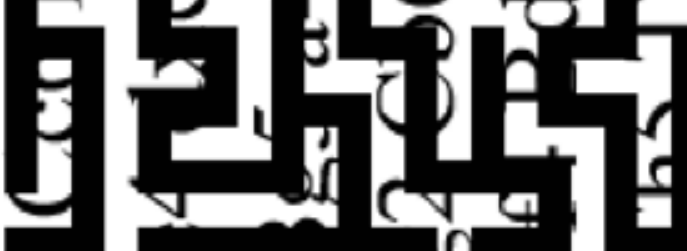

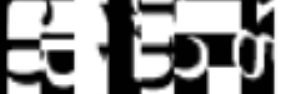
$4 \%$ o 0

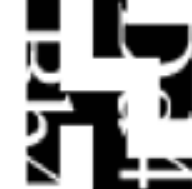

mand

a.

xing

I.1

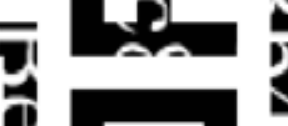

$2=$

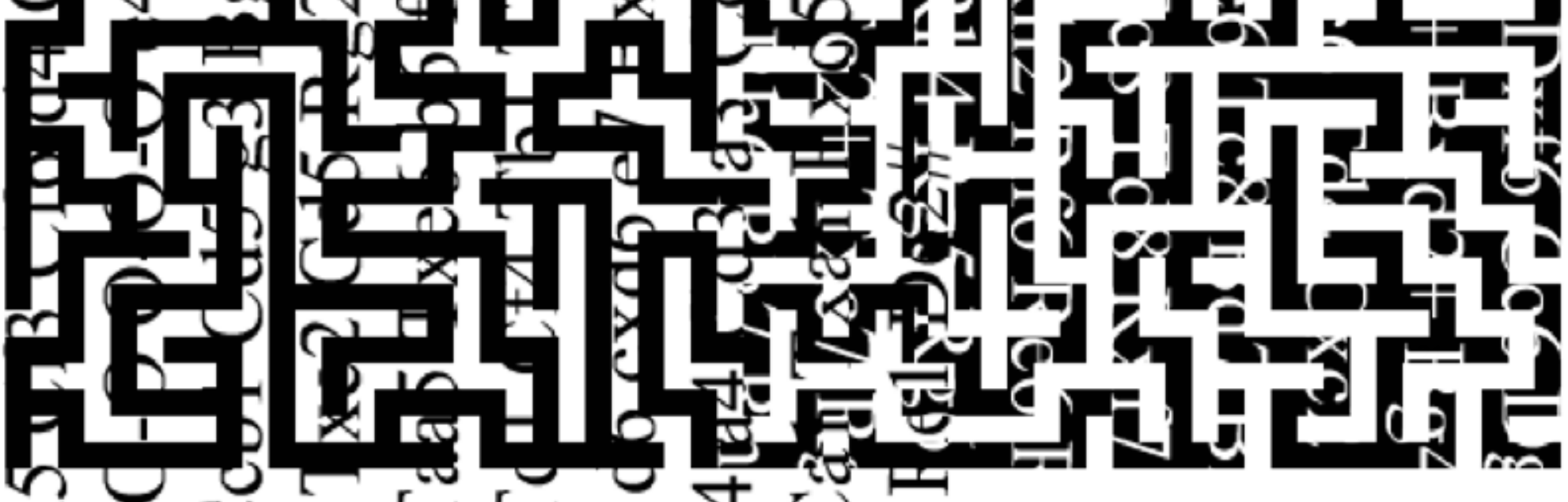





\title{
E O tabuleiro dos jogos que se bifurcam
}

Este trabalho é o resultado da nossa intenção de relacionar o conto O jardim de veredas que se bifurcam, de Borges (2008a, pp. 80-93), com algumas observações de Marcel Duchamp sobre o jogo de xadrez (CABANNE, 2002, p. 28) e com o funcionamento dos jogos computadorizados de xadrez, tais como o GNU-Chess ${ }^{113}$. Tal associação terá por base o labirinto criado por Borges neste conto, do qual identificamos traços tanto no discurso de Duchamp quanto nos jogos de xadrez.

Não retomaremos o conto borgiano neste momento, por já o termos citado no texto anterior. Por isso, vamos trazer um trecho das entrevistas de Marcel Duchamp feitas por Pierre Cabanne, no livro Marcel Duchamp: Engenheiro do Tempo Perdido, em que ele afirma:

\begin{abstract}
Uma partida de xadrez é uma coisa visual e plástica, e se não é geométrica no sentido estático da palavra, é mecânica, desde que se move; é um desenho, é uma realidade mecânica. As peças não são belas por elas mesmas, assim como a forma do fogo, mas o que é belo - se a palavra "belo" pode ser usada - é o movimento. Então, é uma mecânica, no sentido, por exemplo, de um Calder. No xadrez, existem, sem dúvida, coisas extremamente belas no domínio do movimento, mas não no domínio visual. Imaginar o movimento ou o gesto é que faz a beleza neste caso. Está completamente dentro da massa cinzenta. (CABANNE, 2002, p. 28. Grifo nosso)
\end{abstract}

A relação que pretendemos propor com $O$ tabuleiro dos jogos que se bifurcam é a proximidade entre o ato de "imaginar o movimento ou o gesto", executado pelo jogador de xadrez, e o ato de imaginar os diversos desenlaces possíveis de cada ponto de uma narrativa, realizado por Ts'ui Pên ${ }^{114}$. Enxergamos uma semelhança entre os dois raciocínios: em ambos precisamos imaginar os diversos desdobramentos possíveis a partir de um determinado momento (configuração do tabuleiro ou da narrativa).

Esta proposição ganha força na medida em que encontramos, nos jogos computadorizados de xadrez, um procedimento semelhante. Os jogos de xadrez calculam quais são as jogadas possíveis a partir de um determinado momento e avaliam, através de um sistema de pontuação ${ }^{115}$, quais as jogadas mais vantajosas. O que irá determinar a dificuldade de um jogo de xadrez para computador são características como: a) quantas jogadas à frente o software irá calcular antes de realizar o seu

113 Jogo de xadrez open source, disponível para download no site http://www.gnu.org/software/chess/.

114 O antepassado do narrador de O jardim de veredas que se bifurcam.

115 Por exemplo, um jogo (software) de xadrez considera que um Peão na sétima casa, prestes a ser promovido, vale muito mais do que um Peão na sua casa inicial; uma Torre que limite os movimentos do Rei adversário vale mais do que uma Torre que esteja sem liberdade de movimentação; e assim por diante. 
lance e b) a qualidade do sistema de pontuação utilizado para avaliar as jogadas possíveis. Diversos jogos permitem ao jogador ver quais os lances que o software está analisando, e quais desdobramentos ele considera mais prováveis.

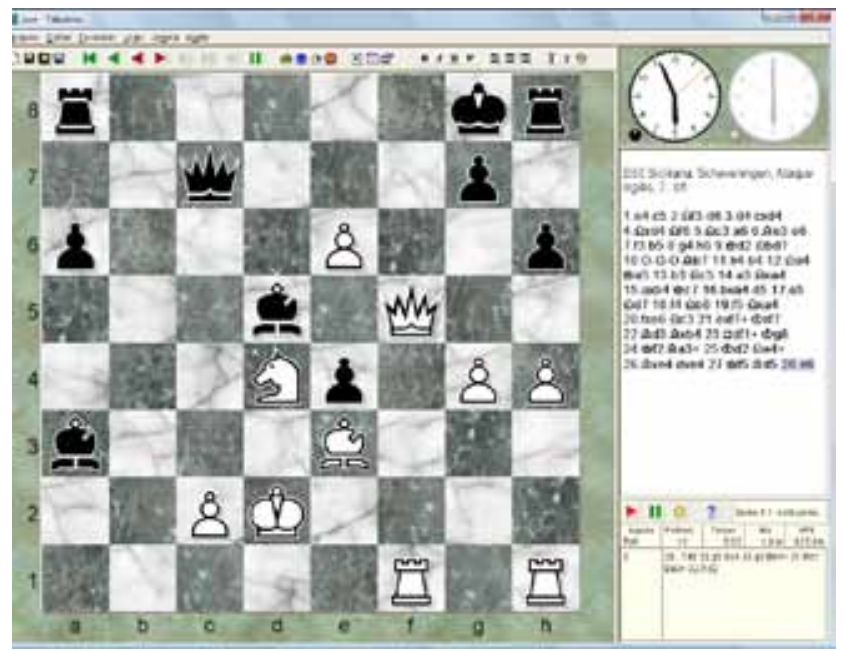

\begin{tabular}{|l|c|c|c|c|}
\hline Jogada & Profund... & Tempo & Nós & NPS \\
Td8 & 13 & $0: 02$ & $1,9 \mathrm{M}$ & $925,9 \mathrm{k}$ \\
\hline 0 & $28 .$. Td8 $29.95 \mathrm{Bc4}$ & $30.96 \mathrm{Bb} 4+31 . \mathrm{Rc1}$ \\
& Ba3+32.Rd2 & \\
& & & \\
& & & \\
& & & \\
\end{tabular}

Ilustração 56. Tela de um jogo de xadrez com os "pensamentos" do jogo116

Uma outra forma de visualizar os cálculos feitos por um jogo de xadrez é proposta pela série de trabalhos Thinking Machine ${ }^{117}$, de Marek Walczak e Martin Wattenberg. No lugar das letras e números exibidos pela interface dos jogos, Thinking Machine utiliza linhas curvas para representar o "pensamento" de um jogo de xadrez:

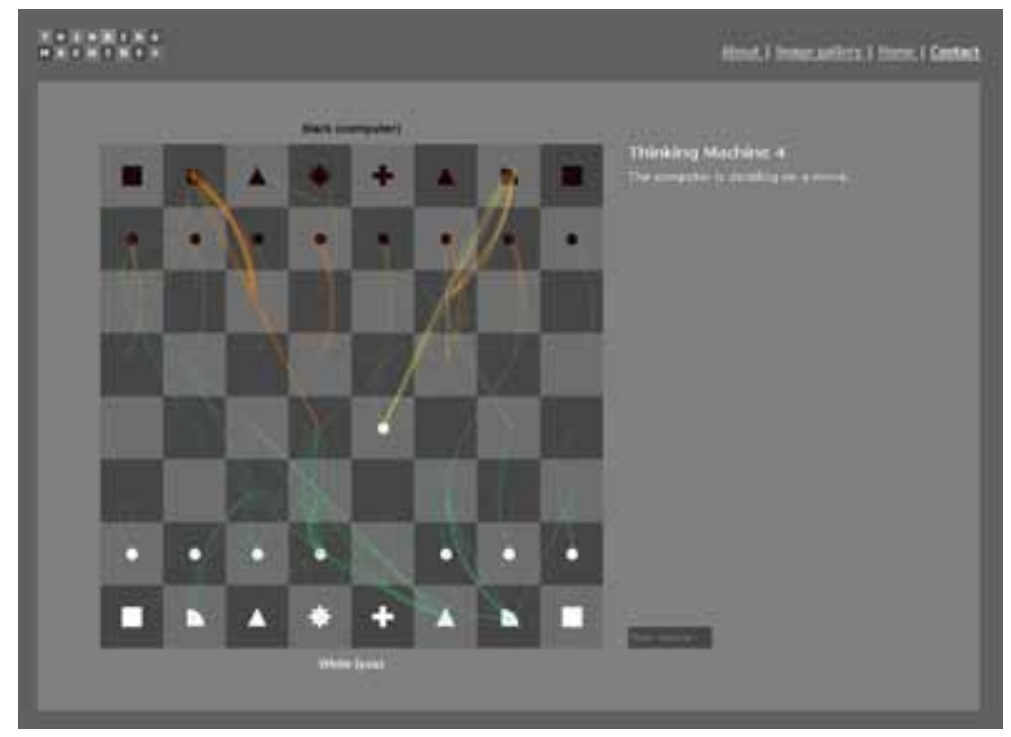

Ilustração 57. Thinking Machine 4, instantes após movermos o peão do rei. Alguns movimentos possíveis já são representados na tela.

116 Imagem do software Jose Chess, distribuído como open source no site http://jose-chess.sourceforge.net. http://mw2mw.com/thinking-table/ 


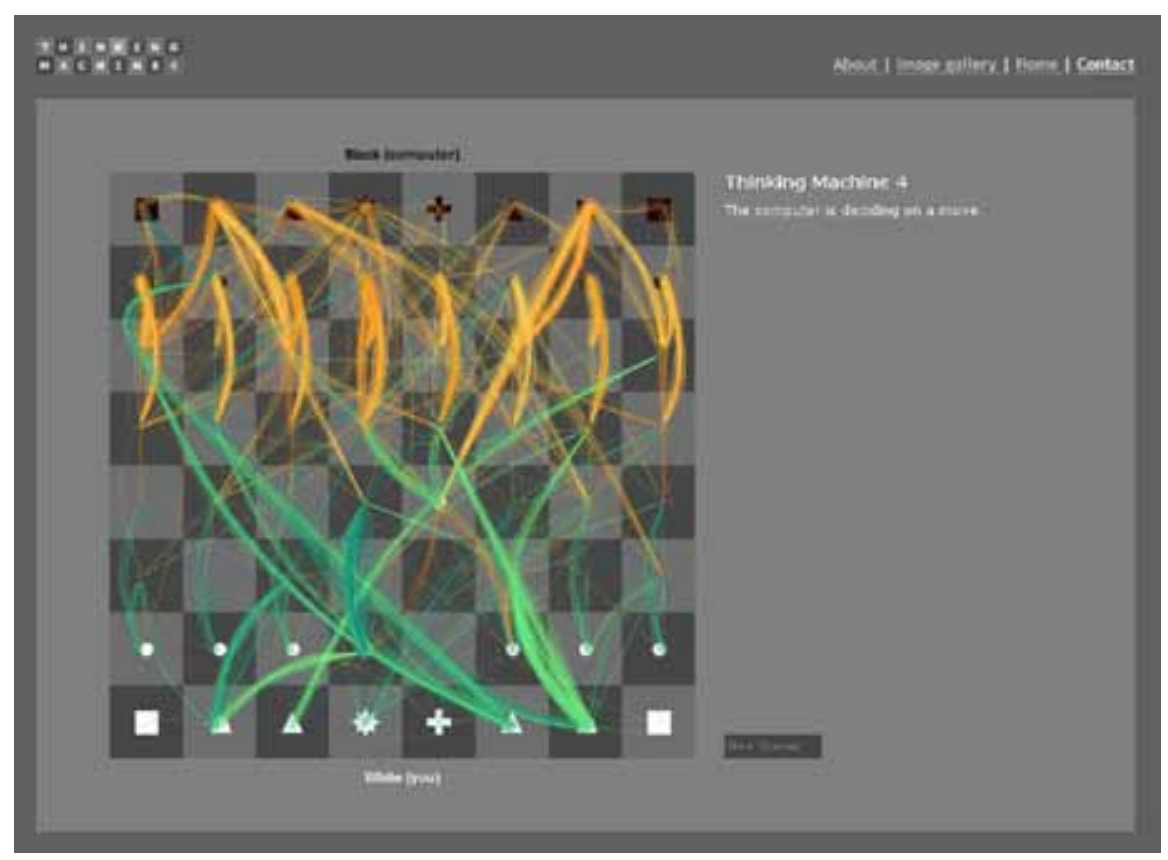

Ilustração 58. Thinking Machine 4, prestes a jogar após o nosso movimento do peão do rei. Podemos observar que a quantidade de movimentos representados cresceu de forma expressiva, num tempo de aproximadamente um minuto.

Apesar da forte beleza de Thinking Machine 4, um conjunto de fatores nos fez levar adiante o projeto de $O$ tabuleiro dos jogos que se bifurcam, e correr o risco de realizar um trabalho muito próximo da obra de Walczak e Wattenberg. O primeiro, e mais importante, era o nosso interesse em apontar, de forma bastante direta, a semelhança entre o labirinto temporal criado por Borges e o processo de pensamento do jogador de xadrez, tal como descrito por Duchamp, e de cálculo feito pelos softwares enxadristas, como desenvolvido por Thinking Machine 4. O segundo fator foi a inteção de usar a notação das partidas de xadrez, onde os movimentos da partida são descritos por uma combinação de letras e números, ao invés de uma representação visual mais explícita, tal como ocorre em Thinking Machine. Essa intenção decorre da experiência que nos fez estabelecer as relações que estão na base deste trabalho: ao jogar xadrez contra o computador, e observar os seus cálculos - que eram exibidos usando a notação composta por letras e números - enquanto aguardávamos a sua jogada, sentíamos o desejo de isolar visualmente a janela onde eles eram apresentados, escondendo o tabuleiro e o restante da interface do jogo, para sermos fruidores deste processo.

Assim, para a realização de $O$ tabuleiro dos jogos que se bifurcam, também optamos por tornar visíveis os cálculos realizados por um jogo computadorizado de xadrez, utilizando uma das formas de anotar uma partida de xadrez. Apesar deste cálculo já ser exibido em diversos jogos de xadrez, 
consideramos que era necessário isolá-lo e recontextualizá-lo ${ }^{118}$ : ao invés de termos uma ferramenta que auxilia o jogador (caso do cálculo, quando exibido dentro de um jogo de xadrez), pretendemos tornar o processo de "imaginação", no caso do jogador humano, e de "cálculo", no caso do jogo computadorizado, passível de fruição estética, relacionando-o com o texto literário e com o jogo que, possivelmente, serão conhecidos pelo espectador do trabalho ${ }^{119}$.

Inicialmente, pesquisamos diferentes formas de representação visual do jogo de xadrez (desde simulações tridimensionais do tabuleiro até os gráficos utilizados na literatura especializada), e as diferentes formas de anotar uma partida. Existem diversas notações para o jogo de xadrez; entre as mais conhecidas estão o Sistema Descritivo e o Sistema Algébrico (D’AGOSTINI, 2002, p. 40); ambas combinam letras e números para indicar as peças movidas e as casas ocupadas por estas. Além destas duas notações, no universo dos jogos computadorizados de xadrez, também encontramos uma outra forma de notação, que consiste em simplesmente utilizar as casas de origem e destino da peça movida, sem nenhuma referência ao tipo de peça que foi movida. Exemplos:

\section{Sistema Descritivo}

T4TR - Torre na quarta casa da coluna da Torre do Rei

Sistema Algébrico

Th1-h4 - Torre que estava na coluna h, linha 1, é movida para a coluna h, linha 4

Sistema Algébrico Abreviado

Th4 - Torre na coluna h, linha 4

118 Apesar do uso do verbo "recontextualizar" poder ser visto como uma referência ao procedimento de Duchamp ao criar os ready-mades, é preciso apontar uma diferença crucial: Duchamp opta por objetos que lhe causam indiferença; já no nosso caso, o processo que estamos recontextualizando nos concerne em diversos aspectos, provocando um profundo interesse de nossa parte. Sobre os ready-mades e a busca da indiferença, Duchamp é explícito:

P: O que determinava a escolha dos ready-mades?

R: Isto dependia do objeto; em geral, era preciso tomar cuidado com o seu look. É muito difícil escolher um objeto porque depois de quinze dias você começa a gostar dele ou a detestá-lo. É preciso chegar a qualquer coisa com uma indiferença tal, que você não tenha nenhuma emoção estética. A escolha do ready-made é sempre baseada na indiferença visual, e ao mesmo tempo, numa ausência total de bom ou mau gosto. (CABANNE, 2002, p. 80).

119 É importante observar que o conto O jardim de veredas que se bifurcam está presente em inúmeras discussões sobre o hipertexto e sobre a narrativa hipertextual e/ou a narrativa nas novas mídias, que o tornaram bastante conhecido entre os interessados por arte e novas mídias. 
Sistema utilizado internamente em alguns jogos computadorizados de xadrez

h1-h4 - a peça que ocupava a casa h1 é movida para a peça h4. Não há referência ao fato da peça movida ser uma Torre.

Após o período de pesquisa e de realização de esboços, que se seguiu às primeiras idéias sobre como o trabalho poderia ser realizado e que antecede a realização desta dissertação, optamos por utilizar a notação algébrica abreviada para apresentar o processo de cálculo executado pelos jogos computadorizados de xadrez. Isso porque o GNU-Chess (o software de xadrez com o qual trabalhamos) só nos permitia escolher entre este sistema e o último da lista acima, que utiliza apenas as casas das peças. Consideramos que este último sistema, por si só, não conseguia expressar a riqueza do jogo, pois capturas, roques, xeques e outros movimentos eram reduzidos à enumeração das casas do tabuleiro, enquanto que o Sistema Algébrico utiliza diversos símbolos para marcar estes eventos. Exemplos:

Dh8+ - Dama na casa h8. Xeque.

Th1\# - Torre na casa h1. Xeque-Mate.

Bxe4 - Bispo captura a peça que ocupava a casa e4.

$\mathrm{a} 1=\mathrm{D}-$ Peão preto chega à primeira linha e é promovido à Dama ${ }^{120}$

Após a escolha do sistema de notação, esboçamos o modo de funcionamento do trabalho, que seria composto por um software de xadrez, jogando contra ele mesmo, e pela apresentação, em tempo real, dos cálculos executados pelo jogo. Entretanto, este modo de funcionamento se mostrou inviável para um trabalho de net arte, pois precisaríamos executar o software do jogo num servidor, ou, então, reprogramar o jogo em uma linguagem de programação que pudesse ser executada pelos visitantes de um site (como ActionScript ${ }^{21}$ ou Java), já que ele foi originalmente programado em C, tal como foi feito pelos autores de Thinking Machine 4 (desenvolvido em Java). Tal tarefa exigiria muito tempo de programação, além de exigir um conhecimento matemático que está além daquele que possuímos. Chegamos a pesquisar alguns jogos de xadrez programados em Java, mas o seu

120 Peões pretos se deslocam da linha 7 em direção à linha 1.

121 Linguagem de programação utilizada pelo softwware Adobe Flash . 
atual estado de desenvolvimento estava muito aquém do GNU-Chess e de outros softwares de xadrez programados em $\mathrm{C}$ e $\mathrm{C}++$.

Para superar estes obstáculos, reelaboramos o modo de funcionamento da seguinte forma:

- utilizamos o jogo de xadrez GNU-Chess, e fizemos com que ele jogasse contra ele mesmo;

- desenvolvemos um pequeno software em Java que coleta os cálculos e os lances realizados pelo GNU-Chess, e os salva num arquivo de dados no formato XML (um formato padrão para troca de dados entre aplicativos destinados à web);

- desenvolvemos a parte visual do trabalho em Flash. Esta parte do trabalho lê os dados da partida salva anteriormente (cálculos e lances efetivamente realizados) e os apresenta na forma de uma animação;

- para garantir uma diversidade de jogos, salvamos os dados de sete partidas diferentes. Assim, a cada vez que o trabalho é acessado, ele sorteia um dos sete jogos para ser exibido.

Criamos duas versões para o trabalho. Na primeira, a tela é dividida verticalmente em duas partes, uma com fundo branco e a outra com fundo preto. No retângulo branco, são exibidos os lances e os cálculos realizados pelas peças brancas, e, no retângulo preto, os lances e os cálculos realizados pelas peças pretas. Os cálculos são sempre escritos em cinza, e são rapidamente alterados. Como no jogo de xadrez os adversários se alternam para jogar, o foco de movimento (isto é, os cálculos em alteração contínua, escritos em cinza) do trabalho oscila entre os lados branco e preto, até o final do jogo. 


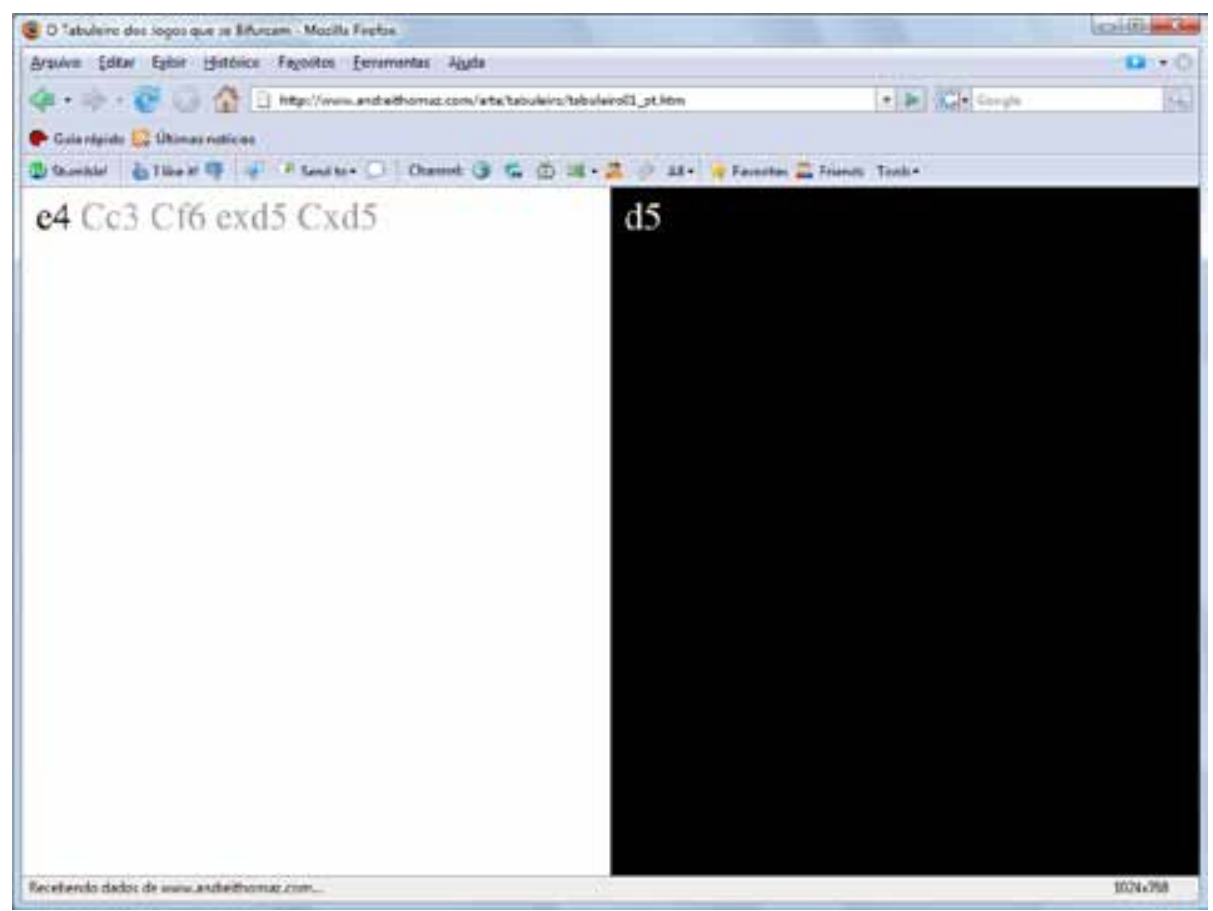

Ilustração 59. O início da primeira versão de O tabuleiro dos jogos que se bifurcam.

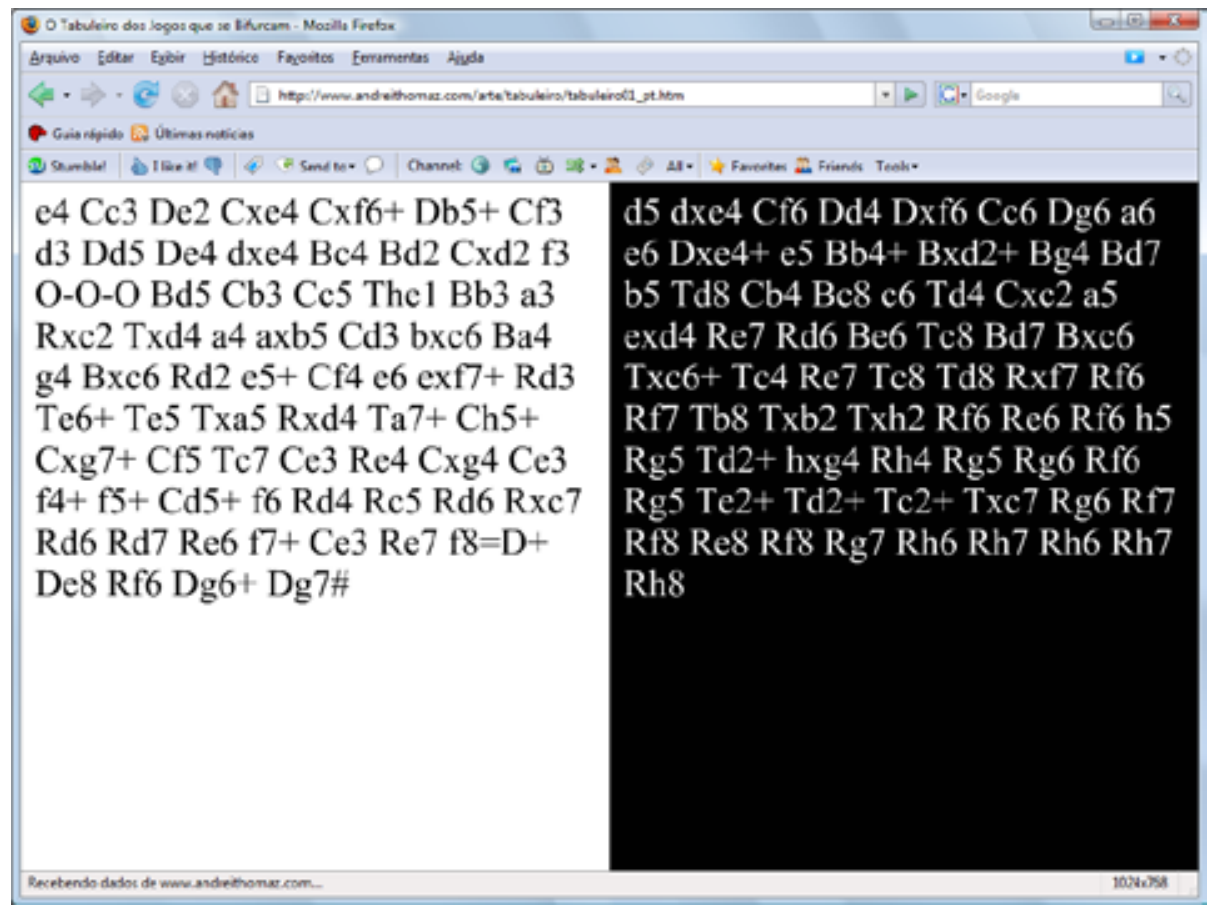

Ilustração 60. O final da primeira versão de $O$ tabuleiro dos jogos que se bifurcam.

Já na segunda versão do trabalho, os lances e os cálculos não são separados pelo lado que os realizam; eles são simplesmente listados, um após o outro. Entretanto, a cor de fundo do trabalho sofre alterações: quando as brancas jogam, o fundo é branco; quando é a vez das pretas jogarem, torna-se preto. No final, o fundo fica com a cor do lado vencedor. 


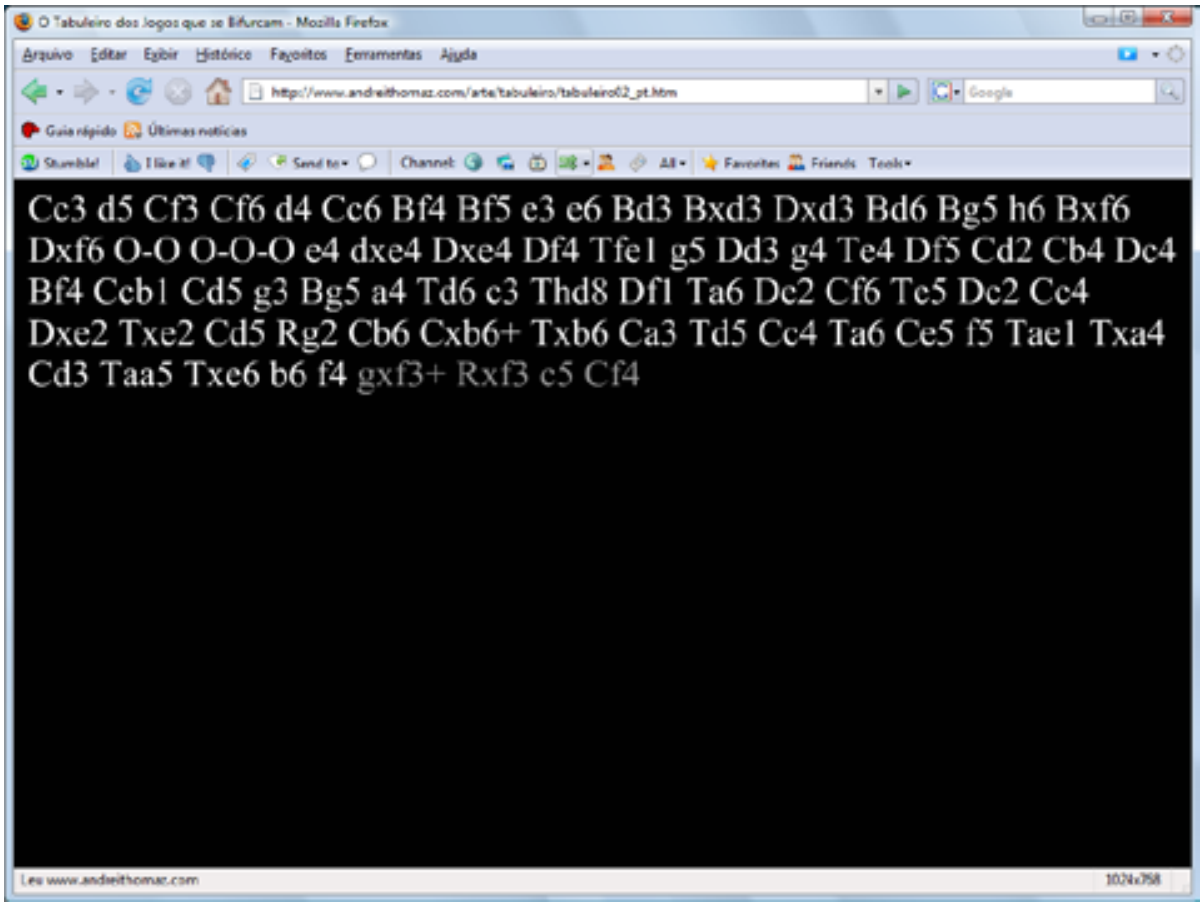

Ilustração 61. Segunda versão de $O$ tabuleiro dos jogos que se bifurcam, onde podemos ver os cálculos em cinza. A cor do fundo indica que são as pretas que jogam.

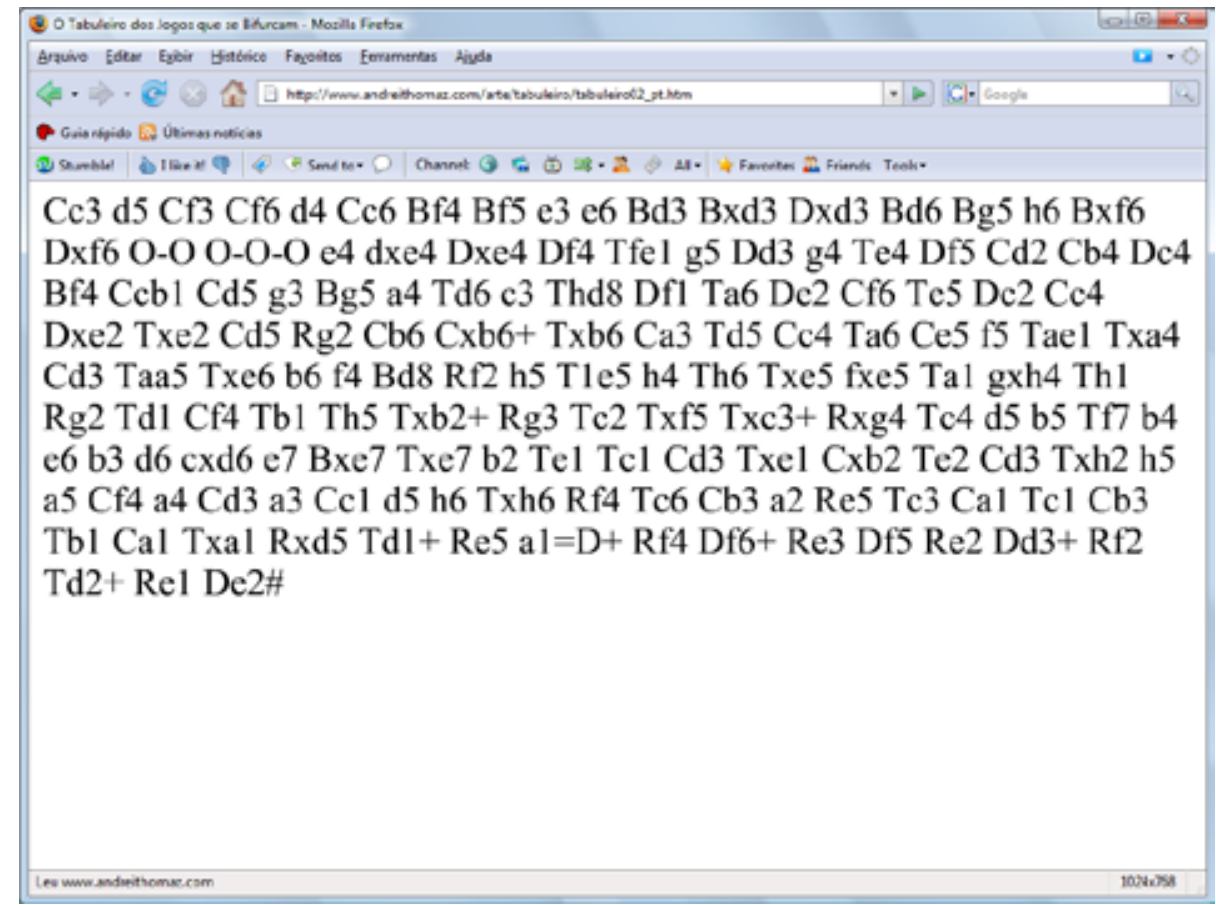

Ilustração 62. Aqui, temos o trabalho após o encerramento do jogo, com o De2\# representando o xeque-mate dado pela Dama, e o fundo branco indicando que a partida foi vencida pelas peças brancas.

Além dessas duas versões para a Internet, também pretendemos apresentar a primeira versão em um contexto expositivo, utilizando, preferencialmente, duas telas, de modo a ressaltar a tensão e o movimento que estão presentes numa partida de xadrez. Removemos as peças do jogo (e a beleza estética da sua movimentação pelo tabuleiro) para ressaltar os processos de cálculo (seja 
dos jogadores, seja dos softwares de xadrez) mas tivemos a intenção e o cuidado de preservar, mesmo que de forma sutil e codificada, o movimento ao qual se refere Duchamp em seus comentários sobre o xadrez. Para ele, a beleza do jogo está nos movimentos imaginários, pensados pelos jogadores, enquanto avaliam qual será o seu próximo lance e a resposta do adversário. 




\section{F Somewhere in Time}

Somewhere in Time ${ }^{122}$ foi concebido a partir das nossas leituras sobre a construção do tempo no cinema, realizadas para o estudo do tempo nos jogos eletrônicos, combinada com a pesquisa sobre os arquivos de legendas de filmes, criados para serem aplicados em filmes baixados da Internet ${ }^{123}$.

O trabalho possui três momentos principais, com o primeiro consistindo na tela que exibe os dados sobre o carregamento das legendas necessárias para o seu desenvolvimento. São utilizadas oito legendas, sorteadas a cada visualização do trabalho, dentro de um conjunto de 25 legendas. Nenhuma informação sobre o que está sendo carregado é dada ao interator; temos apenas números, em formatos de hora (hh:mm:ss) avançando sem parar, acompanhados pela mensagem "carregando dados", que informa o percentual já carregado. Não são dadas pistas sobre o que representam as horas / números.

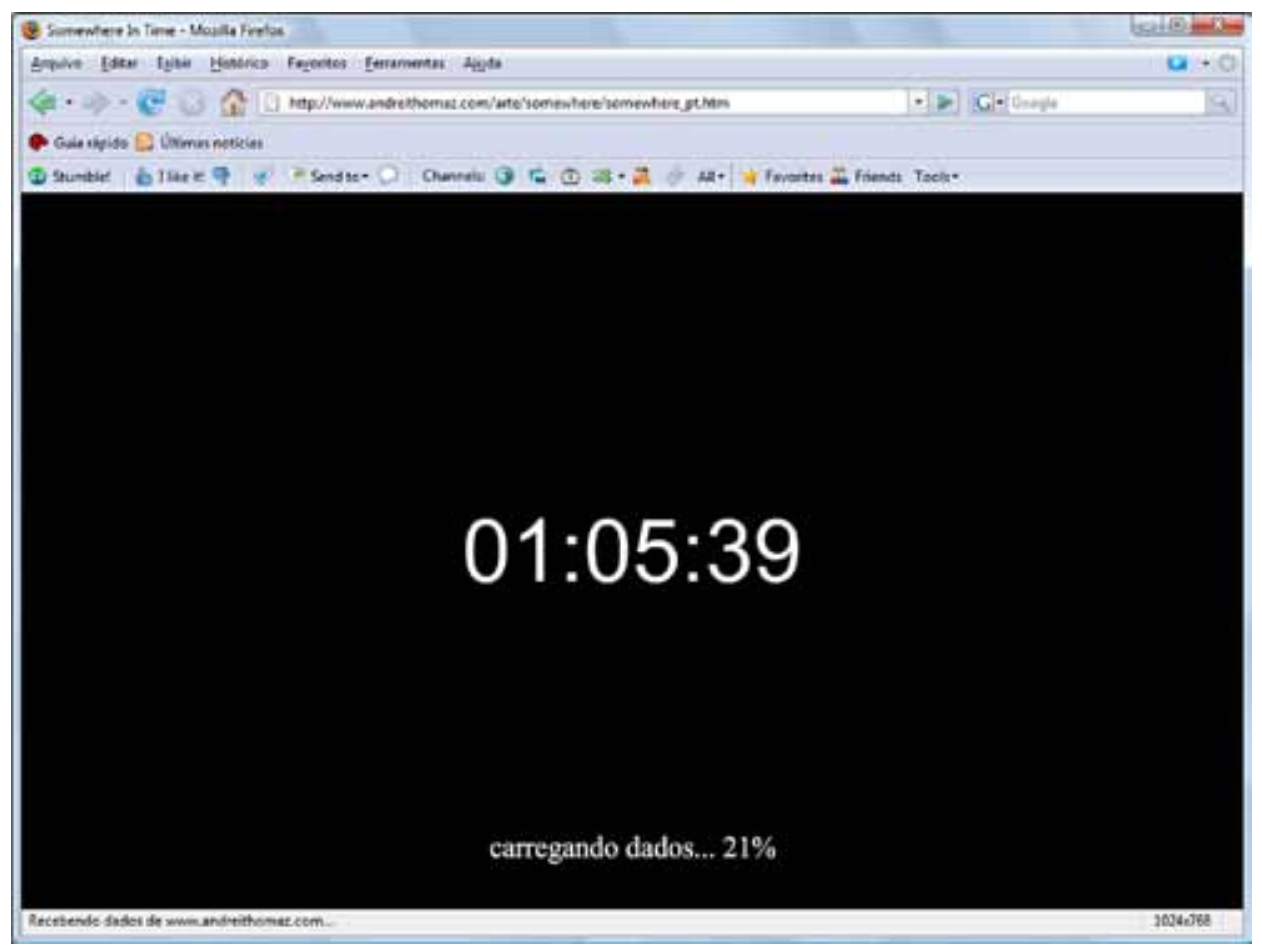

Ilustração 63. Primeira etapa de Somewhere in Time.

No segundo momento, temos uma vasta grade, contendo inúmeras "horas" diferentes. Para entender a origem destas "horas", precisamos explicar o que são os arquivos de legendas de filmes.

122 http://www.andreithomaz.com/arte/somewhere

123 Usualmente com o uso de softwares como o eMule. 
Eles surgiram com a popularização de programas de download de arquivos, utilizando conexões do tipo peer to peer (ponto a ponto), que permitem a troca de arquivos diretamente entre usuários, sem que seja necessário hospedá-los em servidores. Essa possibilidade permitiu que a troca de arquivos, principalmente de músicas e filmes, usualmente protegidos por direitos autorais, se tornasse uma prática comum nos últimos anos. Isto porque a troca se dá diretamente entre computadores particulares, tornando mais difícil a responsabilização dos proprietários dos servidores pela violação de direitos autorais.

No caso dos filmes, estes geralmente são disponibilizados sem legendas. Uma parcela considerável está dublada, em diversos idiomas, mas raramente encontramos algum filme legendado. Para ver um filme com legendas, é necessário procurar pelas mesmas em sites especializados, baixálas e pedir ao programa exibidor de vídeos ${ }^{124}$ que carregue a legenda e a sincronize com o filme. É preciso observar que, apesar da grande disponibilidade de legendas, muitas possuem uma tradução de qualidade apenas razoável. Esta observação é importante porque, na realização de Somewhere in Time, não nos preocupamos em corrigir eventuais erros de digitação ou de tradução no texto das legendas.

Para sincronizar a legenda com o filme, os programas de visualização utilizam as informações contidas nos arquivos. O arquivo de cada legenda é composto por blocos como o de baixo ${ }^{125}$ :

\section{3}

00:56:28,970 --> 00:56:33,870

E um computador da última geração

dos computadores HAL 9000.

Como podemos ver neste exemplo, cada bloco possui as seguintes informações:

- a ordem de aparecimento do bloco (em relação aos outros blocos da legenda);

- o momento em que o texto do bloco começará a ser exibido (em horas, minutos, segundos e

124 Também denominados de players. Exemplos: Windows Media Player, QuickTime, Media Player Classic.

125 Aqui, estamos utilizando o formato de arquivos de legendas SRT, sendo que há outros formatos disponíveis, que são menos populares. 
milissegundos);

- o momento em que o texto deixará de ser exibido;

- o texto que será exibido.

Assim, é a partir das informações sobre o tempo de exibição de cada bloco que a grade de "horas" é gerada, assim como a "contagem" da primeira parte de Somewhere in Time. No início do trabalho, é exibido o tempo de início da exibição de cada bloco que é carregado. Como são carregadas oito legendas (cada uma de um filme diferente) toda vez que um interator visita o trabalho, a contagem é reiniciada oito vezes, sem que se possa ter alguma idéia sobre a razão do reinício da contagem. Quando o carregamento das legendas é finalizado, é gerada uma grade, utilizando-se, mais uma vez, os tempos de início dos blocos de texto:

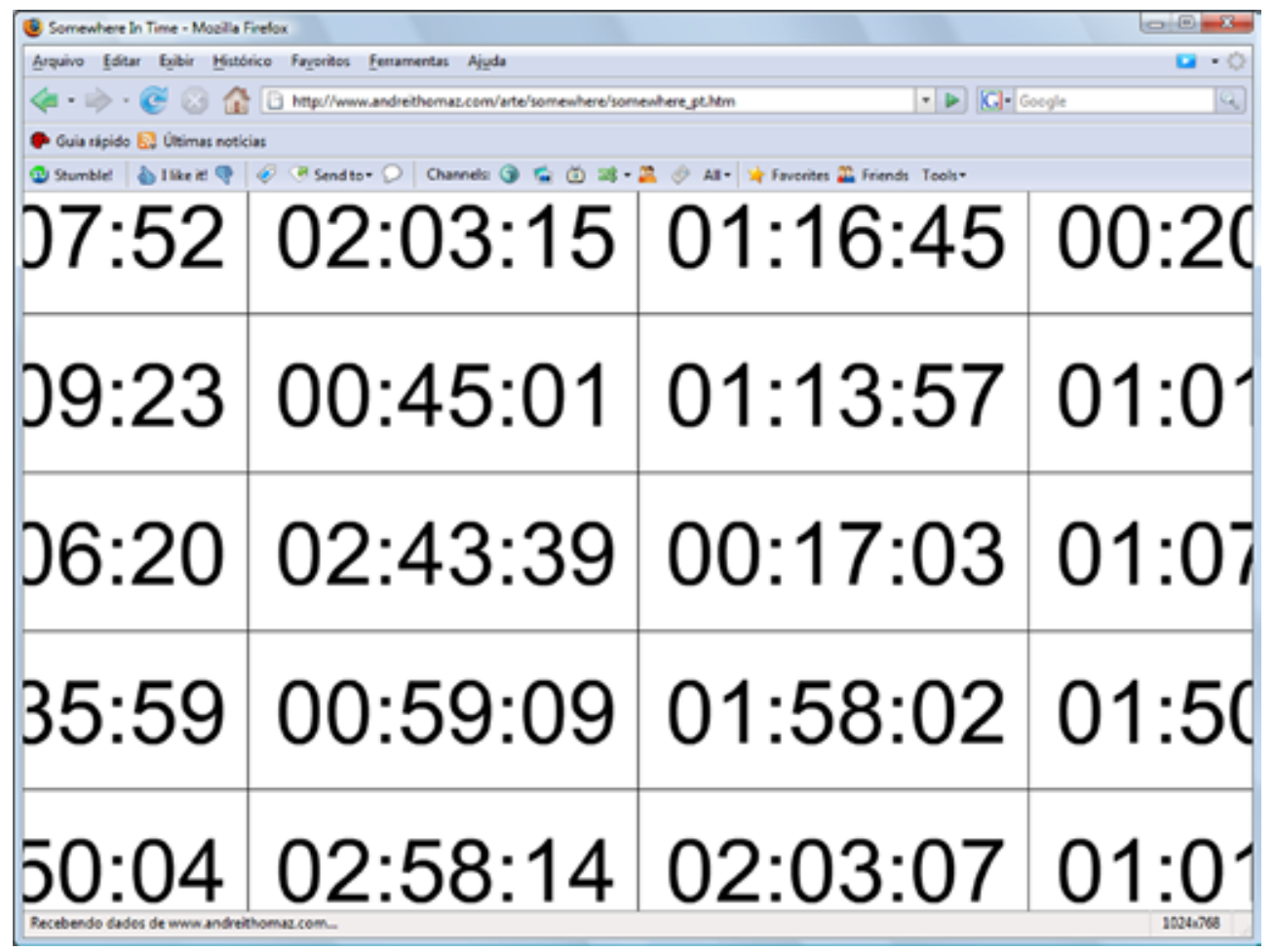

Ilustração 64. Segunda etapa do trabalho.

Ao clicar em algum dos números, o interator assiste a uma seqüência de textos, exibidos na parte inferior da tela, centralizados de maneira parecida com a forma como as legendas são exibidas no cinema. Porém, não há nenhuma imagem; vê-se apenas os textos sobre um fundo negro. Nenhuma informação sobre a origem dos textos é dada ao interator. 


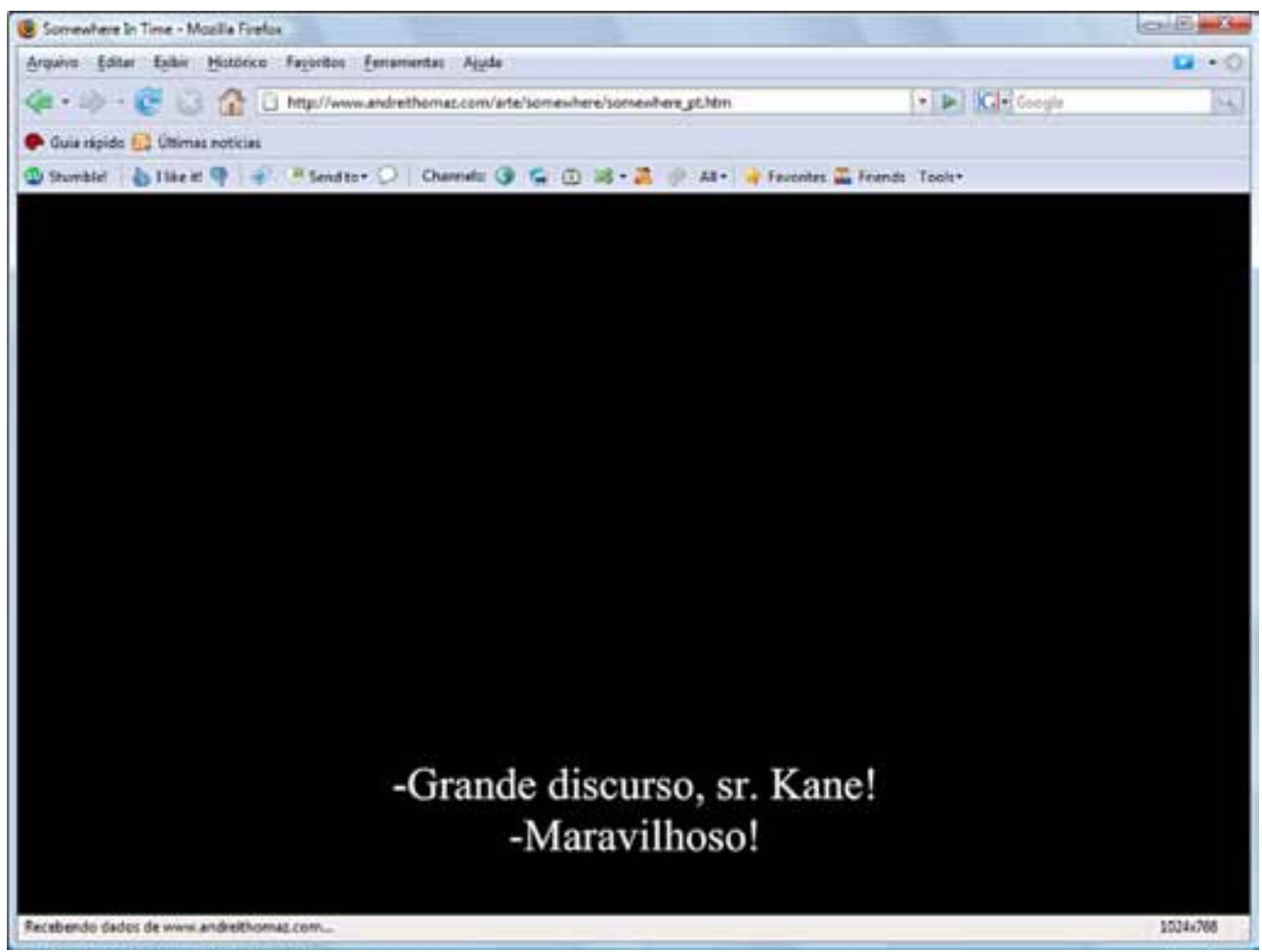

Ilustração 65. Terceiro momento de Somewhere in Time. Neste trecho, temos uma pista da origem do texto (as legendas são do filme Cidadão Kane)

\section{F.1 Uso da poética de fragmentos}

Duas informações importantes sobre os textos não são dadas ao interator, pois acreditamos que elas desmanchariam o prazer de experimentar o trabalho como um desafio, como um conjunto de informações cujas conexões são sugeridas mas não explicitadas.

Primeiro, em nenhum momento se diz que os textos exibidos são legendas de filmes, apesar de que algumas sugestões são feitas neste sentido, tal como o seu posicionamento na tela. Dependendo dos filmes cujas legendas forem sorteadas, a origem do texto poderá ficar muito ou pouco evidente. Por exemplo, o interator poderá ler desde frases contendo elementos marcantes de filmes muito conhecidos ("computador HAL", "cidade de Casablanca", "Saigon”) até frases banais, que não dão nenhuma pista sobre a sua origem. Para selecionar os filmes cujas legendas seriam exibidas neste trabalho, utilizamos dois critérios principais. Primeiro, selecionamos alguns filmes estudados na pesquisa sobre o tempo no cinema (Rashomon, Corra Lola, Corra, Smoking / No Smoking e outros). Segundo, incluímos filmes que, supomos, serão conhecidos da maioria dos interatores, tais como 2001 - Uma Odisséia no Espaço, Casablanca, Apocalipse Now e Matrix. Procuramos uma certa diversidade no perfil dos filmes para não privilegiar um recorte específico na sua seleção. Um filme como 
Rashomon, por exemplo, é pouco conhecido junto ao grande público, o que já não ocorre com $M a$ trix ou, em menor grau, com Apocalipse Now.

Em segundo lugar, não é dito que a grade de horas trata-se, na verdade, de uma espécie de catálogo de tempo. Isto é, nela, o interator seleciona o tempo das legendas que serão exibidas a seguir. Toda vez que o interator clica numa "hora", o trabalho seleciona, entre as legendas carregadas, quais são os blocos que seriam exibidos no momento selecionado, e os mostra em seqüência. Assim, no caso do momento selecionado possuir texto nas oito legendas carregadas, teremos uma seqüência de oito blocos de texto sendo exibida ao interator, sendo que cada bloco será originário de um filme diferente.

Ao negar ao interator as informações detalhadas nos parágrafos anteriores, estamos fazendo uso da poética de fragmentos tal como elaborada por Calabrese e já citada quando abordamos os jogos baseados em texto, no segundo capítulo desta dissertação (a partir da página 46. Neste momento, gostaríamos de relembrar que o espectador de um objeto cultural que faça uso da poética de fragmentos se vê colocado na posição de um detetive, que precisa reconstituir o todo a partir das partes que lhe são oferecidas.

O fragmento é em geral uma porção presente que reenvia para um sistema suposto como ausente. A (pesquisa) mediante fragmentos tem mais o aspecto de um inquérito do que de uma pesquisa analítica. Não é por acaso que em certas disciplinas naturalmente dirigidas ao fragmento se tem muitas vezes a impressão da procura do suspense, isto é, de uma progressão aventurosa em direção a uma solução suposta e eventualmente confirmada.

(CALABRESE, 1987, p. 90. Grifos do autor)

Seria ingênuo esperar que todos os interatores de nosso trabalho consigam identificar as relações existentes entre os tempos e textos exibidos, tais como descritas aqui. Entretanto, temos a intenção de que o interator esboce, em sua mente, alguma relação entre os elementos que lhe são dados, percebendo que está diante de um jogo com o tempo. Também oferecemos pistas sobre a origem dos textos utilizados para que o interator possa, pelo menos, desconfiar que ele está lendo legendas de um ou mais filmes cujas imagens não lhe são mostradas e, assim, tenha alguma curiosidade sobre quais filmes foram fonte das legendas. Por fim, também esperamos que o interator crie esboços de narrativas a partir dos fragmentos textuais associados com cada tempo selecionado por ele. 


\section{F.2 O filme Somewhere in Time e a espacialização do tempo}

Somewhere in time, traduzido como Em algum lugar do passado, é um filme produzido em 1980 cujo personagem principal, vivido por Christopher Reeve, viaja para o passado utilizando técnicas de auto-hipnose. Para o nosso trabalho, o elemento mais importante deste filme é o seu próprio título, que sugere um deslocamento espacial no tempo. Isto é, associa-se uma palavra cujo sentido é espacial (somewhere / em algum lugar) ao tempo (aqui, time, no original, mostra-se mais ambígua do que a tradução portuguesa, passado), espacializando-o.

É esta operação de espacialização do tempo que é executada pela grade de tempo, presente na segunda parte do trabalho aqui apresentado: ela permite ao nosso interator escolher qual o fragmento de tempo que será visitado, sem qualquer tipo de ordenação. Todos os tempos encontrados nos arquivos de legenda são dispostos na grade para serem percorridos pelo interator, da forma como este desejar. Percebemos aqui a realização de uma dupla, talvez tripla, codificação do tempo: se os tempos expressos nas legendas linearizam o fluxo temporal dos filmes (compostos por condensações, elipses, flashbacks e diversas outras formas de manipulação / organização do tempo), por outro lado a grade quebra as duas organizações temporais prévias (do filme e da legenda), colocando todos os fragmentos de tempo no mesmo espaço, lado a lado, simultaneamente, e dificultando, pela sua extensão, a organização / ordenação dos fragmentos pelo olhar do interator.

\section{F.3 A grade e seus aspectos labirínticos}

As grades, enquanto instrumentos de análise, baseiam-se no espaço cartesiano, que realiza uma organização do espaço ao longo dos eixos x, y e, no caso do espaço tridimensional, z. Assim, estão ligadas à idéia de ordem e organização, sendo que uma das suas manifestações mais recentes (e presentes dentro das mídias digitais) são as planilhas de dados, utilizadas para calcular orçamentos, elaborar estatísticas e inúmeras outras tarefas. 


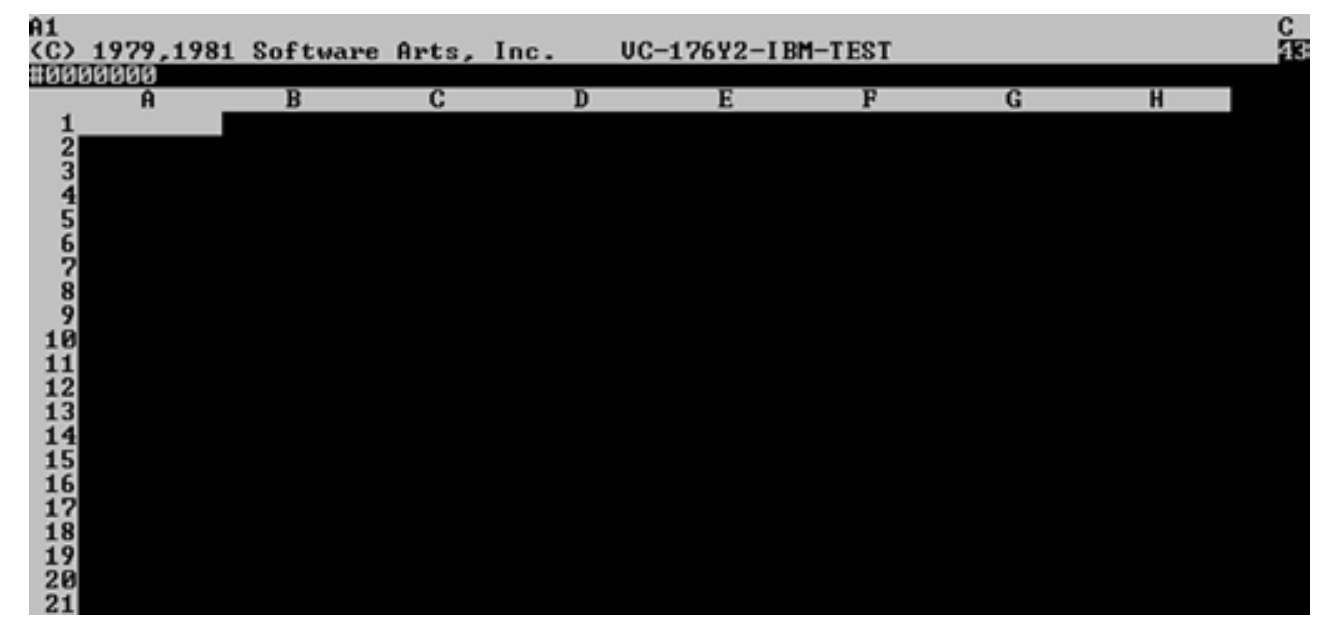

Ilustração 66. Tela do VisiCalc, primeiro programa de planilha criado para computadores pessoais.126

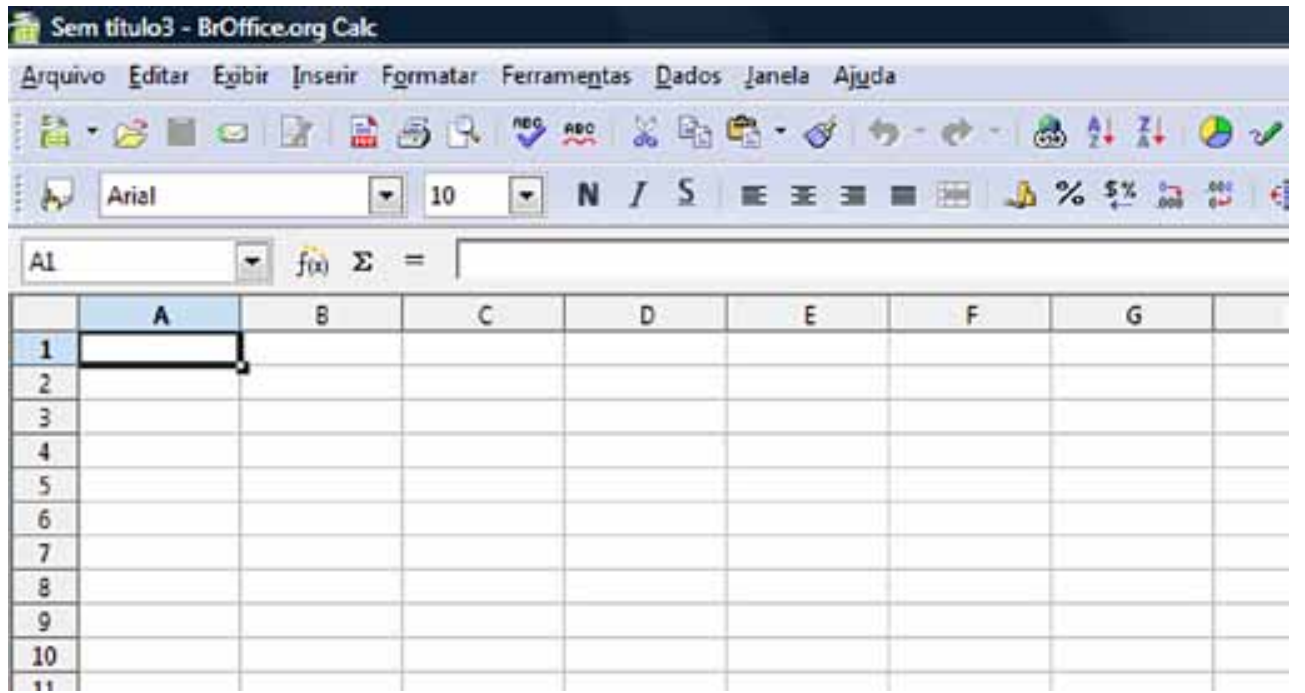

Ilustração 67. Tela do OpenCalc, programa de planilha do pacote OpenOffice, distribuído como software livre. Versão de 2008.

Em Somewhere in Time, a grade utilizada como catálogo de tempo ganha aspectos labirínticos por sugerir uma organização que não é explícita. Temos um agrupamento aparentemente caótico e aleatório, mas que, ao mesmo tempo, exibe indícios de possuir algum tipo de princípio lógico. Esta é, de acordo com Calabrese, uma das características do labirinto: "o labirinto é apenas uma das muitas figuras do caos, entendido como complexidade, cuja ordem existe, mas é complicada ou oculta" (CALABRESE, 1987, p. 145). Para nós, criar a impressão de haver alguma ordem oculta é essencial para este trabalho. Por este motivo, recorremos à forma da grade, e não a outras organizações espaciais, que poderiam ressaltar o aspecto aleatório da distribuição dos “tempos” pelo espaço da tela.

126 Fonte: http://en.wikipedia.org/wiki/Image:VisiCalc_\%28IBM_PC\%27s_Killer_Application\%29.PNG. acessado em 20/04/2008. 

n+ fitur

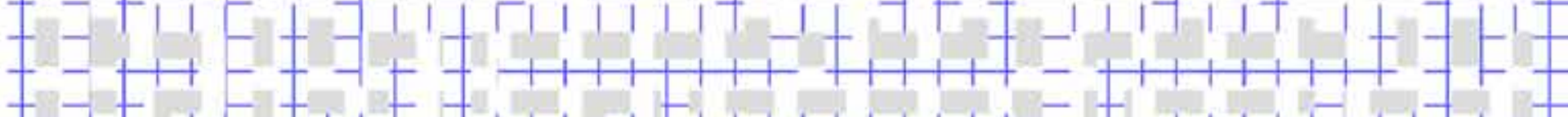
捕五

$+\pi+1+1+10$

+77 讨 in it+ it

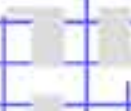

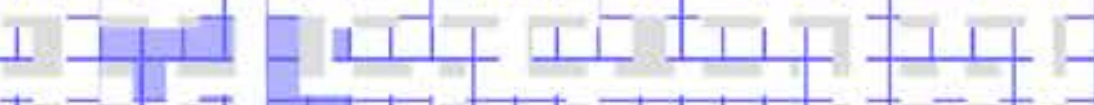

Int 17 $+1=$

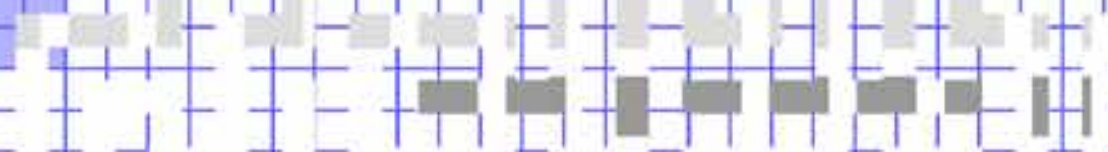

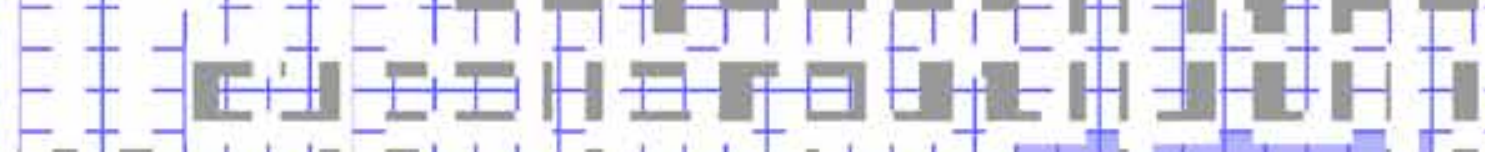
F-1 -

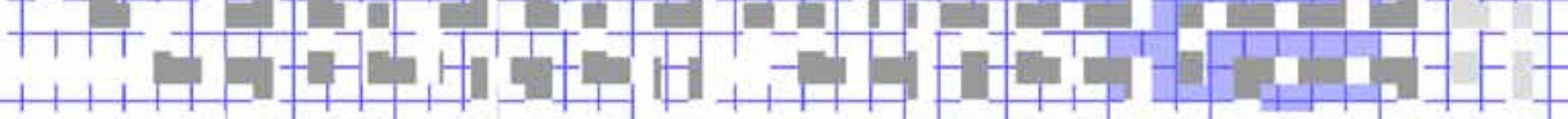

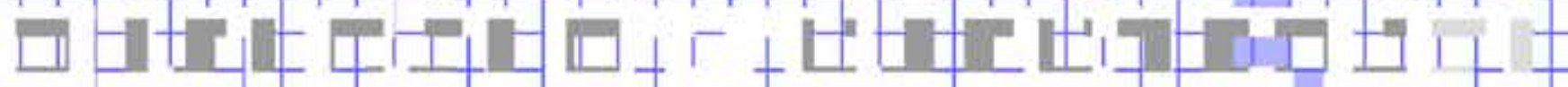

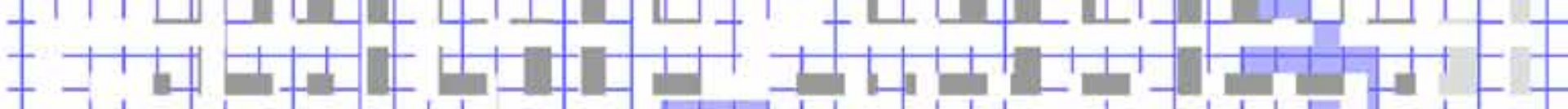

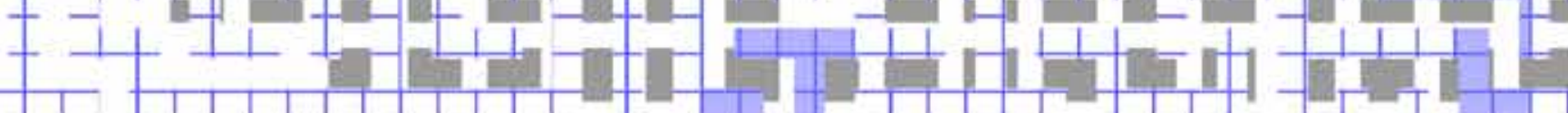

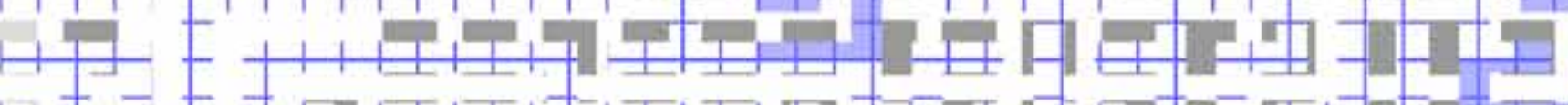
等

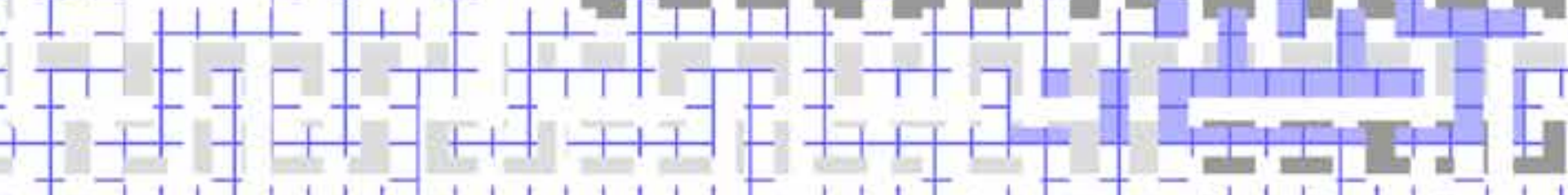

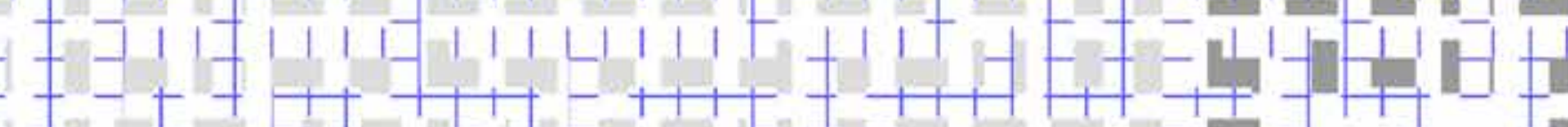
$-1+1+1$

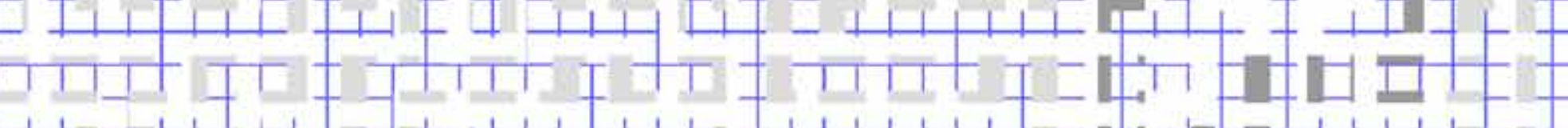

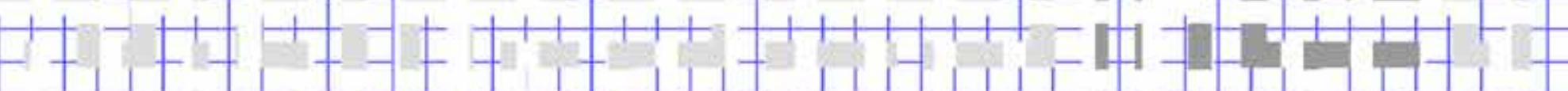

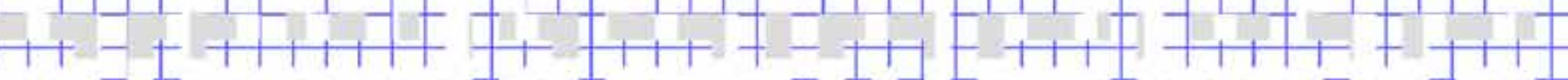

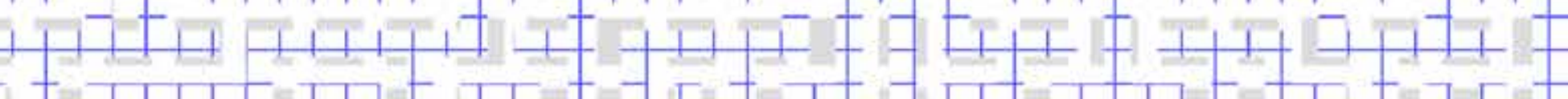

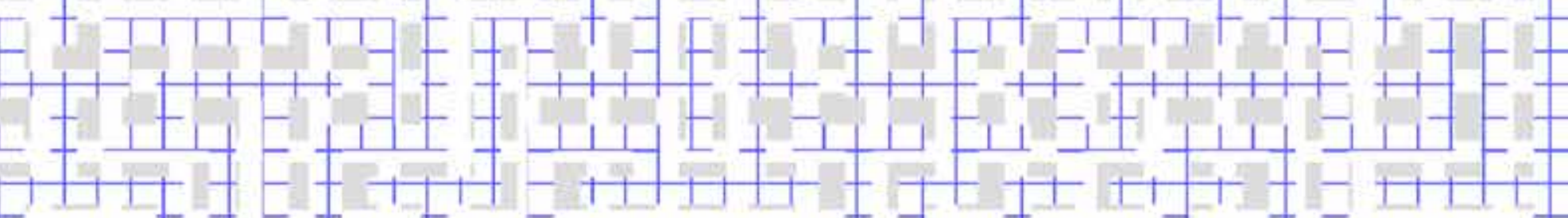
+ 



\section{G Tetris: estudos}

Tetris foi criado pelo matemático russo Alexey Pajitnov em 1984 (DE MARIA, WILSON, 2003, p. 196) e se tornou um dos principais títulos da história dos jogos eletrônicos, estando fortemente associado a dispositivos portáteis (como o GameBoy da Nintendo). O jogo utiliza peças compostas por quatro quadrados, em diferentes combinações, que caem a partir da parte superior da tela. A função do jogador é girar as peças de forma que, ao chegarem na base da tela, elas se encaixem nas peças já existentes, sem deixar nenhum quadrado vazio.
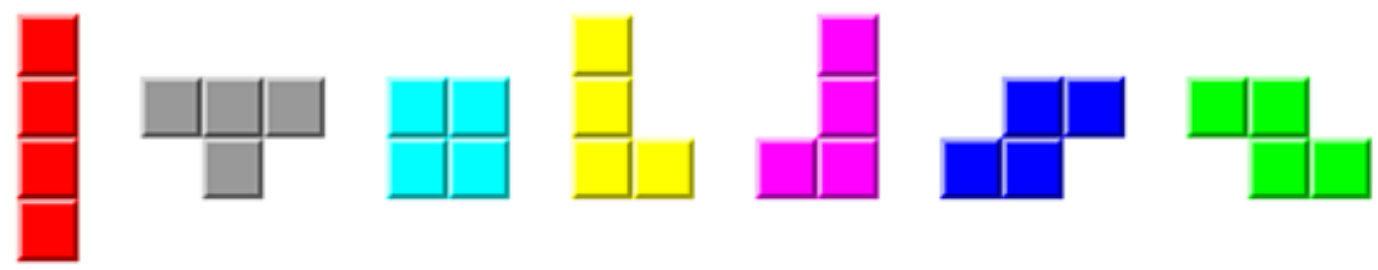

Ilustração 68. As peças utilizadas por Tetris ${ }^{127}$.

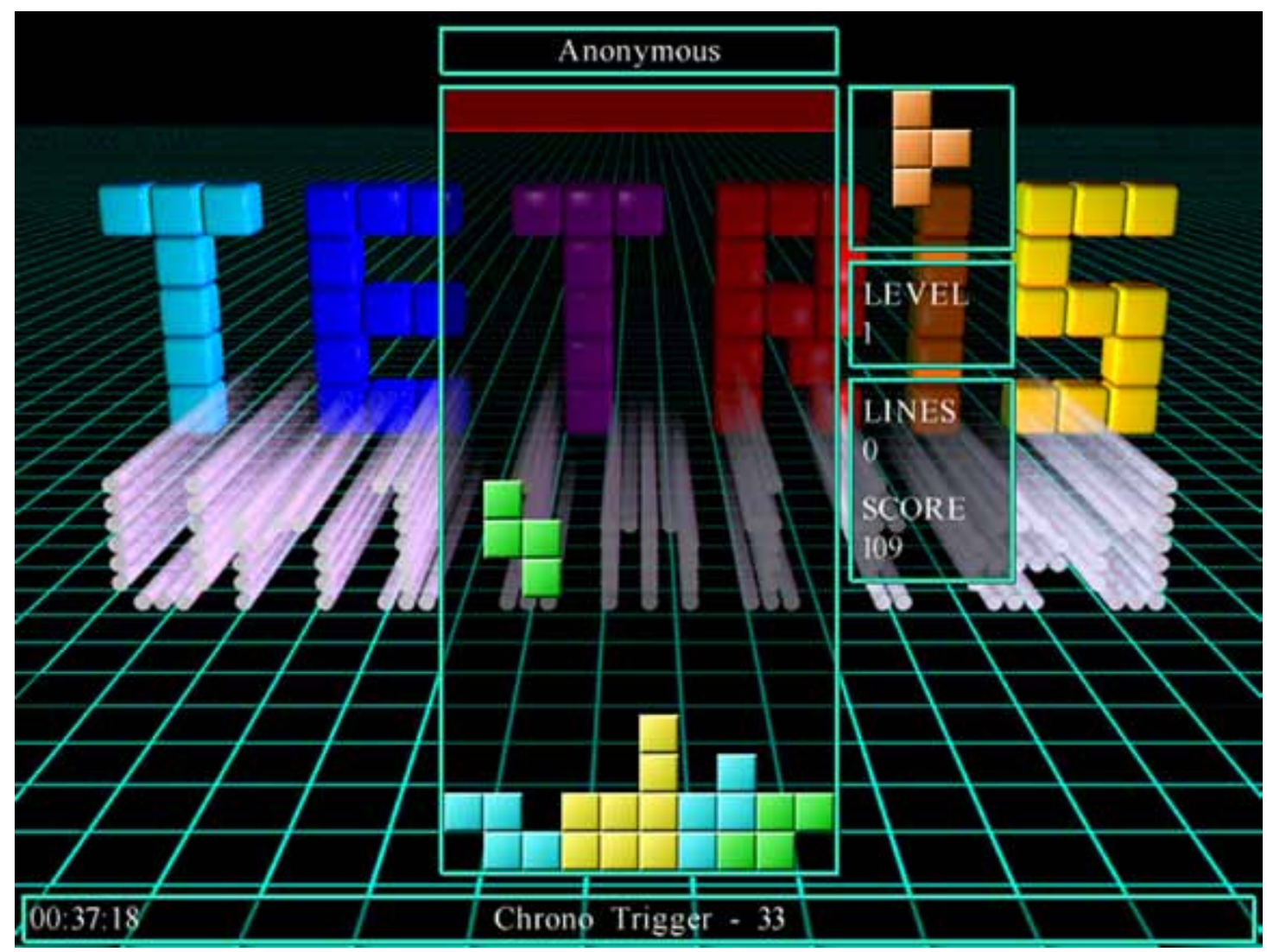

Ilustração 69. A mecânica de Tetris: quando a peça verde chegar ao final da tela, ela completa a linha, que desaparecerá. 
Quando uma linha é completada, ela desaparece do tabuleiro, e as peças acima são movidas para baixo. À medida que o jogador não consegue completar uma linha, o conjunto de linhas incompletas aumenta até que, quando a pilha chega ao topo da tela, o jogador perde.

Baseando-nos em Tetris, criamos Tetris: $e^{2 t u d o s^{128}}$, composto por quatro modificações do jogo, disponibilizadas na Internet e também em versão para celulares. Apenas as características visuais do jogo foram modificadas; sua mecânica de funcionamento permanece a mesma. Nosso interesse principal foi explicitar a grade (o plano cartesiano) que organiza o espaço do jogo, e que permanece em segundo plano no jogo original. Isto é feito de diversas maneiras. No primeiro estudo, desenhamos uma grade no fundo do jogo, e deixamos todas as peças com a mesma cor, de modo a ressaltar a forma criada pelo agrupamento das mesmas (o que não ocorre no jogo original, devido à diversidade de cores das peças).

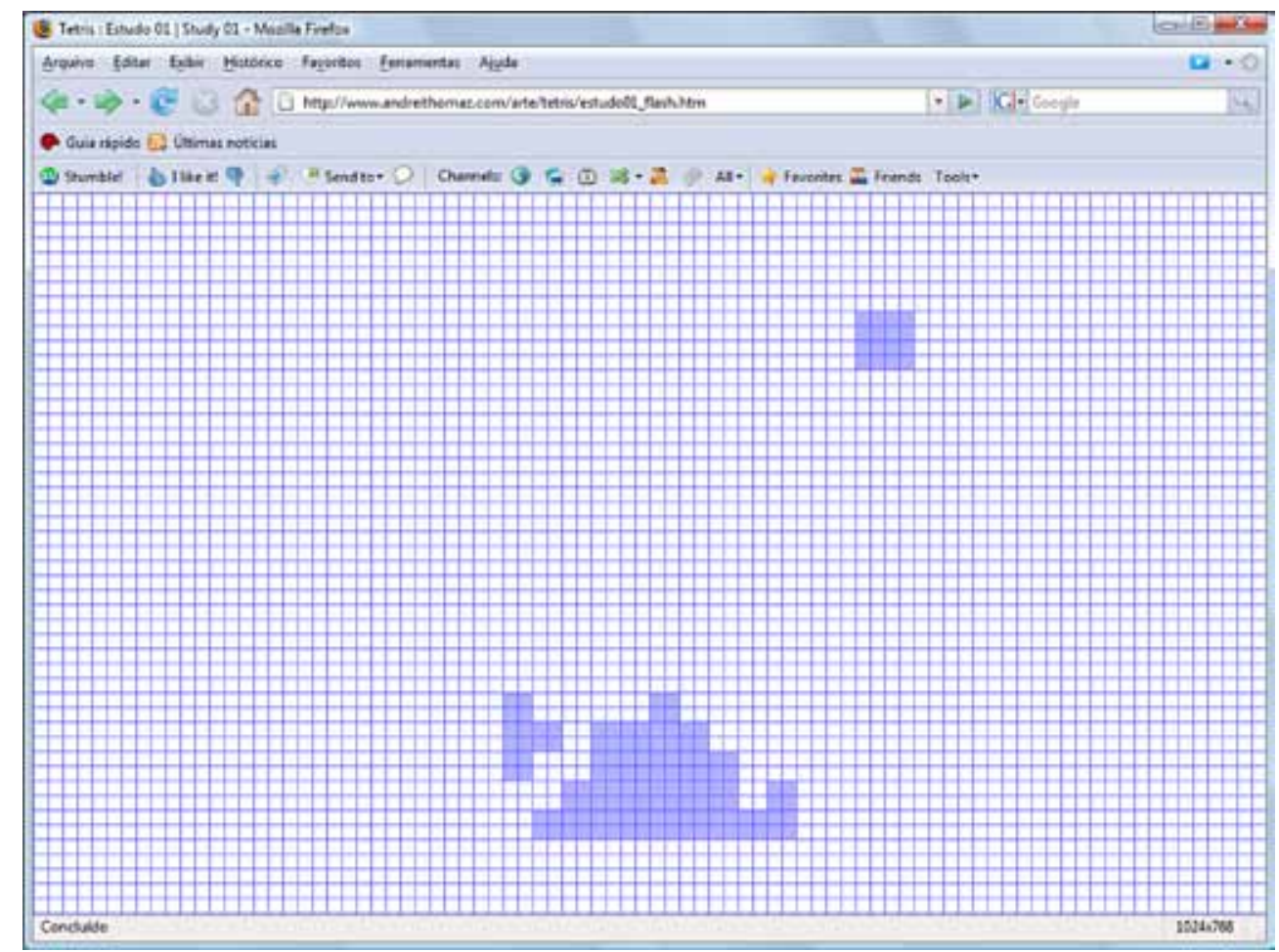

Ilustração 70. Tetris : Estudo \#1.

No segundo estudo, mantivemos as diferentes cores de cada peça mas, em compensação, desenhamos quadrados nos espaços vazios, de modo a diminuir o contraste entre casas cheias e espaços vazios, tal como ocorre no jogo original. 


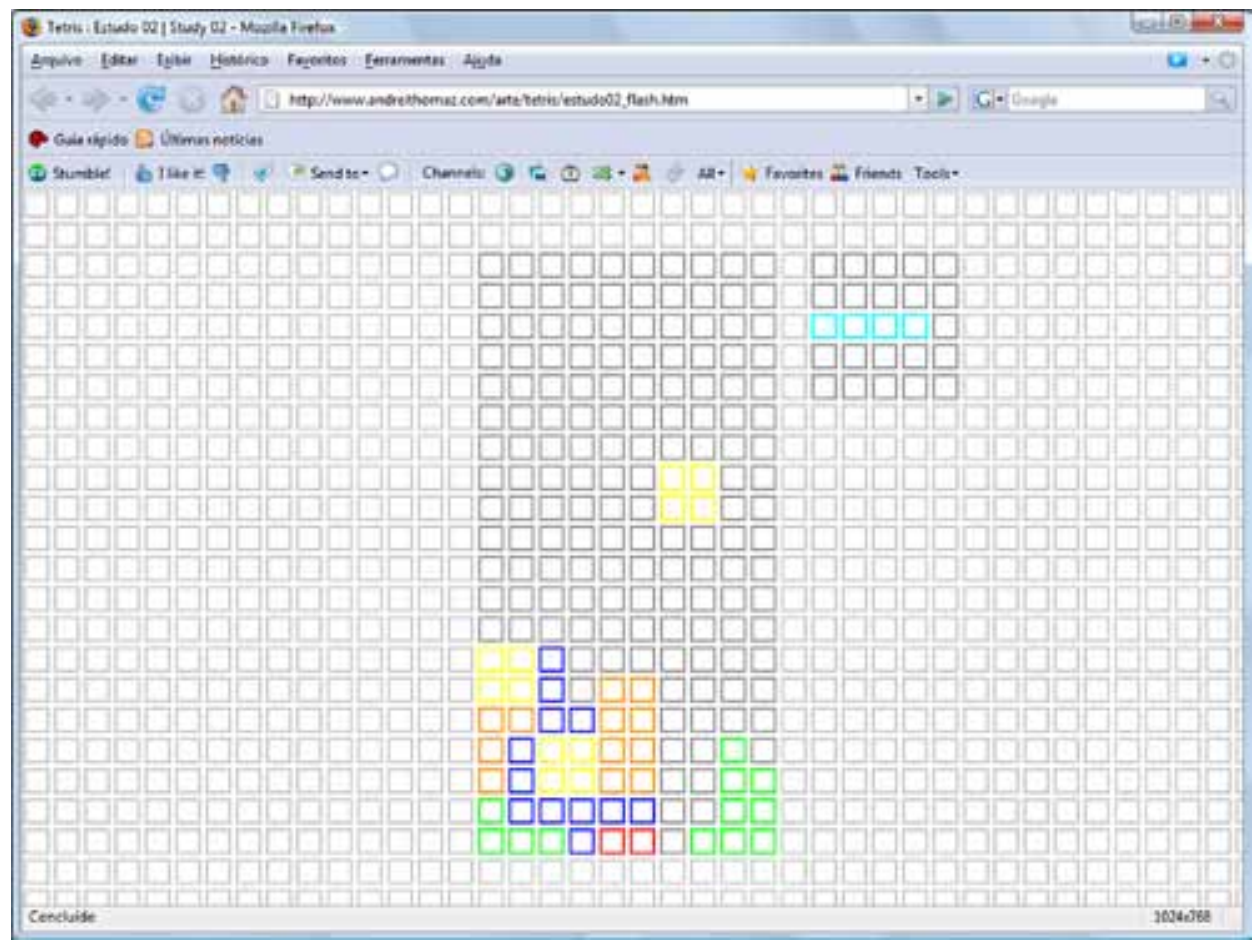

Ilustração 71. Tetris : Estudo \#2.

No terceiro estudo, invertemos a relação entre os quadrados ocupados pelas peças e o fundo do espaço do jogo: este passa a ser ocupado por quadrados cinzas, enquanto que as peças são representadas por espaços vazios.

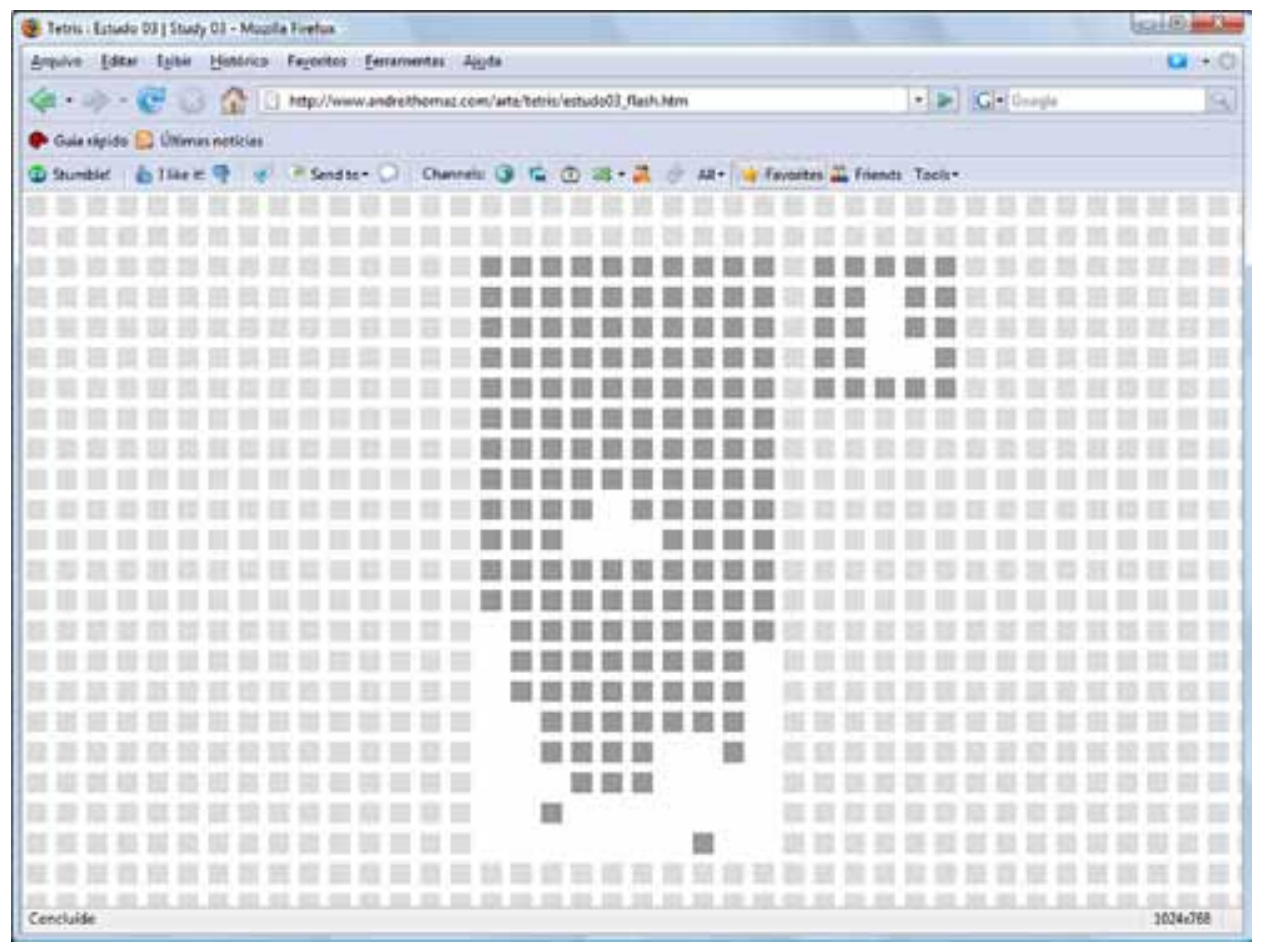

Ilustração 72. Tetris : Estudo \#3. 
Finalmente, no quarto estudo, todas as casas, vazias ou ocupadas, são representadas por pontos coloridos, de modo a homogeneizar o espaço e ressaltar a grade que o organiza:

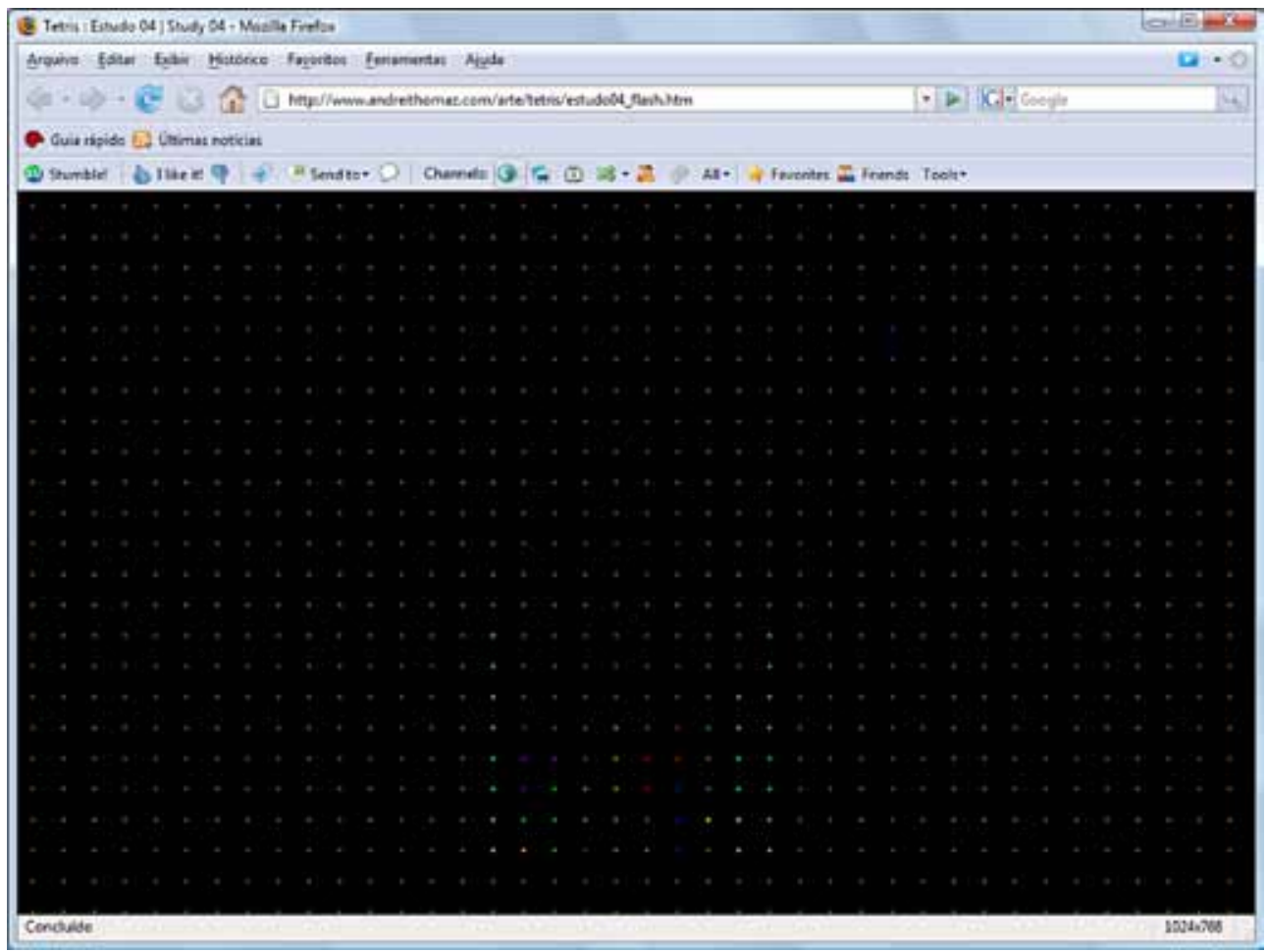

Ilustração 73. Tetris : Estudo \#4.

Apesar deste trabalho não contemplar, diretamente, o assunto principal desta pesquisa, gostaríamos de observar que o nosso interesse por grades surgiu durante a elaboração de labirintos, com a confecção de desenhos dos mesmos sobre papéis dos tipos quadriculado e milimetrado. A transformação de um espaço organizado (a grade) em um espaço labiríntico é um procedimento que nos interessa, e que também pode ser encontrado no trabalho Somewhere in Time, apresentado na página 135 . 


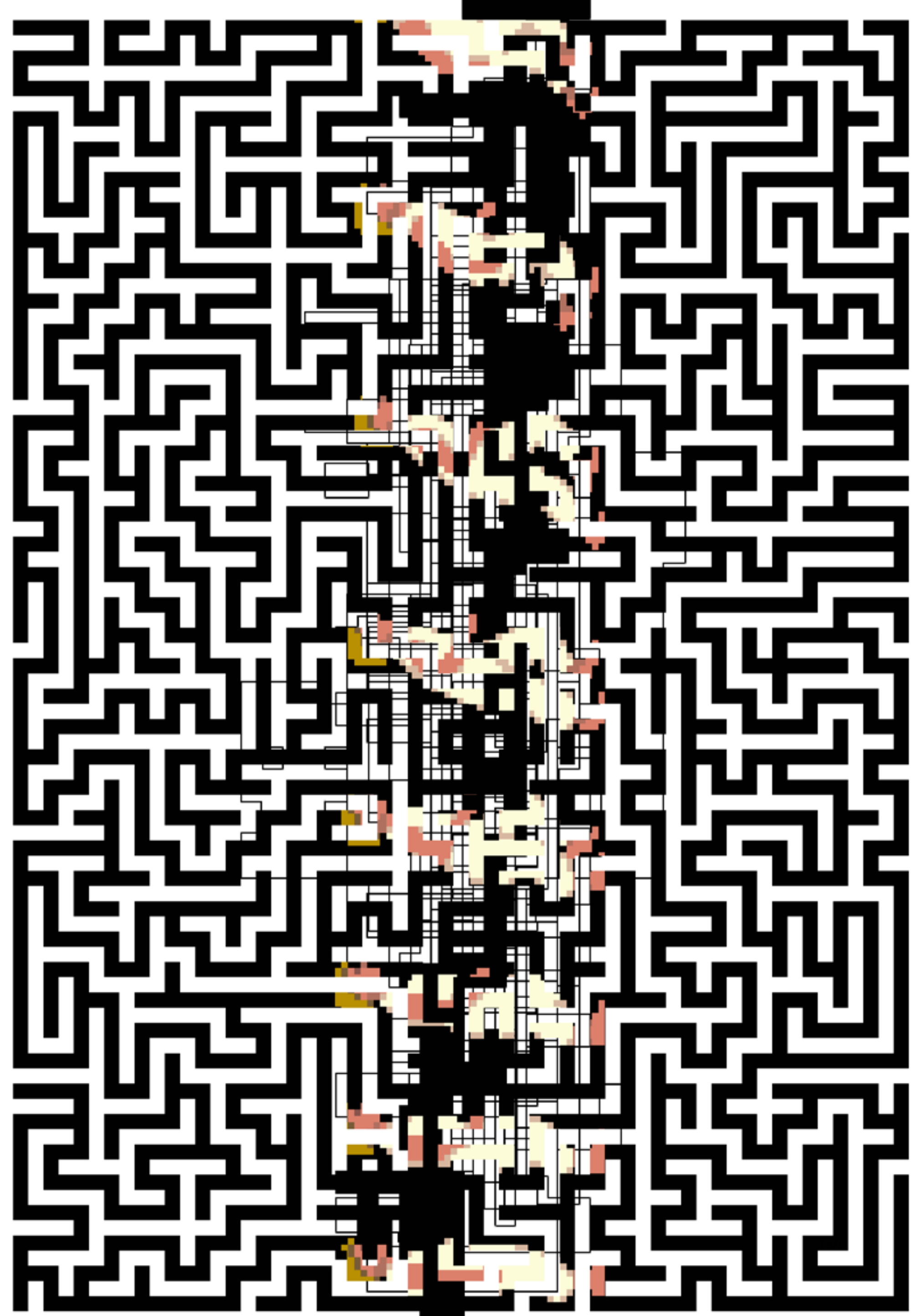





\section{H Prince of Persia: Estudos}

O jogo Prince of Persia, foi desenvolvido por Jordan Mechner, e lançado com 1989 com distribuição da Broderbund (DE MARIA, WILSON, 2003, p. 292). Como descrevemos, com mais detalhes, este jogo no capítulo sobre as manifestações do labirinto nos jogos eletrônicos, a partir da página 62, aqui vamos nos deter somente sobre o trabalho desenvolvido a partir do mesmo.

Iniciamos os primeiros trabalhos com o jogo Prince of Persia com o objetivo de identificar e revelar como se dava a presença do labirinto neste jogo. Entretanto, devido a uma necessidade de entender os elementos formais do jogo (isto é, como se dá a construção dos cenários, as possibilidades de ação, a marcação dos eventos do jogo e assim por diante), realizamos um conjunto de 15 estudos onde analisamos diversas características e elementos do jogo.

Os estudos de 1 a 6 apresentam uma decomposição dos movimentos do personagem principal, controlado pelo jogador, com o uso de um procedimento semelhante ao de Eadweard Muybridge e de Étienne-Jules Marey, nas suas pesquisas com fotografias de objetos em movimento (cronofotografias).
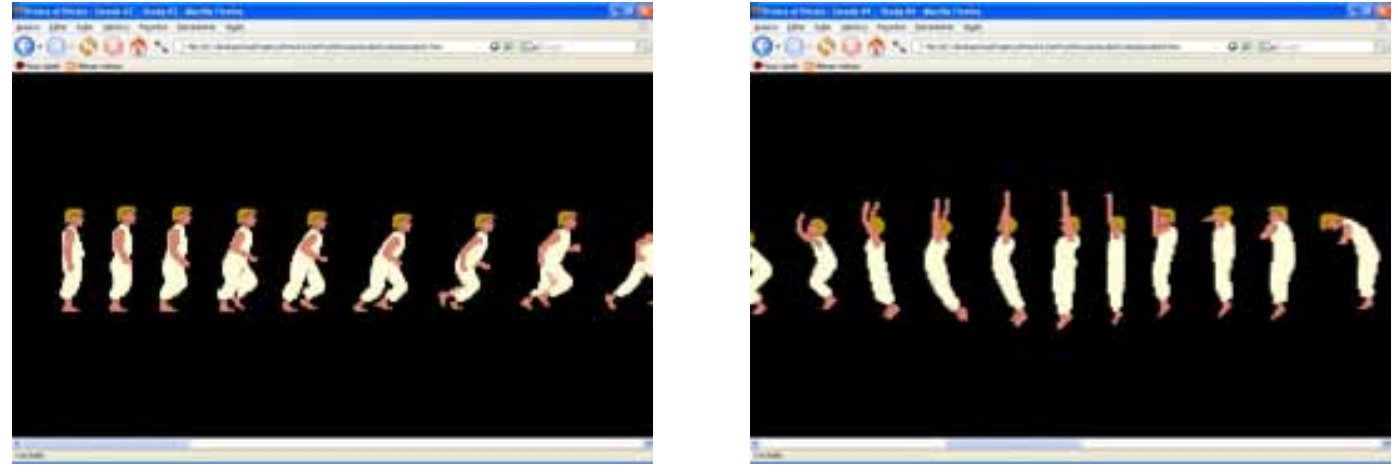

Ilustração 74. Imagem de Prince of Persia: Estudo \#2 (à esq.) e Prince of Persia: Estudo \#4 (à dir.)

O estudo número 7 é um dos estudos que, junto com o de número 10, abordam a presença do labirinto em Prince of Persia. Neste trabalho, apresentamos um conjunto de seis animações simultâneas (ao todos, são três conjuntos, num total de 18 animações), simulando uma sala de vigilância onde se tem acesso às imagens sendo capturadas em tempo real por câmeras de vigilância, espalhadas por um espaço determinado. Nosso objetivo, ao apresentar tantas imagens do espaço do jogo, é o de destacar a sua extensão e o seu traçado que lembra um labirinto. 

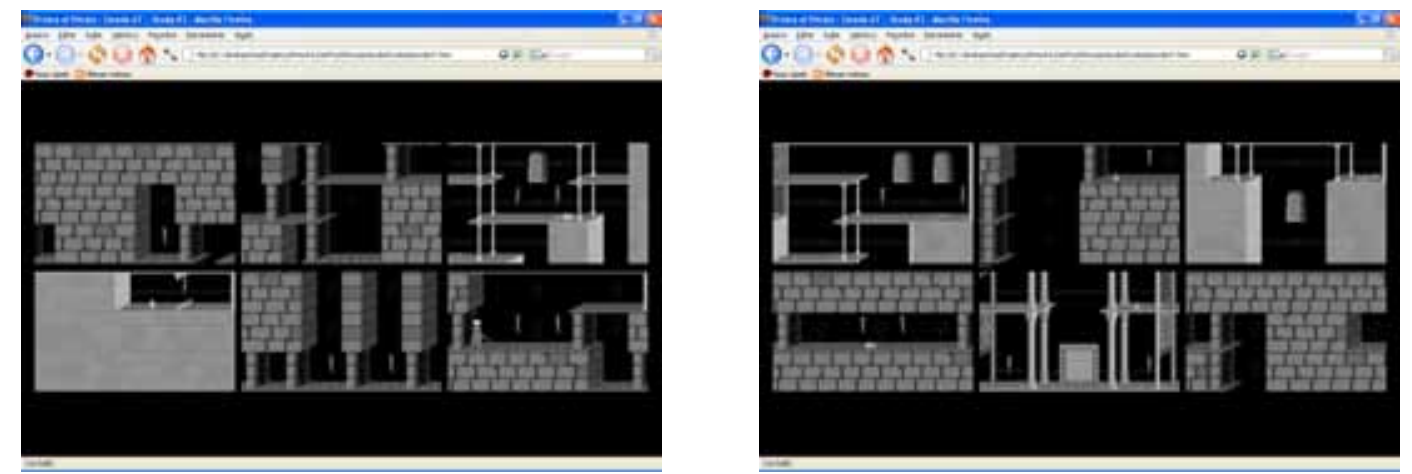

Ilustração 75. Imagens de Prince of Persia: Estudo \#7.

É este traçado que será trabalhado pelo estudo número 10. Ele apresenta os traçados de cada um dos níveis do jogo, apresentados seqüencialmente, como formas abstratas. O espectador não recebe nenhuma indicação da origem das formas geométricas que lhe estão sendo exibidas.
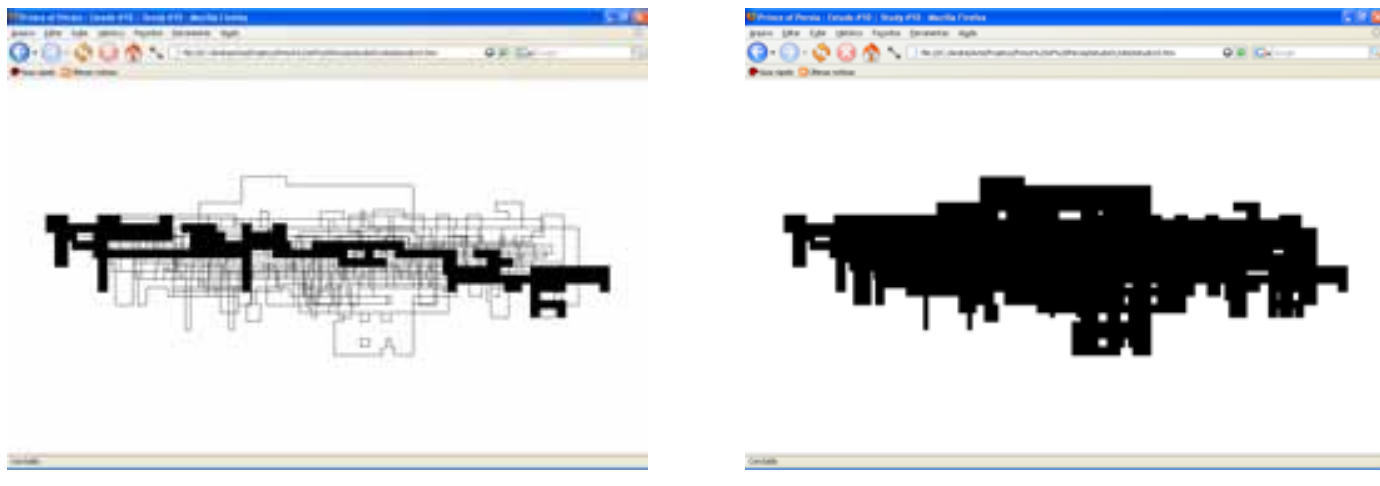

Ilustração 76. Imagens de Prince of Persia: Estudo \#10.

Os outros estudos irão abordar elementos diversos do jogo, tais como: as mortes do personagem principal (\#8), as texturas utilizadas na representação dos cenários (\#9), os sons do jogo (\#11), os personagens (\#12), uma cena de flutuação presente num dos momentos principais do jogo (\#13), os flashes de cor utilizados para marcar alguns acontecimentos (\#14) e o desenho criado pelas espadas, numa das muitas lutas que o personagem principal precisa vencer. 


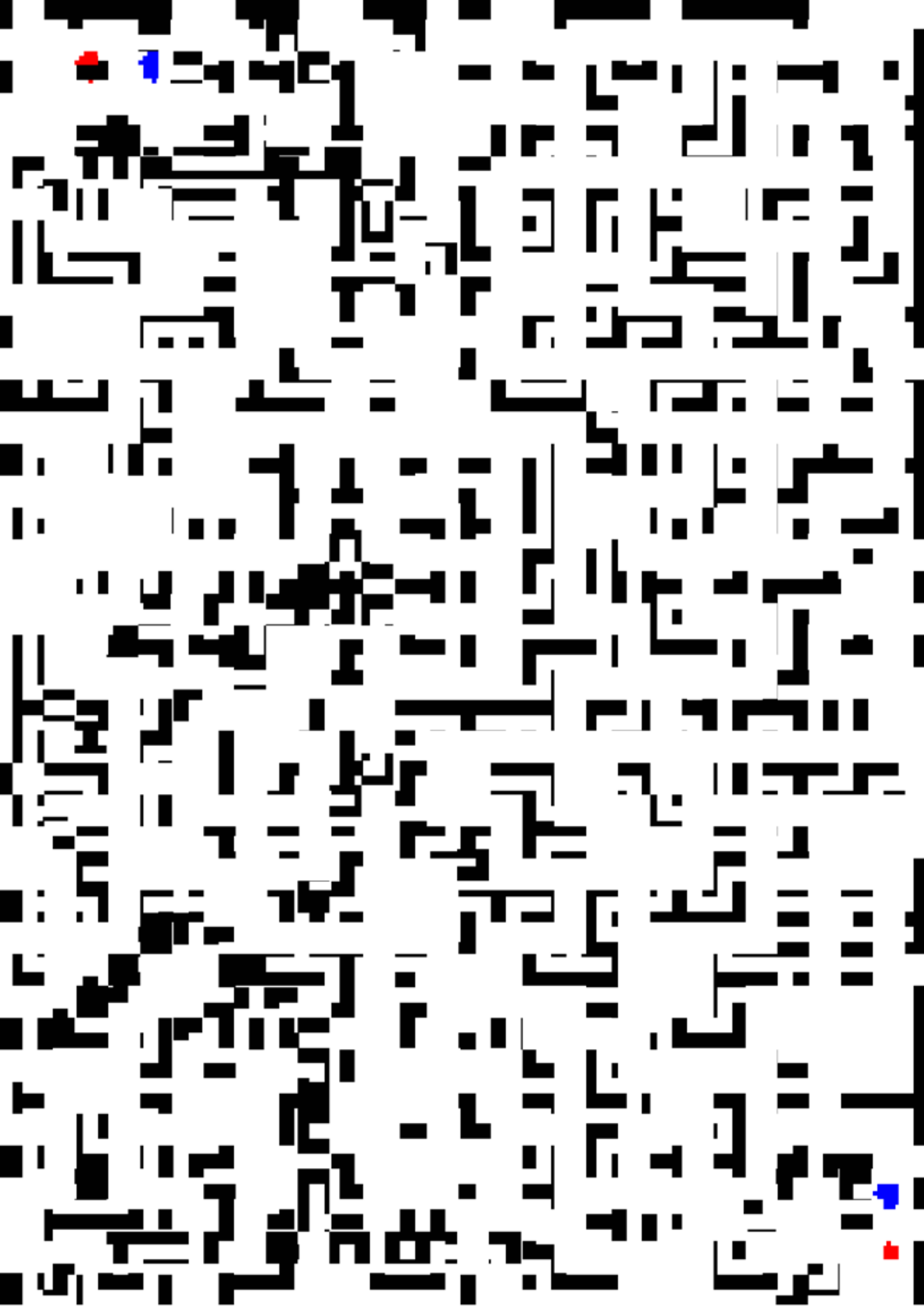





\section{Labirintos Invisíveis}

Labirintos Invisiveis ${ }^{129}$ é um conjunto de dois jogos. O primeiro propõe ao jogador o desafio de escapar de um labirinto que é completamente invisível no início da partida. Um círculo azul representa o jogador e um círculo vermelho indica a saída do labirinto. Cada vez que o jogador move-se dentro do labirinto e esbarra numa parede, esta torna-se visível. Entretanto, como o tempo é limitado (5 minutos), não é possível revelar todo o labirinto; após alguns fracassos, o jogador percebe que é preciso desenvolver alguma forma de estratégia para chegar à saída no tempo disponível. Também não é possível memorizar o desenho do labirinto, já que um labirinto diferente é gerado, aleatoriamente, a cada partida.
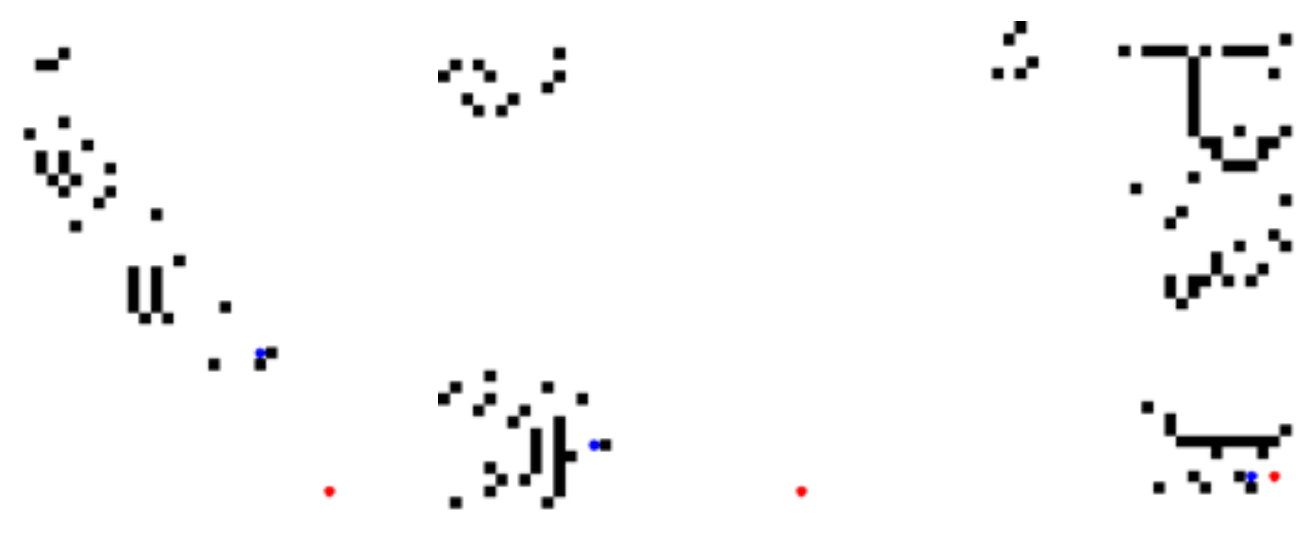

Ilustração 77. Imagens de Labirintos Invisiveis \#1.

Já em Labirintos Invisiveis \#2, o labirinto é visível no início da partida mas, a cada segundo, algumas de suas paredes são apagadas. Porém, apesar de não serem mais visíveis, elas continuam impedindo a passagem do jogador. Assim, o jogo torna-se mais difícil ao longo do tempo, já que o jogador não vê mais quais são os obstáculos no caminho em direção à saída e é obrigado a deslocarme por tentativa e erro.

129 http://www.andreithomaz.com/arte/labirintos invisiveis 

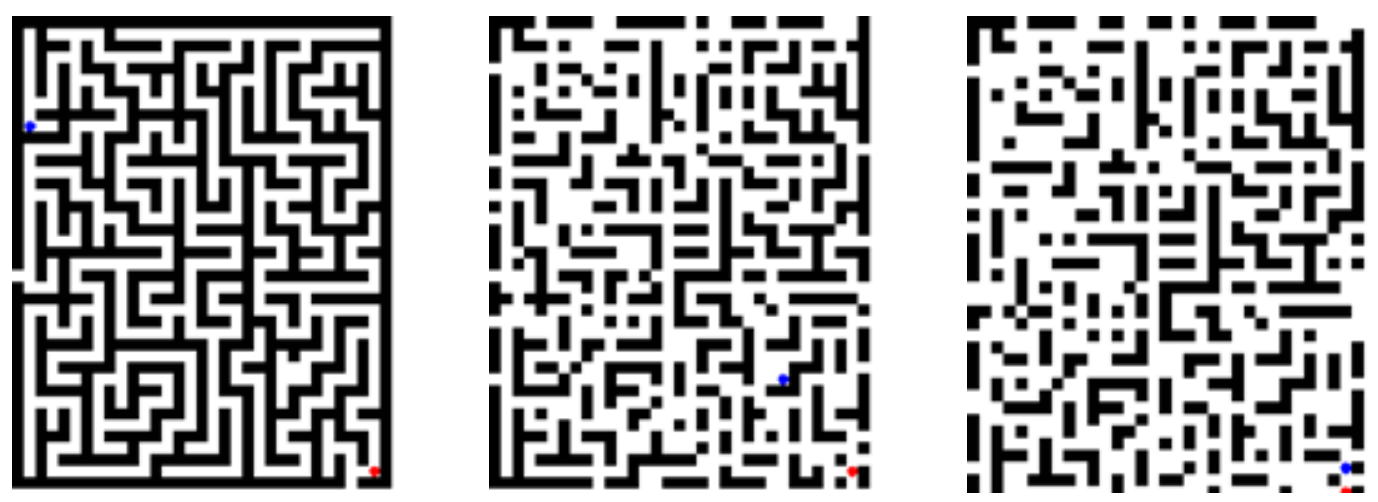

Ilustração 78. Imagens de Labirintos Invisiveis \#2.

Labirintos Invisiveis \#2 coloca o jogador numa situação em que agir rápido é fundamental para a vitória. Nos primeiros minutos, ele precisa escolher se tenta locomover-se o mais rápido possível, ou se estuda o desenho do labirinto, para conseguir deslocar-se quando este já estiver com boa parte de seu traçado apagado. Ao contrário de Labirintos Invisiveis \#1, que se torna mais fácil à medida que o tempo passa - e onde o inimigo do jogador é o tempo que se esgota -, em Labirintos Invisiveis \#2, ter mais tempo para concluir o jogo ajudaria pouco o jogador. Não é mais o limite temporal que precisa ser vencido, mas sim a dificuldade em memorizar o labirinto, tal como exibido no início de cada partida.

Labirintos Invisiveis é o nosso segundo trabalho que lida com a idéia de um labirinto que não pode ser visto, a qual encontramos pela primeira vez no conto $O s$ dois reis e os dois labirintos, de Borges. Neste conto, um labirinto é construído por um rei da Babilônia, sendo de tal complexidade "que os varões mais prudentes não se aventuravam a entrar, e os que entravam se perdiam" (BORGES, 2008b, p. 122). Ao receber a visita de um rei árabe, o rei babilônico faz com que este entre no labirinto e se perca.

Então implorou socorro divino e deu com a porta. Seus lábios não proferiram queixa alguma, mas disse ao rei da Babilônia que ele na Arábia também tinha um labirinto que, se Deus fosse servido, lhe daria a conhecer algum dia. Depois voltou à Arábia, reuniu seus capitães e alcaides e devastou os reinos da Babilônia com tamanha boa sorte que arrasou seus castelos, dizimou sua gente e aprisionou o próprio rei. Amarrou-o em cima de um camelo veloz e o levou para o deserto. Cavalgaram três dias, e disse-lhe: "Ó rei do tempo e substância e cifra do século!, na Babilônia desejaste que eu me perdesse num labirinto de bronze com muitas escadas, portas e muros; o Poderoso teve por bem que eu agora te mostre o meu, onde não há escadas a subir, nem portas a forçar, nem cansativas galerias a percorrer, nem muros para impedir a passagem".

Logo depois, desamarrou-o e o abandonou no meio do deserto, onde ele morreu de fome e sede. A glória esteja com Aquele que não morre.

(BORGES, 2008b, pp. 122-123) 
Motivados por este conto, realizamos, em 2005, no período que antecedeu a realização deste projeto de mestrado, Labirinto Zero ${ }^{130}$, um jogo onde temos um labirinto tridimensional cujas paredes vão do opaco ao transparente, dificultando a movimentação do jogador. O objetivo do jogo é chegar ao centro do labirinto. Quatro blocos vermelhos, dispostos entre o centro e os limites do labirinto, têm o poder de tornar as paredes visíveis por um determinado período de tempo, sem alteração na transparência. Nestes momentos, o deslocamento do jogador torna-se mais rápido e mais fácil.
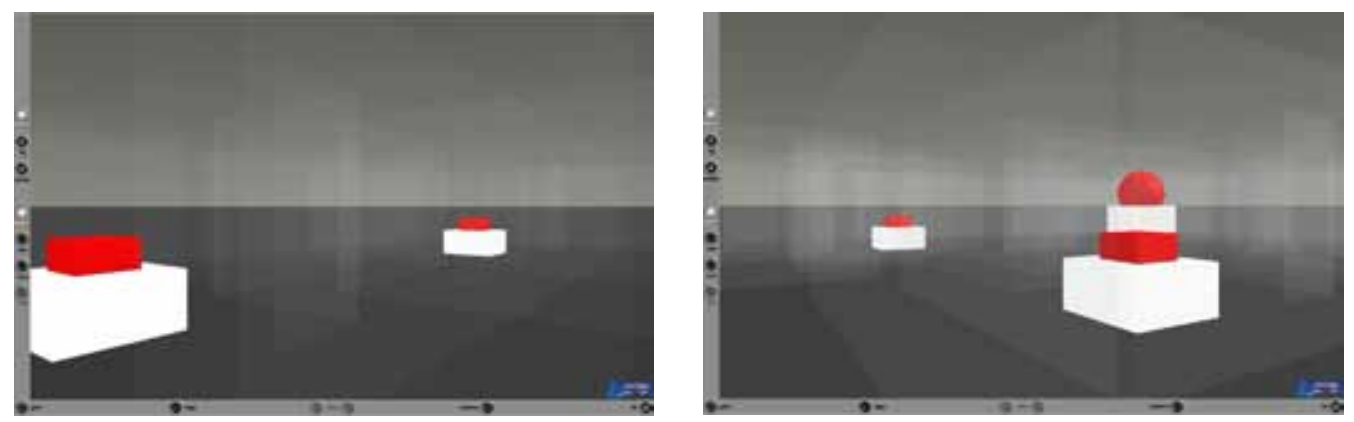

Ilustração 79. Imagens de Labirinto Zero.

Além da influência do conto borgiano, Labirintos Invisiveis também faz referência ao desafio de reconstituir um labirinto que não pode ser percebido pela visão, ao menos não completamente. Buscamos tal imagem num mito da ilha Melanésia dos Malekulas, que é descrito tanto por Leão (2005, p. 87) quanto por Santarcangeli (1974, p. 164).

Existe uma lenda (...) que fala dos perigos que uma alma tem de enfrentar quando desce ao reino dos mortos. Conta a lenda que, ao chegar lá, o viajante encontra-se com uma velha guardiã na porta. A guardiã faz então o desenho de um labirinto na areia e, logo em seguida, apaga partes do traçado com as mãos. Cabe ao candidato a tarefa de refazer o caminho do labirinto para poder entrar na "terra dos mortos". Os que não conseguem refazê-lo são devorados pela mulher.

(LEÃO, 2005, p. 87)

Reunindo os desafios apresentados por Borges e pelo mito da ilha dos Malekulas, criamos as duas mecânicas ${ }^{131}$ de Labirintos Invisiveis. Optamos por expor estas mecânicas da forma mais direta possível, com o objeto de não encobrir o labirinto presente nos jogos. Por isso, não criamos cenários, personagens nem um contexto narrativo para os mesmos. A representação do jogador é a

130 http://www.andreithomaz.com/arte/labirinto zero

131 Conforme definido por Salen e Zimmermman (2004, p. 316). 
mais simples possível, e as informações visuais que ele possui, além do labirinto que ora se revela, ora se desvanece, são apenas o cronômetro e a indicação de onde está a saída. 


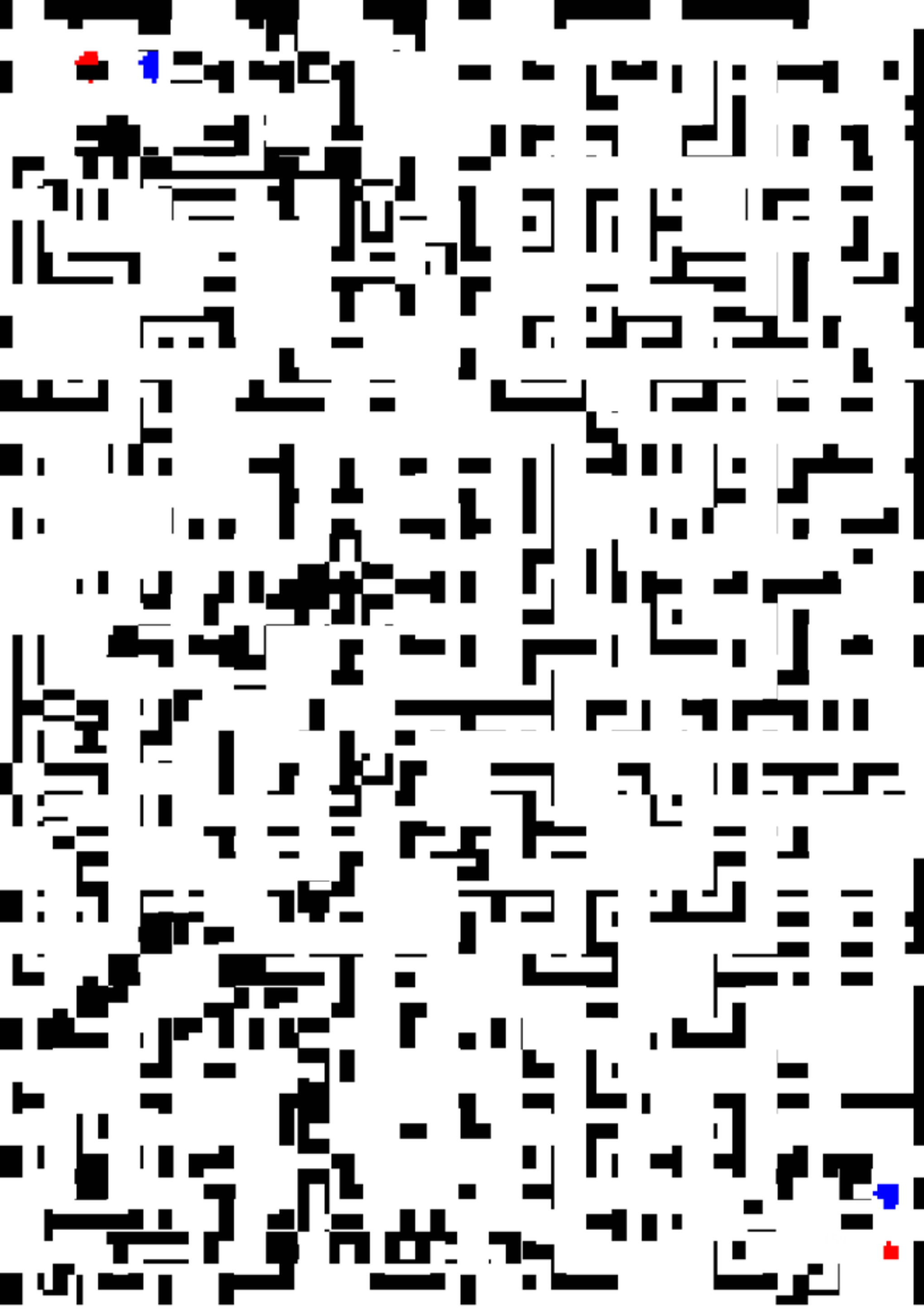





\section{Considerações Finais}

Apesar de sua aparente simplicidade, o último trabalho apresentado nesta dissertação, $L a$ birintos Invisiveis logra, no nosso entendimento, reunir e explicitar idéias e procedimentos que estão presentes ao longo de toda a dissertação. Seja em sua frente teórica, com a leitura da bibliografia de referência e a análise das manifestações do labirinto nos jogos eletrônicos, seja em sua frente artística, em que realizamos os nove trabalhos apresentados aqui, nós nos deparamos com labirintos fugazes, que dificilmente se mostram por inteiro e que precisam ser reconstituídos pelo interator.

Em Cubos de Cor, nós temos um espaço labiríntico que é sugerido ao interator e nunca lhe é dado visualmente. Em First Person Movements, percorremos os corredores dos first person shooters, onde, tal como descreve Rosensthiel (1988b), é preciso agir a partir de informações locais. Apenas com tempo e esforço conseguimos esboçar alguma imagem global do espaço do jogo.

O espaço urbano, tema de Eclipses, também resiste a uma apreensão global. Como o sabem os habitantes de qualquer metrópole, mapas urbanos sempre envolvem algum grau de abstração. Mesmo que alguns incluam informações como sentido do trânsito nas ruas e os meios de transporte presentes em cada área da cidade, apenas a vivência dos espaços representados nos trará a segurança de que somos capazes de compreender o mapa e utilizá-lo como instrumento de orientação, de modo efetivo.

Por sua vez, o labirinto dos possíveis desdobramentos, seja de uma partida de xadrez, de um livro ou do próprio futuro, tende ao infinito, também dificultando a sua compreensão. Ou então... ${ }^{132}$ é a frase que coloca em jogo novas possibilidades, para as quais preveremos as conseqüências e, numa seqüência que poderia ser estendida indefinidamente, as conseqüências das conseqüências. Nos referimos, obviamente, ao trabalho $O$ tabuleiro dos jogos que se bifurcam, e àqueles que se deixaram seduzir pelo exercício das bifurcações sucessivas: Borges, Duchamp e Resnais.

Talvez seja mais difícil perceber como o labirinto se manifesta em Somewhere in Time. Temos uma espacialização da dimensão temporal do filme - a grade com as combinações de horas, minutos e segundos é um tabuleiro de tempo - mas os fios narrativos que percorrem a grade, e que são

132 “Ou então...” é a sentença que marca a apresentação de um novo desdobramento possível para a(s) narrativa(s) de Smoking / No Smoking. Para maiores informações sobre o filme, ver as referências citadas a partir da página 111. 
dissolvidos por ela, são apenas insinuados pelo trabalho. É a nossa mente quem se encarregará de reuni-los, de imaginar contextos e de trazer recordações relacionadas aos fragmentos de legendas que são exibidos. Assumindo O jardim de veredas que se bifurcam como o elo entre $O$ tabuleiro dos jogos que se bifurcam e Somewhere in Time, percebemos que eles são a face e o verso (para usar uma expressão tão cara a Borges) da mesma moeda. Em O tabuleiro... temos as bifurcações sucessivas; em Somewhere in Time, temos a coexistência temporal de todos os tempos (a pululação dos inúmeros futuros, de acordo com as palavras de Borges [2008a, p. 90]), aqui na forma de filmes.

Retornamos à compreensão e ao mapeamento do espaço do jogo em alguns dos estudos do jogo Prince of Persia, onde temos duas formas de visualizar o espaço que nunca são dadas ao jogador. Tanto a planta da fase em que o jogador se encontra quanto o conhecimento do que nos espera nas telas seguintes serão construções mentais, elaboradas a partir da experiência do jogar.

Não é à toa que o único trabalho no qual não percebemos a presença de labirintos são os estudos realizados a partir do jogo Tetris. Entendemos, entretanto, que eles, assim como a primeira parte de Somewhere in Time, enfatizam uma estrutura que pode ser vista como um dos principais contrapontos ao labirinto, e que está presente, de forma oculta, em muitos dos jogos que analisamos: a grade $^{133}$. Estrutura que está presente na gênese dos labirintos por nós criados, com o uso de papéis milimetrados e quadriculados, ambos dotados de grades.

Ao reconhecer algumas das questões que atravessam este trabalho, sentimos a necessidade de buscar as origens desta concepção do labirinto como sendo um espaço que é construído gradualmente pelo sujeito e que, ao mesmo tempo, escapa à uma apreensão global. Neste sentido, não podemos subestimar a nossa dívida com as idéias apresentadas por Omar Calabrese e pelos autores (entre os quais se sobressai Pierre Rosensthiel), obras e artistas por ele citados em dois dos capítulos de A Idade Neobarroca (CALABRESE, 1987): Nó e Labirinto e Pormenor e Fragmento. Outro autor fundamental é Jorge Luis Borges, cujos inúmeras caracterizações do labirinto permeiam todo este trabalho.

Ao apontarmos para o esforço de construir labirintos, exigido de nosso interator, estamos também evidenciando como este trabalho se insere no universo do jogo. O que faz com que uma determinada configuração de peças brancas e pretas, num tabuleiro de 8 x 8 casas, seja vista como "praticamente empatada" ou "situação francamente favorável às brancas", se não um raciocínio,

133 A contraposição entre a grade e o labirinto certamente será assunto de trabalhos futuros. 
realizado a partir da visão do tabuleiro e do conhecimento das regras do jogo? Mesmo nos jogos eletrônicos, onde parte do esforço de avaliar os resultados obtidos pelo jogador é assumido pela máquina, o jogador precisa fazer a sua parte, analisando as imagens e outras informações que lhe são dadas. Assim como a obra de arte precisa de um esforço do espectador para existir, tal como Duchamp coloca em $O$ ato criativo (1996, p. 819), o jogo também o faz em relação ao jogador.

Desta forma, retornamos ao nosso primeiro trabalho apresentado nesta dissertação, Para desenhar com os olhos / Para percorrer com os olhos. Apesar de, nele, o desenho do labirinto de Chartres estar completamente visível, o espectador - ainda assim - precisa mobilizar o seu olhar para compreender que o caminho percorrido pelo pequeno ponto preto é semelhante ao traçado do labirinto. Nenhum elemento é escondido do espectador neste trabalho. Ao mesmo tempo, ele "está completamente dentro da massa cinzenta" ${ }^{134}$.

134 Duchamp em entrevista a Pierre Cabanne (2002, p. 28). 



\section{Referências Bibliográficas:}

\section{Livros}

ALBERTI, Leon Battista. Da Pintura. Campinas: Editora da Unicamp, 1999.

ASSIS, Jesus de Paula. Artes do Videogame. Conceitos e Técnicas. São Paulo: Alemeda, 2007.

ATKINS, Barry. More than a game. Manchester, Nova Iorque: Manchester University Press, 2003.

BITTANTI, Matteo; QUARANTA, Domenico. GameScenes: Art in the Age of Videogames. Milão: Johan \& Levi Editore, 2006.

BLAIS, Joline; IPPOLITO, Jon. At the Edge of Art. Londres: Thames and Hudson, 2006.

BOGOST, Ian. An approach to videogame criticism. Cambridge, Massachussets; London The MIT Press, 2006.

BOLTER, Jay; GROMALA, Diane. Windows and mirrors. Interaction design, digital art, and the myth of transparency. Cambridge, Massachussets; London - The MIT Press, 2003.

BOLTER, Jay; GRUSIN, Richard. Remediation. Understanding New Media. Cambridge, Massachussets; London - The MIT Press, 1999.

BORGES, Jorge Luis. El Aleph. Madrid Alianza, 2004.

_. El Libro de Arena. Buenos Aires: Emecé Editores, 2005.

_. Ficciones. Alianza: Madrid, 2004.

_. Ficções. Companhia das Letras: São Paulo, 2008.

O Aleph. Companhia das Letras: São Paulo, 2008.

BURNHAM, Van. Supercade. A Visual History of the Videogame Age 1971-1984. Cambridge, Massachussets: The MIT Press, 2001.

CABANNE, Pierre. Marcel Duchamp: Engenheiro do Tempo Perdido. São Paulo : Perspectiva, 2002.

CALABRESE, Omar. A Idade Neobarroca. Lisboa: Edições 70, 1987.

CHEVALIER, Jean. Dicionário de Símbolos. Rio de Janeiro: José Olympio, 2003.

CLARKE, Andy; MITCHELL, Grethe. Videogames and art. Bristol, Chicago: Intellect Books, 2006. 
COMPTON, Shanna (ed.). Gamers - Writers, Artists and Programmers on the Pleasures of Pixels. Nova Iorque: Soft Skull Press, 2004.

COUCHOT, Edmont. A Tecnologia na Arte. Editora da UFRGS: Porto Alegre, 2003.

D’AGOSTINI, Orfeu Gilberto. Xadrez Básico. São Paulo: Ediouro, 2002.

DEMARIA, Russel; WILSON, Johnny L. High Score!: The Illustrated History of Electronic

Games. New York: McGraw-Hill Osborne Media, 2003.

DIDI-HUBERMAN, Georges. O que vemos, que nos olha. São Paulo: Editora 34, 1998.

ECO, Umberto. Obra Aberta. São Paulo: Perspectiva, 2003.

FICACCI, Luigi. Piranesi. Água-Fortes. Köln : Taschen, 2006.

FISHER, Adrian. The Amazing book of mazes. New York : Harry N. Abrams, 2006.

GALLOWAY, Alexander. Gaming - Essays on Algorithmic Culture. Minneapolis; London University of Minnesota Press. 2006.

GOSCIOLA, Vicente. Roteiro para as novas mídias - do game à TV interativa. São Paulo: Senac, 2003.

GRAU, Cristina. Borges y la Arquitectura. Madri: Cátedra, 1997.

GRAU, Oliver. Virtual Art - From Illusion to Immersion. Cambridge, Massachussets; London - The MIT Press, 2003.

(ed.). Media art histories. Cambridge, Massachussets; London - The MIT Press, 2006.

GREENE, Rachel. Internet Art. New York: Thames \& Hudson, 2004.

HOCKE, Gustav R. Maneirismo : O Mundo como labirinto. São Paulo: Perspectiva. 2005.

HUIZINGA, Johan. Homo Ludens: o jogo como elemento da cultura. São Paulo: Perspectiva, 2005.

KENT, Steve. The Ultimate History of Video Games: From Pong to Pokemon - The Story Behind the Craze That Touched Our Lives and Changed the World. New York: Three Rivers Press, 2001.

KERN, Hermann. Through the Labyrinth. Munique, Londres, Nova Iorque: Prestel, 2000.

LANDOW, George. Hypertext 2.0. The convergence of contemporary critical theory and technology. Baltimore, London: The Johns Hopkins University Press, 1997.

LEÃO, Lucia. A Estética do Labirinto. São Paulo: Anhembi Morumbi, 2002. 
(org). INTERLAB - Labirintos do Pensamento Contemporâneo. São Paulo: Iluminuras, 2002.

O Labirinto da Hipermídia. Arquitetura e navegação no ciberespaço. São Paulo: Iluminuras, 2005.

LYNCH, Kevin. A Imagem da Cidade. Martins Fontes: São Paulo, 1988.

MACHADO, Arlindo. Máquina e Imaginário: O Desafio das Poéticas Tecnológicas. São Paulo: Edusp, 2001.

_. Pré-cinemas \& Pós cinemas. Campinas, SP: Papirus, 2002.

_. O quarto iconoclasmo e outros ensaios hereges. Rio de Janeiro : Marca d'Água, 2001.

_. O sujeito na tela. Modos de enunciação no cinema e no ciberespaço. São Paulo: Paulus, 2007.

Arte e mídia. Rio de Janeiro : Jorge Zahar Editor, 2007.

MANOVICH, Lev. The Language of New Media. Cambridge, Massachussets; London: The MIT Press, 2001.

MATTHEWS, W. H. Mazes \& Labyrinths - Their History \& Development. Nova Iorque: Dover Publications, 1970.

MOLES, Abraham. Criação Científica. São Paulo: Perspectiva, 1971.

MONTFORT, Nick. Twisty little passages. An approach to interactive fiction. Cambridge, Massachussets - London, England: The MIT Press, 2004.

MURRAY, Janet. Hamlet no Holodeck - o futuro da narrativa no ciberespaço. São Paulo: Editora Unesp, Itaú Cultural: 2003.

PANOFSKY, Erwin. A Perspectiva como Forma Simbólica. Lisboa: Edições 70, 1999.

PARENTE, André (org.). Imagem-máquina. A era das tecnologias do virtual. São Paulo : Editora 34, 1993.

PLAZA, Julio; TAVARES, Monica. Os processos criativos com os meios eletrônicos: poéticas digitais. São Paulo: Hucitec, 1998.

PRADO, Gilbertto. Arte telemática : dos intercâmbios pontuais aos ambientes virtuais multiusuário. São Paulo: Itaú Cultural, 2003.

RAESSENS, Joost, GOLDSTEIN, Jeffrey. Handbook of Computer Game Studies. Cambridge, 
Massachussets; London: The MIT Press, 2005.

ROLLINGS, Andrew; ADAMS, Ernest. Andrew Rollings and Ernest Adams on game design. Berkeley: New Riders, 2003.

SALEN, Katie; ZIMMERMAN, Eric. Rules of Play: Game Design Fundamentals. Massachussets; London: The MIT Press, 2004.

SALEN, Katie; ZIMMERMAN, Eric (ed). The Game Design Reader - A Rules of Play Anthology. Massachussets; London: The MIT Press, 2006.

SANTARCANGELI, Paolo. Le livre des labyrinthes: histoire d'un mythe et d'un symbole. Paris: Gallimard, 1974.

TRIBE, Mark; JANA, Reena. New Media Art. Los Angeles: Taschen, 2006.

VENTURELLI, Suzete. Arte: espaço_tempo_imagem. Brasília: Editora Universidade de Brasília, 2004.

WARDRIP-FRUIN, Noah; HARRIGAN, Pat (ed.). First-Person. New Media as Story, Performance, and Game. Cambridge, Massachussets - London: The MIT Press, 2004.

WOLF, Mark (ed). The Medium of the Video Game. Austin, EUA: University of Texas Press, 2002.

; PERRON, Bernard (ed.). The video game theory reader. New York: Routledge, 2003.

ZAMBONI, Silvio. A pesquisa em arte. Um paralelo entre arte e ciência. Campinas, SP: Autores Associados, 2006.

\section{Teses e Dissertações}

EICHEMBERG, Aleph Teruya. A experiência do tempo morto no cinema e nos "games". 2005. 94f. Mestrado - Pontificia Universidade Católica de São Paulo, São Paulo, 2005.

JUUL, Jesper. A clash between game and narrative - a thesis on computer games and interactive fiction. 1999. 95f. Mestrado - Institute of Nordic Language and Literature, University of Copenhagen, Copenhagen, 1999.

LEITÃO, Luciana Engelsdorff. Ludo-poética : uma proposta de abordagem da arte contemporanea sob o enfoque do jogo. Porto Alegre : Dissertação de Mestrado PPGAV - UFRGS, 1997. 
SPINELLI, Egle Müller. Estudos cronotópicos em narrativas audiovisuais. 2005. 211f. Doutorado - Escola de Comunicação e Artes, Universidade de São Paulo, São Paulo, 2005.

STALKER, Phillipa Jane. Gaming in Art: a case study of two examples of the artistica appropriation of computer games and the mapping of historical trajectories of 'art games' versus mainstream computer games. 2005. 97p. Dissertação (Master of Fine Arts) - University of the Witwatersrand, Johannesburg, 1995. Disponível via WWW url http://www.selectparks.net/ dl/PippaStalker_GamingInArt.pdf. Acesso em 18/03/2008.

\section{Filmes}

CORRA Lola, Corra. Direção: Tom Tykwer. Produção: Stefan Arndt. Intérpretes: Franka Potente, Moritz Bleibfreu, Herbert Knaup, Nina Petri, Armi Rohde, Joachim Król, Ludger Pistor e Julia Lindig. Roteiro: Tom Tykwer. X-Filme Creative Pool / Westdeutscher Rundfunk / German Independents / Arte / BavariaFilm, 1998. 81 min., son., colorido.

CUBO. Direção: Vincenzo Natali. Produção: Mehra Meh. Intérpretes: Nicole DeBoer, Nicky Guadagni, David Hewlett, Andrew Miller, Julian Richings, Waynie Robson e Maurice Dean Wint. Roteiro: Andre Buelic, Vincenzo Natali e Graeme Manson. Toronto : Cube Libre et ali, 1997. 1 DVD, $90 \mathrm{~min}$, son., color., $35 \mathrm{~mm}$.

FEITIÇO do Tempo. Direção: Harold Ramis. Produção: Trevor Albert e Harold Ramis. Intérpretes: Bill Murray, Andie MacDowell, Chris Elliott, Stephen Tobolowsky e Brian Doyle-Murray. Roteiro: Danny Rubin e Harold Ramis. Columbia Pictures, 1993. 101 min., son., colorido.

LABIRINTO. A Magia do Tempo. Direção: Jim Henson. Produção: George Lucas. Intérpretes: David Bowie, Jennifer Connelly e Toby Froud. Roteiro: Terry Jones. Inglaterra / Estados Unidos : Labyrinth Enterprises, 1986. 1 DVD, 101min, son., color., 35 mm.

O ILUMINADO. Direção: Stanley Kubrick. Produção: Stanley Kubrick. Intérpretes: Jack Nicholson, Shelley Duvall, Danny Lloyd e Scatman Crothers. Roteiro: Stanley Kubrick e Diane Johnson. Inglaterra / Estados Unidos : Hawk Films, 1980. 1 DVD, 120 min, son., color., 35mm.

RASHOMON. Direção: Akira Kurosawa. Produção: Jingo Minoru. Intérpretes: Toshiro Mifune, Machiko Kyo, Masayuki Shimura, Minoru Chiaki, Kichijiro Ueda, Daisuke Kato e Fumiko Homma. Roteiro: Akira Kurosawa e Shinobu Hashimoto. Daiei Motion Picture Company, 1950. 88 
min., son., preto e branco.

SMOKING / No Smoking. Direção: Alain Resnais. Produção: Bruno Pésery e Michel Seydoux. Intérpretes: Pierre Arditi e Sabine Azéma. Alia Film, 1993. 298 min. (2 partes), son., colorido. SOMEWHERE in Time. Direção: Jeannot Szwarc. Produção: Stephen Deutsch e Ray Stark. Intérpretes: Christopher Reeve, Jane Seymour, Christopher Plummer, Teresa Wright e Bill Erwin. Universal Pictures, 1980. 103 min.

\section{Artigos em Periódicos, Sites e Capítulos de Livros}

AARSETH, Espen. Aporia and Epiphany in Doom and The Speaking Clock - The Temporality of Ergodic Art. In: RYAN, Marie-Laure (ed). Cyberspace Textuality - Computer Technology and Literary Theory. Bloomington and Indianapolis: Indiana University Press, 1999. pp. 31-41.

ADAMS, Ernest. The role of Architecture in Videogames. Disponível online em http://www. gamasutra.com/features/20021009/adams_01.htm. Acessado em 26/02/2008.

ADVENTURE (Atari 2600). Disponível via WWW url

http://en.wikipedia.org/wiki/Adventure_\%28Atari_2600\%29. Acessado em 03/12/2006.

ADVENTURE Game. Disponível via WWW url http://en.wikipedia.org/wiki/Adventure_game. Acessado em 01/05/2006.

AFTER Burner. Disponível via WWW url http://www.klov.com/game_detail.php?letter=A\&game_id=6821. Acesso em 07/12/2006.

AFTER Burner II. Disponível via WWW url http://www.klov.com/game_detail.php?game_id=6822\&letter=A. Acesso em 07/12/2006. ALBERS, Josef. On my Homage to the Square. In: Stiles, Kristine. Theories and documents of contemporary art : a sourcebook of artists' writings. Berkeley: University of California Press, 1996. p. 107-108.

. The Origin of Art. In: Stiles, Kristine. Theories and documents of contemporary art : a sourcebook of artists' writings. Berkeley: University of California Press, 1996. p. 107.

AMAZING Maze. Disponível via WWW url

http://www.klov.com/game_detail.php?letter=A\&game_id=6875. Acessado em 28/11/2006.

ASSIS, Jesus de Paula. Roteiro em ambientes virtuais interativos. Cadernos da Pós Graduação. v. 
3, n. 1. Campinas: UNICAMP, 1999. p. 93-110.

BRANDÃO, Junito de Souza. Dos Jônios à Ilha de Creta. In: __, Mitologia Grega. Petrópolis : Editora Vozes, 5a ed, 1989. p. 49-66.

CANNON, Rebecca. An introduction to game mod art. Disponível via WWW em http://www. beepkeeper.com/rebecca/?2003:Playthings. Visitado em 18/03/2008.

CLONINGER, Curt. Eternity in an instant: the moving images of David Crawford. Disponível via WWW em http://www.lab404.com/articles/sms/. Escrito em 2005, acessado em 07/05/2008. CRAWFORD, David. Stop Motion Studies. Disponível via WWW em http://www.stopmotionstudies.net/. Acessado em 07/05/2008.

DARK Chambers. Disponível via WWW url http://www.mobygames.com/game/atari-7800/dark-chambers. Acessado em 02/12/2006.

DEFENDER. Disponível via WWW url http://en.wikipedia.org/wiki/Defender_\%28game\%29. Acesso em 30/11/2006.

DUCHAMP, Marcel. The Creative Act. In: Stiles, Kristine. Theories and documents of contemporary art : a sourcebook of artists' writings. Berkeley: University of California Press, 1996. p. 818-819.

ENDURO. Disponível via WWW url http:/ / en.wikipedia.org/wiki/Enduro_\%28video_game\%29. Acesso em 07/12/2006.

ESKELINEN, Markku. The Gaming Situation. Disponível via WWW url http://gamestudies. org/0101/eskelinen/. Acesso em 14/01/2009.

FEATHERSTONE, Mark. Cracking Cube: Cryptology And Ichnography. Disponível via WWW url http://www.ctheory.net/articles.aspx?id=125. Acesso em 23/05/2007.

GAMESHOW. Disponível via WWW url

http://www.massmoca.org/visual_arts/past_exhibitions/visual_arts_past_2001.htm. Acesso em $31 / 05 / 2006$.

GERNSHEIM, Helmut e GERNSHEIM, Alison. Fotografia de movimiento. In: Historia gráfica de la fotografía. Barcelona : Omega, 1966. pp. 153-160.

GODOY-DE-SOUZA, Hélio Augusto. Marey e a Visibilidade do Invisível. Campo Grande : XXIV Congresso Brasileiro de Comunicação, 2001. 
GOTCHA.

Disponível

via

WWW

url

http://www.klov.com/game_detail.php?letter=G\&game_id=7985. Acessado em 28/11/2006.

GREENBERG, Clement. Modernist Painting. In: HARRISON, Charles; WOOD, Paul (ed.). Art

in Theory. 1900-1990. An anthology of changing ideas. Oxford, Inglaterra; Cambridge, EUA :

Blackwell, 1992. pp. 754-760.

HOGAN'S Alley. Disponível via WWW em http://en.wikipedia.org/wiki/Hogan's_Alley_(arca-

de_game), Visitado em 16/03/2008.

HOOPER, Simon. Pacman breaks out of the arcade. Disponível via WWW url

http://www.cnn.com/2004/TECH/11/16/explorers.pacman/. Acesso em 19/02/2007.

HUMAN PACMAN. Disponível via WWW url

http://www.mixedreality.nus.edu.sg/index.php?option=com_content\&task=view\&id=42\&Item

id=74. Acesso em 19/02/2007.

HUNGER, Francis. Perspective Engines - An interview with JODI by Francis Hunger. 2004.

Disponível via WWW url http://www.hgb-leipzig.de/ francis/irmielin/writings/jodi_games.pdf.

Acesso em 13/05/2007.

JAYCOX, Bryan. 3D Immersive Virtual Environment as an Independent Medium. Disponível via

WWW url

http://www.bryanjaycox.com/portfolio/frame_pages/display_window_pages/3d_medium.htm.

Acessado em 18/02/2007.

KNIGHT, Will. Human PacMan hits real city streets. Disponível via WWW url http://www.newscientist.com/article.ns?id=dn6689. Acesso em 19/02/2007.

MACHADO, Arlindo. Hipermídia: o labirinto como metáfora. In: DOMINGUES, Diana. A arte

no século XXI: a humanização das tecnologias. São Paulo : UNESP, 1997. pp. 144-154.

MACHADO, Arlindo. Regimes de Imersão e Modos de Agenciamento. In: Maria Beatriz de Medeiros. (Org.). A Arte Pesquisa. Brasília: Universidade de Brasilía, 2003, v. 1, p. 173-181.

MAKURKIEWICZ, Antoni. Algoritmo. In: Enciclopédia Einaudi. Lisboa : Imprensa NacionalCasa da Moeda, 1984. Vol. XV, pp. 216-226.

MANOVICH, Lev. The Poetics of Augmented Space: Learning from Prada (2002, revisado em 2005). Disponível via WWW url http://www.manovich.net/DOCS/augmented_space.dod. Aces- 
sado em 19/02/2007.

MARINER. Spy vs Spy. FAQ 2.0. Disponível via WWW url http://www.neshq.com/games/s/spyvsspy/spyvspy-faq1.txt. Acessado em 07/12/2006.

MARTINS, Ivan. Labirintos no Jardim. In: Superinteressante Especial Jogos, Ano 6, No 1. São Paulo: Ed. Abril, 1992.

MMORPG. Disponível via WWW url http://pt.wikipedia.org/wiki/Mmorpg. Acessado em 25/01/2009.

PACMANHATTAN. Disponível via WWW url http://www.pacmanhattan.com/. Acesso em $19 / 02 / 2007$.

PENNY, Simon. Virtual Reality as the End of the Enlightenment Project. Disponível via WWW url http://ace.uci.edu/penny/texts/enlightenment.htm. Acesso em 14/01/2009.

PETITOT, Jean. Centrado/acentrado. In: Enciclopédia Einaudi, v. 13, Lógica-Combinatória. Imprensa Nacional/Casa da Moeda, 1988, pp. 336-93.

. Local/global. In: Enciclopédia Einaudi, v. 4, Local-Global. Imprensa Nacional/Casa da Moeda, 1988, pp. 11-71.

PRINCE of Persia. Disponível via WWW url http://en.wikipedia.org/wiki/Prince_of_Persia. Acessado em 03/12/2006.

R-TYPE. Disponível via WWW url http://en.wikipedia.org/wiki/R-type. Acessado em 05/12/2006.

REGAN, Jim. Smart machines, dumb people. Site reviews ranging from a Java-powered online chess game to the 'worst technical manual ever written'. Disponível via WWW url http://www. csmonitor.com/2004/1202/p25s01-stin.html. Acessado em 06/03/2009.

ROSENSTIEHL, Pierre. Grafo. In: Enciclopédia Einaudi, v. 13, Lógica-Combinatória. Imprensa Nacional/Casa da Moeda, 1988, pp. 196-227.

Labirinto. In: Enciclopédia Einaudi, v. 13, Lógica-Combinatória. Imprensa Nacional/Casa da Moeda, 1988, pp. 246-273.

. Rede. In: Enciclopédia Einaudi, v. 13, Lógica-Combinatória. Imprensa Nacional/Casa da Moeda, 1988, pp. 228-247.

SANDHANA, Lakshmi. PacMan comes to life virtuality. Disponível via WWW url http://news. 
bbc.co.uk/2/hi/technology/4607449.stm. Acessado em 19/02/2007.

SHAHRANI, Sam. A History and Analysis of Level Design in 3D Computer Games. Disponível via WWW url

http://www.samshahrani.com/downloads/A\%20History $\% 20$ and $\% 20$ Analysis $\% 20$ of $\% 20$

Level\%20Design\%20in\%203D\%20Computer\%20Games.pd Acessado em 18/02/2007,

SPY vs. Spy. Disponível via WWW url

http://en.wikipedia.org/wiki/Spy_vs._Spy_\%28computer_game\%29. Acessado em 07/12/2006.

STEWART, Ian. A verdade sobre o Minotauro. In: SCIENTIFIC American Brasil - Matemá-

tica. São Paulo : Duetto, 2008. No 1, 2008. p. 34-39.

S.T.U.N. Runner. Disponível via WWW url

http://www.klov.com/game_detail.php?letter=S\&game_id=9393. Acesso em 07/12/2006.

SUPER Mario Bros. Disponível via WWW url http://en.wikipedia.org/wiki/Super_Mario_Bros.

Acesso em 26/07/2006.

TANK. Disponível via WWW url http://www.klov.com/game_detail.php?letter=T\&game id=12989. Acessado em 28/11/2006.

TODD, Brett. Evidence: The Last Ritual Review. Disponível via WWW url

http://www.gamespot.com/pc/adventure/evidence/review.html?om_act=convert\&om_

clk=gssummary. Publicado em 14/11/2006, acessado em 21/02/2007.

TRIBE, Mark. Game Show: Net Games Now. Disponível via WWW em http://nothing.org/ga-

meshow/. Escrito em 2001, visitado em 17/03/2008.

VISIONS of videogames. In: Idea, no 288, 2001, Tóquio. p. 11-82.

WOLFENSTEIN 3D. Disponível via WWW url http://en.wikipedia.org/wiki/Wolfenstein_3D.

Acesso em 31/05/2006.

ZELDA, The Legend of. Disponível via WWW url

http://en.wikipedia.org/wiki/The_Legend_of_Zelda. Acessado em 03/12/2006.

ZELDA SERIES, The Legend of. Disponível via WWW url

http://en.wikipedia.org/wiki/The_Legend_of_Zelda_\%28series\%29. Acessado em 26/07/2006. 


\section{Sites}

HUNTER, William. The history of video games - from 'pong' to 'pacman'. Disponível via WWW url http://www.designboom.com/eng/education/pong.htm. Visitado em 28/11/2006.

HUNTER, William. The Dot Ears - Videogame History. Disponível via WWW url http://www. emuunlim.com/doteaters/play2sta4.htm. Visitado em 28/11/2006.

KLOV, http://www.klov.com/.

Rhizome, http://www.rhizome.org/.

SCHLEINER, Anne-Marie (org.). Cracking the Maze. Jornal eletrônico SWITCH, edição de julho de 1999. Disponível via WWW url http://switch.sjsu.edu/CrackingtheMaze/. Acessado em 05/08/2007.

Turbulence, http://www.turbulence.org.

Wikipedia, http://wikipedia.org. 


\section{Índice de Ilustrações}

Ilustração 1. PacManDRAW!

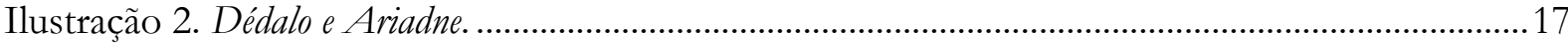

Ilustração 3. Primeira etapa de PacMan e o Minotauro ............................................................................... 17

Ilustração 4. PacMan 1.0, trabalho desenvolvido entre 2002 e 2003..................................................... 18

Ilustração 5. Traçado do labirinto unicursal cretense. .................................................................................. 30

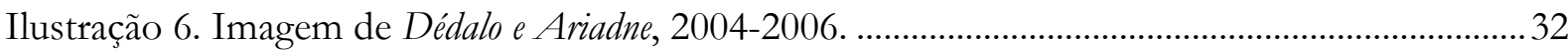

Ilustração 7. Imagens de Para desenhar com os olhos / Para percorrer com os olhos. ................................... 41

Ilustração 8. Um dos labirintos de Maz̧e Craz̧. Jogo sendo executado pelo emulador Stella, em um computador atual.

Ilustração 9. Imagem de Ultratank, rodando sob emulação.

Ilustração 10. Duas imagens de Dig-Dug, versão para console Atari, rodando em emulador. À esquerda, o final de um dos primeiros níveis do jogo, onde resta apenas o personagem do jogador na tela, com os túneis cavados para perseguir seus inimigos, que podem ser vistos na imagem à direita.

Ilustração 11. Imagens de PacManDR AW!.

Ilustração 12. Imagens de PacMan. À esquerda, tela da versão original, em arcade, de PacMan. À direita, versão para console Atari, rodando sob emulação.

Ilustração 13. Imagem de Football, jogo da Atari, rodando sob emulação. Os Xs e Os representam os jogadores dos dois times adversários.

Ilustração 14. Imagens de Super Mario, onde o jogador se movimenta, prioritariamente, para a direita. Jogo rodando sob emulação. .56

Ilustração 15. À esquerda, tela de Defender, versão para Atari 2600, rodando sob emulação, onde podemos perceber a tela de radar, ampliada à direita.

Ilustração 16. Movimento do usuário entre dois espaços, no sentido horizontal: ao deslocar-se um pouco para a esquerda, o usuário (personagem marrom) move-se para outra sala, sem que o jogo "role", de forma contínua, o cenário, de forma a acompanhar o movimento do jogador. É interessante observar que o jogo utiliza a cor das paredes para marcar a mudança de espaço. 58

Ilustração 17. O mundo principal (à esquerda) e dois dos dungeons do primeiro jogo da série de 
Ilustração 18. Imagens de Adventure.

Ilustração 19. Jogador entrando num castelo (à esquerda) e no interior do mesmo (à direita) ......61

Ilustração 20. Um dos mapeamento dos espaços de Adventure

Ilustração 21. Imagens da abertura de Prince of Persia, no qual a narrativa do jogo é apresentada ao jogador

Ilustração 22. Os dois tipos de cenário de Prince of Persia..

Ilustração 23. Imagens de Sonic the Hedgehog, rodando sob emulação.

Ilustração 24. Imagem de R-Type II, rodando sob emulação.

Ilustração 25. Imagens de Enduro, lançado em 1983 pela Activision para a plataforma Atari (EN-

DURO, 2006). O carro branco é o veículo controlado pelo jogador. Jogo rodando sob emulação..

65

Ilustração 26. Imagens de S.T.U.N. Runner. Jogo sendo executado sob emulação. 65

Ilustração 27. Imagens de After Burner II, rodando sob emulação.

Ilustração 28. Telas de Spy vs Spy, versão para NES, rodando sob emulação

Ilustração 29. Duas imagens de Battlezone, onde a mira do tanque indica a presença do jogador no cenário. A seguir, o dano ao tanque do jogador é representado pelas rachaduras no vidro do periscópio. Imagens obtidas através da emulação do jogo original num computador atual. . .70

Ilustração 30. Imagens de Doom....... . .71

Ilustração 31. Dois cenários de Myst 72 Ilustração 32. Enigmas de Myst: à esquerda, temos uma série de botões, cuja configuração exata precisa serencontrada ao longo do cenário.Jáà direita, temos as datas que precisarão serutilizadas no planetário do cenário principal do jogo, para termos acesso a uma das idades de Myst. 72 Ilustração 33. Duas imagens de SimCity 2000. Acima, uma cidade no seu início, basicamente vazia; abaixo, uma cidade superpovoada. Imagens capturadas diretamente do jogo. 73

Ilustração 34. Uma das cenas iniciais de Cubo. 82

Ilustração 35. Outra cena de Cubo, onde podemos ver um dos personagens 82

abrindo a passagem de um cubo para outro. .... 82

Ilustração 36. Josef Albers. Homenagem ao Quadrado, 1961. 84 
Ilustração 37. Josef Albers. Homenagem ao Quadrado, 1968. Fonte das imagens: site da The Josef e Anni Albers Foundation, http://www.albersfoundation.org/. Acesso em 10/05/2008 ................ 84

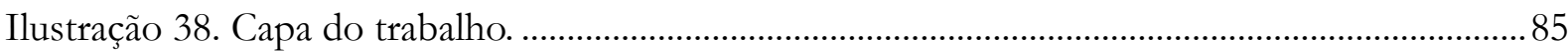

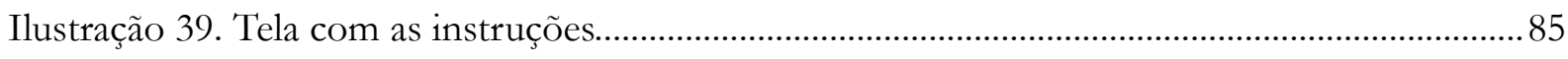

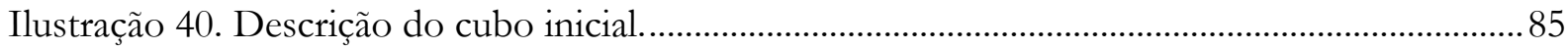

Ilustração 41. Imagem do trabalho após alguns movimentos do espectador...................................... 86

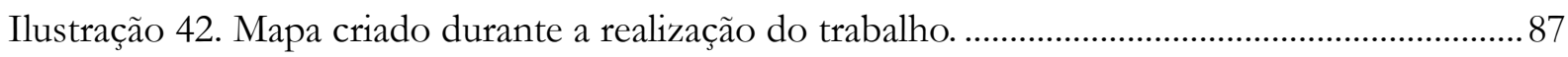

Ilustração 43. Quadros da animação que finaliza Cubos de Cor............................................................ 88

Ilustração 44. À esquerda, descrição do movimento \#1: Percorrer um corredor em L que liga duas salas. À direita, o vídeo com o movimento, em seis velocidades diferentes. ….......................................... 91

Ilustração 45. À esquerda, descrição do movimento \#4: Percorrer um corredor, virar-se no final e ver uma escada. À direita, os vídeos com o movimento. ..................................................................................... 92

Ilustração 46. Homem correndo, vestido de preto e com linhas brancas, Étienne-Jules Marey...................... 93

Ilustração 47. Woman walking downstairs, Eadweard Muybridge........................................................... 93

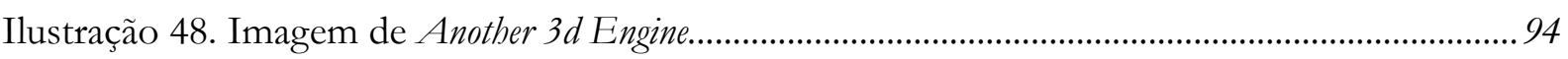

Ilustração 49. Imagem de Prince of Persia: Estudo \#3. .............................................................................. 94

Ilustração 50. Imagens de Stop Motion Studies - Tokyo - Series 8, disponíveis no site do projeto...... 95

Ilustração 51. Mapa que mostra a Rua Mostardeiro na cidade de Porto Alegre, RS........................ 99

Ilustração 52. Mapa que mostra a Rua Mostardeiro na cidade de Porto Velho, RO. ......................100

Ilustração 53. Combinação do mapa com a Rua Mostardeiro em Porto Alegre e em Porto Velho (à esq.). Combinação dos mapas com as ocorrências da Rua Ramiro Barcelos (onze ruas com este nome foram encontradas nas cidades brasileiras, à dir.). ................................................................... 100

Ilustração 54. Álbum de fotografias dos personagens de The Sims 2 2.................................................109

Ilustração 55. Os dois ambientes de O Coz̧inheiro das Almas, já implementados: à esquerda, a garçonnière; à direita, a Escola Normal (atualmente, prédio da Secretaria da Educação, Praça da República, São Paulo). 110

Ilustração 56. Tela de um jogo de xadrez com os "pensamentos” do jogo. 124

Ilustração 57. Thinking Machine 4, instantes após movermos o peão do rei. Alguns movimentos possíveis já são representados na tela 
Ilustração 58. Thinking Machine 4, prestes a jogar após o nosso movimento do peão do rei. Podemos observar que a quantidade de movimentos representados cresceu de forma expressiva, num tempo

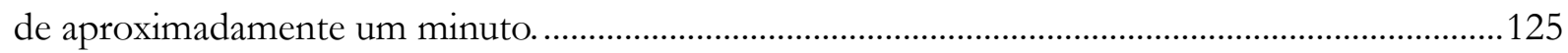
Ilustração 59. O início da primeira versão de O tabuleiro dos jogos que se bifurcam................................129 Ilustração 60. O final da primeira versão de O tabuleiro dos jogos que se bifurcam.................................129 Ilustração 61. Segunda versão de O tabuleiro dos jogos que se bifurcam, onde podemos ver os cálculos em cinza.

A cor do fundo indica que são as pretas que jogam.

Ilustração 62. Aqui, temos o trabalho após o encerramento do jogo, com o De2\# representando o xeque-mate dado pela Dama, e o fundo branco indicando que a partida foi vencida pelas peças brancas. 130

Ilustração 63. Primeira etapa de Somewhere in Time.

Ilustração 64. Segunda etapa do trabalho. 137

Ilustração65. Terceiro momento de Somewhere in Time. Neste trecho, temos uma pista da origem do texto (as legendas são do filme Cidadão Kane)

Ilustração 66. Tela do VisiCalc, primeiro programa de planilha criado para computadores pessoais.

Ilustração 67. Tela do OpenCalc, programa de planilha do pacote OpenOffice, distribuído como software livre. Versão de 2008 141

Ilustração 68. As peças utilizadas por Tetris. 145

Ilustração 69. A mecânica de Tetris: quando a peça verde chegar ao final da tela, ela completa a linha, que desaparecerá.

Ilustração 70. Tetris : Estudo \#1.

Ilustração 71. Tetris : Estudo \#2.

Ilustração 72. Tetris : Estudo \#3.

Ilustração 73. Tetris : Estudo \#4.

Ilustração 74. Imagem de Prince of Persia: Estudo \#2 (à esq.) e Prince of Persia: Estudo \#4 (à dir.).151

Ilustração 75. Imagens de Prince of Persia: Estudo \#7.

Ilustração 76. Imagens de Prince of Persia: Estudo \#10. 


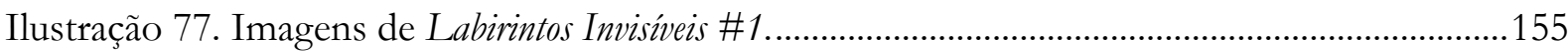

Ilustração 78. Imagens de Labirintos Invisiveis \#2............................................................................156

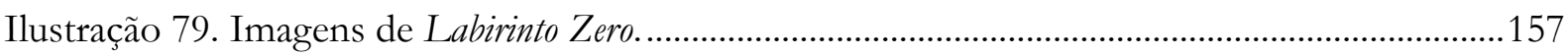




\section{Anexo - Site do Projeto}

No CD em anexo, está disponível o site desta dissertação projeto, em versão executável para computadores PC, equipados com sistema operacional Windows. Caso esteja utilizando outro sistema operacional, ou tenha alguma dificuldade em acessar o conteúdo do CD, por favor, acesse o site do projeto, no endereço www.andreithomaz.com/mestrado/.

Caso o site desta pesquisa não seja aberto, automaticamente, quando o CD for inserido no drive adequado, clique duas vezes sobre o arquivo mestrado.exe para abri-lo. 